\title{
Kenmerken van zorg en kwaliteit van leven bij patiënten met kanker
}

Citation for published version (APA):

Courtens, A. M. (1993). Kenmerken van zorg en kwaliteit van leven bij patiënten met kanker. [Doctoral Thesis, Maastricht University]. Datawyse / Universitaire Pers Maastricht. https://doi.org/10.26481/dis.19930318ac

Document status and date:

Published: 01/01/1993

DOI:

10.26481/dis.19930318ac

Document Version:

Publisher's PDF, also known as Version of record

\section{Please check the document version of this publication:}

- A submitted manuscript is the version of the article upon submission and before peer-review. There can be important differences between the submitted version and the official published version of record.

People interested in the research are advised to contact the author for the final version of the publication, or visit the DOI to the publisher's website.

- The final author version and the galley proof are versions of the publication after peer review.

- The final published version features the final layout of the paper including the volume, issue and page numbers.

Link to publication

\footnotetext{
General rights rights.

- You may freely distribute the URL identifying the publication in the public portal. please follow below link for the End User Agreement:

www.umlib.nl/taverne-license

Take down policy

If you believe that this document breaches copyright please contact us at:

repository@maastrichtuniversity.nl

providing details and we will investigate your claim.
}

Copyright and moral rights for the publications made accessible in the public portal are retained by the authors and/or other copyright owners and it is a condition of accessing publications that users recognise and abide by the legal requirements associated with these

- Users may download and print one copy of any publication from the public portal for the purpose of private study or research.

- You may not further distribute the material or use it for any profit-making activity or commercial gain

If the publication is distributed under the terms of Article $25 \mathrm{fa}$ of the Dutch Copyright Act, indicated by the "Taverne" license above, 
Kenmerken van zorg en kwaliteit van leven bij patiënten met kanker 



\title{
Kenmerken van zorg en kwaliteit van leven bij patiënten met kanker
}

\author{
Proefschrift
}

ter verkrijging van de graad van doctor aan de Rijksuniversiteit Limburg te Maastricht, op gezag van de Rector Magnificus, Prof. Mr. M.J. Cohen, volgens het besluit van het College van Dekanen, in het openbaar te verdedigen op donderdag, 18 maart 1993 om 14.00 uur

door

\section{Anna Maria Courtens}

geboren te Maastricht op 3 februari 1962

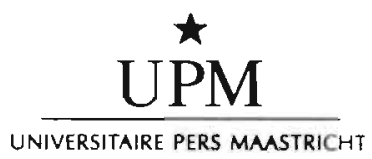




\section{Promotores:}

Prof. dr. H. Philipsen

Prof. dr. H.F.J.M. Crebolder

Co-promotores:

Dr. F.C.J. Stevens

Dr. R.F. van der Grinten

Beoordelingscommissie:

Prof. dr. G.J. Kok (voorzitter)

Dr. J. Bensing, Nivel, Utrecht

Prof. dr. H.J. Dokter, emeritus, Erasmus Universiteit, Rotterdam

Prof. dr. H. Huijer Abu-Saad

Prof. dr. A.C. Nieuwenhuijzen Kruseman

CIP-Gegevens Koninklijke bibliotheek, Den Haag

Courtens, Anna Maria

Kenmerken van zorg en kwaliteit van leven bij patiënten met kanker/ Anna Maria Courtens- Maastricht:

Universitaire Pers Maastricht-Ill.

Proefichrift Maastricht- Met lit.opgave

Met sumenvatting in het Engels.

ISBN 90-5278-002-5

NUGI $756 / 735$

Trefw: kankerpatiēnten

Productie:Datawyse Masastrichi, Ruud Leliveld

Druk: Krips Repro Meppel

Omslag: Ruud Leliveld 


\section{Inhoudsopgave}

1.1 Het onderwerp van dit onderzoek 9

$1.2 \quad$ Kenmerken van zorg 11

1.3 Persoonsgebonden kenmerken in dit onderzoek 12

$1.4 \quad$ Een precisering van de probleemstelling 12

$2 \quad$ Probleemstelling en literatuurstudie 15

2.1 De betekenis van het begrip kwaliteit van leven 15

Kenmerken van de ziekte c.q behandeling en kwaliteit
van leven

$2.3 \quad$ Professionele zorgverlening en sociale steun 23

$2.4 \quad$ Persoonsgebonden kenmerken 34

$\begin{array}{lll}2.5 & \text { Vraagstellingen en verwachtingen } & 38\end{array}$

$3 \quad$ Het onderzoeksontwerp 41

3.1 De onderzoeksopzet 41

3.2 De onderzoekseenheden 42

3.3 Selectie van patiënten 42

$3.4 \quad$ Het onderzoeksprotocol 43

3.5 De verzameling van gegevens 45

3.6 Operationalisatie van de variabelen 45

$3.7 \quad$ Overzicht van de variabelen $\quad 58$ 
4.1 Opbouw van de onderzoeksgroep in Noord-Limburg 61

$4.2 \quad$ Opbouw van de patientengroep in Maastricht 65

4.3 Sociaal-demografische en ziektekenmerken van patiënten 66

$4.4 \quad$ Zorguerleners 68

$\begin{array}{lll}4.5 & \text { Samenvatting en conclusies } & 72\end{array}$

$5 \quad$ Kwaliteit van leven en het beloop daarvan 75

5.1 Gemiddelde waarden op de maten voor kwaliteit van leven 75

$5.2 \quad$ Veranderingen in kwaliteit van leven op individueel niveau 82

5.3 Samenvatting en conclusies $\quad 85$

$6 \quad$ Kenmerken van de ziekte en de behandeling, sociale positie en beheersingsoriëntatie in relatie tot kwaliteit van leven 
9.1 De geselecteerde onafhankelijke variabelen en $\begin{array}{ll}\text { hun onderlinge samenhang } & 125\end{array}$

$\begin{array}{lll}9.2 & \text { De transversale analyses } & 128\end{array}$

9.3 De longitudinale analyses $\quad 132$

9.4 Toepassing van het model op de Maastrichtse groep 136

$\begin{array}{lll}9.5 & \text { Samenvatting } & 138\end{array}$

10 Conclusies en discussie 141

10.1 Evaluatie van het onderzoek 141

$10.2 \quad$ Methodologische problemen $\quad 152$

$10.3 \quad$ Praktische aanbevelingen 155

$\begin{array}{lll}10.4 & \text { Aanbevelingen voor verder onderzoek } & 157\end{array}$

$\begin{array}{lll}10.5 & \text { Slotbeschouwing } & 158\end{array}$

$\begin{array}{ll}\text { Samenvatting } & 161\end{array}$

$\begin{array}{ll}\text { Summary } & 169\end{array}$

$\begin{array}{ll}\text { Literatuurlijst } & 175\end{array}$

$\begin{array}{ll}\text { Bijlagen } & 183\end{array}$

$\begin{array}{ll}\text { Dankwoord } & 195\end{array}$

$\begin{array}{ll}\text { Curriculum vitae } & 197\end{array}$ 



\section{$1 \quad$ Inleiding}

Het hier beschreven onderzoek gaat over de kwaliteit van leven van 79 kankerpatienten in Noord-Limburg en 38 kankerpatiënten uit Maastricht en omgeving. Het betreft een longitudinaal onderzoek waarin patiënten en hun zorgverleners een jaar lang werden gevolgd. Op de eerste plaats wordt een beschrijving gegeven van de ervaren kwaliteit van leven van deze patiënten en de veranderingen die daarin optreden gedurende een jaar. Die veranderingen worden hier ook het beloop van kwaliteit van leven genoemd. Ten tweede richten we ons op de vraag of de ervaren kwaliteit van leven en het beloop daarvan, behalve door ziekte en behandeling, ook wordt beïnvloed door de mate van continuïteit van de professionele zorgverlening, de mate van sociale steun en door enkele persoonsgebonden kenmerken van de patiënten. De veranderingen die in deze kenmerken optraden gedurende het jaar dat de patiënten gevolgd zijn, worden eveneens beschreven.

Kwaliteit van leven en continuïteit van de zorg zijn onderwerpen die 'leven' in de praktijk van de zorgverlening. Dit bleek uit de vraag vanuit het academisch ziekenhuis Maastricht om onderzoek te verrichten naar (het beloop van) kwaliteit van leven bij kankerpatiënten en het verzoek van een geacademiseerd gezondheidscentrum in Venlo om de coördinatie van zorg bij deze patiënten tot onderwerp van studie te maken. Deze vragen werden gecombineerd en vormden de directe aanleiding tot het hier beschreven onderzoek.

\subsection{Het onderwerp van dit onderzoek}

Kanker is een ernstig en omvangrijk gezondheidsprobleem. In Nederland is kanker na hart- en vaatziekten de meest voorkomende doodsoorzaak (Stichting toekomstscenario's Gezondheidszorg, 1987). Het krijgen van kanker is een ingrijpende gebeurtenis. De mededeling dat men kanker heeft, komt bij de meeste mensen hard aan. Men spreekt in de eerste fase van het ziek-zijn wel van een existentiële crisis, die gepaard kan gaan met gevoelens van wanhoop, angst en depressie (Weisman, 1979; Ros, 1990). Kanker is een ziekte die sociale processen, dagelijkse bezigheden en het psychische evenwicht zodanig kan ontregelen dat de kwaliteit van leven wordt aangetast. De mate waarin de ziekte van invloed is op de ervaren kwaliteit van leven 
zall voor een deel afhangen van de diagnose, het stadium van de ziekte en de overlevingsprognose. Maar ook de behandeling die de patiënt krijgt speelt een rol. De behandeling van kanker in het algemeen is nog steeds problematisch: de gemiddelde 5-jaarsoverleving ligt niet hoger dan 40\% (Stichting toekomstscenario's Gezondheidszorg, 1987) en de behandelingen zijn vaak belastend voor de patiënt omdat ze naast kwaadaardig weefsel ook gezonde weefsels aantasten, met alle negatieve gevolgen van dien. Het is aannemelijk dat de invloed van de ziekte en de behandeling op de kwaliteit van het leven verandert gedurende het ziekteproces. In de fase van diagnostiek en behandeling zullen andere problemen een rol spelen dan in de fase van aanpassing aan het leven van alledag, de eventuele terugkeer van de ziekte of in een terminale fase. Bij onderzoek naar kwaliteit van leven bij deze patiëntengroep is het daarom van belang om de patiënt te volgen tijdens het ziekteproces en een langere periode te beschrijven. Tot nu toe is in onderzoek kwaliteit van leven meestal op één tijdstip gemeten. In ons onderzoek geven we een beschrijving van de kwaliteit van het leven van kankerpatiënten gedurende een jaar van het ziekteproces. Dit betreft het eerste doel van dit onderzoek. Het tweede doel van dit onderzoek is inzicht te krijgen in de mate waarin continuïteit van de zorg en sociale steun een rol spelen in de verklaring van verschillen in kwaliteit van leven en het beloop daarvan.

\subsection{Kenmerken van zorg}

Het is evident dat ziektekenmerken en behandeling van invloed zijn op kwaliteit van leven. Het zijn echter niet de enige factoren die van betekenis geacht kunnen worden. In dit onderzoek richten we ons speciaal op die groep factoren die we samenvatten als 'kenmerken van de zorg'.

Op de eerste plaats is kenmerkend voor patiënten met kanker dat naast de behandeling, die vaak gericht is op partieel herstel en verzachten van het lijden, ook andere aspecten van de zorg zoals verpleging, verzorging en begeleiding van belang zijn. Daarnaast treedt door het ziek-zijn niet alleen een zekere mate van disfunctioneren en onwelbevinden op, maar verandert ook iets in de mate waarin de patiënt autonoom kan handelen. De patiënt wordt door het ziek-zijn in toenemende mate afhankelijk van de zorg van anderen. Men spreekt ook wel van een verstoring van de afhankelijkheidsbalans (Wilkin, 1987; De Swaan, 1982; Philipsen, 1988). Die 'anderen' kunnen professionele zorgverleners zijn, maar ook mensen uit de directe omgeving, zoals familie, vrienden en buren of lotgenoten.

Op de derde plaats is kenmerkend dat de ziekte geen incident vormt maar in mindere of meerdere mate chronisch is. $\mathrm{Zij}$ vormt een geïntegreerd bestanddeel van het leven van de patiënt en zijn zogenaamde patiëntencarrière. Als gevolg hiervan is er vaak sprake van langdurige, veranderlijke zorgbehoeften.

Duidelijk wordt dat 'zorg' in de brede zin van het woord een wezenlijk onderdeel vormt van het leven van de patiënt. Het is daarom niet voldoende om bij patiënten met kanker, zorg alleen in medisch-technische zin te beschouwen. De zorg voor kankerpatiënten is immers veel complexer. Daarom wordt in dit onderzoek aandacht besteed aan verschillende aspecten van zorg. 
De zieke zal veelal uit verschillende 'zorgbronnen' putten om aan zijn behoefte aan zorg te kunnen voldoen. In dit onderzoek wordt een onderscheid gemaakt tussen: zorgverlening gegeven door professionele zorgverleners en sociale steun gegeven door mensen uit het sociale netwerk van de patiënt. Op deze twee typen zorg wordt hierna dieper ingegaan.

\subsubsection{Professionele zorgverlening}

Professionele zorgverlening is intentioneel, beroepsmatig, weloverwogen en veronderstelt bepaalde vaardigheden en kennis (Orem, 1985; Philipsen, 1988). De patiënt en de mensen uit zijn directe omgeving komen na de diagnose kanker in ieder geval in aanraking met professionele zorgverlening. Men krijgt te maken met verschillende zorgverleners in verschillende echelons. Zo kan iemand bijvoorbeeld zorg ontvangen van een specialist, huisarts, radiotherapeut, pastor, psycholoog en een wijkverpleegkundige. Al die zorgverleners zijn gespecialiseerd in een bepaald aspect van het ziekte- en zorgproces, waarbij het risico bestaat dat de zorg niet door én persoon gecoördineerd wordt en er onvoldoende sprake is van een duidelijke taakafbakening. Men spreekt ook wel van een gefragmenteerde, gespecialiseerde gezondheidszorg. In deze gefragmenteerde en gespecialiseerde gezondheidszorg is er meer ruimte en aandacht voor het medisch-technisch handelen dan voor de individuele ervaringen en beleving van de patiënt en zijn omgeving (Philipsen, 1988). Het zal daarom enige inspanning kosten om de zorg zodanig te organiseren dat er sprake is van afstemming tussen de verschillende zorgverleners rondom de patiënt en van afstemming van het zorgaanbod op de ervaren behoeften en de leefwereld van de patiënt. Voorwaarden voor afstemming, zoals een beperkt aantal zorgverleners, onderlinge contacten, samenwerking, het volgen van de patiënt in de tijd, taakafbakening en kennis en informatie over de leefwereld en behoeften van de patiënt, zijn immers niet altijd als vanzelfsprekend aanwezig.

Het probleem van de afstemming van de professionele zorgverlening vormt in ons onderzoek onderwerp van studie. We noemen de mate van afstemming in dit onderzoek continuïteit van de zorgverlening. Ons doel is een beschrijving te geven van de mate van continuïteit van de professionele zorgverlening bij mensen met kanker en daarnaast te onderzoeken in hoeverre de mate van continuïteit van de zorgverlening van invloed is op kwaliteit van leven en het beloop daarvan. Tot nu toe is er in onderzoek weinig aandacht geweest voor de relatie tussen continuiteit van de zorgverlening en kwaliteit van leven. Dit is verwonderlijk omdat het aannemelijk is dat een geringe mate van afstemming leidt tot hiaten in de zorg, met als gevolg negatieve invloeden op het welbevinden en functioneren van patiënten.

\subsubsection{Sociale steun}

Naast de professionele zorgverlening worden de sociale relaties van patiënten bestudeerd. Sociale steun en professionele zorgverlening kunnen inhoudelijk hetzelfde zijn, maar sociale steun is, in tegenstelling tot professionele zorgverlening, niet beroepsmatig en vloeit voort uit de relaties die mensen in een sociaal netwerk met elkaar onderhouden. Uit verschillende studies bij kankerpatiënten is gebleken dat 
sociale relaties in positieve zin van betekenis kunnen zijn voor de kwaliteit van leven (Wortman, 1984: Kutner, 1987; Northouse, 1988). Sociale steun vanuit een goed functionsrend netwerk kan een positieve invloed hebben op het welbevinden en de gezondheid. In dit onderzoek wordt nagaan in hoeverre structurele aspecten van het sociale netwerk (zoals grootte, samenstelling en dichtheid) en doelstellingsaspecten (zoals de hoeveelheid emotionele en praktische steun), van invloed zijn op de ervaren kwaliteit van het leven. Daarbij wordt verwacht dat er gedurende het ziekteproces veranderingen zullen optreden in de sociale relaties van patiënten. Er is nog betrekkelijk weinig onderzoek bekend dat zich richt op die veranderingen binnen het sociale netwerk en sociale steun gedurende de ziekteperiode (Ros, 1990). Dat is de reden waarom aspecten van sociale steun en veranderingen daarbinnen in het hier beschreven onderzoek longitudinaal worden bestudeerd.

\subsection{Persoonsgebonden kenmerken in dit onderzoek}

Een tweede groep van kenmerken waarvan de relatie met kwaliteit van leven onderzocht wordt betreft een aantal persoonsgebonden kenmerken. De mate waarin afhankelijkheid bestaat en de wijze waarop mensen reageren op de gebeurtenissen die hen overkomen worden, behalve door aan ziekte gerelateerde factoren, mede bepaald door iemands sociale positie; de plaats die iemand inneemt in de maatschappij. De sociale positie wordt onder meer bepaald door sekse, leeftijd, sociaaleconomische status en burgerlijke staat, kenmerken waarvan uit eerder onderzoek is gebleken dat ze van invloed zijn op de kwaliteit van het leven (o.a. Diener, 1984). Naast sociale positie is ook de waardenoriëntatie van belang. Het begrip waardenorientatie omvat een gegeneraliseerd en georganiseerd geheel van opvattingen, fundamentele inzichten, waarden en richtlijnen voor normen die het gedrag van mensen beïnvloeden. We beperken ons hier tot een aspect van de waardenoriëntatie waarvan herhaaldelijk is aangetoond dat dit van invloed is op gezondheidsgedrag en kwaliteit van leven: de beheersingsoriëntatie (Halfens, 1985; Philipsen, 1988; De Witte, 1991). Het gaat daarbij om de mate waarin men de opvatting heeft zelf invloed te kunnen uitoefenen op ziekte en gezondheid, of dat ziekte en gezondheid extern wordt bepaald, onder invloed van 'machtige' anderen (bijvoorbeeld artsen) of het toeval (bijvoorbeeld geluk of het lot).

\subsection{Een precisering van de probleemstelling}

De belangrijkste elementen van dit onderzoek werden in de voorafgaande paragrafen kort aangestipt. Nu wordt de probleemstelling nader gepreciseerd en worden de onderzochte concepten weergegeven in het onderzoeksmodel in figuur 1.1.

De probleemstelling in ons onderzoek betreft de vraag of er, behalve de invloed van ziekte en behandeling op kwaliteit van leven, ook sprake is van invloed van continuïteit van de professionele zorgverlening en sociale steun op (het beloop van) de kwaliteit van leven bij kankerpatiënten. We trachten de verschillen in kwaliteit van leven en veranderingen daarin te verklaren vanuit de volgende factoren: ziekte en behandeling, continuïteit van de professionele zorgverlening, sociale steun, sociale positie en beheersingsoriëntatie. 
De te onderzoeken relaties tussen deze factoren worden in het onderzoeksmodel in figuur 1.1 als pijlen weergegeven en worden hierna besproken.

Figuur 1.1 Het onderzoeksmodel

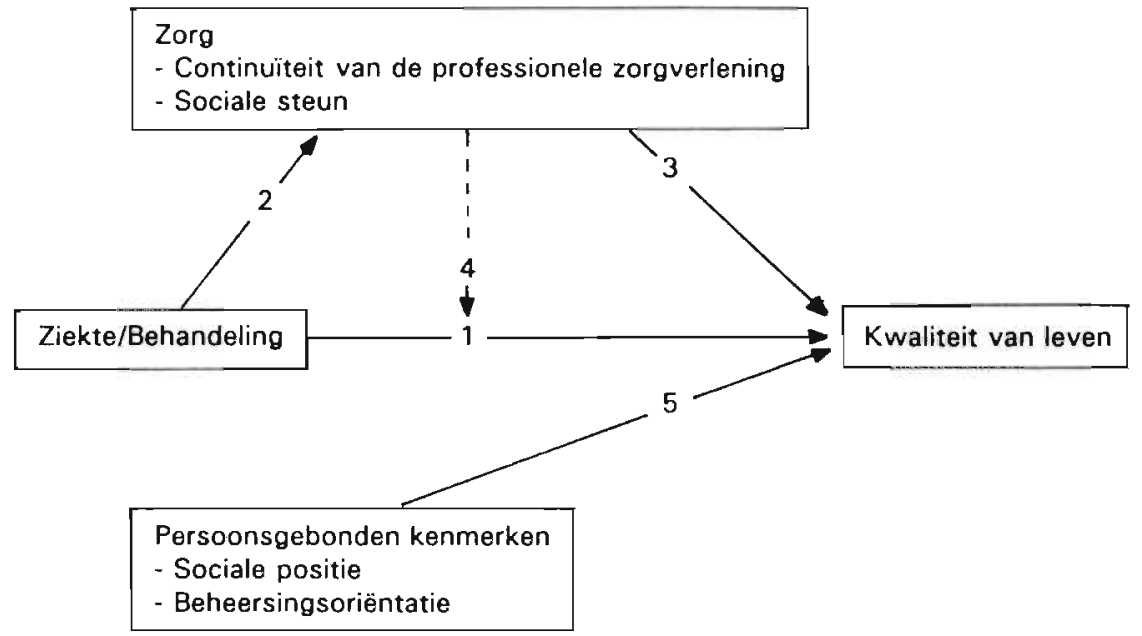

Pijl 1 Ziekte en behandeling in relatie tot kwaliteit van leven

De ervaren kwaliteit van leven en het beloop daarvan zal voor een deel beïnvloed worden door kenmerken van de ziekte en de behandeling die de patiënt heeft ondergaan. Het gaat om kenmerken als ziektestadium, ziekteduur, overlevingsprognose en de aard van de behandeling. In het algemeen verwachten we dat bij patiënten die ernstig ziek zijn, die een slechte overlevingsprognose hebben, en/of patiënten waarbij de ziekte zich in een gemetastaseerd stadium bevindt, de kwaliteit van het leven meer wordt aangetast dan bij patiënten waarbij dit niet het geval is. Ook de ziekteduur kan van invloed zijn. Naarmate het tijdsverloop na diagnose en behandeling langer is en de patiënt vrij van ziekte is, zal de kwaliteit van leven waarschijnlijk verbeteren. In dit onderzoek wordt nagegaan of en in welke mate kenmerken van de ziekte en de behandeling van invloed zijn op de kwaliteit van leven en het beloop daarvan.

\section{Pijl 2 Ziekte en behandeling in relatie tot professionele zorg en sociale steun}

Ziekte leidt tot bepaalde zorgbehoeften en dus, als de patiënt zelf niet aan die behoefte kan voldoen, tot zorgverlening en steun van anderen. Deze zorg zal in mindere of meerdere mate zijn gecoördineerd en afgestemd op de zorgbehoefte van de patiënt. Naarmate mensen ernstiger ziek zijn, zullen ze meer zorg en steun nodig hebben. Wanneer ze veel behandelingen moeten ondergaan, vaak in het ziekenhuis worden opgenomen en veel mensen bij het zorgproces betrokken zijn, kost het meer inspanning om de zorg te organiseren en zal meer sociale steun vanuit de omgeving gemobiliseerd moeten worden dan wanneer mensen minder ernstig ziek zijn. Het zal dan moeilijker zijn om afgestemde zorg te bereiken. 
Onderzocht zal worden welke relatie bestaat tussen ziekte en behandelingskenmerken enerzijds en de mate van continuïteit van de professionele zorgverlening en sociale steun anderzijds.

\section{Pijl 3 Kenmerken van de zorg in relatie tot kwaliteit van leven}

In dit onderzoek wordt een aantal kenmerken van professionele zorgverlening bestudeerd die voorwaarden vormen voor continuiteit in de zorgverlening: de afstemming van de zorg tussen zorgverleners onderling, ook wel coördinatie van zorg of organisatiegerichte afstemming genoemd, en de mate waarin er afstemming bestaat van het zorgaanbod op de leefwereld en behoeften van de patiënt, ook wel patiëntgerichte afstemming genoemd. Verwacht wordt dat bij een beter afgestemde zorg op organisatorisch en inhoudelijk gebied er minder doublures of tekorten in de zorg optreden en de kwaliteit van leven van de patiënt gunstig wordt beïnvloed.

Naast de kenmerken van professionele zorgverlening wordt ook sociale steun gerelateerd aan kwaliteit van leven. In dit onderzoek wordt nagegaan of functionele kenmerken van sociale steun en structurele kenmerken van het sociale netwerk van invloed zijn op de kwaliteit van het leven, waarbij wordt verwacht dat de ervaren sociale steun, vanuit een groot en open netwerk, een positieve uitwerking heeft op kwaliteit van leven.

\section{Pijl 4 Buffereffecten van zorg}

Steun en zorg kunnen wellicht een verzachtende invloed hebben op de negatieve gevolgen van stressoren, die in dit geval gevormd worden door de ziekte en de behandeling. Continuïteit van de professionele zorgverlening en sociale steun zouden de persion voor een deel kunnen beschermen tegen de negatieve gevolgen van de ziekte en behandeling. Men zou kunnen spreken van een buffereffect van de zorg. Naast het bestuderen van de directe samenhang tussen zorg en kwaliteit van leven wordt ook nagegaan of er eventueel sprake is van een buffereffect.

\section{Pijl 5 Persoonsgebonden kenmerken in relatie tot kwaliteit van leven}

Bij de persoonsgebonden kenmerken beperken we ons tot sociale positie en beheersingsoriëntatie. Verwacht wordt dat een aantal sociaal-demografische kenmerken, die iemands sociale positie bepalen en de beheersingsoriëntatie van invloed zijn op de mate van kwaliteit van leven.

Opgemerkt moet worden dat de aangegeven relaties niet volledig zijn. Ook andere relaties zijn mogelijk, bijvoorbeeld tussen sociale positie en continuïteit van zorg of tussen ziekte en sociale positie. We beperken ons in dit onderzoek echter tot de relaties die in het onderstaande model zijn weergegeven omdat we met name geïnteresseerd zijn in de factoren die kwaliteit van leven beïnvloeden. 


\section{Probleemstelling en literatuurstudie}

In dit hoofdstuk worden de concepten uit het onderzoeksmodel nader gedefinieerd en wordt een overzicht gegeven van de literatuur. Ten eerste zal worden ingegaan op het begrip kwaliteit van leven en de invloed van kanker op kwaliteit van leven. Daarna worden ziekte- en behandelingskenmerken en hun relatie tot de kwaliteit van leven beschreven. Vervolgens komen de begrippen continuïteit van de professionele zorgverlening en sociale steun aan de orde. Tenslotte worden enkele persoonsgebonden kenmerken en hun relatie tot kwaliteit van leven behandeld. Bij de bespreking van de onderzoeksliteratuur wordt toegewerkt naar vraagstellingen en hypotheses, die in de laatste paragraaf worden beschreven.

\subsection{De betekenis van het begrip kwaliteit van leven}

De laatste jaren is er binnen de gezondheidszorg veel aandacht voor kwaliteit van leven, met name op het gebied van chronische ziekten. Deze aandacht is verklaarbaar vanuit een aantal ontwikkelingen binnen de gezondheidszorg (Levine, 1987; Diederiks, 1987):

- In de gezondheidszorg is door het toenemende aantal chronisch zieken meer nadruk komen te liggen op andere succescriteria voor interventies dan die gebruikelijk waren bij acute ziekte. Naast levensverwachting, morbiditeit en mortaliteit is er sprake van steeds meer aandacht voor het functioneren van patiënten in het dagelijks leven en het welbevinden.

- Het is, zeker bij chronische ziekten, vaak onduidelijk of medische interventies leiden tot substantiële verlenging en verbetering van het leven. Om nieuwe interventies te kunnen rechtvaardigen is men andere ('kwaliteit van leven-achtige') criteria gaan stellen.

- Uit oogpunt van kostenbeheersing van de gezondheidszorg is een rationele keuze tussen concurrerende interventie-strategieën gewenst. Kwaliteit van leven kan gebruikt worden als evaluatiecriterium voor die interventies.

- De opkomst van de holistische benadering in de gezondheidszorg waarbij de nadruk meer ligt op het algemeen functioneren en welbevinden dan op de levensverwachting. 
Vooral binnen de oncologie is de aandacht voor kwaliteit van leven groot, met name omdat de ziekte ingrijpend is en van de vaak belastende behandelingen soms nog onduidelijk is welke effecten ze hebben op genezing en verlenging van het leven (De Haes, 1988).

Bij 'kwaliteit van leven' doet zich het probleem voor dat het begrip divers gedefinieerd en geoperationaliseerd is (De Haes, 1988; Diederiks, 1987; Van Dam, 1983). Er kunnen in het algemeen tenminste twee ordeningsprincipes voor de verschillende benaderingen worden onderscheiden: een ordening naar objectieve dan wel subjectieve benaderingen en een ordening naar globale dan wel multidimensionele uitwerkingen van het begrip.

\subsection{1 \\ Een objectieve dan wel subjectieve benadering van 'kwaliteit van} leven'

Objectieve maten worden veelal gebruikt bij de beschrijving van aspecten van een samenleving en de ontwikkelingen daarbinnen. In de uitwerking van de objectieve benadering worden 'harde' kenmerken zoals het aantal psychiatrische opnamen, morbiditeit, opleidingsniveau, urbanisatiegraad, voedingstoestand e.d. gezien als indicatoren van kwaliteit van leven (De Haes, 1988; De Witte 1989). Daarnaast spreekt men van een objectieve benadering als er sprake is van de beoordeling van kwaliteit van leven door professionele zorgverleners, zoals bijvoorbeeld artsen of verpleegkundigen.

In de oncologie werd oorspronkelijk in klinisch onderzoek veel gebruik gemaakt van de zogenaamde 'Karnofsky index', een objectieve maat, waarbij de arts de mogelijkheid om normale activiteiten uit te kunnen voeren, de behoefte aan zorg van anderen en de afhankelijkheid van de medische zorg van de patiēnt beoordeelt (Clark e.a, 1986). Onderzoek van Slevin (1988) wijst echter uit dat de kwaliteit van leven door patiënten anders wordt beoordeeld dan door artsen. Nehemkis (1984) vergeleek de scores van kankerpatiënten op een schaal voor kwaliteit van leven met de scores van oncologen, verpleegkundigen en andere professionele zorgverleners. De zorgverleners onderschatten veelal het belang van veranderingen in het dagelijks leven van patiënten. Bovendien overschatten de artsen en in mindere mate de verpleegkundigen het belang van 'pijn' bij deze groep kankerpatiënten. Ook Presant (1984) concludeert dat artsen onvoldoende in staat zijn om de kwaliteit van het leven van patiënten te beoordelen; de correlaties tussen scores op de Karnofsky schaal ingevuld door patiënten en artsen zijn dan ook laag.

Najman en Levine (1981) concluderen uit hun onderzoek dat objectieve indicatoren allén onvoldoende inzichten geven in de beleving van patiënten; zij pleiten voor een subjectieve benadering van kwaliteit van leven. Het (ideologische) uitgangspunt dat aan de subjectieve benadering ten grondslag ligt is namelijk dat de enige die deskundig is inzake welzijnsvragen, de betrokken persoon zelf is (De Groot, 1978). De laatste jaren zijn instrumenten voor 'kwaliteit van leven' dan ook vooral ontworpen vanuit een subjectieve benadering. In ons onderzoek wordt aangesloten bij deze subjectieve benadering; het gaat on de gevolgen van de ziekte en aspecten van de organisatie van de zorg op de door de patiënt ervaren kwaliteit van leven. 
Dit betekent dat we bij de operationalisatie van kwaliteit van leven (zie hoofdstuk 3) gekozen hebben voor vragenlijsten die door de patiënten zelf te beantwoorden waren.

Een multidimensionele of globale benadering van het begrip kwaliteit van leven

In de multidimensionele uitwerking van kwaliteit van leven worden vaak verschillende aspecten en dimensies van de situatie naast elkaar gemeten. Men definieert componenten van het leven die belangrijk zijn voor de kwaliteit ervan, zoals klachten, gevoelens van welbevinden en verstoring van het lichaamsbeeld (Sprangers, 1990). Bij de globale benadering wordt kwaliteit van leven gezien als de mate van geluk of tevredenheid met het leven in het algemeen.

Het is steeds gebruikelijker geworden om kwaliteit van leven als een multidimensioneel begrip te beschouwen. Bij recent ontworpen instrumenten zijn meestal zowel vragen over een aantal dimensies, zoals lichamelijk functioneren en psychisch welbevinden, als vragen over de globale beoordeling van het leven opgenomen, waarbij het globale oordeel in het algemeen gehanteerd wordt als een dimensie die gelijkwaardig is aan de specifieke dimensies (De Haes, 1988). Het gebruik van een globale maat naast de specifieke dimensies heeft het voordeel dat men kan achterhalen hoe de beoordelingen van specifieke aspecten van het functioneren of welbevinden gerelateerd zijn aan een globaal oordeel over de kwaliteit van leven. In ons onderzoek is gekozen voor een combinatie van de multidimensionele en globale benadering van kwaliteit van leven waarbij de dimensies geordend worden naar een aantal betekenissen van het ziek-zijn.

Kwaliteit van leven kan bestudeerd worden door middel van het hanteren van een indeling van verschillende betekenissen van ziek-zijn.

Ziek-zijn heeft op de eerste plaats de betekenis van de aanwezigheid van een aandoening, ofwel een met diagnostische procedures objectief vast te stellen stoornis in de werking van een of meerdere organen. In het Engels wordt deze betekenis disease genoemd (Parsons, 1951; Philipsen, 1969). Veelal gaat het bij onderzoek naar kwaliteit van leven om de invloed die de objectief waarneembare aandoening, de 'disease', heeft op het welbevinden en het functioneren in het dagelijks leven van de patiënt. In ons onderzoek vormt de diagnose kanker het disease-aspect dat gerelateerd wordt aan kwaliteit van leven. Voor het bestuderen van het begrip kwaliteit van leven zijn, gezien de subjectieve benadering die we gekozen hebben, de twee volgende betekenissen van ziekte van belang.

Ziek-zijn heeft een tweede betekenis, namelijk die van het subjectieve onwelbevinden, dat gerelateerd wordt aan de veronderstelde aandoening. In het Engels wordt dit illness genoemd. We denken hierbij aan de aan- of afwezigheid van door de patiënt ervaren klachten zoals pijn, angst, moeheid, en globale tevredenheid met het leven. Het gaat bij illness dus vooral om de belevingsaspecten van het ziek-zijn. Het is een subjectief begrip, dat ook op een subjectieve wijze gemeten wordt. 
Tenslotte is er een derde betekenis van ziek-zijn. Dit betreft de invloed op het dagelijks functioneren van mensen. Het gaat hier om het beroep dat de zieke doet op de samenleving, om 'tijdelijk' ontheven te worden van zijn maatschappelijke verplichtingen en functies. Door de ziekte is het mogelijk dat men niet meer aan die verplichtingen kan voldoen (Parsons, 1951; Philipsen, 1969). In het Engels wordt hiervoor de term sickness gebruikt. Het betreft de invloed van het ziek-zijn op het functioneren in lichamelijke, psychische en sociale aspecten, zoals bijvoorbeeld werk, huishouden, vrije tijd, lichaamsverzorging en mobiliteit. Het gaat bij sickness meer om de gedragsmatige aspecten van kwaliteit van leven. Het disfunctioneren ten gevolge van het ziek-zijn kan door de patiënt zelf op een bepaalde manier ervaren worden, maar kan ook door anderen objectief beoordeeld worden. Een ander kan bijvoorbeeld zien of de patient in staat is om bijvoorbeeld boodschappen te doen. Sickness wordt daarom een intersubjectief begrip genoemd. In ons onderzoek wordt het begrip op subjectieve wijze gemeten door aan de patiënt zelf vragen te stellen over zijn/haar gedrag.

Het gaat bij de beoordeling van de kwaliteit van leven om de mate waarin er een discrepantie bestaat tussen de gewenste of verwachte leefsituatie en de werkelijke situatie. In ons onderzoek hanteren we kwaliteit van leven vanuit een multidimensionele benadering, waarbij moet worden opgemerkt dat een globaal oordeel over het leven deel uit maakt van de verschillende dimensies. De te onderscheiden dimensies zijn:

- de mate waarin er volgens de patiënt sprake is van disfunctioneren (sickness) en - het globale onwelbevinden en klachten (illness).

De verschillende dimensies worden op een subjectieve manier gemeten, dat wil zeggen dat er wordt uitgegaan van de ervaring of het oordeel van de patiënt zelf.

\subsubsection{Onderzoek naar kwaliteit van leven bij kankerpatiënten}

In het algemeen verwacht men bij kankerpatiënten een verslechterde kwaliteit van leven op grond van de ernst van de ziekte en de vaak belastende behandelingen. Toch geven onderzoeken op dit terrein geen eenduidig beeld. Uit literatuuronderzoek van De Haes en Knippenberg (1985) blijkt dat kwaliteit van leven van kankerpatiënten in negatieve zin, maar soms ook in positieve zin verschilt van die van 'gezonden'. Als belangrijke algemene lichamelijke effecten worden verlies aan eetlust, vermagering, moeheid en slecht functioneren van verschillende organen, zoals lever, darmen, nieren, hart en longen, verstoringen van de hormoonhuishouding, afweer en neurologische afwijkingen beschreven (Holland en Frei, 1982). Pijn kan ook in belangrijke mate aanwezig zijn, met name in een latere fase van het ziekteproces (Dorrepaal, 1989).

Naast deze lichamelijke reacties kan kanker ook nogal wat psychische gevolgen hebben. In veel onderzoeken naar het psychisch functioneren van kankerpatiënten worden angst en depressiviteit als de meest voorkomende reacties beschreven (Van den Borne en Pruyn, 1985). Andere emotionele reacties die vaak blijken voor te komen zijn gevoelens van nutteloosheid, schaamte, prikkelbaarheid, slapeloosheid en schuldgevoelens. Daarnaast worden ook positieve gevolgen genoemd; patiënten zouden na confrontatie met de ziekte een positievere kijk op hun leven hebben, zich 
richten op prettige dingen en die meer waarderen dan voor de ziekte (Mack, 1984; Van Doorn \& Zeldenrust, 1983).

Kanker heeft ook op sociaal gebied consequenties. Vaak heeft de ziekte een negatieve weerslag op relaties met partners, gezinsleden, vrienden en kennissen. Ook blijkt de ziekte te kunnen leiden tot vermindering van sociale activiteiten en/of verlies van werk (Maguire, 1978; Van den Borne en Pruyn, 1985). Wortman (1984) beschrijft negatieve gevolgen als stigmatisering, verlies van sociale relaties, overbezorgdheid, overdreven aandacht, afhankelijk maken en infantiliseren. Als gevolg van het ziek-zijn blijken 'externe' contacten vaak te verschuiven naar contacten met gezin en vrienden (Magis \& Mendelsohn, 1979; Van den Borne \& Pruyn, 1985). Het gezinsleven kan negatief worden beïnvloed, iets dat volgens sommigen vooral tussen de derde en zesde maand na diagnose en behandeling manifest wordt (Gordon e.a., 1980). Daarnaast worden als gevolg van de ziekte en behandeling problemen in seksuele relaties beschreven. Maguire (1978) rapporteert dat $40 \%$ van de door hem onderzochte borstkankerpatiënten seksuele problemen heeft na borstamputatie. Uit een onderzoek bij 36 patiënten met verschillende vormen van kanker, die chemotherapie kregen, bleek dat bij 14 van de patiënten de behoefte aan seksueel contact afnam, terwijl bij 18 patiënten de behoefte aan nietseksueel lichamelijk contact toenam (Leiber, 1976).

Kankerpatiënten kunnen ook geconfronteerd worden met problemen in de werksfeer. $\mathrm{Ze}$ kunnen werkloos of afgekeurd worden of genoodzaakt zijn om minder te gaan werken of om ander werk te zoeken, met alle financiële consequenties van dien (De Haes, 1988; Greenwald e.a., 1989). Toch worden ook positieve veranderingen op sociaal gebied beschreven zoals het verbeteren van contacten met familie en vrienden en het meer waarderen van sociale contacten (Taylor, 1983; Van Doorn \& Zeldenrust, 1983). Er wordt tevens een toename en verandering van vrije tijdsbesteding gerapporteerd; men gaat meer op vakantie, men onderneemt meer creatieve activiteiten, maar men gaat minder uit en doet minder aan sport dan voor de ziekte (Sie, 1980 in De Haes, 1988).

Uit de literatuur wordt duidelijk dat het functioneren en welbevinden van patiënten, veelal in negatieve zin, maar soms ook in positieve zin verandert door het ziek-zijn. Verwacht wordt derhalve dat de kwaliteit van leven door de ziekte en de behandeling verminderd zal zijn en dat er soms ook verbeteringen in bepaalde dimensies van kwaliteit van leven zullen optreden.

\subsection{Kenmerken van ziekte c.q. behandeling en kwaliteit van leven}

De problemen die zich voordoen in het functioneren en welbevinden van patiënten, zijn voor een deel afhankelijk van ziektekenmerken zoals de diagnose, het stadium waarin de ziekte zich bevindt, de ziekteduur, de overlevingsprognose en de behandeling die de patiënt heeft ondergaan. In het algemeen kan men verwachten dat naarmate een patiënt ernstiger ziek is, de kwaliteit van het leven meer wordt aangetast.

Nadat bij patiënten de diagnose kanker is vastgesteld, komen de behandelingsmogelijkheden aan de orde. De keuze van de behandeling wordt met name bepaald door 
de maligniteit, de conditie van de patiënt en de locatie en uitbreiding van de tumor. De uitbreiding van het tumorproces wordt vastgesteld met het zogenaamde TNM classificatiesysteem, aan de hand waarvan een keuze gemaakt kan worden tussen locale behandeling (chirurgie en/of radiotherapie) en/of een systeembehandeling met behulp van chemotherapie. Deze behandelingsmethoden kunnen gericht zijn op curatie, dat wil zeggen volledige genezing, of ze kunnen palliatief van aard zijn. Dat betekent dat de behandeling is gericht op het behoud van functioneren en welbevinden en het voorkomen van verslechtering. Hieronder wordt ingegaan op de relatie tussen de genoemde kenmerken van ziekte en behandeling en kwaliteit van leven.

\subsubsection{Diagnose}

In veel onderzoeken worden verschillen in functioneren en welbevinden in relatie tot de diagnose niet duidelijk; er blijken weinig specifieke verschillen te zijn tussen diagnosegroepen (Cookfair, 1983; Knippenberg, 1983; Silberfarb e.a., 1980; De Haes, 1988). Soms worden wel verschillen aangetoond. Oleske (1990) concludeert uit onderzoek naar gezondheidsproblemen bij patiënten met borst-, colon- en longkanker dat de patiënten met longkanker de meeste klachten hebben. De Haes vindt (1988) enkele kleine verschillen tussen diagnosegroepen: patiënten met een rectumcarcinoom hebben een slechter lichaamsbeeld dan patiënten met een mammacarcinoom, ovariumcarcinoom of Hodgkin c.q. Non-Hodgkin lymphomen. Ze rapporteren bovendien meer positieve sociale ervaringen, maar kunnen minder rollen uitoefenen dan andere groepen, zoals rollen met betrekking tot werk, huishouden, en vrije tijd.

De verwachting voor ons onderzoek is dat tussen diagnosegroepen weinig specifieke verschillen gevonden zullen worden in kwaliteit van leven.

\subsubsection{Stadium, ziekteduur en overlevingsprognose}

Uit verschillende onderzoeken zijn er aanwijzingen dat de ziekteduur, het stadium van de ziekte en de overlevingsprognose van invloed zijn op kwaliteit van leven. De Haes (1988) vergeleek de kwaliteit van leven van drie groepen kankerpatiënten met een steekproef uit de 'normale' bevolking. Kwaliteit van leven wordt door De Haes als een globale maat gedefinieerd. Twee van de drie groepen patiënten bevinden zich in een zogenaamde crisissituatie: patiënten die recent zijn geopereerd en patiënten die een chemotherapie-behandeling hebben ondergaan. Een derde groep is drie jaar of langer vrij van ziektesymptomen. Bij patiënten in crisis is de kwaliteit van leven slechter dan die van de controlegroep, de 'normale' populatie. Bij de ziektevrije patiënten is de kwaliteit van leven niet aangetast. Bovendien is een toename gevonden van het activiteitenniveau van patiënten naarmate opname in het ziekenhuis langer geleden is. Uit eerder onderzoek van De Haes (1986) bij patiënten met borstkanker in een vroeg stadium blijkt de kwaliteit van leven toe te nemen tussen 11 en 18 maanden na borstamputatie. Deze resultaten bevestigen wat Van den Borne en Pruyn (1985) schrijven met betrekking tot de factoren die het duidelijkst gerelateerd lijken te zijn aan het niveau van psychische problemen. De eerste fase van het ziek-zijn (waarin de diagnose wordt gesteld en de behandeling plaatsvindt) 
en de eerste drie maanden daarna blijken vaak samen te gaan met emotionele problemen. Na ongeveer een jaar lijken de problemen minder groot (Maguire e.a., 1978). Samengevat lijkt het erop dat in de fase van diagnostiek en behandeling, kwaliteit van leven wordt aangetast. De problemen lijken minder groot te worden naarmate het tijdsverloop na die fase langer is en de patiënt ziektevrij is.

Anders wordt het als er sprake is van metastasering, een slechte prognose en/of terugkeer van de ziekte. Onderzoek wijst uit dat mensen met een slechtere prognose een slechter lichaamsbeeld hebben, minder rolactiviteiten kunnen uitoefenen en minder mobiel zijn dan mensen met een goede prognose (De Haes, 1988). Volgens Linssen (1979) en Priestman e.a. (1981) is bij een slechte prognose en na metastasering het lichamelijk functioneren van patiënten slechter dan bij patiënten waarbij deze kenmerken niet van toepassing zijn.

Als de ziekte terugkomt dan blijken mensen vaak meer emotionele problemen te hebben dan bij de eerste keer (Van den Borne en Pruyn, 1985; Silberfarb, 1980).

Bij patiënten die uiteindelijk in een terminale fase van de ziekte verkeren, zal de kwaliteit van leven waarschijnlijk het sterkst zijn aangetast. Morris (1987) onderzocht kwaliteit van leven in verschillende stadia van het ziekteproces, bij terminale patiënten in een verpleeghuis en bij een groep kankerpatiënten die thuis verbleven. Er blijkt pas ongeveer vier weken voor het overlijden een sterke vermindering van kwaliteit van leven op te treden. Mor (1987) vergeleek drie groepen patiënten: nieuwe patiënten, patiënten onder actieve behandeling en terminale patiënten. Op een 'kwaliteit van leven' index scoorden nieuwe patiënten het hoogst, gevolgd door patiënten onder behandeling. De terminale patiënten scoorden aanmerkelijk lager, dat wil zeggen dat ze een slechtere kwaliteit van leven rapporteerden. Patiënten die in een vergevorderd stadium van de ziekte verkeren en een slechte prognose hebben zullen waarschijnlijk op alle aspecten slechter functioneren en dus minder sociale activiteiten kunnen ondernemen. Uit onderzoek van Morris e.a. (1987) blijkt dat patiënten in de laatste twee maanden van hun leven vaak niet meer in staat zijn om voor zichzelf te zorgen en meestal ook niet meer aan activiteiten buitenshuis kunnen deelnemen. Passieve tijdsbesteding kan soms nog wel worden voortgezet.

Het lijkt erop dat de overlevingsprognose, het stadium waarin de ziekte zich bevindt en het tijdsverloop sinds diagnose en behandeling voorspellende factoren zijn voor kwaliteit van leven. Verwacht wordt dat in de eerste fase van het ziek-zijn (de fase van diagnostiek en behandeling), bij een slechte prognose, bij metastasering en bij de terminale fase kwaliteit van leven sterker wordt aangetast dan bij een guede prognose en afwezigheid van metastasen. Bovendien wordt verwacht dat naarmate het tijdsverloop na diagnose en behandeling langer is en de patiënt 'ziektevrij' is, de kwaliteit van leven zal toenemen; waarschijnlijk omdat de invloed van de confrontatie met de diagnose en de invloed van de behandeling is afgenomen en patiënten zich in zekere zin aan de situatie hebben aangepast. 
De chirurgische behandeling is de oudste behandelingsmethode van kanker. Daarnaast worden radiotherapie en chemotherapie, al dan niet in combinatie met andere methoden, toegepast.

Verschillende vormen van chirurgie kunnen ten gunste of juist ten nadele van specifieke functies werken. Chirurgie kan ingrijpende gevolgen hebben, zeker als het gaat om sterk mutilerende operaties zoals borstamputatie, stoma of laryngectomie. Mogelijke gevolgen zijn: perioperatieve sterfte, hartfunctiestoornissen, (long)oedeem, verminderd seksueel functioneren, verminderde spraak- en slikfunctie (Kazem, 1983; De Haes, 1988). Op het psychische vlak zou vooral het lichaamsbeeld van patiënten aangetast zijn (De Haes 1986). Naarmate operaties radicaler zijn zouden ze meer negatieve effecten hebben op het psychisch welbevinden en functioneren (Taylor, 1985). Verschillende behandelingsvormen kunnen de sociale activiteiten van patiënten zowel positief als negatief beïnvloeden. Uit onderzoek naar de invloed van kringspiersparende chirurgie bij rectumkanker blijkt bijvoorbeeld dat patiënten hun werk beter konden blijven doen dan patiënten waarbij de kringspier niet gespaard was (Williams en Johnston, 1983). Bij vrouwen bij wie een gynaecologische tumor geconstateerd is, blijkt dat $84 \%$ van de vrouwen na een uitgebreide operatie in het kleine bekken hun normale activiteiten kunnen hervatten, terwijl $46 \%$ van de vrouwen die een dergelijke operatie niet hebben ondergaan hun normale rolactiviteiten kunnen uitvoeren (Blythe en Wahl, 1981).

Chemotherapie wordt vaak gezien als de meest ingrijpende behandeling. Ze heeft verschillende effecten op lichamelijk functioneren zoals: haaruitval, moeheid, misselijkheid, braken, mond en slikklachten, veranderingen in huid, nagels, smaak en reuk, myocardopathie, neuropathie, decompensatio cordis, longfibrose, aantasting van lever, nieren, urinewegen, beenmerg en voortplantingsorganen en leukemie (Goodman, 1989; De Haes, 1988; Kazem, 1983). De mate waarin deze klachten voorkomen is afhankelijk van de dosering en het moment waarop de kuren plaatsvinden. Chemotherapie kan voor het begin van de kuur angst en erna depressies oproepen (Hughes, 1982). Ook worden invloeden op het cognitief functioneren, nervositeit, prikkelbaarheid, slaapproblemen en angst gerapporteerd (Goodman, 1989; Silberfarb e.a, 1980; Meyerowitz e.a., 1979). Bij palliatieve behandeling is de aantasting van het psychisch welbevinden sterker dan bij curatieve behandelingen. Uit het onderzoek van De Haes (1988) blijkt dat mensen die chemotherapie hebben ondergaan meer lichamelijke en psychische klachten hebben en minder betrokken zijn bij maatschappelijke en politieke activiteiten of problemen dan de patiënten die pas geopereerd zijn. Sugarbaker (1982) onderzocht patiënten met sarcomen van de 'weke delen' van extremiteiten, die behandeld zijn door middel van amputatie in combinatie met chemotherapie of door middel van een combinatie van radiotherapie en chemotherapie. De patiënten waarbij een amputatie heeft plaatsgevonden rapporteren op een aantal aspecten een hogere kwaliteit van leven dan de andere groep patiënten. Op sociaal gebied kan de behandeling met chemotherapie ook consequenties hebben. Meyerowitz (1983) constateert dat $75 \%$ van de borstkankerpatiënten die adjuvante chemotherapie hebben ondergaan minder actief in hun 
werk zijn dan voorheen. Velen kunnen het huishouden niet meer doen of het huis niet meer verlaten. Ten aanzien van de gevolgen van de behandeling op het onderhouden van sociale relaties zijn wat de behandelmethoden betreft weinig verschillen gevonden. De Haes (1988) rapporteert dat chemotherapie-patiënten minder positieve sociale ervaringen hebben dan patiënten die net geopereerd zijn. Uit onderzoek van Linssen (1982) blijkt dat patiënten die enige tijd geleden chemotherapie hebben ondergaan meer tevreden zijn over de zorg van hun partner dan mensen uit een 'gezonde' populatie.

Radiotherapie kan een aantal klachten met zich mee brengen, maar kan ook leiden tot behoud van het lichamelijk functioneren. Gevolgen die genoemd worden zijn: moeheid, verminderde eetlust, misselijkheid en braken, nieuwe tumoren, aantasting van het immuunsysteem, erytheem, bindweefselvorming, kortademigheid, diarree en slikklachten (Kazem, 1983; De Haes, 1988). Zowel vlak voor als na de behandeling blijken veel patiënten zich onzeker te voelen. Ze gaan piekeren, worden zenuwachtig en gespannen, krijgen angstgevoelens en klagen over slapeloosheid (Nocross Weintraub, 1990, Van Knippenberg, 1983; Wortman en Dunkel-Schetter, 1979; Van den Borne en Pruyn, 1985). Uit onderzoek van Harwood e.a (1983) blijkt dat mensen die in een vroeg stadium van de ziekte verkeren na bestraling beter kunnen blijven werken dan mensen die geopereerd zijn.

Omdat chemotherapie vaak als de meest ingrijpende vorm van behandeling wordt beschreven en veel lichamelijke, psychische en sociale consequenties heeft, wordt verwacht dat de kwaliteit van leven, bij mensen die behandeld werden door middel van chemotherapie, slechter is dan bij patiënten die andere behandelmethoden hebben ondergaan.

Samenvattend kan worden gesteld dat de specifieke vorm van kanker of de diagnose niet het belangrijkste ziektekenmerk is dat de kwaliteit van leven van mensen met kanker beïnvloedt. Ziekteduur, behandeling, het stadium waarin de ziekte zich bevindt en de overlevingsprognose zijn factoren die belangrijker lijken te zijn.

\subsection{Professionele zorgverlening en sociale steun}

Kanker kan leiden tot disfunctioneren, tot onwelbevinden en tot toenemende afhankelijkheid. Het individu heeft tijdens de verschillende fasen van het ziekteproces bepaalde zorgbehoften waarin hij afhankelijk wordt van anderen. Om aan de verschillende zorgbehoeften te kunnen voldoen kan men in het algemeen uit vier 'zorgbronnen' putten: zelfzorgvermogen, professionele zorgverlening, sociale steun en lotgenotencontacten. In dit onderzoek beperken we ons tot enkele aspecten van professionele zorgverlening en sociale steun.

Professionele zorgverlening wordt gedefinieerd als het geheel van intentioneel weloverwogen en beroepsmatig handelen dat zich richt op het oplossen van gezondheidsproblemen van mensen. Het vereist zowel arbeidsdeling, kennis en verworven vaardigheden, als informatie over de toestand waarin iemand zich bevindt, inclusief de opvattingen, belangen en bezorgdheden van de zorgontvanger 
(Orem, 1985; Philipsen, 1988). Onder professionele zorgverleners verstaan we onder andere artsen, verpleegkundigen, fysiotherapeuten en psychologen.

Ruwweg zijn er vier doeleinden die in de professionele zorgverlening worden nagestreefd (Philipsen, 1988):

- Behandeling en genezing: activiteiten die gericht zijn op geheel of gedeeltelijk herstel van gezondheid, op voorkoming van gezondheidsproblemen of op verergering daarvan.

- Verpleging en verzorging: activiteiten die gericht zijn op aanvulling, herstel of overname van de zelfzorg op momenten dat de patiënt niet in staat is om voor zich zelf te zorgen.

- Ondersteuning en begeleiding: activiteiten als advisering en voorlichting waardoor mensen beter met hun gezondheidsproblemen of tekorten in hun zelfzorg kunnen omgaan.

- Er bij zijn als iemand lijdt: het tonen van solidariteit en toewijding aan de patiënt bij ziekte en gebrek.

Voor een goed begrip van de zorgverlening is het van belang een onderscheid te maken tussen het netwerk en de organisatie waarbinnen de zorg wordt gegeven (structurele kenmerken) enerzijds en de inhoud van de zorg en de betekenis van de zorg voor de patiënt anderzijds (doelstellingskenmerken).

De tweede zorgbron, die in dit proefschrift behandeld wordt, wordt gevormd door de sociale relaties van het individu. De zorg die door de mensen uit het sociale netwerk gegeven wordt noemen we sociale steun.

Een gangbare definitie van dit begrip is:

de mate waarin de sociale behoeften van een individu worden bevredigd door interactie met anderen (Thoits, 1982).

Als belangrijkste elementen van sociale steun onderscheidt men doorgaans (Cobb, 1976; House, 1981; Vliert en de Boer, 1984; Ormel, 1984; Tempelaar, 1987) :

- emotionele steun (vriendschap, begrip, vertrouwen)

- waarderingssteun (respect, bewondering, waardering)

- aanwezigheidssteun (deel uit maken van een netwerk, aanwezigheid van anderen)

- instrumentele steun (financiële hulp, praktische hulp, adviseren).

Professionele zorg en sociale steun vullen elkaar aan. Daar waar het gaat om zeer specifieke zorgbehoeften, bijvoorbeeld een medische behandeling, is professionele zorgverlening doorgaans vanzelfsprekend. Bij andere aspecten van de zorgverlening, zoals verpleging en verzorging, begeleiding, het bij-iemand-zijn, speelt sociale steun een grote rol. Uit onderzoek van Van den Bos (1989) blijkt dat chronisch zieke mensen eerst proberen in hun eigen omgeving hulp te zoeken. Pas als de informele sector niet meer aan de zorgbehoefte kan voldoen, worden beroepskrachten ingeschakeld. Professionele zorg heeft als het ware een consoliderend effect op de steun uit het sociale netwerk.

De inhoud van de zorg kan voor professionele zorg en sociale steun hetzelfde zijn. Een belangrijk onderdeel van professionele zorgverlening wordt gevormd door het 
ondersteunen, het adviseren, het bij-iemand- zijn of praktische huip geven. Professionele zorgverlening vindt echter beroepsmatig en weloverwogen plaats, terwijl sociale steun voortvloeit uit of deel uitmaakt van de relaties die mensen uit een sociaal netwerk reeds voor de ziekte met elkaar onderhouden. Bij sociale steun zal ook vaker dan bij professionele zorgverlening sprake zijn van een zekere wederkerigheid van de zorg.

Ook bij sociale steun is het van belang een onderscheid te maken tussen de structurele kenmerken of wel het sociale netwerk waarbinnen steun wordt gegeven (alle potentiële steunverleners, relevante netwerkleden) en de inhoud en kwaliteit van de steun (doelstellingskenmerken).

Hoewel het mogelijk is dat professionele zorgverleners deel uit maken van het sociale netwerk van de patiënt, maken we in ons onderzoek een onderscheid tussen zorgverlening door beroepskrachten of professionele zorgverleners en sociale steun gegeven door mensen uit de directe omgeving van de patiënt. Uit onderzoek van Janssen (1992) blijkt overigens dat een gering aantal chronisch zieken professionals tot hun sociale netwerk rekenen.

In de volgende vier paragrafen wordt nader ingegaan op continuïteit van de professionele zorgverlening en op sociale steun. Er wordt uiteengezet wat onder de begrippen wordt verstaan. Voorts wordt de relatie tussen de kenmerken van zorg en kwaliteit van leven beschreven.

\subsubsection{Continuïteit van professionele zorgverlening}

De gezondheidszorg vormt een segment van de samenleving waarbinnen een zekere ontwikkeling naar modernisering geldt (Philipsen, 1988; Zijderveld, 1983). Dit betekent dat de gezondheidszorg wordt gekenmerkt door een hoge mate van functionele rationaliteit, gericht op doelverwezenlijking van medische behandelingen en een vergaande differentiatie en specialisatie naar functies, taken en voorzieningen. Deze ontwikkeling heeft een aantal (potentiële) problemen tot gevolg, waar vooral chronische patiënten mee geconfronteerd kunnen worden:

- Individuele patiënten hebben contact met tal van gespecialiseerde zorgverleners uit verschillende echelons, zoals de specialist, de huisarts, radiotherapeut, ziekenhuisverpleegkundigen, wijkverpleegkundigen en de gezinszorg. Elke zorgverlener of voorziening beoordeelt daarbij de eigen doelmatigheid en doeltreffendheid van de zorg, waarbij de kans bestaat dat hij of zij het zicht op de zorg als geheel verliest. Dit wordt ook wel fragmentatie van de zorg genoemd.

- Door de groeiende specialisatie spreken professionele zorgverleners elkaars taal niet meer, ze hebben hun eigen taakopvattingen, waarden en normen, waardoor communicatie bemoeilijkt wordt. Men spreekt van culturele discontinuïteit binnen de gezondheidszorg (Diederiks, 1987; Zijderveld, 1987).

- Patiënten worden gedurende langere tijd afhankelijk van de zorg van anderen. Kenmerkend voor de ziekte kanker is dat deze min of meer chronisch genoemd kan worden. De aandoening is geen incident maar vormt een geïntegreerd onderdeel van het dagelijks leven van de patiënt. Er vinden vaak wisselende ziekte- en zorgepisodes plaats tijdens de zogenaamde patiëntenloopbaan of 'trajectory' (Strauss, 1984). 
De zorgepisodes zouden samenhangend moeten zijn en aan elkaar gerelateerd. Voor zorgverleners is het vaak moeilijk om patiënten, die te maken hebben met verschillende zorgverleners en echelons, tijdens hun patiëntenloopbaan te blijven volgen.

- De behandeling van patiënten wordt gemakkelijk beschouwd als een project waaraan op doelrationele wijze 'gesleuteld' kan worden. De patiënt wordt daarbij vaak het object van een project. Zo'n project is bijvoorbeeld de genezing van een wond na een borstamputatie. De patiënte die net een amputatie heeft ondergaan, is echter vooral een subject. Zij zal immers haar ziek zijn, de amputatie op haar eigen manier beleven. Het ziek-zijn vormt een geïntegreerd en wezenlijk onderdeel van het leven van de patiënte en dat van haar naasten. Voor de mens als subject is er in veel projecten binnen de gezondheidszorg onvoldoende aandacht. Door deze toenemende projectmatigheid in de gezondheidszorg is het mogelijk dat de ziekte, in strikt medische zin, meer centraal staat dan de zieke.

Samengevat kunnen we stellen:

1. Gezien het grote aantal verschillende zorgverleners wordt de behoefte aan coördinatie steeds groter. Communicatieproblemen tussen zorgverleners bemoeilijken echter deze coördinatie.

2. Er bestaat een waardenconflict tussen de gezondheidszorg (als een instrumenteel systeem gericht op medisch technisch handelen) en de belevingswereld van patiënten.

Door bovenstaande kenmerken van de moderne gezondheidszorg kan men zich voorstellen dat er problemen in de afstemming of continuïteit van de zorgverlening ontstaan. Het is niet eenvoudig de zorgverlening zo te organiseren dat er sprake is van een geheel van ononderbroken zorgactiviteiten die gericht zijn op de behoeften van de patiënt. Met andere woorden, problemen in de continuïteit van de zorgverlening kan men beschouwen als gevolgen van bovengenoemde spanningsvelden in de gezondheidszorg.

In de verschillende velden van de gezondheidszorg vormt continuïteit van de professionele zorgverlening een actueel onderwerp. In rapporten en artikelen wordt regelmatig geschreven over nazorg, zorg-overdracht, 24- uurszorg en casemanagement. Zowel beroepsorganisaties van huisartsen als van wijkverpleegkundigen beschouwen coördinatie van zorg als een belangrijke taak van de huisarts respectievelijk de wijkverpleegkundige.

Een probleem is dat het begrip 'continuïteit van zorg' vaak verschillend wordt gedefinieerd. Sommige auteurs benadrukken de afstemming van zorgactiviteiten tussen zorgverleners, instituties en voorzieningen (Nationale Kruisvereniging, 1985; Jansen, 1985; Bachrach, 1981; Hansen, 1975). Anderen nemen de (veranderlijke) zorgbehoeften van de individuele patiënt als uitgangspunt (Grol, 1987; Noordhoek, 1986; Shortell, 1976). Weer anderen zien continuïteit van zorg als de relatie van de individuele patiënt met steeds dezelfde arts (Magill, 1987; Becker, 1974; Curtis, 1979; Grol, 1987).

In onze studie richten we ons zowel op de afstemming van de zorg van zorgverleners onderling, (ook wel organisatiegerichte afstemming of coördinatie van zorg genoemd), als op de afstemming van de zorg op de behoeften en ervaringen van 
patiënten, (ook wel patiëntgerichte afstemming genoemd). Daarbij moet worden opgemerkt dat organisatiegerichte afstemming geen doel op zich is maar een voorwaarde vormt om patiëntgerichte zorg te kunnen verlenen.

Continuïteit van de professionele zorgverlening wordt in ons onderzoek gedefinieerd als de mate waarin de zorg bestaat uit een gecoördineerd en geïntegreerd geheel van activiteiten dat gericht is op de leefwereld en de behoeften van de patiënt gedurende de hele periode van het ziek-zijn. Het gaat daarbij niet om de doelmatigheid, de financiering of de organisatie van voorzieningen. Deze laten we buiten beschouwing. Het is ook niet de bedoeling om normatieve uitspraken te doen over de kwaliteit van de zorg.

Min of meer analoog aan de vier genoemde probleerngebieden (fragmentatie, culturele discontinuïteit, projectmatigheid en wisselende ziekteperiodes) in de professionele zorgverlening kunnen vier aspecten van continuïteit van de professionele zorgverlening worden benoemd. Deze aspecten vormen een indirecte manier om de mate van coördinatie van zorg en patiëntgerichte afstemming te bepalen. De daadwerkelijke inhoud van de zorg blijft buiten beschouwing.

\subsubsection{1}

\section{Structurele aspecten}

Om inzicht te verwerven in de mate waarin er sprake is van coördinatie van de zorg is het noodzakelijk te weten welke zorgverleners bij de zorg voor een patiënt betrokken zijn en in welke mate er contacten bestaan tussen deze verschillende zorgverleners. Deze contacten moeten leiden tot informatieuitwisseling zodat de verschillende zorgactiviteiten zodanig op elkaar kunnen worden afgestemd dat ze complementair zijn, elkaar versterken en niet met elkaar in tegenspraak zijn (Jansen e.a, 1985; Bachrach, 1981; De Witte, 1991). Verwacht wordt dat bij patiënten die zeer frequent en met zeer veel verschillende professionele hulpverleners contacten onderhouden, de zorg moeilijker te organiseren is. Als er bij het zorgproces van een patiënt een beperkt aantal zorgverleners betrokken is (die allen het deel van het zorgproces op zich nemen dat tot hun takenpakket behoort) zullen er waarschijnlijk minder problemen ontstaan dan wanneer er veel zorgverleners betrokken zijn bij de zorg. In dat laatste geval zal de zorg moeilijker te organiseren zijn en bestaat het gevaar dat er hiaten of doublures in de zorg ontstaan. Om inzicht te krijgen in de omvang van de professionele zorgverlening is in ons onderzoek het aantal betrokken zorgverleners ofwel de grootte van het professionele netwerk onderzocht. Daarnaast is nagegaan in hoeverre deze zorgverleners onderlinge contacten onderhouden. Deze twee maten vormen indicatoren voor de continuïteit van de zorgverlening. De operationalisatie hiervan wordt in hoofdstuk drie beschreven.

\subsubsection{2}

\section{Culturele aspect}

Een tweede voorwaarde voor coördinatie van de zorg (die nauw samenhangt met de mate waarin er sprake is van onderling contact en informatieuitwisseling), is de overeenstemming over de takkopvattingen van de verschillende zorgverleners (Van der Wouden, 1986; Van Beek, 1984; Cuisinier, 1984; Engelsman, 1988; De Witte, 
1991). Dit aspect wordt 'cultureel' genoemd omdat de taakopvattingen van een zorgverlener mede bepaald worden door de waarden, normen en cultuur die in een bepaalde beroepsgroep of discipline heerst. Een onduidelijke taakafbakening kan leiden tot onduidelijkheden over de te verlenen zorg, tot frictie tussen zorgverleners en tot tegenstrijdigheden of hiaten in de zorg (Engelsman, 1988). De afstemming van taken vormt in ons onderzoek de derde indicator voor de mate van continuïteit van de professionele zorgverlening.

\subsubsection{3}

Tijdsaspect

Continuïteit van de zorgverlening kan men vanuit een tijdsperspectief beschouwen, waarbij er aandacht aanwezig is voor ontwikkelingen die de patiënt doormaakt. Veel auteurs noemen dan ook de longitudinale zorg van steeds dezelfde zorgverlener als voorwaarde voor continuïteit van zorg (Grol, 1987; Magill, 1987; Becker, 1974). $\mathrm{Zij}$ gaan er vanuit dat er tussen patiënt en zorgverlener een vertrouwensrelatie ontstaat waarin de zorgverlener de patiënt en zijn leefwereld c.q. behoeften kent en rekening houdt met de voorgeschiedenis en het ziektebeloop (Grol, 1987). Het tijdsaspect hangt in feite nauw samen met het structurele aspect; het aantal verschillende zorgverleners waar men mee te maken heeft in een bepaalde ziekteepisode, bepaalt mede de grootte van het professionele netwerk. Bovendien zal als men met meer zorgverleners contacten onderhoudt, de noodzaak voor onderlinge contacten ook groter zijn. Het gaat bij dit aspect echter vooral om de ononderbroken zorg, waarbij de gehele ziekteperiode van de patiënt in beschouwing wordt genomen. De geboden zorg zou moeten samenhangen met de episodes in de ziekte en de 'loopbaan' van de patiënt. Hierbij hoort volgens enkele auteurs ook de ononderbroken voortgang van de zorgverlening binnen en tussen instellingen, van ziekenhuis naar de thuissituatie en omgekeerd (Grijpdonck, 1989; Shortell, 1976; Bachrach, 1981).

Ook in ons onderzoek worden de zorgverlening door steeds dezelfde zorgverleners en de zorg voor patiënten vóór en na opname in het ziekenhuis als belangrijke indicatoren voor continuiteit van zorgverlening beschouwd.

\subsubsection{4}

Doelstellingsaspect

Als vierde aspect kan de mate waarin de doelstellingen van de zorgverlening aansluiten op de leefwereld en de behoeften van de patiënt, worden genoemd (Bachrach, 1981; Grol, 1987; de Witte, 1991). Er zijn twee indicatoren te noemen voor de mate waarin de zorg aansluit op de behoeften en beleving van de patiënt: tevredenheid over de zorg en overeenstemming over zorgbehoeften. Het eerste punt betreft de tevredenheid van de patiënt en de mensen in zijn omgeving over de ontvangen zorg. Door een inventarisatie te maken van de door patiënten ervaren knelpunten kan inzicht verkregen worden in de mate van afstemming van de zorg op de zorgbehoeften. Een voorwaarde voor deze afstemming is de mate waarin bij de zorgverleners kennis bestaat over de zorgbehoeften van de patiënt. De mate van overeenstemming met betrekking tot zorgbehoeften tussen patiënten en zorgverleners wordt als tweede indicator voor het doelstellingsaspect gebruikt. 
Alhoewel er in het algemeen een redelijke mate van consensus lijkt te zijn over het feit dat er in de gezondheidszorg een probleem van continuîteit van zorg bestaat, is er weinig empirisch onderzoek verricht naar de relatie tussen continuïteit van zorg en kwaliteit van leven. Onderzoek naar continuïteit van zorg betreft veelal de organisatie van voorzieningen. In onderzoek worden culturele verschillen tussen beroepsgroepen, de gebrekkige consultatie, contacten en informatiestromen en onvoldoende samenwerking tussen professionele hulpverleners benadrukt (Van der Wouden, 1986; Visser e.a, 1987; De Witte, 1986, 1991; Engelsman e.a., 1989). Verschillende auteurs beschrijven bijvoorbeeld het gebrek aan taakafbakening tussen de specialist en de huisarts. Dit gebrek aan consensus betreft vooral de rol van de huisarts bij de ziekenhuisopname van de patiënt, bij aspecten van diagnostiek en bij het afbakenen van verantwoordelijkheden (Van Beek, 1984; Cuisinier, 1984; Van der Wouden, 1986; De Melker, 1973). Uit onderzoek van Engelsman e.a. (1988) blijkt dat bij kankerpatiënten zowel huisartsen, specialisten als wijk- en ziekenhuisverpleegkundigen zich richten op medische aspecten van de zorg, op informatieverstrekking en op psychosociale problematiek. Het ontstaan van doublures en tegenstrijdigheden in de zorg is hierdoor niet ondenkbaar.

Er zijn in de literatuur enkele aanwijzingen gevonden voor een samenhang tussen continuïteit van de professionele zorgverlening en kwaliteit van leven. Onderzoeken naar longitudinale zorg door één, en dezelfde hulpverlener geven aan dat deze zorg de tevredenheid, het welbevinden en de compliance van patiënten vergroot (Grol, 1987; Starfield, 1976; Becker, 1974; Wills, 1978).

Wat de afstemming van het zorgaanbod op de zorgbehoeften van kankerpatiënten (patiëntgerichte afstemming) betreft, wordt in beschrijvende onderzoeken, ondanks de overheersende tevredenheid van patiënten, vooral gewezen op knelpunten in de psychosociale ondersteuning van patiënten en familieleden en in de voorlichting (Cuisinier, 1984; Engelsman e.a, 1989; Ten Kate e.a, 1988).

Volgens verschillende onderzoekers komt het regelmatig voor dat zorgverleners een andere inschatting maken van de zorgbehoeften dan de patiënten zelf. Discrepanties tussen de perceptie van zorgverleners en patiënten wat welbevinden, functioneren en zorgbehoefte betreft kunnen leiden tot een gebrekkige communicatie, inadequate zorgverlening en een slechte compliance (Mohlzahn, 1989). Holmes' (1989) studie bij 53 kankerpatiënten laat significante verschillen zien tussen verpleegkundigen en patiënten met betrekking tot perceptie van klachten zoals misselijkheid, slaap, concentratie en stemming. Verpleegkundigen beoordelen al deze aspecten ernstiger dan de patiënten zelf. Uit een onderzoek van Gerber (1980) blijkt dat verpleegkundigen het belang van veranderingen in sociale relaties en seksueel functioneren van patiënten overschatten, terwijl ze problemen met betrekking tot dieet, reizen en huishoudelijke activiteiten onderschatten. Het inschatten van huishoudelijke problemen lijkt ook voor huisartsen een probleem. Uit een onderzoek van Patrick e.a. (1982) kan worden geconcludeerd dat de helft van de huisartsen op de hoogte is van problemen met activiteiten van het dagelijks leven, slechts $30 \%$ van de 
huisartsen op de hoogte is van problemen die patiënten rapporteren met betrekking tot het huishouden, en een nog kleiner percentage op de hoogte is van mobiliteitsproblemen en het gebruik van hulpmiddelen door hun patiënten. Ook bij psychische problemen worden verschillen gevonden. Zo laten Jennings e.a (1981) zien dat professionele zorgverleners meer 'angst' en 'depressie' bij patiënten rapporteren dan patiënten zelf. Uit een onderzoek naar continuïteit van zorg bij revalidatiepatiënten (De Witte e.a, 1985) blijkt dat huisartsen en wijkverpleegkundigen de ernst van de aandoening en de mate van hinder gemiddeld negatiever inschatten dan de patiënt, terwijl zij de gezondheid en het lichamelijk functioneren positiever beoordelen dan de patiënt.

Enkele onderzoeken wijzen op een positief verband tussen patiëntgerichte afstemming en kwaliteit van leven. Uit onderzoeken van Ben-Sira $(1982,1986)$ blijkt dat affeclief gedrag van professionele zorgverleners en afstemming van doelen een positieve relatie hebben tot succes bij revalidatie. Dit ligt in de lijn van onderzoek van Bard e.a.(1977) waaruit naar voren komt dat patiënten die veel steun ontvangen van professionals zich beter aanpassen aan complicaties na een borstamputatie. Onderzoek van Funch e.a. (1982) bij kankerpatiënten wijst uit dat naarmate de communicatie tussen patiënt en professionele zorgverlener adequater verloopt, de patiënt zich in psychisch opzicht beter aanpast aan de ziekte. Ook Ros (1990) concludeert uit zijn onderzoek naar steun in relatie tot kwaliteit van leven dat informatieve steun van professionele hulpverleners samenhangt met een hogere kwaliteit van leven en minder depressiviteit.

In het onderzoek van de Witte (1991) naar continuïteit van de zorgverlening bij revalidatiepatiënten is geen relatie gevonden tussen de mate van continuïteit van zorgverlening en het functioneren. De verklaring die de onderzoeker hier zelf voor heeft is dat bij geen van de onderzochte patiënten sprake is van continuïteit van zorg; de gebruikte variabelen differentiëren niet voldoende om de relatie tussen continuïteit van zorg en kwaliteit van leven te onderzoeken.

Verwacht wordt dat naarmate de zorg beter gecoördineerd is, (als patiënten niet te veel verschillende zorgverleners hebben, er sprake is van onderlinge contacten tussen zorgverleners, een duidelijke taakafbakening en samenhang van de zorg in de tijd) er minder doublures of tekorten in de zorg zullen optreden. Deze coördinatie heeft waarschijnlijk positieve effecten op de aansluiting van het zorgaanbod op de zorgbehoeften van de patiënt en daardoor op de kwaliteit van het leven. Bovendien wordt verwacht dat de beschreven indicatoren van de patiëntgerichte afstemming, tevredenheid van de patiënt met de zorg en de mate waarin de perceptie van de zorgverleners en de patiënt ten aanzien van de zorgbehoeften congruent is, samengaan met een betere kwaliteit van leven.

\subsubsection{Sociale steun}

Socialc steun kan niet helemaal los worden gezien van continuïteit van de professionele zorgverlening. De zorgbehoefte houdt immers niet op als patiënten ontslagen worden uit het ziekenhuis; thuis in hun eigen directe omgeving blijft een zekere zorgbehoefte bestaan en komt een deel van de zorg neer op het sociale 
netwerk. Sociale steun vormt als het ware een voorwaarde voor continuïteit van de zorgverlening.

Door velen wordt aangenomen dat adequate sociale steun positieve effecten heeft op welbevinden, gezondheid en functioneren van individuen (Wortman, 1984; OrthGomer, 1987; Kutner, 1987; Northouse, 1988). Volgens welk mechanisme dit effect tot stand komt is nog steeds onderwerp van studie. Verondersteld wordt dat in stressvolle situaties of bij psychosociale moeilijkheden, sociale steun adaptatieprocessen kan bevorderen en de invloed van deze stressvolle situaties op de gezondheid kan verzachten. Sociale steun heeft dan een buffereffect (Lin, 1985). Door enkele onderzoekers wordt een direct effect van sociale steun op de gezondheid gerapporteerd. De afwezigheid van sociale steun zal leiden tot psychisch en somatisch onwelbevinden (De Jong-Gierveld en Van Tilburg, 1986). Daarnaast speelt sociale steun een rol bij de bevordering van gezond gedrag en het verkrijgen van informatie (Mootz, 1981; Tempelaar, 1989).

Bij kankerpatiënten kunnen moeilijkheden ontstaan binnen de sociale relaties (Wortman \& Dunkel-Schetter, 1979; Glaser \& Strauss, 1973; De Swaan, 1982). In onderzoek naar problemen van mensen met borst- en longkanker en sarcomen constateren Gordon e.a (1980) dat de meerderheid van de patiënten gebrek aan open communicatie met vrienden en familie als probleem aangeeft. In de reacties van anderen op kankerpatiënten zit vaak een zekere angst; mensen zijn bang voor de ziekte en de confrontatie met de zieke en ze vertonen vermijdingsgedrag (Wortman en Dunkel-Schetter, 1979, Wortman, 1984). Mensen voelen zich soms niet op hun gemak als ze met de patiënt omgaan. De ziekte en daarmee de zieke vervult hen met angst, aversie en afschuw. Shumaker and Brownell (1984) merken op dat de wederkerigheid van sociale steun een probleem vormt bij kankerpatiënten. De ziekte plaatst de zieke in een situatie die wordt gekenmerkt door inadequate wederkerigheid of toenemende afhankelijkheid. Deze verschillen in kracht en positie tussen de patiënt en zijn netwerkleden kunnen een belangrijke verandering vormen in de sociale relaties van kankerpatiënten. Veranderingen in het sociale netwerk van de patiënt kunnen onder andere verklaard worden vanuit de 'ruiltheorie' (Ormel, 1989). Hierbij wordt er vanuit gegaan dat zich herhalende (ruil)interacties de basis vormen voor de instandhouding van het sociale netwerk. De in het verleden gedane investeringen in de sociale relatie, alsmede het ingeschatte toekomstige nut van de sociale relatie zouden de keuze voor het aanhouden of afbreken van een contact kunnen verklaren (Flap, 1987). Als de patiënt zelf minder terug kan doen omdat hij ziek is, kan het aanhouden van de relatie voor de ander, maar ook voor de patiënt minder aantrekkelijk zijn. Verwacht wordt dat als gevolg van veranderingen in de gezondheidstoestand en veranderingen in de afhankelijkheidsbalans sociale relaties zullen wegvallen.

Bij het bestuderen van sociale steun worden veelal twee componenten onderscheiden: structurele en doelstellingsaspecten.

In de literatuur zijn aanwijzingen gevonden dat de structurele aspecten van het netwerk, die kunnen worden gezien als indicatoren voor sociale integratie, een direct effect hebben op welbevinden (o.a. Cohen en Wills, 1985). Dit wordt toegeschreven aan de effecten die sociale netwerken hebben op gevoelens van stabiliteit en 
zelfwaardering. De structurele kenmerken zijn echter vooral van belang omdat ze de basis vormen voor de hoeveelheid steun die potentieel ontvangen kan worden.

In dit onderzoek beperken we ons tot de volgende structurele aspecten: de grootte, de dichtheid en de samenstelling van het sociale netwerk.

- De grootte of de omvang van het netwerk is het antal mensen dat direct contact heeft met de centrale persoon, in dit geval de kankerpatiënt. Enkele onderzoekers ondersteunen de stelling dat een groot sociaal netwerk meer sociale steun biedt dan een klein netwerk (Hall en Wellman, 1985; Ormel, 1989).

- De dichtheid van het netwerk is de mate waarin leden van het netwerk contact met elkaar onderhouden. De relatie tussen de dichtheid van het netwerk en de hoeveelheid sociale steun is niet altijd duidelijk. Sommige auteurs beweren dat een dicht netwerk leidt tot meer ervaren steun (Wellman, 1979; Caplan, 1974). Anderen concluderen dat dichte netwerken juist leiden tot minder adequate steun (o.a. Granovetter, 1973). In een meer open netwerk zouden veranderingen opgevangen kunnen worden door nieuwe contacten, hetgeen de aanpassing aan die verandering zou kunnen bespoedigen.

- De samenstelling van het netwerk wordt in ons onderzoek gedefinieerd als de verhouding tussen het aantal familieleden en niet-familieleden. Verondersteld wordt dat als er meer verscheidenheid van relaties binnen een netwerk bestaat (bijvoorbeeld familie, vrienden, buren en collega's) de hoeveelheid steun groter is (Ormel, 1989; Knipscheer, 1980).

De doelstellingsaspecten bepalen vooral de kwaliteit van de sociale relaties en worden veelal belangrijker geacht dan de structurele kenmerken, als het gaat om effecten op welbevinden (De Jong-Gierveld, 1986; Wortman, 1984). De structurele en doelstellingsaspecten kunnen echter niet los van elkaar worden gezien. Ze zijn aan elkaar gerelateerd. Tot de doelstellingskenmerken behoren onder andere de hoeveelheid ervaren emotionele c.q. praktische steun alsmede de wederkerigheid van de steun.

De emotionele steun kan worden gedefinieerd als gedrag dat begrip, vertrouwen en liefde overbrengt. Praktische steun betreft meer tastbare, feitelijke hulp. Beide vormen van steun blijken in de verschillende fasen van het ziek-zijn van belang te zijn (Winnubst, 1989; Dunkel-Schetter, 1984).

De wederkerigheid van de steun is de mate waarin de centrale figuur zorg verleent aan de leden van het netwerk in relatie tot de ontvangen steun. Gezien de verwachte verschuivingen in de afhankelijkheidsbalans van patiënten is het belang van deze variabele evident.

\subsubsection{Onderzoek naar sociale steun in relatie tot kwaliteit van leven}

In tegenstelling tot het geringe aantal onderzoeken naar de relatie tussen continuïteit van professionele zorg en kwaliteit van leven is er veel onderzoek gedaan naar de effecten van sociale steun. In dit overzicht beperken we ons tot onderzoeken bij kankerpatiënten. In verschillende onderzoeken wordt een positieve relatie gevonden tussen sociale steun en kwaliteit van leven (Dunkel-Schetter, 1984; Funch e.a., 1982; Weisman, 1975). Volgens Meyerowitz (1980) hangen kenmerken van de 
sociale omgeving samen met ervaren ongemak en verstoring. In families waarin men zich kan uiten komen minder negatieve stemmingen voor dan in families waarin men dat niet kan. Een steunende familie kan tevens bijdragen aan een positievere kijk op het leven en hoop (Spiegel, 1984). Uit onderzoek van Bloom (1982) blijkt dat bij borstkankerpatiënten een grotere betrokkenheid van gezinsleden samenhangt met een betere aanpassing aan de ziekte. Bij patiënten met een slechte prognose blijkt er een positieve relatie te zijn tussen het hebben van een steunende omgeving en de fysieke conditie (Dunkel-Schetter, 1984).

De gevonden positieve correlaties tussen sociale steun en kwaliteit van leven worden vaak geïnterpreteerd als causale relaties waarbij sociale steun een goed functioneren en welbevinden veroorzaakt. Een alternatieve verklaring voor deze positieve correlatie is dat de gezondheidstoestand de hoeveelheid steun beïnvloedt: ernstig ziek-zijn leidt tot minder steun. Omgaan met mensen die ernstig ziek-zijn kan leiden tot gevoelens van onmacht, onbehagen en verminderde interesse (Ros, 1990; DunkelSchetter en Wortman, 1982). Het is anderzijds ook mogelijk dat ernstig zieke patiënten zelf hun interesse in anderen verliezen (Ros, 1990).

Er worden ook negatieve correlaties gevonden tussen sociale steun en kwaliteit van leven. Deze negatieve correlaties zouden kunnen wijzen op het min of meer logische idee dat ernstig zieke patiënten meer zorg en steun nodig hebben en die ook krijgen. Zo concludeert Tempelaar (1989) uit een onderzoek naar positieve en negatieve sociale ervaringen dat kankerpatiënten meer positieve en minder negatieve ervaringen met sociale steun hebben dan 'gezonde mensen'. Hoe slechter het gaat met kankerpatiënten, hoe meer steun ze ervaren. Dit is dus in strijd met wat onder andere Ros en Wortman beweren.

In literatuur overheerst het positieve effect van sociale steun. In ons onderzock verwachten we een positief verband tussen steun en kwaliteit van leven en een positieve samenhang tussen de mate van wederkerigheid en kwaliteit van leven.

Wat duidelijk wordt na bestudering van de literatuur is dat de ernst van de ziekte van invloed kan zijn op de hoeveelheid ervaren steun. In het onderzoek van Ros (1990) is het aantal significante verbanden tussen sociale steun en welbevinden groter bij patiënten met weinig gezondheidsklachten dan bij patiënten met veel gezondheidsklachten. Bij de eerste categorie patiënten leidt informatieve steun van familieleden en anderen, in de periode van diagnose en behandeling, tot een beter welbevinden. Bij patiënten met veel gezondheidsklachten is dat verband niet gevonden. Emotionele steun daarentegen blijkt geen oorzaak maar eerder een gevolg van een beter welbevinden. Tevens concludeert Ros dat patiënten in het begin van hun ziekteproces meer sociale steun ervaren dan later in het ziekteproces, als de situatie van de patiënten gemiddeld genomen is verslechterd. Dit geldt in het bijzonder voor de hoeveelheid emotionele steun van en de hoeveelheid contacten met zowel familie, partner en vrienden als artsen en andere professionele zorgverleners. Bij patiënten die na verloop van tijd in een ziektevrije periode komen, is te verwachten dat de hoeveelheid steun afneemt, omdat dan ook minder steun nodig is. De grootte van het sociale netwerk hoeft bij mensen die ziektevrij zijn, niet kleiner te worden. Wel is het waarschijnlijk dat het professionele netwerk kleiner wordt, omdat dan minder medische zorg nodig is. 
Bij mensen waarbij de situatie wel verslechtert verwachten we een afname van de steun en een verkleining van het netwerk. Verwacht wordt verder dat grote sociale netwerken die relatief 'open' zijn en divers van samenstelling een directe dan wel een indirecte positieve invloed hebben op kwaliteit van leven.

De verhouding tussen continuïteit van de professionele zorgverlening en sociale steun

De verhouding tussen continuïteit van de professionele zorgverlening en sociale steun kan in termen van complementariteit worden opgevat.

Wanneer een adequaat steunverlenend informeel netwerk aanwezig is, is de rol van professionals kleiner (Kemper, 1988). In sommige gevallen is een centrale verzorger uit het sociale netwerk zelfs in staat om de coördinatie van de zorg op zich te nemen (Van Achterberg e.a., 1992). Indien de informele sector echter niet meer aan de toenemende zorgbehoefte kan voldoen wordt de druk op de professionele zorg groter (Van den Bos, 1989). De noodzaak tot professionele zorg en het afstemmen van die professionele zorg is groter in situaties waarin de informele zorg niet aanwezig is of niet adequaat genoeg is. Zo blijkt bijvoorbeeld uit onderzoek van Frederiks (1985) dat een objectief identieke probleemsituatie bij alleenwonende ouderen eerder in een vraag om professionele hulp resulteert dan bij ouderen die samenwonen met anderen.

Daarnaast is er professionele zorg nodig in situaties waarin er zorgbehoeften bestaan die vragen om complexe en specifieke zorgactiviteiten die het zelfzorgvermogen en het vermogen van sociale netwerkleden te boven gaan. Het gaat dan bijvoorbeeld om medisch- of verpleegtechnische handelen, bijvoorbeeld het toedienen van chemotherapie per infuus.

\section{$2.4 \quad$ Persoonsgebonden kenmerken}

In deze paragraaf worden sociale positie en beheersingsoriëntatie in relatie tot kwaliteit van leven behandeld.

\subsubsection{Sociale positie}

$\mathrm{Bij}$ sociale positie gaat het om de plaats die iemand in de maatschappij inneemt, het netwerk van maatschappelijke relaties. Dit wordt voor een belangrijk deel gevormd door sociale rollen. Iemands sociale positie kan worden beschreven aan de hand van onder andere leeftijd, geslacht, sociale klasse, opleiding en burgerlijke staat. De sociale positie van iemand kan functioneren vergemakkelijken of bemoeilijken en het welbevinden beïnvloeden. Een relatief sterke positie (bijvoorbeeld man, jong, gehuwd, hoge sociaal-economische status) in de maatschappij kan een direct positief effect hebben op kwaliteit van leven. Mensen met een hogere status leven vaak in een gezondere omgeving, hebben een betere huisvesting, werken in een gezonder arbeidsmilieu en beschikken over meer financiële middelen. De sociale positie kan ook een indirect effect hebben en de invloed van ziekte en behandeling verzachten. 
Zo kan de sociale positie van invloed zijn op het gebruik van voorzieningen en op sociale steun.

Uit onderzoek is gebleken dat mensen uit hogere sociaal-economische lagen meer adequaat gebruik maken van de diensten en goederen in de gezondheidszorg (Deleeck, 1988). Ook uit onderzoek van Van den Bos (1989) blijkt dat oudere chronisch zieken uit hogere sociaal-economische groepen in vergelijking met ouderen in lagere groepen, (in overeenkomstige gezondheidstoestand) meer contact hebben met de specialist. Dit kan verklaard worden vanuit het feit dat hogere sociale categorieën in het algemeen meer belang hechten aan gezondheid, gezondere levenswijzen hebben, meer kennis hebben over gezondheid en de gezondheidszorg, meer toegang hebben tot informatiebronnen en meer vaardigheden hebben om met werkers in de gezondheidszorg om te gaan. Ook de verzekeringsvorm speelt daarbij een rol. Particulier verzekerden raadplegen een specialist vaker zonder eerst een huisarts te consulteren.

Alleenwonenden zullen relatief vaker aangewezen zijn op professionele zorg, met name in de sfeer van verpleging en verzorging (Van den Bos, 1989). Partners kunnen immers een belangrijke bron van steun zijn. Ook tussen leeftijd en het gebruik van professionele zorg wordt in het algemeen een positief verband gevonden.

De sociale positie kan ook van invloed zijn op sociale steun. Zo wijst onderzoek van van Eyk (1980) uit dat bij gezonde personen met een hoge status meer intensieve contacten bestaan met familie en vrienden, dan bij mensen met een lagere status. Uit onderzoek van Oakley en Rajan (1991) kan geconcludeerd worden dat vrouwen uit de middenklassen minder geïsoleerd leven en intensievere contacten onderhouden met hun familie, dan vrouwen uit lagere klassen. Leeftijd zou ook van invloed zijn op de hoeveelheid ervaren steun. Bij ouderen neemt de omvang van de netwerken door overlijden van netwerkleden en pensionering af (Knipscheer, 1980). Uit onderzoek van Janssen (1992) blijkt dat ouderen meer emotionele steun krijgen van familie en zelf minder praktische steun geven aan niet-familieleden, dan jongeren.

\subsubsection{Onderzoek naar sociale positie en kwaliteit van leven}

Uit veel onderzoeken blijkt dat sociaal-demografische variabelen samenhangen met kwaliteit van leven (Diener, 1984; De Haes, 1988). Uit onderzoeken in de 'normale' bevolking komt naar voren dat in het algemeen vrouwen, alleenstaanden en mensen uit de lagere sociaal-economische klassen een lagere kwaliteit van leven hebben dan mannen, gehuwden en mensen uit de hogere sociaal-economische klassen (De Haes, 1988; C.B.S., 1981; Veenhoven, 1984).

Uit onderzoek van De Witte (1989) naar kwaliteit van leven bij reumapatiënten blijkt dat alleenstaanden en mensen met een laag netto gezinsinkomen de kwaliteit van hun leven significant lager beoordelen dan mensen die met anderen samenwonen en meer inkomen hebben. Onderzoek naar het functioneren van revalidatiepatiënten laat eveneens zien dat patiënten met een lage sociaal-economische status, (die nauw gerelateerd is aan hoge leeftijd) een grotere kans hebben op een negatief beloop van het functioneren (De Witte, 1991). 
Onderzoek bij chronisch zieken wijst dus uit dat er verbanden zijn tussen leeftijd, geslacht en sociaal-economische status enerzijds en lichamelijke beperkingen, de ervaren gezondheid en psychisch functioneren anderzijds (Van den Bos, 1989).

De omvang van de lichamelijke beperkingen stijgt met de leeftijd. Depressieve klachten daarentegen worden in jongere leeftijdsgroepen meer gerapporteerd.

Vrouwen rapporteren in elke leeftijdsgroep meer lichamelijke beperkingen en meer psychische klachten dan mannen. Zij zijn vaker afhankelijk van hulp bij ADL en uiten ook meer depressieve gevoelens.

In de lagere sociaal-economische groepen worden meer lichamelijke beperkingen en meer depressieve klachten gerapporteerd in vergelijking met hogere sociaaleconomische groepen. Ook de ervaren gezondheid is in de lagere sociaal-economische groepen minder gunstig.

De relatie tussen sociaal-demografische variabelen en de kwaliteit van leven van kankerpatiënten is onduidelijk. In sommige onderzoeken blijken alleenstaanden een laag psychisch welbevinden te hebben (Schmale, 1983; Waltz, 1986). In het onderzoek van de Haes (1988) zijn gescheiden mensen minder tevreden over hun leven dan andere groepen. Daarentegen is er ook onderzoek waarin er geen verbanden worden gevonden tussen burgerlijke staat en welbevinden (Meyerowitz, 1979). Hetzelfde geldt voor geslacht, leeftijd en sociaal-economische status; er is geen duidelijke richting aan te geven. Tussen de sekse van de patiënt en kwaliteit van leven is geen duidelijk verband gevonden (De Haes, 1988; Cookfair, 1983 ; Schmale, 1983).

Een hoge leeftijd kan negatief samenhangen met het kunnen uitoefenen van gebruikelijke activiteiten en positief met zorgbehoeften, lichamelijke klachten en depressies (Geelen, 1984; Dobkin e.a, 1985; Cookfair, 1983). Daarentegen zouden jongeren zich onzekerder voelen en meer angst hebben dan ouderen (Geelen, 1984). Naar effecten van sociaal-economische status bij kankerpatiënten is nog weinig onderzoek gedaan. Weisman (1986) vindt in een onderzoek bij borstkankerpatiënten dat vrouwen met een hoge sociaal-economische status minder last hebben van bijkomende problemen na een amputatie dan vrouwen uit de lagere sociaaleconomische klassen. Meyerowitz e.a (1979), Cassileth e.a (1984) en de Haes (1988) vonden echter geen samenhang tussen het hebben van een baan, de gevolgde opleiding en welbevinden.

Dat de relatie tussen de sociaal-demografische kenmerken en kwaliteit van leven bij kankerpatiënten minder sterk is dan bij de normale bevolking heeft wellicht te maken met het feit dat ziekte en behandeling in de beleving van deze patiënten centraal staat. Daarom moet worden nagegaan of sociale positie wel een buffer kan vormen die de effecten van die ziekte en behandeling versterkt dan wel verzwakt. Bij het formuleren van de verwachtingen met betrekking tot sociale positie en kwaliteit van leven zijn we uitgaan van verbanden die in de 'normale' bevolking gevonden zijn. We verwachten een positief verband tussen het (gehuwd) samenwonen met een partner en kwaliteit van leven en een positief verband tussen sociaal-economische status en kwaliteit van leven. 


\subsubsection{De beheersingsoriëntatie}

De beheersingsoriëntatie kan van invloed zijn op gezondheidsgedrag en kwaliteit van leven (Diener, 1984; Halfens, 1985; Philipsen, 1988). Deze sociaal-cultureel bepaalde persoonlijkheidseigenschap, zou min of meer aangeleerd zijn in een later stadium van het leven en meer onderhevig zijn aan veranderingen dan de zogenaamde klassieke persoonlijkheidseigenschappen zoals zelfvertrouwen en neurotisisme (Diener, 1984; De Witte, 1991). Onder beheersingsoriëntatie of 'locus of control' wordt verstaan: de mate waarin een persoon gebeurtenissen in zijn omgeving ziet als iets dat onder zijn eigen controle staat of als iets dat buiten zijn controle ligt (Pruyn e.a., 1988). In empirisch onderzoek wordt beheersingsoriëntatie vaak gebruikt om gedrag met betrekking tot gezondheid te verklaren (Halfens, 1985). Daarbij worden gewoonlijk oriëntaties onderscheiden:

- Interne oriëntatie; de mens ziet zich zelf als belangrijkste bron van invloed,

- Externe oriëntatie: machtige anderen (bijvoorbeeld artsen) beïnvloeden het ziek worden en het verloop van de ziekte

- Kans- of toevaloriëntatie; men schrijft het ontstaan en verloop van ziekte aan toeval of geluk toe.

\subsubsection{Onderzoek naar beheersingsoriëntatie en kwaliteit van leven}

Uit onderzoek bij een steekproef uit de Nederlands bevolking blijkt dat mensen die een slechtere gezondheid bezitten, meer dan hun gezonde landgenoten menen dat hun gezondheid afhankelijk is van anderen; zij zijn meer extern georiënteerd (Halfens, 1985; Philipsen, 1988). De Witte (1991) vindt in zijn onderzoek naar het beloop van het functioneren van revalidatiepatiënten een verband tussen een sterke artsoriëntatie c.q. een lage interne oriëntatie enerzijds en een negatief beloop van kwaliteit van leven anderzijds.

Onder kankerpatiënten is nog betrekkelijk weinig onderzoek verricht naar de gevolgen van interne controle. Taylor (1983) suggereert dat naarmate mensen meer het idee hebben dat ze zelf invloed kunnen hebben op de ziekte zich makkelijker herstellen na een crisis. Ruf-Dirksen (1990) daarentegen vindt geen verband tussen een interne oriëntatie en welbevinden. Taylor, Lichtman en Wood (1984) vinden bij onderzoek onder kankerpatiënten een positief verband tussen het geloof dat machtige anderen (bijvoorbeeld de artsen) de kanker onder controle houden en het welbevinden. Pruyn e.a. (1988) concluderen uit hun onderzoek bij kankerpatiënten dat mensen met een hoge interne controle ten aanzien van het verloop van de ziekte verschillen van mensen met een lage interne controle. De intern georiëntecrden hebben minder controleverlies, zijn meer geneigd tot gezondheidsgerelateerd gedrag en zij zoeken en ontvangen meer sociale steun. Bovendien hebben zij minder last van angst en negatieve gevoelens, meer zelfwaardering en een positiever lichaamsbeeld dan mensen met een andere oriëntatie.

Verwacht wordt dat ook in ons onderzoek een positieve relatie bestaat tussen de mate waarin er sprake is van een interne beheersingsoriëntatie en kwaliteit van het leven. 


\subsection{Vraagstellingen en verwachtingen}

In deze paragraaf wordt de probleemstelling gespecificeerd naar vraagstellingen en verwachtingen.

Om een antwoord te kunnen geven op de probleemstelling is het noodzakelijk om eerst een beschrijving te geven van kwaliteit van leven, continuiteit van de professionele zorgverlening en sociale steun. Dit levert de volgende twee vraagstellingen op:

1. Hoe beoordelen patiënten die (recent) geconfronteerd werden met de diagnose kanker de kwaliteit van hun leven en welke veranderingen treden hierin op gedurende een jaar?

Verwacht wordt dat in eerste instantie de kwaliteit van leven verminderd zal zijn en in de loop der tijd zal verbeteren.

2. In welke mate is er sprake van continulteit van professionele zorgverlening en sociale steun bij deze categorie patiënten en welke veranderingen vinden hierin plaats gedurende een jaar van het ziekteproces?

Verwacht wordt dat kankerpatiënten te maken krijgen met fragmentatie, culturele discontinuitteit en projectmatigheid van de zorg omdat zij gedurende langere tijd intensief worden geconfronteerd met de gezondheidszorg.

Ten aanzien van sociale steun kunnen de volgende verwachtingen geformuleerd worden: sociale netwerken worden gemiddeld kleiner na verloop van tijd en de hoeveelheid ervaren emotionele en praktische steun neemt gemiddeld af in de tijd. Verder wordt verwacht dat bij kankerpatiënten de wederkerigheid van steun wordt aangetast.

Vervolgens tracht ons onderzoek de variantie in kwaliteit van leven te verklaren vanuit een aantal onafhankelijke factoren. Daartoe zijn de volgende vraagstellingen geformuleerd:

3. In welke mate hangen ziekte-gerelateerde factoren, sociale positie en de beheersingsoriëntatie samen met kwaliteit van leven en het beloop daarvan bij mensen met kanker?

In het algemeen wordt verwacht dat naarmate de objectieve ernst van de ziekte groter is, de kwaliteit van leven slechter en het beloop negatiever is.

Verwacht wordt voorts dat er tussen de diagnosegroepen weinig verschillen zullen zijn wat kwaliteit van leven betreft en dat chemotherapie van alle behandelingsmethoden de meest negatieve invloed heeft op kwaliteit van leven.

Ten aanzien van sociaal-demografische variabelen en de beheersingsoriëntatie verwachten we dat de sekse en de leeftijd van de patiënt niet samenhangen met kwaliteit van leven en het beloop daarvan en dat een hogere sociaal-economische 
status, het samenwonen met een partner en een interne beheersingsoriëntatie een positieve invloed hebben op kwaliteit van leven en het beloop daarvan.

4. In welke mate is er sprake van een relatie tussen de mate van continulteit van professionele zorgverlening en (het beloop van) kwalit'it van leven bij kankerpatiënten?

We verwachten dat patiënten bij wie er sprake is van continuïteit van de zorgverlening een betere kwaliteit van leven en een positiever beloop rapporteren dan patiënten bij wie de zorg niet of minder continu verloopt.

5. In welke mate is er sprake van een relatie tussen sociale steun en het beloop van) kwaliteit van leven bij kankerpatiënten?

Verwacht wordt dat patiënten met een groot netwerk, patiënten met een dicht netwerk en patiënten met een divers samengesteld netwerk een betere kwaliteit van leven en een positiever beloop daarvan rapporteren dan patiënten met een klein, dicht of eenzijdig samengesteld netwerk. Voorts wordt verwacht dat de hoeveelheid ervaren steun en wederkerigheid in de steun een positieve invloed hebben op kwaliteit van leven en het beloop daarvan.

6. In welke mate is er sprake van een relatie tussen ziekte- en behandelingskenmerken enerzijds en continuiteit van de professionele zorgverlening en sociale steun anderzijds?

Omdat de richting van de samenhang tussen ziekte en sociale steun c.q. continuïteit van de professionele zorgverlening niet eenduidig is, worden geen verwachtingen geformuleerd.

7. Wat is het relatieve belang van de factoren in de verklaring van verschillen en veranderingen in kwaliteit van leven?

Ook hier zijn geen specifieke verwachtingen geformuleerd. 
. 


\section{Het onderzoeksontwerp}

In dit hoofdstuk wordt op de eerste plaats de onderzoeksopzet beschreven. Vervolgens komen de keuze van de onderzoekseenheden, de selectie van patiënten, het onderzoeksprotocol, de verzameling van gegevens alsmede de operationalisatie van de variabelen aan de orde.

\subsection{De onderzoeksopzet}

De vraagstellingen in dit onderzoek betreffen de veranderingen in de kwaliteit van leven, in de continuïteit van zorg, in sociale steun en ziektegebonden kenmerken bij patiënten gedurende een bepaalde periode van het ziekteproces. Dit onderzoek is patiëntgebonden en heeft een longitudinale opzet. De follow-up periode bedroeg één jaar. In dat jaar vonden drie metingen aan de hand van interviews en schriftelijke vragenlijsten plaats. Omdat het ziek-zijn en de behandelingen gedurende de eerste maanden na de diagnose waarschijnlijk veel invloed hebben op het functioneren en welbevinden van patiënten vond de eerste meting plaats bij patiënten bij wie de diagnose korter dan drie maanden geleden was gesteld en/of die korter dan drie maanden geleden een behandeling hadden ondergaan of daar nog mee bezig waren. De tweede meting vond vier maanden na de eerste meting plaats, de derde meting een jaar na de eerste.

Het onderzoek werd, mede op grond van de geschiedenis van het project, in de regio Maastricht en in Noord-Limburg uitgevoerd. Als ingang in de gezondheidszorg is in Maastricht de tweedelijns-gezondheidszorg gekozen. De selectie van patiënten vond daar plaats via specialisten. In Noord-Limburg vormden de pathologen van het ziekenhuis te Venlo en de huisartspraktijken de schakel naar de patiënten. Er werd naar gestreefd om in elke locatie gegevens van 50 onderzoekseenheden te verzamelen. 


\subsection{De onderzoekseenheden}

De onderzoekseenheden werden gevormd door de patiënt en enkele relevante zorgverleners. Relevante zorgverleners zijn professionele zorgverleners van wie wordt verondersteld dat kankerpatiënten er regelmatig mee in contact komen: de behandelend specialist, de huisarts, de wijkverpleegkundige en in Maastricht, de ziekenhuisverpleegkundige. Naast de professionele zorgverleners zijn ook de centrale verzorgers uit de directe omgeving van de patiënten bij het onderzoek betrokken. De centrale verzorger is de persoon die volgens de patiënt de meeste steun geeft. Met het betrekken van deze relevante zorgverleners bij het onderzoek wordt getracht een beeld te krijgen van hoe de zorg wordt vormgegeven. Er kan dan worden nagegaan in welke mate zorg-en steunverleners de zorg op elkaar en op de patiënt afstemmen. In de onderstaande figuur wordt een volledige onderzoekseenheid, een casus, weergegeven.

Figuur 3, 1: Een volledige onderzoekseenheid

wijkverpleegkundige

ziekenhuisverpleegkundige centrale verzorger

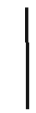

patiënt

huisarts

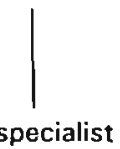

\subsection{Selectie van patiënten}

Om de generaliseerbaarheid van het onderzoek zo groot mogelijk te houden zijn patiënten geselecteerd met een mammacarcinoom, maag-darmcarcinoom, longcarcinoom, maligne lymphomen, prostaat-, nier- en blaascarcinomen, keelkanker of gynaecologische vormen van kanker. Het zijn allemaal vormen van kanker die vaak voorkomen. De patiëntenpopulatie is dus niet geselecteerd op grond van én specifieke vorm van kanker. De reden hiervoor is dat de problematiek van continuïteit van zorg zich in min of meerdere mate zal voordoen bij alle patiënten die langdurig en regelmatig contacten hebben met de gezondheidszorg. De keuze lijkt bovendien gerechtvaardigd omdat op grond van de literatuur verwacht wordt dat niet zozeer de specifieke diagnose als wel de ermee gepaard gaande ziektekenmerken, zoals stadium en prognose, van invloed zijn op de kwaliteit van het leven van patiënten (De Haes, 1988). Toch leek het ons niet zinvol om alle vormen van kanker mee te nemen in het onderzoek. Het is bijvoorbeeld de vraag of bij mensen met een kleine huidtumor die op gemakkelijke wijze te verwijderen is, sprake is van 
problemen met continuiteit van zorg of van veranderingen in het welbevinden of functioneren.

De patiënten die geselecteerd werden voor het onderzoek, moesten aan de volgende criteria voldoen:

- Er moet sprake zijn van een nieuwe maligne aandoening.

- De patiënt moet op de hoogte zijn van de diagnose.

- De patiënt moet bereid zijn om mee te werken aan het onderzoek.

Uitgesloten van het onderzoek werden:

- patiënten jonger dan 18 jaar

- patiënten die verblijven in een tehuis of instelling

- patiënten waarvan verwacht werd dat ze binnen een jaar zouden overlijden

- patiënten die niet in staat waren een interview te ondergaan (bijvoorbeeld doordat ze de Nederlandse taal niet machtig waren, doof, te ziek of afatisch waren).

De patiënten werden in Maastricht door de specialisten van het Academisch ziekenhuis, in Venlo door de pathologen van het Sint Maartens Gasthuis en door huisartsen in Noord-Limburg gescreend op de bovenstaande criteria.

\subsection{Het onderzoeksprotocol}

In september 1988 werd begonnen met het veldwerk in de regio Maastricht. Van tevoren is het onderzoeksprotocol getoetst door de medisch ethische commissie van het academisch ziekenhuis te Maastricht.

In Maastricht werden de patiënten als volgt geselecteerd:

De internisten-oncologen, een longarts en een k.n.o-arts van het academisch ziekenhuis Maastricht overhandigden tijdens het spreekuur op de polikliniek of bij opname een introductiebrief aan patiënten die aan de genoemde criteria voldeden. In deze brief werden het doel van het onderzoek, de methode en de tijdsduur beschreven en werd informatie met betrekking tot vertrouwelijkheid en eventuele vragen gegeven.

Aan deze brief zat een antwoordstrookje dat de patiënt kon terugsturen aan de onderzoeker om aan te geven of hij/zij bereid was om mee te doen of niet. De interviewers namen daarna zelf contact met bereidwillige patiënten op. Tijdens het interview met de patiënt werden de namen van de huisarts, specialist en eventueel de ziekenhuisverpleegkundige gevraagd en werd nagegaan of zij er bezwaar tegen hadden als deze zorgverleners voor het onderzoek benaderd werden. Tevens werd de patiënt verzocht de persoon uit zijn sociale netwerk te noemen van wie hij/zij de meeste steun ontving om zo ook deze in het onderzoek te betrekken. Uiteraard werd de patiënten verzekerd dat vertrouwelijke informatie die zij gaven niet zou worden uitgewisseld met de betrokken zorg- en steunverleners.

Aan het einde van het interview werden patiënten en zorgverleners nogmaals gevraagd of ze bereid waren om mee te werken aan de tweede c.q. derde meting. 
De selectie-procedure duurde in Maastricht 14 maanden. Dat was langer dan aanvankelijk werd verwacht. Bovendien bleek tijdens de procedure dat patiënten niet altijd aan de genoemde selectiecriteria voldeden. Er was, door procedurefouten van specialisten, sprake van selectie van enkele patiënten die al langer dan een jaar ziek waren en voor een recidief behandeld werden of die al geruime tijd in remissie waren.

Daarnaast deden zich in de selectieprocedure nog andere problemen voor:

- De risico-populatie (de populatie waarop de selectie betrekking had) was niet bekend.

- De selectie vond plaats door een gering aantal specialisten en was vooral afhankelijk van de keuzes van die specialisten zelf.

- Er was onvoldoende informatie over de non-respons van patiënten.

Hieruit kunnen we concluderen dat een bepaalde mate van selectiebias aanwezig is. In Maastricht zijn uiteindelijk achtendertig patiënten geselecteerd. In hoofdstuk 4 worden de kenmerken van deze patiënten nader beschreven.

Het onderzoeksprotocol met betrekking tot de selectie van patiënten in NoordLimburg werd gedeeltelijk aangepast om problemen, zoals die in Maastricht, te voorkomen.

De selectie van de patiënten in Noord-Limburg vond plaats met behulp van gegevens van de pathologen van het St.Maartens Gasthuis in Venlo en van huisartsen in de regio Noord-Limburg. Allereerst zijn de huisartsen en de specialisten aangeschreven en gevraagd hun medewerking te verlenen aan het onderzoek. Het ging om patiënten die onder behandeling waren bij een specialist uit het algemeen ziekenhuis in Venlo. Het ziekenhuis van Venlo is een streekziekenhuis met een pathologisch-anatomisch laboratorium voor de regio Noord-Limburg. De patholoog heeft de beschikking over een lijst met alle 'pathologisch-anatomische' uitslagen. Hij maakte een selectie van de patiënten die aan een van de eerder genoemde vormen van kanker leden en ging na wie de huisarts was. Een lid van de onderzoeksgroep, een huisarts, schreef deze geselecteerde huisartsen aan. Deze huisarts gaf, omdat hij de beschikking kreeg over de namen van de patiënten, nadrukkelijk een garantie van geheimhouding aan het ziekenhuis. Hij stuurde naar de huisartsen van de desbetreffende patiënten een brief met uitleg over het onderzoek en een introductiebrief voor de patiënt. De 'eigen' huisarts overhandigde de introductiebrief aan de patiënt. Net als in Maastricht stuurden patiënten de antwoordstrookjes terug naar de onderzoeker en namen de interviewers zelf contact op met patiënten en zorgverleners volgens de hierboven beschreven procedure. De interviewer had bij het eerste bezoek aan de patiënt de beschikking over de naam van de patiënt, het adres en het telefoonnummer. De patiënt had die gegevens zelf ingevuld op het antwoordstrookje.

De in Noord-Limburg gebruikte methode had in vergelijking met die in Maastricht, het voordeel dat we de beschikking hadden over gegevens van het totale cohort van 'nieuwe' oncologische patiënten in deze regio (ofwel de totale risicopopulatie) gedurende een bepaalde periode. Op deze wijze hadden we meer informatie ten aanzien van de non-responsgroepen. 
De namen van patiënten die niet meededen aan het onderzoek waren alleen bekend bij de huisarts in de onderzoeksgroep. Nadat onderzoek naar de non-respons was verricht, werden deze gegevens geanonimiseerd en werd de lijst met namen vernietigd. In hoofdstuk 4 worden de resultaten van de non-respons analyse weergegeven.

\subsection{De verzameling van gegevens}

De gegevens werden verzameld met behulp van interviews bij alle respondenten, patiënten, centrale verzorgers, specialisten, huisartsen en verpleegkundigen.

Bij vier patiënten en hun relevante zorg - en steunverleners werden proefinterviews afgenomen. Op grond van de opgedane ervaringen werden de vragenlijsten ingekort en de formuleringen van enkele vragen verbeterd. Een deel van de vragenlijsten, namelijk de Sickness Impact Profile en de Cancer Locus of Control schaal, werden bij de patiënten thuis achter gelaten. Na een korte uitleg konden de patiënten deze lijsten zelf invullen. Ze werden nadien door de interviewer opgehaald.

De interviews met patiënten duurden gemiddeld anderhalf uur, die met de centrale verzorgers drie kwartier en met de professionele zorgverleners een half uur.

De vragenlijsten bestonden voor een deel uit vragen met voorgestructureerde antwoordcategorieën en voor een deel uit open vragen. De antwoorden van de respondenten werden tijdens het interview door de interviewer genoteerd. De zeven interviewers waren allen ervaren in het omgaan met patiënten en kregen een interview-instructie. De vraaggesprekken werden bij patiënten en centrale verzorgers thuis afgenomen. Er werd gestreefd naar interviews zonder aanwezigheid van derden.

De professionele zorgverleners werden op hun werkplek bezocht. Een probleem was dat veel zorgverleners ondervraagd moesten worden over meer dan één patiënt. De interviewers brachten op deze wijze vaak veel tijd door in wachtkamers van huisartsen en specialisten. Ook voor de zorgverleners was het niet haalbaar om steeds een half uur van hun spreekuur te besteden aan het onderzoek. Besloten werd daarom om de specialisten, huisartsen en verpleegkundigen minstens éen keer mondeling te interviewen en de gegevens voor de latere metingen schriftelijk te verzamelen. De schriftelijke vragenlijsten werden geretourneerd in een gefrankeerde antwoordenvelop.

\subsection{Operationalisatie van de variabelen}

In deze paragraaf wordt per variabele weergegeven wat onze overwegingen zijn geweest bij de keuze van het gebruikte meetinstrument. In het algemeen hebben we gezocht naar instrumenten die in ander onderzoek valide en betrouwbaar zijn gebleken en bovendien door patiënten gemakkelijk waren te beantwoorden. Bij de variabelen die gemeten werden met behulp van schalen, worden de interne consistentie alsmede de door middel van factoranalyses verkregen dimensies weergegeven. De gemiddelde scores, spreidingsmaten en correlaties tussen de verschillende variabelen worden in de hoofdstukken 5 tot en met 8 beschreven. 
Znals in hoofdstuk 2 is beschreven, wordt kwaliteit van leven in dit onderzoek gedefinieerd als een subjectief, multidimensioneel begrip. Er zijn drie aspecten van kwaliteit van leven onderscheiden: het dagelijks (dis)functioneren als indicator voor sickness, klachten en globaal onwelbevinden als indicatoren voor illness. Deze aspecten zijn als volgt geoperationaliseerd:

\subsubsection{Het dagelijks (dis)functioneren}

Een instrument dat aan de gestelde criteria voldoet en dat een vrij brede operationalisatie geeft van het (dis)functioneren is de Sickness Impact Profile. Deze Sickness Impact Profile, kortweg de SIP genoemd, is een in de jaren zeventig in de Verenigde Staten ontwikkelde vragenlijst voor het meten van het disfunctioneren van zowel zieke als gezonde personen. Het is een algemeen 'kwaliteit van leven' instrument dat veel gebruikt wordt bij chronische patiënten. Uit Amerikaanse publikaties blijkt dat de SIP een betrouwbare en valide maat is voor het disfunctioneren ten gevolge van ziek-zijn (Bergner en Gilson, 1980; De Witte e.a., 1987, 1989). Spitzer (1987) en McDowell (1987) noemen de SIP een van de meest veelbelovende instrumenten om kwaliteit van leven te meten. De SIP beoogt veranderingen in gedrag en activiteiten te meten die naar het oordeel van de respondent samenhangen met zijn/haar gezondheidstoestand. Er wordt gevraagd naar feitelijke gedragingen en activiteiten in het dagelijks leven, los van ziektegevoelens en beleving van de aandoening.

De SIP bestaat uit 136 beweringen ofwel uitspraken over ziektegerelateerd disfunctioneren. De lijst kan door de patiënt zelf worden ingevuld of in een interview afgenomen worden. Gevraagd wordt alleen die uitspraken met ja te beantwoorden waarvan de patiënt zeker is dat ze zijn gedragingen op de dag van het interview beschrijven en waarvan hij denkt dat hij ze vanwege zijn gezondheidstoestand wel of niet meer doet. De 136 uitspraken worden onderverdeeld in 12 categorieën (zie bijlage A). Voor de 12 onderscheiden categorieën kunnen afzonderlijke scores berekend worden, evenals voor een tweetal dimensies: fysiek disfunctioneren (categorieën 3, 5, 7) en psychosociaal disfunctioneren (categorieën 2, 5, 8, 9). Daarnaast kan een totaalscore berekend worden. Aan de items zijn gewichten toegekend, vastgesteld door verschillende groepen beoordelaars (Carter, 1976). De scores worden berekend door de positief beantwoorde items (uitspraken die met ja zijn beantwoord) op te tellen en vervolgens te delen door de maximaal mogelijke score in die categorie en deze te vermenigvuldigen met 100 (De Witte, e.a.,1987, 1989; De Bruin, 1992). Op deze wijze ontstaat een relatieve score, te interpreteren als een percentage van de in die categorie maximaal mogelijke mate van disfunctioneren. Hoe hoger de score, hoe ernstiger de mate van disfunctioneren.

Naast een Zweedse, Britse en Duitse versie bestaat er ook een Nederlandse vertaling van de SIP. De resultaten tot nu toe wijzen erop dat de Nederlandse versie even betrouwbaar is als de Amerikaanse (Luttik e.a.,1987; De Witte e.a., 1987; De Bruin e.a., 1992). De Bruin e.a. (1992) concluderen uit een literatuurstudie naar validiteit en betrouwbaarheid van de SIP dat zowel de interne consistentie als de interraterbetrouwbaarheid en de test-hertest betrouwbaarheid goed zijn. De betrouwbaar- 
heid van de in interviews afgenomen lijsten blijkt hoger dan van de door patiënten zelf ingevulde lijsten. Maar ook bij de zelf ingevulde lijsten blijkt Cronbach's alpha zeer acceptabel, namelijk 0.87 (Bergner, 1981). De constructvaliditeit en de discriminerende validiteit van de SIP lijken in het algemeen voldoende (De Bruin e.a., 1992).

Ook in ons onderzoek was Cronbach's alpha voor de totaalscore hoog, variërend van $0.91-0.96$ voor de drie metingen. De categorie 'werken' is buiten beschouwing gelaten omdat de meerderheid van de patiënten $(80 \%)$ geen beroepsarbeid meer verricht vanwege vervroegd uittreden, pensionering of omdat men huisvrouw is. Voor de elf overblijvende categorieën zijn Cronbach's alpha's berekend. Deze zijn in tabel 3.1 voor de eerste meting weergegeven. De Cronbach's alpha's bij de vervolgmetingen wijken nauwelijks van de eerste meting af. De interne consistentie van de categorieën 'slapen' en 'emotioneel gedrag' zijn matig, voor de andere categorieën is de alpha hoog tot zeer hoog. Besloten werd om het aantal variabelen zo beperkt mogelijk te houden en in verdere analyses alleen de totaalscore van de SIP te hanteren. Alleen in hoofdstuk 5 komen de scores op de categorieën aan de orde.

Tabel 3.1 Categorieën van de SIP en hun interne consistentie, Cronbach's Alpha $(n=117)$.

categorie:

aantal

items

alpha

1. Slapen/rusten

\section{7}

9

2. Emotioneel functioneren

3. Lichaamsverzorging

4. Huishoudelijke activiteiten

23

10

5. Mobiliteit

10

6. Sociale interactie

7. Lopen

8. Alertheid

9. Communicatie

10.Recreatie/vrije tijd

11. Eten

\subsubsection{Klachten}

Het voorkomen van klachten is gemeten door middel van de 'Klachtenlijst voor Kankerpatiënten', ook wel bekend onder de naam 'Rotterdam Symptom Checklist' (de Haes, 1983). Deze klachtenlijst beoogt het door patiënten ervaren welbevinden bij verschillende vormen van kanker, bij verschillende stadia in het ziekteproces en bij verschillende vormen van therapie te onderscheiden (Van den Borne en Pruyn, 1985). De lijst is door patiënten zelf makkelijk in te villen of in een interview te beantwoorden. In de lijst wordt gevraagd naar de mate waarin de patiënt de afgelopen week last heeft gehad van bepaalde klachten. Het betreft een lijst met 27 items waarop door middel van een vierpunts-schaal - 'helemaal niet- een beetje-nogal 
-heel erg" - geantwoord kan worden. Aan de lijst wordt een lichamelijke en een psychische dimensie onderscheiden (De Haes, 1983,1988; Van den Borne en Pruyn, 1985). De validiteit en betrouwbaarheid van de lijst zijn bevredigend (De Haes, 1983, 1988).

Ook in ons onderzoek konden door middel van een principale-componentenanalyse twee dimensies worden onderscheiden. De gevonden factorstructuur is in hoofdlijnen goed vergelijkbaar met de resultaten van eerder onderzoek, zoals dat van De Haes (1988). In tabel 3.2 wordt de tweefactor-oplossing na principale componentenanalyse weergegeven. De principale componenten analyse is uitgevoerd met de gegevens van alle respondenten voor de drie metingen gezamenlijk. Gezien het kleine aantal respondenten was het niet mogelijk om voor de drie metingen aparte analyses te doen.

Tabel 3.2 Principale Componenten analyse van de Klachtenlijst (27 items). Factorladingen $(>.30)$, na varimax rotatie $(n=263)$.

\begin{tabular}{|c|c|c|}
\hline & factor 1 & factor 2 \\
\hline gebrek aan eetlust(I) & & .67 \\
\hline prikkelbaarheid $(p)$ & .52 & \\
\hline moeheid (I) & .40 & .58 \\
\hline piekeren (p) & .77 & \\
\hline pijnlijke spieren (I) & .42 & \\
\hline neerslachtigheid (p) & .76 & \\
\hline futloosheid (I) & .39 & .62 \\
\hline pijn onder in rug (l) & .41 & \\
\hline zenuwachtigheid (p) & .53 & \\
\hline misselijkheid (I) & & .72 \\
\hline wanhopig over toekomst (p) & .73 & \\
\hline slapeloosheid (p) & - & \\
\hline hoofdpijn (p) & & .38 \\
\hline duizeligheid (I) & & .35 \\
\hline mond of slikpiin (I) & & .57 \\
\hline angst $(p)$ & .75 & \\
\hline verminderde sex, belangs. (I) & .46 & \\
\hline maagzuur/oprispingen (I) & & .38 \\
\hline rillerigheid (I) & & .54 \\
\hline tintelingen (I) & .38 & \\
\hline buikpijn (I) & & .43 \\
\hline gespannen (p) & .79 & \\
\hline haaruitval (I) & & .31 \\
\hline brandende ogen (I) & & .32 \\
\hline moeilijk concentreren $(p)$ & & .36 \\
\hline kortademigheid (I) & & .35 \\
\hline droge mond (I) & & .49 \\
\hline
\end{tabular}

Om te controleren of er sprake was van stabiliteit van de factorstructuur is voor de eerste meting nog eens apart een principale componenten analyse gedaan. Deze leverde een vergelijkbare structuur op (zie bijlage B). 
De totaal verklaarde variantie is $32.4 \%$. De eerste factor verklaart $24.1 \%$ van de variantie, factor 2 verklaart $8.4 \%$. Deze factoren verwijzen naar twee goed te onderscheiden dimensies; psychische klachten en lichamelijke klachten.

Op de factor psychische klachten laden de volgende items het hoogst: je gespannen voelen (.79), piekeren (.77), neerslachtigheid (.76) en angst (.75).

Op de factor lichamelijke klachten zijn de hoogst ladende items: misselijkheid (.72), gebrek aan eetlust (.67), futloosheid (.62) en moeheid (.58).

In eerder onderzoek van De Haes (1988), behoorden de met (l) gemerkte items bij de lichamelijke factor en de met (p) gemerkte items bij de psychische factor. Sommige klachten zijn, op grond van eerdere bevindingen van onderzoek bij kankerpatiënten, bij de lichamelijke factor opgenomen, terwijl ze in onze analyse meer psychisch gekleurd lijken of andersom. Het gaat om zes items: pijnlijke spieren, pijn in de rug, hoofdpijn, verminderde seksuele belangstelling, tintelingen en moeilijk kunnen concentreren. Dit blijken items te zijn die een relatief lage lading op de factoren hebben. Omwille van de vergelijkbaarheid met ander onderzoek en omdat onze analyse goed overeenkomt met de indeling in de oorspronkelijke lijst, zoals De Haes hem gebruikt heeft, is besloten de gebruikelijke indeling over te nemen. Voor de twee dimensies zijn somscores berekend. De interne consistentie van deze twee subschalen is hoog. De Cronbach's alpha voor de dimensie lichamelijke klachten varieerde bij de drie metingen tussen .76 en .81 en voor de dimensie psychische klachten tussen .77 en .81 .

\subsubsection{Het globale (on/welbevinden}

Naast de klachtenlijst zijn nog enkele globale maten voor het welbevinden gebruikt. $\mathrm{Ze}$ geven aan hoe het met de patiënt in het algemeen gaat. Bij de keuze voor een instrument voor de globale benadering van kwaliteit van leven is aansluiting gezocht bij ander onderzoek naar kwaliteit van leven, zoals dat van De Haes (1988), De Witte (1989) en Terpstra (1990).

De volgende vragen werden gesteld:

- Hoe tevreden bent U nu over Uw leven ?

- Hoe voelt U zich nu alles bij elkaar genomen ?

De correlaties tussen deze maten variëren op de drie metingen in ons onderzoek tussen .49 en .56. Opgemerkt moet worden dat de eerder genoemde onderzoekers een zeven-puntsschaal gebruikten terwijl wij in ons onderzoek een vijf-puntsschaal gebruiken omdat dat beter past bij de andere gebruikte vijf-puntsschalen in de vragenlijst. In het onderzoek van de Witte e.a. (1989) en dat van Terpstra (1990) bleken de correlaties hoger, namelijk minimaal .78. Op grond de bevindingen in deze andere onderzoeken zijn beide maten door ons samengevoegd tot én globaal oordeel over het (on)welbevinden.

Samengevattend onderscheiden we dus 4 maten voor kwaliteit van leven: de totaalscore van de Sickness Impact Profile als maat voor disfunctioneren, lichamelijke klachten, psychische klachten en een globale maat voor (on)welbevinden. 
Een belangrijke groep van onafhankelijke variabelen heeft betrekking op organisatie gerichte afstemming van zorg (of coördinatie) en patiëntgerichte afstemming, die zijn samengevat in de term continuïteit van de professionele zorgverlening.

Bij de operationalisatie van continuïteit van de professionele zorgverlening was het niet altijd mogelijk om bestaande meetinstrumenten te gebruiken. Gepoogd is zoveel mogelijk aansluiting te zoeken bij de literatuur en bij vergelijkbaar onderzoek naar afstemming van zorg (De Witte, 1991; Engelsman, 1988; Van der Wouden, 1986; Coolen, 1986).

Zoals in hoofdstuk twee is beschreven, kunnen aan continuïteit van zorg een structureel, een cultureel-, een tijds- en een doelstellingaspect onderscheiden worden. De operationalisatie van deze aspecten wordt hieronder beschreven.

\subsubsection{Structurele aspecten van het professionele netwerk}

Structurele aspecten van het professionele netwerk hebben betrekking op de grootte van het netwerk en de onderlinge contacten van professionele zorgverleners. Deze factoren zijn indicatoren voor de afstemming van de zorg. Een groot professioneel netwerk met weinig onderlinge contacten zal de kans dat de zorg gecoördineerd verloopt, verkleinen.

Aan de patiënten zijn de volgende vragen gesteld:

- "Kunt U aangeven met welke van de volgende professionele zorgverleners U de laatste drie maanden contact heeft gehad ?"

- "Indien U contact had met een van deze zorgverleners, hoe vaak was dat dan ?"

Vervolgens werden 17 verschillende professionele zorgverleners genoemd (o.a specialist, huisarts, wijkverpleegkundige, gezinshulp, pastor en alternatieve genezer) van wie de patiënt kon aangeven of hij daar al dan niet contact mee had gehad. Op basis van deze gegevens is de grootte van het professionele zorgnetwerk berekend. Deze grootte is vastgesteld door het aantal zorgverleners te tellen met wie de patiënt de afgelopen drie maanden contact had gehad.

Onderlinge contacten zijn bepaald door aan de geïnterviewde professionele zorgverleners te vragen of ze in de afgelopen 3 maanden contact hadden gehad met andere betrokken zorgverleners en of dat contact structureel of incidenteel was. Alle contacten zijn meegerekend: face to face, schriftelijke en telefonische contacten. Het ging om bilaterale contacten. Als slechts één van twee partijen aangaf contact te hebben gehad met de ander werd dit contact meegerekend. De vraag of de contacten incidenteel of structureel waren, is niet geanalyseerd vanwege een zeer scheve verdeling: bijna alle contacten waren incidenteel. Een beperking bij het operationaliseren van deze variabele is dat er geen gegevens beschikbaar zijn over contacten van andere dan de geïnterviewde zorgverleners. Het is echter niet aannemelijk dat er veel contacten plaats vinden buiten de geïnterviewde disciplines om. 
Het creëren van een maat voor 'onderlinge contacten' heeft in verschillende stappen plaatsgevonden. Er zijn aan de hand van het aantal contacten zes categorieën patiënten gevormd: patiënten met twee, drie, vier, vijf, zes of zeven en meer verschillende zorgverleners. Aan de hand van de frequentieverdeling van het aantal onderlinge contacten binnen iedere categorie is gedichotomiseerd $(0=$ geen onderlinge contacten) $(1=$ wel onderlinge contacten). De verschillende patiëntencategorieën die hierboven beschreven werden, waren echter niet onderling vergelijkbaar. Bij patiënten met veel verschillende zorgverleners is de kans op onderlinge contacten groter dan bij patiënten die met minder professionals contact hadden. We hebben besloten het contact tussen huisarts en specialist als variabele te gebruiken, omdat vrijwel alle patiënten met deze twee zorgverleners contact hebben, omdat contact tussen deze twee een belangrijke bijdrage levert aan de overdracht van zorg van de tweede naar de eerste lijn en vice versa en vooral omdat andere contacten nauwelijks voorkomen. Het betreft een dichotome variabele; wel of geen contact tussen huisarts en specialist.

\subsubsection{Cultureel aspect: taakovereenstemming}

Om te komen tot samenwerking is een redelijke mate van taakafbakening noodzakelijk (Van Beek e.a., 1984; Van der Wouden e.a., 1986; Engelsman, 1988). Om de taakafbakening te operationaliseren zijn de verschillende betrokken zorgverleners gevraagd naar hun taakopvattingen.

Aan alle professionele zorgverleners (specialist, huisarts, wijkverpleegkundige of ziekenhuisverpleegkundige) zijn, alleen bij de eerste meting, dertien taken en werkzaamheden voorgelegd die deel uit kunnen maken van de zorgverlening aan patiënten (zie bijlage C). Deze lijst met taken is eerder gebruikt door de Witte (1991) in zijn onderzoek naar continuïteit van zorg bij revalidatiepatiënten en is facevalide. Enkele voorbeelden van de genoemde taken zijn:

- De begeleiding van de patiënt tijdens opname.

- Het geven van medische informatie over de ziekte en behandelingsmogelijkheden.

- Begeleiding van gezinsleden ten aanzien van eventuele problemen ten gevolge van het ziek-zijn van de patiënt.

Aan de zorgverleners is gevraagd of zij de taak primair tot hun eigen verantwoordelijkheid rekenden dan wel tot de verantwoordelijkheid van een andere zorgverlener. Hierbij konden zij kiezen uit de huisarts, de specialist, de wijkverpleegkundige, de ziekenhuisverpleegkundige of een 'andere zorgverlener'.

Voor de berekening van de mate van overeenstemming zijn alleen paren van huisartsen en specialisten gevormd, omdat het aantal deelnemende verpleegkundigen te gering bleek (zie hoofdstuk vier). Het aantal taken waarbij 'paren' zorgverleners hetzelfde antwoord geven, is gebruikt als maat voor overeenstemming. De score kan op deze wijze variëren tussen 0 (over geen enkele taak overeenstemming) tot 13 (over alle taken overeenstemming). Het aantal taken waarover overeenstemming bestaat wordt als variabele gebruikt in verdere analyses. 


\subsubsection{Tijdsaspect}

Bij de mate van afstemming van de zorg in de tijd gaat het erom dat het zorgproces zo continu mogelijk verloopt, parallel aan de ontwikkelingen die de patiënt doormaakt tijdens het ziekteproces. Uit de literatuur blijkt dat het contact met steeds dezelfde arts van invloed is op de tevredenheid van patiënten. Verwacht wordt dat als patiënten steeds door dezelfde persoon geholpen worden, de continuïteit van de zorgverlening beter gewaarborgd is, de zorgbehoeften eerder onderkend worden en patiënten daardoor tevredener zijn. Daarnaast is ook de overdracht tussen de disciplines van belang. Ziekenhuisopnamen en ontslag zijn episodes in het ziekteproces waarin de continuïteit gewaarborgd zou moeten zijn. Tijdens de drie patiënten-interviews zijn daarom de volgende vragen gesteld:

1. Wordt U steeds door dezelfde specialist geholpen in de polikliniek ? (ja/nee)

2. Toen $U$ werd opgenomen, was er toen iemand die $U$ voorbereidde op wat er tijdens de opname ging gebeuren? (ja/nee)

3. Kreeg U tijdens de opname steeds dezelfde arts aan Uw bed? (ja/nee)

4. a.Toen $U$ ontslagen werd uit het ziekenhuis, kwam er toen een professionele zorgverlener (huisarts, wijkverpleegkundige) bij U thuis op bezoek ? (ja/nee) b. Hoeveel tijd zat er tussen het ontslag uit het ziekenhuis en het eerste contact met deze zorgverlener(s)? (Hierbij kon men kiezen uit 5 antwoordcategorieën: minder dan een week- 1 tot 2 weken - 2 tot 4 weken- meer dan een maandhelemaal niet).

Het blijkt dat deze vragen zeer weinig onderlinge samenhang vertonen. De interne consistentie van deze items is zeer laag, variërend van .19 tot .37 bij de drie metingen. Bovendien zijn er tijdens de tweede en derde meting zeer weinig mensen recent opgenomen geweest, respectievelijk $17 \%$ (11) en $9 \%$ (6) van alle patiënten. De vragen 2, 3 en 4 leverden daarom bij de tweede en derde meting te weinig bruikbare informatie op. De operationalisatie van het tijdsaspect is derhalve niet goed gelukt. Twee variabelen worden meegenomen in verdere analyse:

a. het al dan niet behandeld worden door dezelfde specialist gedurende de hele onderzoeksperiode en $\mathrm{b}$. het al dan niet ontvangen van nazorg door een huisarts en/of wijkverpleegkundige na ontslag uit het ziekenhuis, maar ook later in de ziekteperiode. Bij de eerste meting is expliciet gevraagd naar bezoeken van deze zorgverleners. Bij de vervolgmetingen is geput uit de gegevens met betrekking tot het structurele aspect. Hieruit kon immers worden afgeleid of patiënten gedurende de onderzoeksperiode contacten bleven onderhouden met de huisarts en wijkverpleegkundige.

\subsubsection{Doe/stellingsaspect}

Bij het doelstellingaspect gaat het vooral om de mate waarin de zorg is afgestemd op de zorgbehoeften en de leefwereld van de patiënt. Om dit te meten zijn twee indicatoren gebruikt: de tevredenheid van patiënten en van centrale verzorgers over 
de zorg en de mate van afstemming tussen zorgverleners en patiënten wat de zorgbehoeften betreft.

Bekend is dat 'oudere' patiēnten, die afhankelijk zijn van de zorg van anderen, geneigd zijn om tevreden te zijn over de zorg die zij ontvangen (Visser, 1984). Daarom is in dit onderzoek ook het oordeel van de centrale verzorger gevraagd. Deze heeft wellicht een meer objectief oordeel over de geboden zorg dan de patiënt zelf. Aan patiënten en centrale verzorgers is gevraagd hoe tevreden ze zijn over de totale hulpverlening die de patiënt in de periode, voorafgaande aan de meting, ontvangen heeft. Ze konden scoren op een vijf-puntsschaal, lopend van zeer ontevreden tot zeer tevreden. De scores van patiënt en centrale verzorger zijn opgeteld en gemiddeld. Indien alleen de patiënt of alleen de centrale verzorger zijn/haar oordeel had gegeven, werd deze ene score als maat genomen. Dit kwam slechts enkele malen voor.

De vragen naar tevredenheid werden verder uitgesplitst naar enkele afzonderlijke zorgverleners (huisarts, specialist, wijkverpleegkundige en ziekenhuisverpleging). Met behulp van een vijf item-schaal, die eerder door Engelsman e.a. (1987) werd gebruikt, is patiënten gevraagd naar de tevredenheid over de tijd die de zorgverlener aan hen besteedde, over zijn/haar deskundigheid, over de steun die de patiënt van de betrokken zorgverlener kreeg, over de informatie en over de persoonlijke belangstelling. Voor het meten van de tevredenheid over de specialist, huisarts, wijken ziekenhuisverpleegkundige werd steeds deze schaal van vijf vragen gebruikt.

De Cronbach's alpha's van de genoemde schalen zijn hoog (variërend tussen .84 en 91). De vijf vragen konden derhalve worden opgeteld tot eén maat voor tevredenheid per betrokken professionele zorgverlener: tevredenheid over de specialist, tevredenheid over de huisarts, tevredenheid over de wijkverpleegkundige en tevredenheid over de ziekenhuisverpleging. Bij de tweede en derde meting werden de vragen met betrekking tot de ziekenhuisverpleegkundige en de wijkverpleegkundige weggelaten vanwege het veelal ontbreken van deze zorgverleners in het zorgproces.

Bij de operationalisatie van overeenstemming over zorgbehoeften was het uitgangspunt dat er een bepaalde mate van overeenstemming zou moeten bestaan tussen de beoordeling van zorgbehoeften door patiënt en door zorgverlener, als de zorgverlener zijn zorg ook daadwerkelijk wil aanpassen aan de ervaren behoeften van de patiënt. Zorgbehoeften worden in dit onderzoek beschouwd als aspecten waarbij men afhankelijk is van de zorg van anderen (Atis, 1988). Gekozen werd voor een aantal zorgbehoeften waarvan we verwachten dat ze essentieel zijn voor kankerpatiënten. Aan patiënten is gevraagd in welke mate ze zorg nodig hadden ten aanzien van de volgende activiteiten of problemen:

- activiteiten van het dagelijks leven (wassen, aankleden, toilet bezoek etc.)

- huishoudelijke activiteiten

- het doen van (lichamelijke) oefeningen n.a.v. gevolgen van de ziekte/behandeling

- medicijngebruik

- het verwerken van de ziekte

- problemen met anderen ten gevolge van de ziekte 
Respondenten konden scoren op een vijf-puntsschaal, lopend van "helemaal geen hulp nodig" tot "zeer veel hulp nodig". Het laatste item, "problemen met anderen ten gevolge van de ziekte", werd geëlimineerd vanwege een te scheve verdeling. Bijna niemand had behoefte aan zorg op dit gebied.

Ook aan professionele zorgverleners en centrale verzorgers is gevraagd of patiënten ten aanzien van deze aspecten zorg nodig hadden, zodat de mening van alle zorgen steunverleners en die van de patiënt met elkaar vergeleken kon worden.

Om een maat voor overeenstemming te creëren zijn de scores van de patiënten per item gedichotomiseerd (wel/geen zorgbehoefte) en vergeleken met de scores van de professionele zorgverleners en centrale verzorgers. Er zijn paren gevormd van centrale verzorgers en patiënten, van huisartsen en patiënten en van specialisten en patiënten. De gegevens met betrekking tot de verpleegkundigen hebben we hier buiten beschouwing gelaten vanwege het geringe aantal deelnemende verpleegkundigen (zie hoofdstuk 4). Het aantal zorgbehoeften waarbij 'paren' (zorgverlener patiënt) hetzelfde antwoord gaven is gebruikt als maat voor overeenstemming. De score kan op deze wijze voor elk geanalyseerd paar variëren van 0 tot 5 , ( 0 betekent dat over geen enkele zorgbehoefte overeenstemming bestaat -5 betekent overeenstemming over alle vijf de zorgbehoeften).

\subsubsection{Operationalisatie van sociale steun}

Zoals in hoofdstuk twee is beschreven onderscheiden we aan sociale steun twee aspecten: structurele kenmerken van het sociale netwerk en functionele- of doelstellingskenmerken van sociale steun.

\subsubsection{Structurele aspecten van het sociale netwerk}

Wat betreft de structuur van het sociale netwerk zijn gegevens over de grootte, de samenstelling en de dichtheid van het netwerk verzameld. Bij de operationalisatie van deze structurele aspecten is gebruik gemaakt van een instrument dat ontwikkeld is voor het al eerder genoemde onderzoek van De Witte (1991) en een onderzoek naar sociale netwerken van chronisch zieken (Janssen, 1992). Het instrument bleek in die projecten goed te voldoen. Het is voor een deel gebaseerd op elementen van andere valide instrumenten, zoals de Norbeck Social Support Questionnaire (Norbeck, 1981).

Bij elke meting is de patiënt gevraagd de mensen te noemen met wie hij/zij persoonlijke banden onderhield en die voor hem/haar belangrijk waren. Hierbij is een maximum gesteld van 20 personen.

Vervolgens zijn over elk van de genoemde personen onder andere de volgende vragen gesteld:

- In welke relatie staan de door U genoemde personen tot U ? (partner, kind, vriend, buur etc.)

- Is de genoemde persoon een man of vrouw ?

- Hoe lang kent U de genoemde persoon ? 
Daarnaast is de volgende vraag gesteld:

- Kunt U vertellen welke van de mensen die U genoemd heeft elkaar kennen ? Zijn het als het ware allemaal losse individuen of zijn er groepen in te onderscheiden ? Hierbij konden de respondenten kiezen uit acht mogelijkheden variërend van: " $\mathrm{Ze}$ kennen elkaar geen van allen" (lage dichtheid) tot "Iedereen kent iedereen en ze hebben vaak contact met elkaar" (hoge dichtheid).

Op basis van deze vragen is een beperkt aantal variabelen berekend:

- de grootte van het persoonlijk netwerk: het aantal genoemde personen.

- de samenstelling van het netwerk: een onderscheid werd gemaakt tussen familieleden en niet familieleden. Als maat is het percentage 'familieleden' van het totale netwerk gebruikt.

- de dichtheid van het netwerk: op grond van de frequentieverdeling hebben we een onderscheid gemaakt tussen mensen met een zeer dicht netwerk (waarin iedereen elkaar kent en veel contacten heeft) en patiënten met een minder dicht netwerk.

\subsubsection{Doelstellingskenmerken van sociale steun}

Het gaat bij sociale steun niet alleen om structurele kenmerken van het netwerk maar ook om de kwaliteit van de relaties, de functionele- of doelstellingskenmerken. Zoals in hoofdstuk twee is beschreven, bestaan er verschillende soorten sociale steun. In veel studies richt men zich tot drie vormen: emotionele, informatieve en instrumentele of praktische steun (Dunkel -Schetter, 1984 ; Winnubst e.a., 1987 ; Ros, 1989). Informatieve steun is vooral van belang als die gegeven wordt door professionele hulpverleners en wordt in deze context buiten beschouwing gelaten.

Aan de patiënten zijn over elke genoemde persoon in zijn persoonlijk netwerk de volgende vragen gesteld:

- In welke mate neemt $U$ deze persoon in vertrouwen, bijvoorbeeld m.b.t zorgen over kinderen, uw ziekte, financiële problemen etc ?

- Hoeveel praktische hulp krijgt u van deze persoon (bijvoorbeeld boodschappen doen, op kinderen passen, vuilniszakken buiten zetten etc.) ?

- Wordt U door deze persoon in vertrouwen genomen als hij problemen heeft ?

- Hoeveel praktische hulp geeft U aan de door U genoemde persoon?

Bij elk van deze vragen konden respondenten, voor elk netwerklid dat ze genoemd hadden, op een vijfpuntsschaal scoren van "helemaal niet" tot "zeer veel" c.q. "helemaal niet" tot "zeer vaak".

Op basis van deze vragen konden de volgende variabelen worden berekend.

- De gemiddelde hoeveelheid ervaren emotionele steun per netwerklid. Deze maat is berekend door de totale hoeveelheid ervaren steun van alle netwerkleden bij elkaar op te tellen en te delen door het aantal netwerkleden.

- De gemiddelde hoeveelheid ervaren praktische steun per netwerklid. Deze maat is berekend door de totale gekregen steun van het netwerk te delen door het aantal netwerkleden.

- Wederkerigheid van de emotionele steun en wederkerigheid van de praktische steun. De wederkerigheid is berekend door de totale hoeveelheid gegeven steun te 
delen door de totale hoeveelheid ervaren steun. Dit is voor emotionele en praktische steun apart gedaan.

\subsubsection{Operationalisatie van ziektekenmerken en behandeling}

Voor het verkrijgen van medische gegevens met betrekking tot kenmerken van de ziekte en de behandeling zijn huisartsen en specialisten gevraagd de volgende vragen te beantwoorden:

- Kunt U het type kanker noemen waar de patiënt aan lijdt, wat is de diagnose (open vraag)?

- In welk stadium bevindt de ziekte zich ?

Hierbij is, aan de hand van TNM classificatie, een onderscheid gemaakt tussen patiënten zonder en met metastasen (dichotome variabele).

- Wat is volgens $\mathrm{U}$ de overlevingsprognose?

( 5 punts-schaal zeer goed - zeer slecht).

- Wanneer is de diagnose gesteld ?

De ziekteduur is berekend in maanden.

- Welke behandeling heeft de patiënt ondergaan ?

(operatie, chemotherapie, bestraling, of een combinatie van deze).

De antwoorden van huisartsen en specialisten met betrekking tot de overlevingprognose zijn bij elkaar opgeteld en gemiddeld. Informatie met betrekking tot het stadium van de ziekte werd nagezocht met behulp van het medisch dossier van de huisarts en/of de specialist.

\subsubsection{Operationalisatie van sociale positie}

Als indicatoren voor de sociale positie van de patiënten werden de volgende sociaaldemografische kenmerken verzameld: geslacht, leeftijd, sociaal-economische status: en burgerlijke staat.

Sociaal-economische status (ses) werd geoperationaliseerd door te vragen naar de hoogstgenoten opleiding, het laatst uitgeoefende beroep en dat van de partner. Met behulp van de beroepenklapper van het Instituut voor Toegepaste Sociologie (1975) zijn de beroepen gecodeerd op een zevenpunts-schaal. Het hoogst scorende beroep (dat van de patiënt of partner) is als maat voor beroep genomen. Hiervan werden zscores berekend, evenals van de genoten opleiding. Deze z-scores werden bij elkaar opgeteld om één maat voor sociaal-economische status te creëren.

$\mathrm{Bij}$ burgerlijke staat werd een onderscheid gemaakt tussen mensen die met een partner samen leven en mensen die alleen leven (gescheiden, nooit gehuwd en weduw(e)naar). 


\subsubsection{Operationalisatie van beheersingsoriëntatie}

De beheersingsoriëntatie is gemeten met behulp van de Locus of Controll-schaal voor kankerpatiënten (CLOC). Deze schaal is ontwikkeld om het ziektegedrag van kankerpatiënten te kunnen voorspellen. Door middel van factoranalyse konden drie dimensies worden geïdentificeerd: interne controle ten aanzien van het ontstaan van de ziekte, interne controle ten aanzien van het verloop van de ziekte en religieuze controle (Pruyn e.a., 1988). Er worden vier categorieën gehanteerd: geheel mee oneens - enigszins mee oneens -enigszins mee eens - geheel mee eens.

Op de gegevens van ons eigen onderzoek werd eveneens een factoranalyse gedaan. Bij principale componentenanalyse, met een gedwongen beperking tot drie factoren kwam een vergelijkbare factorstructuur naar voren. In bijlage $D$ is het resultaat van deze analyse weergegeven.

De totaal verklaarde variantie bedraagt $46.9 \%$. Factor 1 verklaart $21.5 \%$, factor 2 verklaart $14.1 \%$ en factor 3 verklaart $11.3 \%$ van de variantie.

De eerste factor wordt voornamelijk bepaald door de volgende items:

2. Ik oefen zelf een sterke invloed uit op het verloop van mijn ziekte.

17. Door gezond te leven oefen ik invloed uit op het verloop van mijn ziekte.

20. Door te vechten tegen mijn ziekte kan ik het verloop ervan beïnvloeden.

Pruyn e.a. noemen deze dimensie interne oriëntatie ten aanzien van het verloop. Deze omschrijving is ons inziens niet juist omdat ook items die meer passen bij een externe oriëntatie op deze factor laden. De vraag is of het hier niet meer gaat om een factor 'beïnvloedbaarheid van het verloop van de ziekte', een dimensie die weergeeft of mensen denken dat 'iets' of zij dat nu zelf zijn, hun arts, familie en/of vrienden, van invloed is op het verloop van hun ziekte.

De tweede factor is duidelijker te benoemen, namelijk als religieuze oriëntatie: de invloed van het geloof en God op het verloop en het ontstaan van de ziekte.

Deze factor wordt bepaald door de items:

3. Dat ik ziek ben geworden komt deels doordat God dat zo heeft beschikt.

9. God oefent een sterke invloed uit op het verloop van mijn ziekte.

16. Mijn geloof heeft invloed op het verloop van mijn ziekte.

De derde factor kan worden benoemd als interne oriëntatie ten aanzien van het ontstaan van de ziekte. Bepalend voor deze factor zijn de items:

21. Dat ik ziek ben geworden, ligt voornamelijk aan mezelf.

6. Dat ik ziek ben geworden, heeft te maken met mijn leefpatroon.

12. Dat ik ziek ben geworden, is gedeeltelijk mijn eigen schuld.

In verband met de vergelijkbaarheid houden we de items aan die ook in het onderzoek van Pruyn (1988) zijn gebruikt. De eerste dimensie 'beĩnvloedbaarheid van het verloop', bestaat uit zeven items, de 'religieuze dimensie' uit drie items en de dimensie 'interne oriëntatie ten aanzien van het ontstaan' bestaat ook uit drie items. De Cronbach's alpha's zijn in alle drie de metingen hoog, zoals in tabel 3.3 te zien is. 

meetmomenten $(n=87)$.

t1 $(n=87)$

t2 $(n=64)$

$\mathrm{t} 3(n=58)$

Beinvloedbaarheid verloop

Religieuze oriëntatie .80

Interne oriëntatie ontstaan

\subsection{Overzicht van de variabelen}

Tot slot wordt in tabel 3.4 een overzicht van alle gemeten variabelen bij de drie metingen gegeven. Daarbij wordt aangegeven op welk meetmoment de variabele gemeten is. 
Tabel 3.4 Overzicht van gebruikte variabelen bij de drie metingen.

10 meting

\section{Kwaliteit van leven}

Disfunctioneren:

- Sip

$\mathrm{X}$

X

X

Onwelbevinden:

- Lichamelijk klachten

$x$

$x$

- Psychische klachten

- Globaal onwelbevinden

$x$

$x$

$x$

$x$

$x$

\section{Continuïteit van Zorg}

Structuur:

- Grootte professioneel netwerk

- Onderlinge contacten ha-sp

Cultuur:

- Taakovereenstemming

Tijd:

- Contact dezelfde arts

- Zorgverlening na ontslag

Doelstelling:

- Tevredenheid

- Overeenstemming zorgbehoeften

Sociale steun

- Grootte sociaal netwerk

- Dichtheid

- Samenstelling netwerk

- Praktische steun

- Emotionele steun

- Wederkerigheid steun

Ziektekenmerken en behandeling

- Aard aandoening

- Stadium

- Prognose

- Duur

- Behandeling

Sociale positie

- Geslacht

- Leeftijd

- Burgerlijke Staat

- Sociaal-economische status

Beheersingsoriěntatie

- Beinvloedbaarheid verloop

- Interne controle ontstaan

- Religieuze oriēntatie $x$

$x$

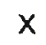

$x$

$x$

$x$

$x$

$x$

$x$

$x$

$x$

$x$

$\mathrm{X}$

$x$

$x$

$x$
$x$

$x$
$x$

$x$

$x$

$x$

$x$

$x$

$x$

$x$

$x$

$x$

$x$

$x$

$x$

$x$

$x$

$x$

$x$

$\mathrm{X}$

$\mathrm{X}$

$x$

$x$

$x$

$x$

$x$

$x$

$x$
$x$
$x$

X

-

$x$

$x$

$x$

$x$

X

$x$

$x$

$\mathrm{X}$ $x$

$x$

$x$ $x$

$x$

$x$ 



\section{Selectie van de onderzoekseen- heden}

In dit hoofdstuk wordt het respons c.q. non-responsgedrag van de onderzoeksgroepen behandeld. Op de eerste plaats zal een beschrijving worden gegeven van de opbouw van de patiëntengroep in Noord-Limburg (4.1). Hierbij besteden we aandacht aan de redenen voor non-respons en de uitval tijdens de follow-up periode. Tevens worden enkele sociaal-demografische en medische gegevens gepresenteerd van de patiënten die hebben deelgenomen aan het onderzoek (de responsgroep) en van de patiënten in de non-responsgroep. Vervolgens wordt de opbouw van de patiëntengroep in Maastricht behandeld (4.2). Over de non-respons van de Maastrichtse patiëntengroep is weinig informatie bekend (zie hoofdstuk drie). Wel is er informatie beschikbaar over de uitval binnen deze populatie. Tenslotte worden enkele kenmerken van de centrale verzorgers en andere zorgverleners beschreven alsmede de nonrespons of onvolledige beantwoording van de zorgverleners (4.3).

\subsection{Opbouw van de onderzoeksgroep in Noord-Limburg}

Zoals in hoofdstuk drie is beschreven, vond de selectie van patiënten in Noordlimburg plaats door de pathologen van het ziekenhuis in Venlo, in samenwerking met een huisarts uit de projectgroep. In de eerste fase van het onderzoek zijn in totaal 78 huisartsen aangeschreven over 245 patiënten die in de periode van december 1988 tot augustus 1989 geselecteerd waren door de pathologen.

Van al deze patiënten waren de diagnose, het geslacht en de leeftijd bekend. De geselecteerde patiëntengroep bestaat uit 136 mannen en 109 vrouwen. Hun gemiddelde leeftijd was 63 jaar (sd 12.4, range $27-89$ ). De diagnoses zijn in vier grote groepen verdeeld: mammacarcinomen $22 \%(n=54)$, longcarcinomen $25 \%$ ( $n$ $=61)$, maag-darmcarcinomen $24 \%(n=58 \%)$ en overigen $29 \%(n=72)$.

Bij de eerste meting in Noord-Limburg deden 79 patiënten mee aan het onderzoek. De overige patiënten behoren tot de non-respons-groepen. Om de redenen voor deze non-respons te achterhalen zijn de huisartsen opnieuw aangeschreven.

Aan deze huisartsen hebben we gevraagd wat volgens hen de reden voor non-respons was. Hierbij zijn drie categorieën onderscheiden: 
- Non-respons A: Patiënten voldeden niet aan de criteria. Zij waren bijvoorbeeld reeds overleden, te ziek, doof, psychisch niet in staat om interview te ondergaan.

- Non-respons B: Patiënten weigerden om mee te doen

- Non-respons C: Huisartsgebonden non-respons (weigering, te moeilijk om patiënt te vragen, geen tijd).

Tot categorie A behoorden 65 patiënten, 50 patiënten weigerden deelname en bij 51 patiënten was de non-respons huisartsgebonden. De eigenlijke non-respons, de 'weigeringen', moeten gecorrigeerd worden voor de twee andere vormen van nonrespons. Als Non-respons B $(n=50)$, de 'eigenlijke' non-respons, gecorrigeerd wordt voor non-respons $A$ en $C$, bedraagt deze $40 \%$.

Uiteindelijk bleven dus 79 patiënten over die deelnamen aan de eerste meting. In de follow-up periode van éen jaar vielen patiënten uit. Bij deze uitval kunnen twee categorieën worden onderscheiden:

- Uitval A: door ziekte of overlijden.

- Uitval B: door weigering van verdere medewerking.

In tabel 4.1 wordt de opbouw van de patiëntengroep weergegeven.

Tabel 4.1 Opbouw van patiëntengroep in Noord-Limburg ( $n=245$ ).

\begin{tabular}{lrl}
\hline & aantal & percentage \\
& 245 & $100 \%$ \\
Eerste selectie door patholoog & & \\
& 65 & $27 \%$ \\
1.Non-respons A:(niet onderzoekbaar) & 50 & $20 \%$ \\
2.Non-respons B:(weigering) & 51 & $21 \%$ \\
3.Non-respons C:(huisarts) & 79 & $32 \%$, gecorrigeerd $60 \%$ \\
Respons & 79 & $100 \%$ \\
Respons & 18 & $23 \%$ \\
4.Uitval A:(te ziek/overleden) & 10 & $13 \%$ \\
5.Uitval B:(weigering) & 51 & $64 \%$ \\
6.Volledig respons: & & \\
\end{tabular}

De totale uitval tijdens de meetperiode (één jaar) bedraagt 28 patiënten (36\%), waarvan 20 bij de tweede meting. Van deze 28 mensen waren er 18 overleden of te ziek en 10 patiënten weigerden verdere medewerking. De volledige-respons groep, dat wil zeggen de patiënten die tijdens elk van de drie metingen hebben meegedaan aan het onderzoek, bestaat uit 51 personen.

Er zijn nu dus zes groepen ontstaan: de non-responsgroepen A, B en C, uitvallers $A$ en $B$ en de volledige-responsgroep. Om na te gaan of er sprake is van selectiebias zijn deze groepen met elkaar vergeleken voor wat betreft sekse, leeftijd en diagnose. 
In tabel 4.2 wordt voor mannen en vrouwen de verdeling over de groepen weergegeven.

Tabel 4.2 Geslacht van geselecteerde patiënten: verdeling over de (non) responsgroepen $(n=245)$.

mannen vrouwen

$\begin{array}{lccc}\text { 1.Non-respons A } & (n=65) & 46 & 19 \\ \text { 2. Non-respons B } & (n=50) & 27 & 23 \\ \text { 3. Non-respons C } & (n=51) & 25 & 26 \\ \text { 4. Uitval A } & (n=18) & 12 & 6 \\ \text { 5. Uitval B } & (n=10) & 6 & 4 \\ \text { 6.Volledige respons } & (n=51) & 20 & 31 \\ & & \overline{136} & 109\end{array}$

Van de in totaal 136 geselecteerde mannen bleek $34 \%$ niet onderzoekbaar, $20 \%$ weigerde deelname en bij $18 \%$ was er sprake van huisartsgebonden non-respons. In totaal heeft $28 \%$ van de geselecteerde mannen meegedaan aan het onderzoek, $15 \%$ heeft deelgenomen aan alle drie de metingen. Bij de geselecteerde vrouwen zien we een ander beeld. Slechts $17 \%$ bleek niet onderzoekbaar, $21 \%$ weigerde en bij $24 \%$ was de non-respons huisartsgebonden. Van de geselecteerde vrouwen heeft $38 \%$ meegedaan aan het onderzoek, $28 \%$ bij alle drie de metingen.

In de volledige-responsgroep zien we een relatieve oververtegenwoordiging van vrouwen. Als de verdeling naar geslacht over de zes groepen bekeken wordt, kan worden geconcludeerd dat er significant meer mannen in de groep non-respons A zitten dan in de volledige-responsgroep. Ook in de groep uitvallers A, mensen die te ziek waren of waren overleden in de follow-up periode, bevinden zich relaticf meer mannen dan in de volledige-responsgroep $\left(\mathrm{chi}^{2}=13.5 ; \mathrm{p}<0.05\right)$.

De totale groep patiënten die aanvankelijk is geselecteerd bestaat uit meer mannen ( $n=136$ ) dan vrouwen $(n=109)$. Dit is te verklaren vanuit het feit dat de incidentiecijfers van kanker bij mannen bijna steeds hoger zijn dan bij vrouwen. Met name ten aanzien van longkanker is het verschil groot. $\mathrm{Bij}$ mannen is de incidentie van longkanker het hoogst, vooral in de leeftijdsgroep vanaf 60 jaar. Bij vrouwen heeft borstkanker het hoogste incidentiecijfer in alle leeftijdscategorieën.

In tegenstelling tot de incidentiecijfers zijn de prevalentiecijfers bij vrouwen in het algemeen hoger dan bij mannen. Dit houdt verband met de relatief gunstige levensverwachting van vrouwen (waardoor de kans op het krijgen van kanker toeneemt) en met het gegeven dat vrouwen vaker lijden aan vormen van kanker met betere overlevingskansen. $\mathrm{Bij}$ vrouwen is de prevalentie van borstkanker veruit het hoogst (629 patiënten per 100.000 van de vrouwelijke bevolking in 1980), bij mannen is de prevalentie van prostaat -en Iongkanker het hoogst, respectievelijk 142 en 134 patiënten per 100.000 (Stuurgroep toekomstscenario's gezondheidszorg, 1987). Deze verschillen in prevalentiecijfers kunnen de oververtegenwoordiging van 
vrouwen in de volledige-responsgroep en de relatieve oververtegenwoordiging van mannen in de non-responsgroep A en uitvallers A verklaren. Omdat de verdeling over de respons- c.q. non-responsgroepen en de verdeling naar de diagnoses voor mannen en vrouwen verschillend zijn, worden in tabel 4.3 gegevens over de leeftijd en diagnoses voor vrouwen en mannen apart weergegeven.

Tabel 4.3 (Non)responsgroepen, naar geslacht, leeftijd en diagnose $(n=245$ ).

\begin{tabular}{|c|c|c|c|c|c|c|c|}
\hline & $\begin{array}{l}\text { NR-A } \\
n=65\end{array}$ & $\begin{array}{l}\text { NR-B } \\
n=50\end{array}$ & $\begin{array}{l}\text { NR-C } \\
n=51\end{array}$ & $\begin{array}{l}\text { UitvA } \\
n=18\end{array}$ & $\begin{array}{l}\text { UitvB } \\
\mathrm{n}=10\end{array}$ & $\begin{array}{l}\text { VR } \\
n=51\end{array}$ & $\begin{array}{l}\text { totaal } \\
n=245\end{array}$ \\
\hline $\begin{array}{l}\text { Leeftijd (gem.) } \\
\text { mannen, vrouwen } \\
\text { samen }\end{array}$ & 68 & 60 & 62 & 64 & 66 & 61 & 63 \\
\hline Aantal mannen: & 46 & 27 & 25 & 12 & 6 & 20 & 136 \\
\hline Leeftijd (gem.) & 68 & 63 & 67 & 65 & 63 & 64 & 66 \\
\hline \multicolumn{8}{|l|}{ Diagnose: } \\
\hline Mamma & - & - & - & - & - & - & 0 \\
\hline Long & 21 & 11 & 9 & 6 & 2 & 5 & 54 \\
\hline Maag-darm & 11 & 2 & 6 & 5 & 1 & 7 & 32 \\
\hline Overige & 14 & 14 & 10 & 1 & 3 & 8 & 50 \\
\hline Aantal vrouwen: & 19 & 23 & 26 & 6 & 4 & 31 & 109 \\
\hline Leeftijd (gem.) & 68 & 56 & 57 & 62 & 69 & 60 & 60 \\
\hline \multicolumn{8}{|l|}{ Diagnose: } \\
\hline Mamma & 4 & 10 & 16 & 1 & 4 & 19 & 54 \\
\hline Long & 1 & 2 & 3 & - & - & 1 & 7 \\
\hline Maag-darm & 8 & 7 & 4 & 3 & - & 4 & 26 \\
\hline Overige & 6 & 4 & 3 & 2 & - & 7 & 22 \\
\hline
\end{tabular}

Met behulp van een één-weg variantieanalyse ( $F$-toets) zijn de verschillen in leeftijd getoetst. Bij de mannen zijn er wat de gemiddelde leeftijd betreft geen significante verschillen gevonden tussen de zes groepen. $\mathrm{Bij}$ de vrouwen is er een significant verschil tussen non-responsgroep $A$ en non-responsgroep $B$. De vrouwen die weigerden bij de eerste selectie, waren gemiddeld jonger dan de groep die niet onderzoekbaar was $(F=2.9 ; p<0.05)$. Als de mannen en vrouwen samen worden genomen, dan blijkt dat de gemiddelde leeftijd van de non-responsgroep A, (dus de groep patiënten die niet interviewbaar was), significant hoger te zijn dan die van nonresponsgroep $B$ en de volledige-responsgroep $(F=3.4 ; p<0.05)$. In de non responsgroep A bevonden zich veel mensen die al overleden waren. De significant hogere leeftijd binnen deze groep is verklaarbaar vanuit het feit dat de sterftecijfers van de meeste kankersoorten stijgen met het toenemen van de leeftijd, met name in de leeftijdscategorie 75 jaar en ouder (Van Ginneken en van der Vlist, 1985). 
Wat de verdeling naar diagnoses betreft zijn bij de mannen geen significante verschillen tussen de groepen gevonden. Vermeldenswaard is dat de groep mannen die niet onderzoekbaar was (non-responsgroep A) en de groep 'uitvallers door ziekte/ overlijden (uitval A) voor bijna de helft bestond uit longkanker-patiënten. Dit is te verklaren vanuit de ernst van de diagnose en de slechte overlevingsprognose bij veel van deze patiënten. Indien we kijken naar de sterftecijfers, dan kan geconcludeerd worden dat bij mannen de sterfte aan longkanker het hoogst is (Stuurgroep Toekomstscenario's Gezondheidszorg, 1987). Uit een rapport van de GGD NoordLimburg (1990) blijkt bovendien dat in Noord-Limburg (vergeleken met 39 andere regio's in Nederland) sprake is van een oversterfte voor longkanker bij mannen van $17 \%$.

Bij de vrouwen zien we wél significante verschillen in de verdeling van de diagnoses $\left(\mathrm{chi}^{2}=22.5 ; \mathrm{p}<0.10\right)$ : de volledige-responsgroep bevat relatief veel vrouwen met een mammacarcinoom.

Als we de diagnoses voor mannen en vrouwen samen nemen dan zien we dat $35 \%$ van alle geselecteerde patiënten met een mammacarcinoom, $19 \%$ van alle patiënten met een maag-darmcarcinoom, slechts $10 \%$ van de longkankerpatiënten en $21 \%$ van de patiënten met een andere diagnose, drie keer is geïnterviewd.

Het gaat in de volledige-responsgroep dus om relatief jonge patiënten, waarbij de vrouwen met een mammacarcinoom zijn oververtegenwoordigd.

Als de verdeling van de diagnoses in de volledige-responsgroep wordt vergeleken met de verdeling van de incidentie van kanker in de regio Noord-Limburg kunnen we concluderen dat in de volledige respons groep sprake is van een oververtegenwoordiging van borstkankerpatiënten. In de volledige-responsgroep gaat het om $61 \%$ van de vrouwen, terwijl, in 1987, borstkanker in deze regio $34 \%$ van alle geregistreerde vormen van kanker bij vrouwen inneemt (Progress report Dutch cancer registry, 1987).

De incidentie van kanker neemt toe naarmate mensen ouder worden. De patiënten in de volledige-responsgroep zijn echter relatief jong. Er is dus sprake van een zekere selectiebias naar leeftijd.

\subsection{Opbouw van de patiëntengroep in Maastricht}

Over de eerste selectie en de non-respons in Maastricht is weinig te zeggen omdat niet precies kon worden nagegaan hoe groot het non-responspercentage was van patiënten die door de specialisten benaderd waren voor het onderzoek. In deze regio zijn bij de eerste meting 38 onderzoekseenheden gevormd. Deze paliëntengroep bestaat uit 18 mannen en 20 vrouwen. Hun gemiddelde leeftijd was 58 jaar (sd 14.4, range 21 - 79). Tien patiënten hadden een mammacarcinoom, acht patiënten een longcarcinoom, twee patiënten een maag-darm carcinoom en 18 patiënten een andere vorm van kanker (zie tabel 4.4).

De totale uitval bij de tweede en derde meting was maar liefst $58 \%$; er bleven maar $16(42 \%)$ patiënten over. Tijdens de follow-up periode waren 18 patiënten (47\%) overleden of te ziek (volgens de patiënt zelf of volgens het oordeel van de specialist) om een interview te ondergaan. Vier patiënten $(11 \%)$ vielen buiten het onderzoek 
omdat ze niet meer wilden meewerken. In tabel 4.4 is de opbouw van de patiëntenpopulatie in Maastricht naar geslacht, leeftijd en diagnose weergegeven.

Tabel 4.4 (Non)responsgroepen naar geslacht leeftijd en diagnose, Maastricht (n $=16$ ).

\begin{tabular}{|c|c|c|c|c|}
\hline & $\begin{array}{l}\text { UitvalA } \\
n=18\end{array}$ & $\begin{array}{l}\text { UitvalB } \\
n=4\end{array}$ & $\begin{array}{l}\text { Volledig respons } \\
n=16\end{array}$ & $\begin{array}{l}\text { Totaal } \\
\mathrm{n}=38\end{array}$ \\
\hline $\begin{array}{l}\text { Leeftijd (gem) } \\
\text { mannen, vrouwen } \\
\text { samen }\end{array}$ & 64 & 58 & 53 & 58 \\
\hline Aantal mannen & 11 & 1 & 6 & 18 \\
\hline Leeftijd (gem.) & 66 & 66 & 46 & 59 \\
\hline \multicolumn{5}{|l|}{ Diagnose: } \\
\hline Mamma & 1 & - & - & 1 \\
\hline Long & 3 & 1 & 1 & 5 \\
\hline Maag-darm & 2 & - & - & 2 \\
\hline Overigen & 5 & - & 5 & 10 \\
\hline Aantal vrouwen & 7 & 3 & 10 & 20 \\
\hline Leeftijd (gem.) & 58 & 56 & 57 & 57 \\
\hline \multicolumn{5}{|l|}{ Diagnose: } \\
\hline Mamma & 4 & - & 5 & 9 \\
\hline Long & 1 & - & 2 & 3 \\
\hline Maag-Darm & - & - & - & - \\
\hline Overigen & 2 & 3 & 3 & 8 \\
\hline
\end{tabular}

Er zijn geen significante leeftijdsverschillen gevonden tussen de responsgroepen. Net als in Noord-Limburg zien we dat de mannen relatief zijn oververtegenwoordigd in de groep uitvallers $\mathrm{A}$ en vrouwen in de volledige-responsgroep. De verdeling naar geslacht en diagnose over de drie groepen verschilt niet significant. We zien echter wel dezelfde tendens als in Noord-Limburg. De volledige-responsgroep bevat meer vrouwen dan mannen en de gemiddelde leeftijd van mannen in de volledige-respons groep is lager dan in de groepen uitvallers.

\subsection{Sociaal-demografische en ziektekenmerken van patiënten}

In totaal hebben 117 patiënten deelgenomen aan de eerste meting van het onderzoek, 79 in Noord-Limburg en 38 in Maastricht en omstreken. De patiënten die hebben meegedaan aan het onderzoek, worden verdeeld in uitvallers A, uitvallers B en de volledige-respons groep (vr). In tabel 4.5. worden enkele sociaal-demografische en medische gegevens van deze respons-groepen beschreven. De volgende variabelen zijn in de tabel opgenomen: leeftijd, geslacht, burgerlijke staat (samenwonend met partner of niet), sociaal-economische status (ses), diagnose, overlevingsprognose, 
stadium van de ziekte (metastase of niet) en de behandeling (operatie versus andere methoden zoals chemotherapie of bestraling al dan niet in combinatie).

Tabel 4.5 Sociaal-demografische en ziektekenmerken, responsgroepen Nrd-Limburg en Maastricht $(n=67)$.

\begin{tabular}{|c|c|c|c|c|c|c|}
\hline & \multicolumn{3}{|c|}{ Noord-Limburg } & \multicolumn{3}{|c|}{ Maastricht } \\
\hline & $\begin{array}{l}\text { UitvalA } \\
n=18\end{array}$ & $\begin{array}{l}\text { UitvalB } \\
n=10\end{array}$ & $\begin{array}{l}3 \mathrm{VR} \\
n=51\end{array}$ & $\begin{array}{l}\text { Uitval/ } \\
\mathrm{n}=18\end{array}$ & $\begin{array}{l}\text { A UitvalB } \\
n=4\end{array}$ & $\begin{array}{l}B \quad V R \\
n=16\end{array}$ \\
\hline Leeftijd (gem.) & 64 & 66 & 61 & 63 & 59 & 53 \\
\hline Ses & .00 & -.42 & -.33 & .73 & -.90 & .76 \\
\hline $\begin{array}{l}\text { Geslacht } \\
\% \text { Mannen }\end{array}$ & $67 \%$ & $60 \%$ & $39 \%$ & $61 \%$ & $25 \%$ & $38 \%$ \\
\hline Partner & $83 \%$ & $70 \%$ & $73 \%$ & $78 \%$ & $75 \%$ & $56 \%$ \\
\hline $\begin{array}{l}\text { Diagnose: } \\
\text { Mamma }\end{array}$ & 1 & 4 & 19 & 5 & - & 5 \\
\hline Long & 6 & 2 & 6 & 4 & 1 & 3 \\
\hline Maagdarm & 8 & 1 & 11 & 2 & - & - \\
\hline M.Lymphoom & 1 & 1 & 1 & 2 & 3 & 6 \\
\hline Urogenitaal & 1 & 2 & 7 & 1 & - & 1 \\
\hline Gynaecologisch & 1 & - & 5 & 1 & - & - \\
\hline overig & - & - & 2 & 3 & - & 1 \\
\hline $\begin{array}{l}\text { Behandeling: } \\
\text { alleen operatie }\end{array}$ & 8 & 4 & 28 & 2 & 1 & 3 \\
\hline Metastasen: & 12 & 4 & 12 & 14 & 0 & 10 \\
\hline Prognose (gem) & 3.5 & 2.9 & 2.3 & 3.6 & 2.2 & 2.6 \\
\hline Ziekteduur mnd. & 4.4 & 3.7 & 3.5 & 26 & 28 & 41 \\
\hline
\end{tabular}

In Noord-Limburg zijn er tussen de responsgroepen geen significante verschillen wat leeftijd, burgerlijke staat, opleidingsnivo, de behandeling en de ziekteduur betreft. Eerder noemden we al de meerderheid van vrouwen met een mammacarcinoom in de volledige-responsgroep. Zoals bovendien te verwachten is, is de volledigeresponsgroep gemiddeld minder ernstig ziek dan de uitvallersgroep A, de volledige responsgroep heeft gemiddeld een betere overlevingsprognose dan de uitvallers A ( $F$ $=13 ; p<0.05)$. De volledige-responsgroep bevat bovendien minder patiënten met metastasen dan de uitvallers $\mathrm{A}\left(\mathrm{chi}^{2}=10.2 ; \mathrm{p}<0.05\right)$.

Ook bij de Maastrichtse populatie vinden we significante verschillen tussen de volledige- responsgroep en de uitvallers $A$ wat betreft de gemiddelde overlevingsprognose $(F=6.3 ; p<0.05)$ en het stadium van de ziekte $\left(\mathrm{chi}^{2}=6.9 ; \mathrm{p}<0.05\right)$. In 
de volledige responsgroep hebben relatief weinig mensen metastasen en heeft men gemiddeld een betere overlevingsprognose.

De volledige-responsgroepen in Noord-Limburg en Maastricht werden met elkaar vergeleken. Doordat de selectie van patiënten in Maastricht anders is verlopen dan in Noord-Limburg, zien de populaties er verschillend uit. Op de eerste plaats valt op dat de Maastrichtse groep gemiddeld een hogere sociaal-economische status heeft $(t=1.7 ; p<0.10)$ en jonger is dan de populatie in Noord-Limburg $(t=-2.1 ; p$ $<0.05)$. De patiënten in Maastricht zijn gemiddeld veel langer ziek dan de patiënten in Noord-Limburg $(t=6.7 ; p<0.05)$. Bovendien bevat de Maastrichtse groep meer patiënten met metastasen $\left(\mathrm{chi}^{2}=6.2 ; \mathrm{p}<0.05\right)$ en relatief veel mensen die naast een operatieve behandeling chemotherapie en/of bestraling kregen $\left(\mathrm{chi}^{2}=\right.$ $5 ; \mathrm{p}<0.05$ ). Ook de verschillende diagnosegroepen zijn niet gelijk vertegenwoordigd. Dit is verklaarbaar vanuit het gegeven dat in Maastricht de meeste patiënten zijn geselecteerd door de internist-oncologen, terwijl in Noord-limburg ook 'chirurgische' patiënten in de selectie zijn opgenomen. Het is waarschijnlijk dat internist-oncologen vaker te maken krijgen met bepaalde diagnosegroepen zoals nonHodgkin en Hodgkin lymphomen dan chirurgen en bovendien vaker patiënten behandelen in een vergevorderd stadium van de ziekte. Het verschil in behandeling tussen de beide groepen hangt daar waarschijnlijk mee samen.

Door deze verschillen tussen de volledige-responsgroepen in Noord-Limburg en Maastricht zijn de groepen niet zomaar samen te voegen in de verdere analyses. De verschillen in de hierboven genoemde onafhankelijke variabelen zullen zeer waarschijnlijk consequenties hebben voor de scores op de afhankelijke variabele 'kwaliteit van leven'. In hoofdstuk vijf wordt hier nader op ingegaan.

\subsection{Zorgverleners}

Behalve de patiënten zijn ook hun centrale verzorgers en professionele zorgverleners in dit onderzoek betrokken. Deze zorgverleners zijn geïnterviewd. De professionele zorgverleners hebben ook nog vragenlijsten ingevuld. Van deze zorgverleners worden de belangrijkste gegevens gepresenteerd.

\subsubsection{De centrale verzorgers}

Met centrale verzorgers worden de informele helpers bedoeld op wie het grootste deel van de zorg neerkomt. De patiënt zelf gaf aan wie voor hem/haar de centrale verzorger was. In Noord-Limburg zijn 65 centrale verzorgers geïnterviewd, in Maastricht 26. Het ging in bijna drie kwart van de gevallen (71\%) om vrouwen. De grootste groepen werden gevormd door de partners $(58 \%)$ en door kinderen van patiënten $(22 \%)$.

De gemiddelde leeftijd van de partners van patiënten bedroeg 58 jaar (sd 10.8 range 28 - 79), van de kinderen was de gemiddelde leeftijd 34 jaar (sd 7.7 range 23 - 46). In tabel 4.6. wordt de aard van de relatie van de centrale verzorger tot de patiënt weergegeven. Hierbij is een onderscheid gemaakt tussen mannelijke c.q. vrouwelijke patiënten, tussen mannelijke c.q. vrouwelijke centrale verzorgers en tussen patiënten 
die al dan niet samenwonen met een partner. Relatief gezien komt de zorg vaak neer op de vrouwelijke partner of een dochter. Van alle gehuwde vrouwen noemt $67 \%$ de echtgenoot als centrale verzorger en $83 \%$ van de gehuwde mannelijke patiënten noemt de vrouwelijke partner als centrale verzorger. Bij alleenstaanden treedt in $43 \%$ van de gevallen één van de kinderen, met name de dochter, op als centrale verzorger; in $24 \%$ van de gevallen een vriend of vriendin.

Tabel 4.6 Centrale verzorgers van samenwonende en alleenstaande patiënten; verdeling naar geslacht en relatie tot de patiënt $(n=91)$.

Patiënt woont (gehuwd) Patiënt

samen met partner alleenstaand

Patiënt $q$ Patiènt $\delta$ Patiënt $q$ Patiënt $\delta$ totaal

$\begin{array}{lllll}\text { cv } \delta \quad 20 \text { partner } & 1 \text { vriend } & 1 \text { zoon } & 1 \text { zoon } & 26 \\ & 1 \text { zoon } & 1 \text { neef } & & \\ & 1 \text { vriend } & \end{array}$

$\begin{array}{llll}\text { cv } 9 \quad 4 \text { dochter } & 33 \text { partner } & 5 \text { dochter } & 2 \text { dochter } \\ 3 \text { vriendin } & 6 \text { dochter } & 2 \text { zus } & 1 \text { zus } \\ 1 \text { nicht } & & 3 \text { vriendin } & 1 \text { vriendin } \\ 1 \text { buurvrouw } & & 1 \text { nicht } & 1 \text { moeder } \\ & & 1 \text { buurvrouw }\end{array}$

65

totaal 30

40

15

6

91

\subsubsection{De professionele zorgverleners}

In Noord-Limburg hebben tijdens de eerste meting 43 verschillende huisartsen deelgenomen aan het onderzoek. Dat betekent dat enkele huisartsen over meer dan én patiënt vragenlijsten hebben ingevuld.

Bij de eerste meting hebben 15 verschillende specialisten, werkzaam in het Venlose ziekenhuis, onze vragen beantwoord. Het ging om drie internisten, drie longartsen, vijf chirurgen, twee urologen, één gynaecoloog en én k.n.o-arts.

De verpleegkundigen vormen in dit onderzoek de kleinste groep zorgverleners. In Noord-Limburg zijn 18 wijkverpleegkundigen en én wijkziekenverzorgende geïnterviewd. In Noord-Limburg deden geen ziekenhuisverpleegkundigen mee. 
In Maastricht zijn 23 verschillende huisartsen bij het onderzoek betrokken. Daarnaast zes internisten, één longarts en één k.n.o-arts, allen werkzaam in het Academisch Ziekenhuis Maastricht. In totaal zijn hier zes verpleegkundigen geïnterviewd. Drie verpleegkundigen waren werkzaam op het dagcentrum waar patiënten chemotherapie kregen. De andere verpleegkundigen waren werkzaam op een oncologische verpleegafdeling.

\subsubsection{Onvolledige beantwoording door de zorgverleners}

Het was de bedoeling om bij de deelnemende patiënten alle genoemde zorgverleners te interviewen of deze een vragenlijst te laten invullen. Als de casus niet volledig is spreken we van onvolledige beantwoording. De respons van de betrokken zorgverleners bij de drie metingen is in tabel 4.7 weergegeven

Tabel 4.7 Respons zorgverleners op de drie meetmomenten in Noord-Limburg en Maastricht ( $\mathrm{n}=117)$.

t1

t2

t3

Noord-Limburg

aantal patiënten

79

59

51

Centrale verzorgers

$65(82 \%)$

$46(78 \%) \quad 42(82 \%)$

Huisartsen

$74(94 \%)$

$52(88 \%) \quad 45(88 \%)$

Specialisten

$52(66 \%)$

$17(29 \%)$

Wijkverpleegkundigen

$19(28 \%)$

$4(7 \%)$

Maastricht

aantal patiënten

38

20

16

Centrale verzorgers

$26(68 \%)$

$25(66 \%)$

Huisartsen

$31(82 \%)$

Specialisten

$6(16 \%)$

$\begin{array}{ll}13(65 \%) & 10(63 \%) \\ 13(65 \%) & 6(38 \%) \\ 16(80 \%) & - \\ - & -\end{array}$

De medewerking van de centrale verzorgers en huisartsen bleef in Noord-Limburg ook bij de tweede en derde meting in het algemeen goed. De medewerking van de specialisten daalde echter aanmerkelijk bij de tweede meting. Bij de wijkverpleegkundigen deed zich het probleem voor dat, bij latere metingen, maar weinig patiënten contact hadden met een wijkverpleegkundige. Bij de derde meting zijn daarom geen vragenlijsten meer voorgelegd aan de specialisten en de wijkverpleegkundigen. In Maastricht was de respons van de huisartsen en centrale verzorgers matig en in ieder geval minder dan in Noord-Limburg. De respons van de specialisten was in Maastricht daarentegen hoog.

Bij de eerste meting is nagegaan, wat de redenen zijn voor de non-respons van de zorgverleners: 
- Centrale verzorgers

In Noord-Limburg beschikken we bij 14 onderzoekseenheden niet over gegevens van de centrale verzorger. Vijf patiënten hadden liever niet dat de centrale verzorger geïnterviewd werd. Drie centrale verzorgers konden dat volgens de patiënt zelf psychisch niet aan. Twee keer was er geen centrale verzorger. Eén centrale verzorger woonde in het buitenland. Een keer is van het interviewen van een partner afgezien omdat de patiēnte inmiddels was overleden. In twee gevallen woonde de centrale verzorger het interview met de patiënt bij en vonden zij het niet nodig nog eens apart geïnterviewd te worden.

In Maastricht gaat het om de non-respons van 12 centrale verzorgers. Zeven patiënten wilden niet dat er een centrale verzorger geïnterviewd werd. Drie patiënten in deze regio waren reeds overleden voor de centrale verzorger geïnterviewd kon worden, twee patiënten hadden geen centrale verzorger.

- Huisartsen

Bij vijf patiënten in Noord-Limburg heeft de huisarts de vragenlijst niet teruggestuurd. De redenen hiervoor zijn niet bekend.

In Maastricht waren drie patiënten reeds overleden voordat de huisarts geïnterviewd kon worden. Eén patiënte had geen huisarts, eén patiënt wilde niet dat we contact opnamen met de huisarts. Bij negen patiënten heeft de huisarts medewerking geweigerd. Bij 14 eenheden was er dus sprake van non-respons van de huisarts.

- Specialisten

De onvolledige beantwoording door specialisten in Noord-limburg (in totaal 27) kan voor een deel verklaard worden vanuit het feit dat veel specialisten vragenlijsten moesten invullen over meer dan één patiënt. Drie specialisten lieten schriftelijk weten niet (meer) mee te willen doen aan het onderzoek om deze reden en omdat ze de zin van het onderzoek niet inzagen. Twaalf patiënten $(15 \%)$ waren onder behandeling bij een van deze drie specialisten. De overige specialisten stuurden de vragenlijsten niet terug, ook niet na het versturen van een herinnering.

In Maastricht stuurden de specialisten bij zeven onderzoekseenheden de vragenlijst niet terug.

- Verpleegkundigen

Bij 60 van de 79 patiënten in Noord-Limburg was geen wijkverpleegkundige betrokken bij het zorgproces.

In Maastricht had bij 32 patiënten de ziekenhuisopname vaak al geruime tijd geleden plaatsgevonden, zodat het niet zinvol was om een ziekenhuisverpleegkundige te interviewen.

Voor de volledige- responsgroep is nagegaan hoeveel complete onderzoekseenheden gevormd zijn in de drie metingen. Het gaat om het aantal casus waarbij zowel de huisarts, de centrale verzorger als de specialist deelnamen aan het onderzoek. Besloten werd dat resultaten met betrekking tot de (wijk) verpleegkundigen, gezien het geringe aantal, in dit verslag buiten beschouwing worden gelaten.

Tabel 4.8 geeft de respons weer van de betrokken zorgverleners en het aantal complete onderzoekseenheden bij de volledige-responsgroepen in beide regio's.

De respons van de centrale verzorgers en huisartsen bij de volledige responsgroep in Noord-Limburg is gedurende de meetperiode stabiel gebleven en is goed te noemen. De non-respons van de specialisten was echter aanzienlijk en ook de 
voornaamste oorzaak van het geringe aantal complete onderzoekseenheden. In Maastricht is de respons van de centrale verzorgers bij de volledige responsgroep acceptabel en stabiel. De respons van de huisartsen is gedurende de meetperiode afgenomen. De respons van de specialisten is in Maastricht hoog.

Tabel 4.8 Respons zorgverleners bij de volledige-responsgroepen Noord-Limburg en Maastricht $(n=67)$.

\begin{tabular}{llll}
\hline & $t 1$ & $t 2$ & $t 3$ \\
\hline Noord-Limburg $(\mathrm{n}=51)$ & & & \\
& & & \\
centrale verzorger & $43(84 \%)$ & $42(82 \%)$ & $42(82 \%)$ \\
huisarts & $48(94 \%)$ & $48(94 \%)$ & $45(88 \%)$ \\
specialist & $34(67 \%)$ & $17(33 \%)$ & - \\
complete eenheden & $27($ ha-cv-sp) & 13 (ha-cv-sp) & 39 (ha-cv) \\
& & 40 (ha-cv) & \\
Maastricht $(n=16)$ & & & $10(63 \%)$ \\
centrale verzorger & $11(69 \%)$ & $10(63 \%)$ & $7(44 \%)$ \\
huisarts & $12(75 \%)$ & $10(63 \%)$ & - \\
specialist & $15(94 \%)$ & $14(88 \%)$ & 5 (ha-cv) \\
complete eenheden & $8($ ha-cv-sp) & 5 (ha-cv-sp) \\
& & 7 (ha-cv) & \\
& & & \\
\hline
\end{tabular}

In Noord-Limburg zijn 23 eenheden compleet, in Maastricht vier. Van al deze gevallen hebben we de eerste meting van de specialist, drie metingen van de huisarts en drie metingen van de centrale verzorger.

Dit betekent dat we te maken hebben met ontbrekende gegevens, hetgeen uiteraard consequenties heeft voor de analyses.

\subsection{Samenvatting en conclusies}

In dit hoofdstuk is de selectie van de onderzoekseenheden beschreven. Op de eerste plaats is ingegaan op de selectie van de patiënten in Noord-Limburg. Hier werden in eerste instantie 245 patiënten geselecteerd door de pathologen van het ziekenhuis in Venlo. De gecorrigeerde respons bedroeg $60 \%$. Negenenzeventig patiënten hebben meegedaan aan de eerste meting. Tijdens de follow-up periode zijn we geconfronteerd met uitval (38\%) door overlijden en weigering. Dit is een bekend probleem dat zich voordoet in longitudinaal onderzoek, zeker bij deze patiënten. Het probleem wordt hier echter nog versterkt door de noodzaak om voor een deel van de onderzoeksvragen verschillende respondenten per casus te betrekken. Uiteindelijk houden we een volledige-responsgroep over van 51 patiënten. Het betreft voor het merendeel zogenaamde 'healthy patients', betrekkelijk jonge patiënten met een relatief goede overlevingsprognose en er zijn relatief weinig patiënten die metastasen hebben. De groep bestaat voor een groot deel uit vrouwen met een mammacarcinoom. De positieve selectie van patiënten in deze volledige-responsgroepen kan consequenties hebben voor de analyses van de gegevens en de resultaten van het 
onderzoek. De resultaten van ons onderzoek zijn daarom niet te generaliseren naar alle kankerpatiënten.

In Maastricht zijn we tijdens de eerste meting begonnen met 38 patiënten. De uitval bedroeg hier maar liefst $58 \%$. Een volledige-responsgroep van 16 patiënten bleef over. Ook hier gaat het om patiënten met een relatief goede overlevingsprognose en met een gunstig stadium van de ziekte.

De Maastrichtse volledige-responsgroep verschilt op een aantal aspecten van de Noord-Limburgse groep. Respondenten in Maastricht zijn gemiddeld jonger en hebben een hogere sociaal-economische status dan die in Noord-Limburg. Bovendien is de verdeling over de diagnosegroepen in Maastricht anders dan in NoordLimburg. Respondenten in Maastricht zijn gemiddeld veel langer ziek, hebben veelal metastasen en hebben niet alleen een operatie maar ook andere behandelingsvormen ondergaan. De verschillen tussen de patiënten in Noord-Limburg en Mastricht zullen in het volgende hoofdstuk een aandachtspunt vormen.

De analyses waarvan de resultaten in de volgende hoofdstukken worden weergegeven hebben, omdat het naast transversale analyses ook om longitudinale analyses gaat, alleen betrekking op de volledige-responsgroepen in beide lokaties.

De onderzoekseenheden bestaan niet alleen uit patiënten maar ook uit zorgverleners. Bij 91 patiënten (65 in Noord-Limburg, 26 in Maastricht) is een centrale verzorger geïnterviewd. Het merendeel van deze centrale verzorgers bestaat uit vrouwen. Het gaat vaak om de partner van de patiënt en dochters. De respons van de centrale verzorgers is in het algemeen acceptabel.

Verder zijn in het onderzoek 66 huisartsen, 21 specialisten, 19 wijkverpleegkundigen en zes ziekenhuisverpleegkundigen betrokken. De respons van de huisartsen is in Noord-Limburg hoog, variërend van 88 tot $94 \%$. In Maastricht is de respons van de huisartsen bij de eerste en tweede meting acceptabel (65\%) maar in de derde meting laag $(38 \%)$. Bij de specialisten zien we het omgekeerde. In Noord-Limburg is de respons in de eerste meting acceptabel (66\%) maar in de tweede meting laag (29\%); in Maastricht is de respons bij de specialisten hoog (80-88\%). Bij de eerste meting, zijn in Noord-Limburg 19 (28\%) wijkverpleegkundigen betrokken. Bij de tweede meting daalde dit aantal zo drastisch dat besloten werd de wijkverpleegkundigen niet meer voor een derde meting te benaderen. In Maastricht werden zes verpleegkundigen éen keer geïnterviewd. In Noord-Limburg zijn bij de volledige-responsgrœep 23 onderzoekseenheden compleet, in Maastricht vier. Compleet wil zeggen dat we drie keer de gegevens hebben van de patiënt, de huisarts en de centrale verzorger en minstens de eerste meting van de specialist. 



\section{Kwaliteit van leven en het beloop daarvan}

In dit hoofdstuk wordt de kwaliteit van het leven van de patiënten en de veranderingen daarin op groepsniveau beschreven. Tevens komen de veranderingen op individueel niveau aan de orde. Bij de analyses beperken we ons tot de patiënten in de volledige-responsgroepen van Noord-Limburg $(n=51)$ en Maastricht $(n=16)$.

\subsection{Gemiddelde waarden op de maten voor kwaliteit van leven}

Om de veranderingen in de kwaliteit van het leven op groepsniveau te bestuderen zijn de gemiddelde waarden van de scores op lichamelijke en psychische klachten, de globale maat voor onwelbevinden en de Sickness Impact Profile (SIP) op de drie meetmomenten weergegeven. Per variabele is een multivariate variantieanalyse voor herhaalde metingen uitgevoerd om na te gaan of de waarden van de variabelen op de drie meetmomenten van elkaar afwijken. De scores van de patiënten in NoordLimburg en Maastricht zijn in deze analyses samengenomen, waarbij steeds nagegaan is of er een tijdseffect, een groepseffect en een interactie-effect bestaat. Een tijdseffect wil zeggen dat er een significante verandering in de tijd plaatsvindt. Een groepseffect betekent in dit kader dat er significante verschillen bestaan tussen de scores van patiënten uit Noord-Limburg en patiënten uit Maastricht. Een interactie-effect treedt op als de verandering in de tijd zich meer voordoet bij de ene dan bij de andere groep (Noord-Limburg of Maastricht).

\subsubsection{Disfunctioneren}

In tabel 5.1, waarin de gemiddelde scores op de SIP worden weergegeven, is te zien dat zowel de patiënten in Noord-Limburg als de patiënten in Maastricht gemiddeld beter gaan functioneren in de loop van de meetperiode. De totaalscores op de Sickness Impact Profile worden significant lager in de loop der tijd $(F=9.9(2,64)$; $\mathrm{p}<0.05)$. 


\begin{tabular}{|c|c|c|c|}
\hline \multicolumn{4}{|l|}{ Totaal scores * } \\
\hline Noord-Limburg $(n=51)$ & 9.1 & 6.9 & 5.8 \\
\hline Maastricht $(n=16)$ & 13.6 & 11.2 & 9.0 \\
\hline Totaal $(n=67)$ & 10.1 & 7.9 & 6.6 \\
\hline \multicolumn{4}{|l|}{ Slapen/rusten * } \\
\hline Groep Noord-Limburg & 13.3 & 9.5 & 8.2 \\
\hline Groep Maastricht & 19.3 & 12.7 & 9.3 \\
\hline Totale groep & 14.7 & 10.2 & 8.4 \\
\hline \multicolumn{4}{|l|}{ Emotioneel gedrag * ++ } \\
\hline Groep Noord-Limburg & 5.7 & 5.4 & 5.7 \\
\hline Groep Maastricht & 14.1 & 7.2 & 8.0 \\
\hline Totale groep & 7.7 & 5.8 & 6.2 \\
\hline \multicolumn{4}{|l|}{ Lichaamsverzorging } \\
\hline Groep Noord-Limburg & 5.6 & 5.0 & 4.2 \\
\hline Groep Maastricht & 9.8 & 8.6 & 8.7 \\
\hline Totale groep & 6.6 & 5.9 & 5.2 \\
\hline \multicolumn{4}{|c|}{ Huishoudelijke activiteiten * } \\
\hline Groep Noord-Limburg & 23.0 & 16.7 & 12.6 \\
\hline Groep Maastricht & 28.1 & 21.0 & 20.4 \\
\hline Totale groep & 24.2 & 17.7 & 14.4 \\
\hline \multicolumn{4}{|l|}{ Mobiliteit * } \\
\hline Groep Noord-Limburg & 11.4 & 5.7 & 4.9 \\
\hline Groep Maastricht & 15.4 & 12.0 & 7.1 \\
\hline Totale groep & 12.3 & 7.1 & 5.4 \\
\hline \multicolumn{4}{|l|}{ Sociale interactie ** } \\
\hline Groep Noord-Limburg & 10.5 & 6.0 & 5.0 \\
\hline Groep Maastricht & 15.7 & 15.0 & 11.3 \\
\hline Totale groep & 11.7 & 8.3 & 6.5 \\
\hline \multicolumn{4}{|l|}{ Lopen $\cdots$} \\
\hline Groep Noord-Limburg & 7.2 & 5.9 & 7.1 \\
\hline Groep Maastricht & 18.2 & 18.0 & " $\quad 16.2$ \\
\hline Totale groep & 9.8 & 8.8 & 9.2 \\
\hline \multicolumn{4}{|l|}{ Alertheid } \\
\hline Groep Noord-Limburg & 7.7 & 7.9 & 8.1 \\
\hline Groep Maastricht & 10.7 & 4.6 & 3.5 \\
\hline Totale groep & 8.4 & 7.1 & 7.1 \\
\hline \multicolumn{4}{|l|}{ Communicatie } \\
\hline Groep Noord-Limburg & 2.9 & 2.6 & 2.4 \\
\hline Groep Maastricht & 2.2 & 1.5 & 1.5 \\
\hline Totale groep & 2.8 & 2.4 & 2.3 \\
\hline \multicolumn{4}{|l|}{ Recreatie } \\
\hline Groep Noord-Limburg & 23.0 & 17.0 & 15.9 \\
\hline Groep Maastricht & 29.8 & 24.3 & 13.8 \\
\hline Totale groep & 24.6 & 18.7 & 15.4 \\
\hline \multicolumn{4}{|l|}{ Eten } \\
\hline Groep Noord-Limburg & 5.6 & 3.0 & 2.6 \\
\hline Groep Maastricht & 2.0 & 3.5 & 1.8 \\
\hline Totale groep & 4.8 & 3.1 & 2.4 \\
\hline
\end{tabular}


Tijdseffecten worden met name gevonden bij de categorieën 'slapen' ( $F=5.6$ (2,64); $\mathrm{p}<0.05)$, 'huishoudelijke activiteiten' $(\mathrm{F}=5.5,(2,64) ; \mathrm{p}<0.05)$, 'emotioneel gedrag' $(F=2.8,(2,64) ; p<0.05)$,'mobiliteit' $(F=5.7,(2,64)$; $p$ $<0.05)$ en 'recreatie' $(F=6.3,(2,64)$; $p<0.05)$. Groepseffecten worden gevonden voor de categorieën 'lopen' en 'sociale interactie' $(p<0.05)$; patiënten in Maastricht en omgeving functioneren wat deze aspecten betreft slechter dan de patiënten in Noord-Limburg. Een interactie-effect wordt alleen gevonden voor de categorie 'emotioneel gedrag'. De verandering in de tijd in deze categorie treedt met name op in Maastricht $(\mathrm{F}=3.1 ; \mathrm{p}<0.05)$.

Uit tabel 5.1 blijkt dat op de categorieën huishoudelijke activiteiten, recreatie en vrije tijd, slapen en mobiliteit het hoogst gescoord wordt. Bij deze aspecten van het functioneren treden blijkbaar de meeste problemen op.

Om het aantal variabelen te reduceren wordt in verdere analyses alleen met de totaalscore van de SIP gewerkt. De totaalscores op de SIP van de patiënten in ons onderzoek zijn vergelijkbaar met de gemiddelde totaalscores van andere patiëntencategorieën zoals patiënten met reuma (gem 14.6), spierziekten (gem 11.4), nierdialyse (gem 10.3), de ziekte van Bechterew (gem 8.9) en de ziekte van Crohn (gem 5.6) (De Witte, 1989; Terpstra, 1990; Janssen 1992).

\subsubsection{Onwelbevinden}

In tabel 5.2 worden de gemiddelde waarden en de standaarddeviaties op de drie meetmomenten weergegeven voor lichamelijke klachten, psychische klachten en globaal onwelbevinden.

Tabel 5.2 Vergelijking scores op 'onwelbevinden' op drie meetmomenten $(n=67)$ \#.

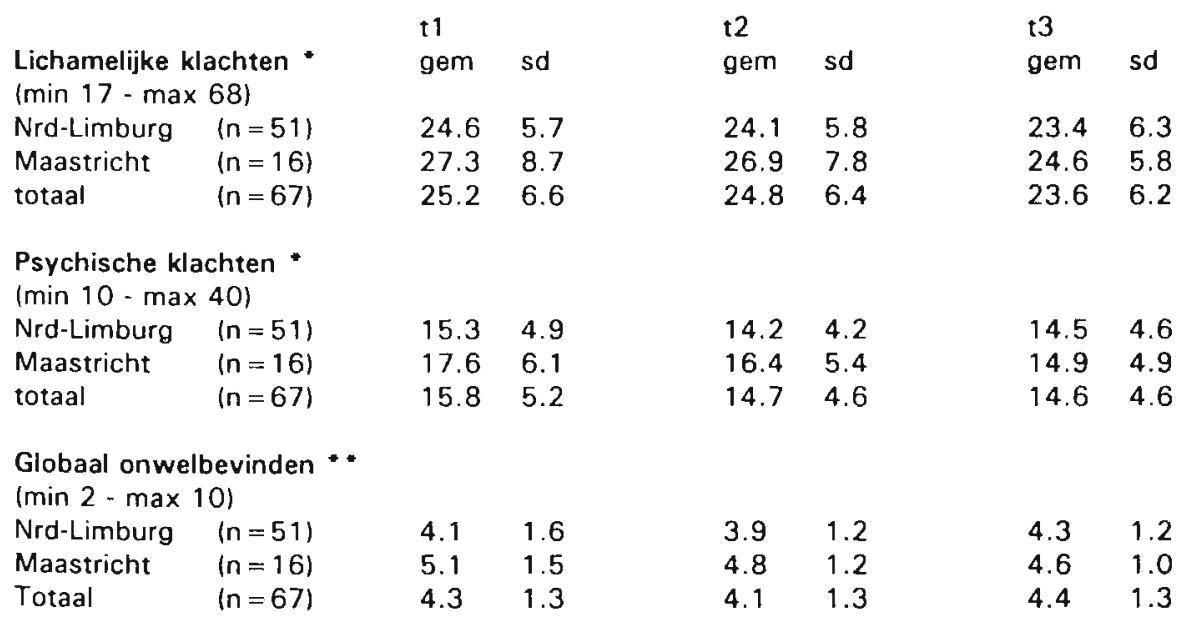

\# Een lagere score betekent minder van het betreffende kenmerk of een beter welbevinden.

* = tijdseffect, * $*$ groepseffect. 
Zoals uit tabel 5.2 blijkt rapporteert de totale patiëntengroep gemiddeld minder lichamelijke klachten na verloop van tijd. Er is sprake van een significant tijdseffect $(\mathrm{F}=3.4(2,64) ; \mathrm{p}<0.05)$. Bij de eerste meting scoren de patiënten hoger op klachten dan bij de tweede en derde meting. Het gaat hierbij om een lineair verloop. Ook ten aanzien van psychische klachten treedt een tijdseffect op. De psychische klachten verminderen na verloop van tijd $(F=5.0(2,64)$; $p<0.05)$. Opvallend is dat de daling van de klachtenscores zich sterker voordoet in Maastricht dan in Noord-Limburg. Over de aard van de klachten kan worden opgemerkt dat bij de drie metingen systematisch hoog gescoord wordt op de items: 'moeheid', 'pijnlijke spieren', 'zenuwachtigheid', 'slapeloosheid' en 'gespannen zijn'. De scores op de lichamelijke en psychische klachten zijn vergelijkbaar met die van de patiënten in het onderzoek van de Haes (1988). In haar onderzoek scoren patiënten die recent zijn geopereerd of chemotherapie hebben gehad gemiddeld 27.9 op de lijst voor lichamelijke klachten en 16.6 op de lijst van psychische klachten. Kankerpatiënten die drie jaar of langer ziektevrij zijn scoren gemiddeld 24.6 respectievelijk 16.1. Gezonde mensen scoren gemiddeld 21.7 op lichamelijke klachten en 14.8 op de psychische dimensie.

Op de maat voor het globale onwelbevinden scoren respondenten gemiddeld laag; mensen blijken gemiddeld tevreden te zijn en zich goed te voelen. Dit verandert niet significant in de tijd. Wel is er sprake van een groepseffect; patiënten uit de Maastrichtse groep scoren gemiddeld hoger op globaal onwelbevinden dan de patiënten uit Noord-Limburg $(F=8.3 ; p<0.05)$. De algemene positieve evaluatie van het globale welbevinden is niet uitzonderlijk. Ook in vergelijkbare onderzoeken naar kwaliteit van leven worden, ondanks dat het functioneren door ziekte en behandeling is aangetast, positieve evaluaties met betrekking tot kwaliteit van leven gerapporteerd (De Haes, 1988; De Witte, 1989).

\subsubsection{Illustratieve passages uit de interviews}

Tijdens de interviews zijn ook enkele open vragen gesteld met betrekking tot veranderingen in de kwaliteit van leven. Hierbij zijn drie thema's aan bod gekomen: 1. veranderingen in denken en beleving, 2 . veranderingen in het functioneren en 3 . veranderingen in sociale relaties. Ter illustratie geven we hier enkel passages uit de interviews weer.

ad 1. Veranderingen in denken en beleven:

$\mathrm{Bij}$ de eerste meting noemen de meeste patiënten als reactie op de diagnose angst, verbijstering en het instorten van hun wereld. In de beginfase van de ziekte bepaalt de ziekte vaak voortdurend hun gedachten: "Het gaat nooit uit je gedachten, je bent er dag en nacht mee bezig. Je draagt het ziek-zijn met je mee, elke dag".

Patiënten geven bovendien regelmatig aan te gaan piekeren over de dood en rapporteren emotioneel, depressief gedrag en huilbuien. Daarnaast werd ook regelmatig het veranderende toekomstperspectief genoemd: "Ik ben mijn leven anders gaan bekijken, ik maak geen toekomstplannen meer. Ik bekijk het niet meer op lange termijn, ik probeer van de dag in de dag te leven". 
Enkele respondenten wijzen behalve op angst en verbijstering ook op positicve veranderingen: "Ik ben bewuster geworden van dingen, geniet meer van het leven. Ik pak wat ik pakken kan. Ergens is het een soort verrijking in je leven en van de andere kant zou je onbezorgder leven als je niet ziek was".

Na verloop van tijd slijten de negatieve gevoelens, zeker als bij de controles blijkt dat alles goed is. Toch hebben patiënten regelmatig terugkerende angsten, vooral voordat ze weer op controle moeten of wanneer er weer klachten optreden.

"Ik denk er steeds minder aan, maar toch als ik iets voel dan ben ik weer bang".

\section{ad 2. Veranderingen in functioneren:}

De meeste patiënten worden op de een of andere manier beperkt in hun functioneren. Veel patiënten noemen: niet meer kunnen sporten of werken, alles langzamer doen dan normaal, meer thuis zitten, alleen kleinigheidjes in het huishouden doen. Omdat men vaak sneller moe is doet men wat rustiger aan in het algemeen. Na verloop van tijd kan men activiteiten vaak weer oppakken, zeker als het gaat om een gunstig ziektebeloop: "Ik ben gewoon doodop. In het huishouden doe ik alleen wat kleine dingen, verder een boekje lezen. Met sporten ben ik ook gestopt. Ze zeggen dat het ook van de bestraling komt, dat moe zijn. Hopelijk kan ik volgende maand weer parttime gaan werken"

ad 3. Veranderingen in sociale relaties:

Ten aanzien van sociale relaties worden positieve en negatieve veranderingen beschreven. Volgens veel mensen is de relatie met de partner en anderen in de directe omgeving beter geworden: "De band is sterker geworden, je gaat meer praten, meer over inhoudelijke dingen. We zijn wat meer bij de dingen stil blijven staan, het benadrukt wat je aan elkaar hebt".

Anderzijds kan het ziek-zijn ook leiden tot problemen in de relatie: "Hij maakt het me wel eens moeilijk, ik moet erg oppassen met wat ik zeg, hij is lastiger geworden sinds hij ziek is geworden".

Enkele malen geven centrale verzorgers aan dat de spanningen hen te veel worden: zij worden zelf overspannen, zijn overbezorgd of durven het huis niet meer te verlaten omdat ze bang waren om de patiënt alleen te laten. Bij de vervolgmetingen klagen sommige patiënten over de reacties van vrienden en kennissen : "Het ergste vind ik dat iedereen denkt, ze tilt er niet zo zwaar aan, je ziet niks meer. Maar ze gaan voorbij aan wat je voelt. Uiteindelijk moet je het toch in je eentje verwerken".

Bovenstaande citaten dienen vooral als illustratie. In deze dissertatie worden geen verdere resultaten van kwalitatief onderzoek weergegeven. We beperken ons verder tot de kwantitatieve gegevens. 


\subsubsection{Samenhang tussen de indicatoren van kwaliteit van leven}

Nagegaan is hoe de verschillende gemeten dimensies met elkaar samenhangen. Daartue zijn Pearson correlaties berekend. Uit de correlatiematrix in tabel 5.3 blijkt dat op alle drie de meetmomenten steeds een redelijke grote samenhang bestaat tussen lichamelijke en psychische klachten. Het globale oordeel over het onwelbevinden correleert steeds redelijk hoog met psychische en lichamelijke klachten. Het functioneren blijkt steeds significant te correleren met lichamelijke c.q. psychische klachten alsmede met het globale oordeel.

Tabel 5.3 Pearson correlaties indicatoren kwaliteit van leven op drie meetmomenten $(\mathbf{n}=67)^{*}$.

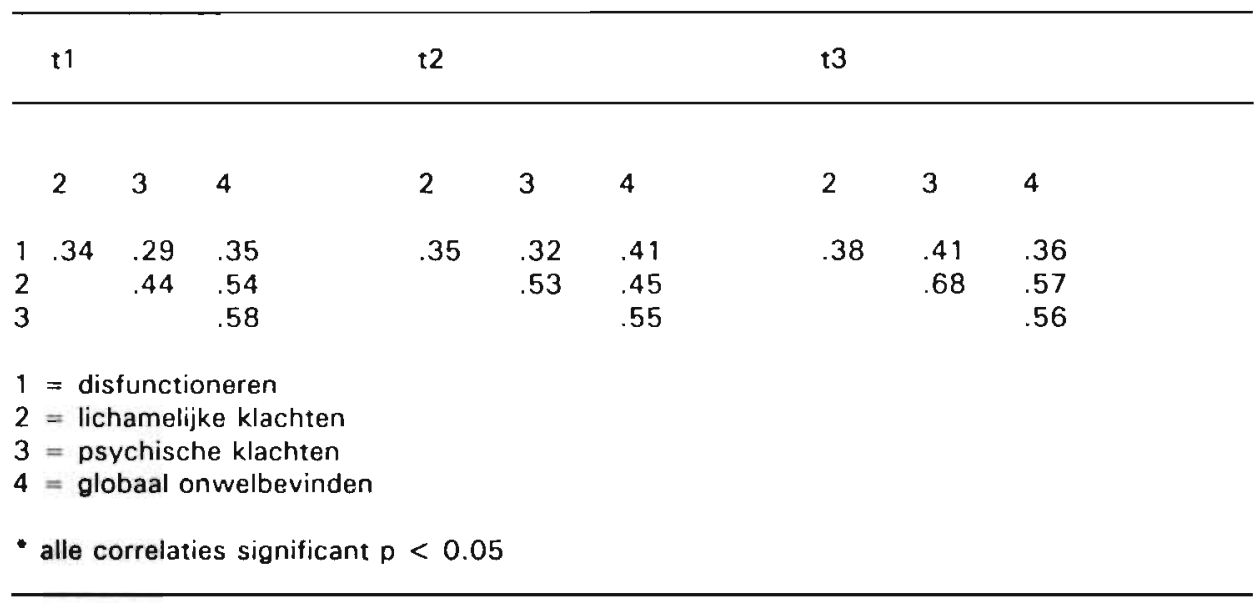

Omdat er bovendien sprake is van een duidelijke tendens, namelijk een vooruitgang in de loop van de tijd, is een principale componentenanalyse uitgevoerd op de vier gebruikte maten, bij alle drie de metingen apart. Uit deze analyses blijkt dat we kunnen spreken van een één-factorstructuur. Deze ene factor verklaart bij de eerste meting $57 \%$ van de variantie, bij de tweede meting $58 \%$ en bij de derde meting $63 \%$. In tabel $5.4 \mathrm{zijn}$ de factorladingen voor de drie metingen weergeven.

Tabel 5.4 Factorladingen indicatoren voor kwaliteit van leven op de drie meetmomenten $(n=67)$.

Lichamelijke klachten

Psychische klachten

Globaal onwelbevinden

Disfunctioneren (sip) t1

.78

.78

.84

.61 t2

.77

.81

.80

65 t3

.85

.86

.80

.64 
Op theoretische gronden kan een onderscheid gemaakt worden tussen (dis)functioneren of sickness en (on)welbevinden of illness. Het gaat bij sickness vooral om de gedragsmatige aspecten van kwaliteit van leven en bij illness om belevingsaspecten. Op empirische gronden blijkt dit onderscheid echter niet zo duidelijk te zijn: onwelbevinden en disfunctioneren laden hoog op één factor. De gebruikte dimensies hangen sterk met elkaar samen. De gevonden factor is te interpreteren als een oordeel over kwaliteit van leven, dat gebaseerd is op verschillende dimensies. Vanwege de eenduidige factorstructuur wordt bij de verdere analyses in volgende hoofdstukken geen onderscheid gemaakt tussen de vier gebruikte maten voor kwaliteit van leven. Met het oog op variabelenreductie zal in het vervolg gebruik gemaakt worden van een samengestelde variabele, verder te noemen 'kwaliteit van leven', die gevormd is door de z-scores van de vier gebruikte maten bij elkaar op te tellen. Er blijft dus éen afhankelijke variabele over. Deze variabele geeft geen absolute score weer maar een relatieve score van de respondenten ten opzichte van de totale patiëntengroep. Een hoge score duidt op een relatief goede kwaliteit van leven.

Omdat het gestandaardiseerde scores betreft, is het niet mogelijk om een multivariate variantie analyse te doen voor herhaalde metingen. Wel is voor elke meting apart het verschil in scores tussen de Noord-Limburgse en Maastrichtse groep onderzocht met een t-toets. In tabel 5.5 worden de gemiddelde scores op de samengestelde variabele 'kwaliteit van leven' weergegeven bij de drie metingen.

Tabel 5.5 Gemiddelde scores kwaliteit van leven naar responsgroep $(n=67$ ).

\begin{tabular}{|c|c|c|c|c|}
\hline \multicolumn{5}{|l|}{1} \\
\hline Noord - Limburg & $\langle n=51)$ & 0.5 & 2.6 & $*$ \\
\hline Maastricht & $(n=16)$ & -1.6 & 3.7 & \\
\hline \multicolumn{5}{|l|}{ t2 } \\
\hline Noord -Limburg & $(n=51)$ & 0.5 & 2.7 & $\cdots$ \\
\hline Maastricht & $(n=16)$ & -1.6 & 3.6 & \\
\hline \multicolumn{5}{|l|}{$\mathrm{t} 3$} \\
\hline Noord-Limburg & $(n=51)$ & 0.2 & 3.1 & n.s \\
\hline Maastricht & $(n=16)$ & -0.7 & 3.2 & \\
\hline
\end{tabular}

Nog duidelijker dan in de eerder getoonde tabellen komt naar voren dat de Maastrichtse groep een negatievere kwaliteit van leven ervaart dan de NoordLimburgse groep.

Op grond van de verschillen in de samenstelling van de groepen die in hoofdstuk vier zijn beschreven, was dit te verwachten. De patiënten in Maastricht zijn immers gemiddeld langer ziek dan de patiënten in Noord-Limburg, de Maastrichtse groep bevat relatief meer mensen met metastasen en relatief meer patiënten die een chemotherapie en/of radiotherapie hebben ondergaan. Door de significante 
verschillen tussen beide groepen wat ziektekenmerken, sociaal-demografische kenmerken en de verschillen ten aanzien van kwaliteit van leven betreft, wordt de noodzaak om de resultaten voor Noord-Limburg en Maastricht apart te analyseren en te presenteren steeds groter.

\subsection{Veranderingen in kwaliteit van leven op individueel niveau}

Behalve de veranderingen van de gemiddelde scores vormen ook veranderingen op individueel niveau onderwerp van studie. Dat de kwaliteit van leven, gemiddeld genomen, verbetert in de loop der tijd zegt nog niets over de veranderingen op individueel niveau.

De stabiliteit van de scores op de vier afzonderlijke maten en de samengestelde variabele kwaliteit van leven staan in tabel 5.6 beschreven. Pearson correlaties zijn berekend om na te gaan in hoeverre de scores fluctueren gedurende de follow-up periode.

Voor psychische klachten, voor het functioneren en voor de totaalscore voor kwaliteit van leven is de stabiliteit hoog. Dat wil zeggen dat patiënten die op de eerste meting hoog scoren op de vervolgmetingen ook hoog scoren. De lichamelijke kJachten en het globale welbevinden laten een minder stabiel beeld zien.

Tabel 5.6 Stabiliteit van de scores op de maten voor kwaliteit van leven. Pearson correlaties $(n=67) *$.

\begin{tabular}{llllll}
\hline & lich. klachten & psych. klachten SiP & onwelbevinden & $\begin{array}{c}\text { kwaliteit } \\
\text { leven }\end{array}$ \\
$\mathrm{t} 1-\mathrm{t} 2$ & .64 & .74 & .74 & .49 & .82 \\
$\mathrm{t} 1-\mathrm{t} 3$ & .66 & .70 & .74 & .38 & .74 \\
$\mathrm{t} 2-\mathrm{t} 3$ & .50 & .68 & .90 & .43 & .73 \\
$*$ alle correlaties significant $\mathrm{P}<0.05$ & & & \\
\hline
\end{tabular}

Om veranderingen op individueel niveau te onderzoeken zijn verschilscores berekend tussen de scores op de vier afzonderlijke maten voor kwaliteit van leven. Naar aanleiding van het lineaire beloop van 'kwaliteit van leven' is in deze fase van het onderzoek de keuze gemaakt om alleen de eerste en derde meting en het verschil daartussen te analyseren. De tweede meting levert in dit geval geen extra informatie op.

Aan de hand van deze verschilscores $(t 1, t 3)$ is een classificatie gemaakt van respondenten die een zekere mate van vooruitgang vertonen ten opzichte van de totale patiëntengroep, respondenten die achteruit gaan ten opzichte van de groep en respondenten die ongeveer hetzelfde niveau van kwaliteit van leven behouden. Bij die classificatie is, in navolging van Cohen (1977) en de Witte (1991), een bepaald criterium gebruikt: 0.5 vermenigvuldigd met de standaarddeviatie van de verschilscores. Patiënten die ten aanzien van de verschilscores in kwaliteit van leven hoger dan 
de helft van de standaarddeviatie scoren, zijn ingedeeld bij de groep die achteruit is gegaan. Patiënten die lager scoren dan de helft van de standaarddeviatie zijn ingedeeld bij de groep die vooruit is gegaan. De overige patiënten zijn geclassificeerd in de groep die (ongeveer) gelijk is gebleven. De classificatie geldt zowel voor Noord-Limburg als voor Maastricht. In tabel 5.7 is weergegeven hoeveel patiënten vooruit zijn gegaan, achteruit, dan wel gelijk zijn gebleven.

Tabel 5.7

Classificatie van respondenten naar verschilscores $(t 1, t 3)$ op de maten voor kwaliteit van leven, Noord-Limburg en Maastricht ( $n=67$ ).

Noord-Limburg $(n=51)$

Maastricht $(n=16)$

Disfunctioneren:

achteruit

gelijk

$8(16 \%)$

vooruit

$21(41 \%)$

$22(43 \%)$

$7(44 \%)$

$9(56 \%)$

Lichamelijk klachten:

achteruit

$9(18 \%)$

$2(13 \%)$

gelijk

$23(45 \%)$

$8(50 \%)$

vooruit

$19(37 \%)$

$6(38 \%)$

Psychische klachten:

achteruit

$14(27 \%)$

$2(13 \%)$

$17(33 \%)$

$4(25 \%)$

vooruit

$20(39 \%)$

$10(63 \%)$

Globaal onwelbevinden:

achteruit

gelijk

$22(43 \%)$

$4(25 \%)$

$14(28 \%)$

$3(19 \%)$

vooruit

$15(29 \%)$

$9(56 \%)$

Uit tabel 5.7 blijkt dat zowel in Noord-Limburg als in Maastricht wat het disfunctioneren en de klachten betreft, relatief veel patiënten gelijk blijven of vooruit gaan en dat een klein percentage achteruit gaat. Dit is in overeenstemming met wat gevonden werd ten aanzien van de veranderingen op de gemiddelde scores. Wat opvalt in tabel 5.7 is dat met name bij het globale onwelbevinden en de psychische klachten relatief meer patiënten uit Maastricht vooruit gaan dan patiënten in Noord-Limburg. Dit verschil is significant $(\mathrm{p}<0.05)$. Deze bevinding is mogelijk mede te verklaren vanuit een fenomeen dat zich voordoet bij longitudinaal onderzoek en dat in deze context genoemd moet worden: regressie naar het gemiddelde. Dit betekent dat patiënten die zeer goed scoren op kwaliteit van leven op de eerste meting meer kans hebben om bij vervolgmetingen slechter te scoren. Patiënten die zeer laag scoren daarentegen hebben een grotere kans om in de vervolgmeting hoger te scoren. In het begin van dit hoofdstuk is al geconcludeerd dat de patiënten in Maastricht, op een aantal aspecten, een slechtere kwaliteit van leven rapporteren dan de patiënten uit Noord-Limburg. $\mathrm{Zij}$ hebben daardoor een grotere kans om vooruit te gaan. Door regressie naar het gemiddelde kunnen verschilscores in een bepaalde mate vertekend 
zijn. Om na te kunnen gaan in hoeverre dit probleem zich voordoet in ons onderzoek, is de correlatie berekend tussen de scores op de samengestelde variabele kwaliteit van leven van de eerste meting en de verschilscores tussen de eerste en derde meting. Deze correlatie bedraagt $-.30(p<0.10)$. Dit betekent dat er inderdaad sprake is van een zeker regressie-effect: de verschilscores hangen negatief samen met de beginscores; hoge scores worden lager, lage scores worden hoger. Om na te gaan in hoeverre regressie naar het gemiddelde optreedt voor beide groepen, is voor de afzonderlijke groepen de correlatie berekend tussen de scores op de eerste meting en de verschilscores tussen de eerste en derde meting. In NoordLimburg bedraagt de correlatie - .25, ( $p<0.05)$, in Maastricht - .3I $(p<0.10)$. De gevonden correlaties zijn niet van dien aard dat onoverzienlijke problemen in de analyses worden verwacht. Er moet echter wel rekening worden gehouden met enige vertekening. In hoofdstuk 10 wordt op dit probleem verder ingegaan.

De verschilscores zijn voor Noord-Limburg en Maastricht apart, opnieuw geclassificeerd, omdat voor de groepen apart een ander gemiddelde en standaarddeviatie van de verschilscores geldt. Deze classificatie levert echter weinig andere resultaten op dan die zijn weergegeven in tabel 5.7. Alleen in Maastricht trad een kleine verandering op: zes patiënten blijven op hetzelfde niveau functioneren en tien gaan vooruit. Ten aanzien van de psychische klachten blijken bij aparte classificatie twee respondenten achteruit te gaan, zeven hetzelfde te blijven en zeven patiënten vooruit te gaan.

Om na te kunnen gaan in hoeverre respondenten in totaal vooruit, achteruit of gelijk blijven scoren op kwaliteit van leven, zijn aan de classificaties codes toegekend. Patiënten die vooruit gaan, bijvoorbeeld in hun functioneren, krijgen code 3, patiënten die ongeveer hetzelfde blijven scoren krijgen code 2 en patiënten die achteruit gaan, krijgen code 1. Hetzelfde is gedaan voor de klachten en het globale onwelbevinden. Deze codes zijn bij elkaar opgeteld. Als een patiënt op alle vier de maten vooruit gaat scoort hij 12, iemand die op alle aspecten achteruit gaat scoort 4. In tabel 5.8 wordt de verdeling van deze totale veranderingsscores weergegeven voor de volledige-responsgroepen.

Tabel 5.8 Classificatie van respondenten naar de totale veranderingsscores van kwaliteit van leven, Noord-Limburg en Maastricht $(n=67)$.

totaalscores

Noord-Limburg $(n=51)$

Maastricht $(n=16)$

$\begin{array}{rrr}4 & 3 & - \\ 5 & 1 & - \\ 6 & 1 & - \\ 7 & 11 & 2 \\ 8 & 10 & 4 \\ 9 & 9 & 1 \\ 10 & 9 & 3 \\ 11 & 6 & 5 \\ 12 & 1 & 1\end{array}$

4 betekent achteruit op alle aspecten, 12 vooruit op alle aspecten 
Omdat het in dit onderzoek om kleine getallen gaat is een tweedeling gemaakt van patiënten die negen of hoger scoren (patiēnten die vooruit gaan) en patiënten die lager scoren (patiënten die gelijk blijven of achteruit gaan). Deze indeling (zie tabel 5.8 ) zal in de longitudinale analyses worden gebruikt. In Noord-Limburg zijn dus vijfentwintig patiënten vooruit gegaan en zesentwintig patiënten achteruit gegaan ofwel gelijk gebleven. In Maastricht gingen tien patiënten vooruit, terwijl zes patiënten ongeveer gelijk bleven of achteruit gingen.

\subsection{Samenvatting en conclusies}

In dit hoofdstuk is een beschrijving gegeven van de kwaliteit van leven van patiënten en de veranderingen daarbinnen op groeps- en op individueel niveau. Zoals verwacht werd is op het moment van de eerste meting de kwaliteit van leven, in de zin van disfunctioneren en klachten, het meest aangetast. Veel patiënten rapporteren problemen met huishoudelijke activiteiten, recreatie en vrije tijd, slapen en mobiliteit. Verder komen de klachten als moeheid, pijnlijke spieren, gespannen zijn, slapeloosheid en zenuwachtigheid vaak voor. Dit is verklaarbaar omdat in het eerste stadium van het ziek-zijn, (dat in het het teken staat van diagnosestelling en behandeling) lichamelijke beperkingen, onzekerheden en vraagstukken omtrent leven en dood een belangrijke rol spelen. Opmerkelijk is ook dat ondanks de beperkingen in het functioneren en de klachten, het globale welbevinden gemiddeld goed is. Patiënten zijn tevreden over het leven en voelen zich in het algemeen redelijk goed. Er zijn enkele belangrijke verschillen gevonden tussen de patiënten in NoordLimburg en de patiënten in Maastricht. Met name op de globale maat voor onwelbevinden en enkele aspecten van het functioneren (lopen, sociale interactie, emotioneel gedrag) rapporteren de Maastrichtse patiënten een slechtere kwaliteit van leven dan de Noord-Limburgse groep.

Patiēnten, zowel in Noord-Limburg als in Maastricht, rapporteren in de loop van de periode dat ze zijn gevolgd gemiddeld minder lichamelijke en psychische klachten en gaan beter functioneren. Het globale gevoel van welbevinden verandert gemiddeld niet in de tijd; mensen blijven gedurende de hele periode tevreden over hun leven en zich goed voelen. Het is mogelijk dat patiënten, ondanks de klachten en het verminderd functioneren in het dagelijks leven, hun leven positief blijven evalueren door het aanpassingsvermogen waarover mensen beschikken. De criteria om tot een globaal oordeel te komen verschuiven als het ware met de toestand van de patiënt mee.

Omdat we in het algemeen kunnen spreken van een lineair beloop van kwaliteit van leven is besloten om bij longitudinale analyses alleen de eerste en de derde meting in de analyses te betrekken. Ook de wenselijkheid van datareductie heeft meegespeeld in deze beslissing.

Om te komen tot reductie van het aantal variabelen is een principale componenten analyse uitgevoerd op de vier maten voor kwaliteit van leven. Er bleek één factor over te blijven. Op grond hiervan werd besloten de vier maten samen te voegen tot één samengestelde variabele die in de volgende hoofdstukken als afhankelijke variabele gebruikt gaat worden onder het label kwaliteit van leven. 
Behalve de veranderingen op groepsniveau zijn ook de veranderingen op individueel niveau bestudeerd. Het blijkt dat het functioneren, psychische klachten en de scores op de samengestelde variabele 'kwaliteit van leven' vrij stabiel blijven in de tijd. De scores op lichamelijke klachten en het globale onwelbevinden blijken minder stabiel te zijn.

Vervolgens zijn verschilscores $(t 1, t 3)$ berekend en is een classificatie gemaakt van patiënten die voor- of achteruit gaan of ongeveer gelijk scoren op de eerste en derde meting. Hierbij blijkt dat relatief meer patiënten uit Maastricht dan patiënten uit Noord-Limburg vooruit gaan. Dit is deels verklaarbaar vanuit het fenomeen regressie naar het gemiddelde. Patiënten uit Maastricht beginnen met een slechtere score bij de eerste meting en hebben dus statistisch gezien meer kans om vooruit te gaan, terwijl patiënten uit Noord-Limburg beginnen met een relatief goede score en dus meer kans hebben om achteruit te gaan. In Noord-Limburg gaan 25 patiënten vooruit in kwaliteit van leven en 26 gaan achteruit of blijven ongeveer gelijk scoren. In Maastricht gaan in totaal tien patiënten vooruit en zes blijven gelijk scoren of gaan achteruit.

Op grond van verschillen in sociaal-demografische kenmerken, ziektekenmerken en verschillen in de scores op kwaliteit van leven tussen de Noord-Limburgse en Maastrichtse groep hebben we besloten in het vervolg alleen gegevens van de NoordLimburgse groep te analyseren en te presenteren. Een ander argument om alleen de Noord-Limburgse groep te gebruiken is dat over deze groep gegevens bekend zijn over de risicopopulatie. De groep uit Maastricht zal in een latere fase worden gebruikt als een vergelijkingsgroep; er zal dan worden nagegaan of de gevonden resultaten in Noord-Limburg ook van toepassing zijn op de Maastrichtse situatie.

In de volgende hoofdstukken zal door middel van bivariate en multivariate analyses worden nagegaan welke ziektegebonden factoren, kenmerken van zorg en persoonsgebonden kenmerken van invloed zijn op kwaliteit van leven.

Hierbij moet worden opgemerkt dat bij veel analyses de significantiegrens op $\mathrm{p}=$ 0.10 wordt gesteld. De motivatie hiervoor is dat het gaat om een explorerend onderzoek met een kleine populatie. We realiseren ons echter dat daarmee de toevalskans toeneemt. 


\section{Kenmerken van de ziekte en de behandeling, sociale positie en be- heersingsoriëntatie in relatie tot kwaliteit van leven}

In dit hoofdstuk worden ziekte- en behandelingskenmerken en hun relatie tot kwaliteit van leven behandeld (6.1). De ziekte- en behandelingskenmerken zijn al beschreven in hoofdstuk 4 . In transversale analyses wordt nagegaan in hoeverre de verschillende kenmerken van ziekte en behandeling met elkaar samenhangen en in welke mate er sprake is van samenhang tussen de verschillende kenmerken en de kwaliteit van leven op het eerste en derde meetmoment. Als maat voor kwaliteit van leven is de samengestelde variabele gebruikt (opgetelde z-scores van de vier indicatoren voor kwaliteit van leven). Daarnaast zijn de ziekte- en behandelingskenmerken gerelateerd aan het beloop van kwaliteit van leven. Ten aanzien van het beloop van kwaliteit van leven hebben we de patiënten ingedeeld zoals in paragraaf 5.2 is beschreven.

In paragraaf 6.2 wordt een beschrijving gegeven van de relatie tussen de verschillende indicatoren voor sociale positie en hun samenhang met kwaliteit van leven en het beloop daarvan. Tot slot wordt ingegaan op de beheersingsoriëntatie in relatie tot kwaliteit van leven (6.3).

\subsection{Ziektekenmerken en behandeling}

In het onderzoek zijn de volgende kenmerken van ziekte en behandeling opgenomen: de diagnose, de ziekteduur in maanden, de overlevingsprognose volgens de artsen (huisarts, specialist), het stadium van de ziekte en de aard van de behandeling. We gaan, wat de ziektekenmerken betreft, steeds uit van de gegevens op het eerste meetmoment. $\mathrm{Bij}$ de vervolgmetingen ontbreken te veel gegevens.

Wat de diagnoses en de behandelingen betreft, hebben we te maken met heterogeniteit (zie hoofdstuk 4). Van de 51 patiënten hebben er twaalf metastasen. Het gaat daarbij steeds om lymphekliermetastasen. Van vijftig patiënten is de overlevingsprognose door de huisartsen en/of specialisten geschat (zie hoofdstuk 3). Eenendertig patiënten hebben een goede tot zeer goede overlevingsprognose, twaalf een matige-, en zeven patiënten hebben een slechte tot zeer slechte 
prognose. Patiënten zijn gemiddeld 3.5 maanden ziek met een minimum van een en een maximum van zeven maanden.

Het stadium van de ziekte (metastasen of niet) blijkt samen te hangen met de overlevingsprognose $(r=.44, p<0.05)$. Deze variabelen (stadium en prognose) zijn daarom samengevoegd tot én variabele, die we 'ernst van de ziekte' noemen. De scores op de overlevingsprognose zijn daarbij gedichotomiseerd in 'goede/zeer goede prognose' en 'matige tot zeer slechte prognose'. Patiënten zonder metastasen en een (zeer) goede prognose vormen de eerste categorie, patiënten met of een slechte prognose of metastasen de tweede categorie en patienten met zowel metastasen als een slechte prognose vormen de derde categorie.

Er is een verband tussen de aard van de behandeling en het stadium van de ziekte; patiënten met metastasen krijgen een uitgebreidere behandeling (in de vorm van combinaties van operatie en chemo- c.q. radiotherapie) dan patiënten zonder metastasen $\left(\mathrm{chi}^{2}=14.4 ; \mathrm{p}<0.05\right)$. De andere kenmerken vertonen geen onderlinge samenhang.

Om de samenhang tussen de ziektekenmerken en de kwaliteit van leven op de verschillende meetmomenten te bepalen zijn, waar mogelijk, Pearson correlaties berekend. Verder zijn zijn t-testen en én-weg variantieanalyses voor meervoudige vergelijkingen uitgevoerd. Tabellen $6.1 \mathrm{a}$ en $\mathrm{b}$ geven de bevindingen weer.

De ernst van de ziekte, geïndiceerd door de overlevingsprognose en het stadium van de ziekte, blijkt steeds samen te hangen met de kwaliteit van leven. Patiënten met een slechte overlevingsprognose rapporteren een lagere kwaliteit van leven, evenals patiënten met metastasen (op het eerste meetmoment). De duur van de ziekte (het tijdsverloop sinds diagnose) blijkt geen significante samenhang te vertonen met kwaliteit van leven.

Tabel 6.1a Samenhang tussen ziektekenmerken en kwaliteit van leven op het eerste en derde meetmoment. Pearson correlatie $(n=51)$.

Overlevingsprognose

Duur

Ernst (prog. + stadium)

p $<<0.10, * 0.05$

$$
-.36 *
$$

$-.24^{*}$

.04

$-.23^{*}$ 


\begin{tabular}{|c|c|c|c|c|c|c|c|}
\hline \multicolumn{4}{|c|}{ t1 } & \multicolumn{4}{|c|}{ t3 } \\
\hline & $\mathrm{n}$ & gem & s.d & $p$ & gem & s.d & $p$ \\
\hline \multicolumn{8}{|l|}{ Stadium } \\
\hline geen metastasen & 39 & 0.4 & 2.6 & & 0.3 & 2.8 & \\
\hline metastasen & 12 & -1.2 & 3.4 & $\cdot$ & -0.9 & 3.2 & n.s \\
\hline \multicolumn{8}{|l|}{ Diagnose } \\
\hline Borst & 19 & -0.1 & 2.9 & & 0.3 & 3.2 & \\
\hline Long & 6 & -0.9 & 2.4 & & -1.3 & 1.8 & \\
\hline Maag-darm & 11 & -0.3 & 2.9 & & 0.1 & 3.7 & \\
\hline Anders & 15 & 0.7 & 3.1 & n.s & 0.1 & 3.1 & n.s \\
\hline \multicolumn{8}{|l|}{ Behandeling } \\
\hline Operatie & 28 & 0.2 & 2.6 & & 0.2 & 2.9 & \\
\hline Bestraling & 3 & 1.6 & & & 0.4 & & \\
\hline $\mathrm{Op}+$ chemo & 2 & -2.7 & & & -3.5 & & \\
\hline Op + bestraling & 13 & 0.3 & 2.9 & & 0.3 & 3.1 & \\
\hline $\mathrm{Op}+$ best + chemo & 5 & -1.6 & 4.5 & n.s & -0.5 & 4.9 & n.s \\
\hline$* p<0.10$ & & & & & & & \\
\hline
\end{tabular}

Tussen de verschillende diagnosegroepen zijn geen significante verschillen gevonden hetgeen geweten kan worden aan de kleine aantallen patiënten. Vermeldingswaard is dat patiënten met longkanker gemiddeld relatief laag scoren, dat wil zeggen een slechte kwaliteit van leven rapporteren.

Ook tussen de verschillende behandelingsmethoden zijn bij de énweg-variantie analyses geen significante verschillen gevonden. Bij de vergelijking tussen patiënten die wél en patiēnten die gén chemotherapie hebben ondergaan, blijkt een verschil te bestaan; chemotherapiepatiënten rapporteren op het eerste meetmoment een slechtere kwaliteit van leven $(p<0.05)$.

Om het beloop van kwaliteit van leven te bestuderen in relatie tot de onafhankelijke variabelen zijn steeds twee groepen met elkaar vergeleken: patiënten die achteruit zijn gegaan of gelijk zijn gebleven $(n=26)$ en patiënten die vooruit zijn gegaan $(n=25)$ in kwaliteit van leven.

In tabel 6.2 wordt weergegeven hoe de twee groepen zijn verdeeld naar ziektekenmerken. Verschillen tussen deze twee groepen zijn getoetst met behulp van een chi-kwadraat-, of een t-toets. Er zijn geen significante verschillen gevonden tussen beide groepen wat de ziektekenmerken betreft. 

vooruit gaan of achteruit gaan/gelijk blijven, chi -kwadraat, $t$-test $(n=51)$.

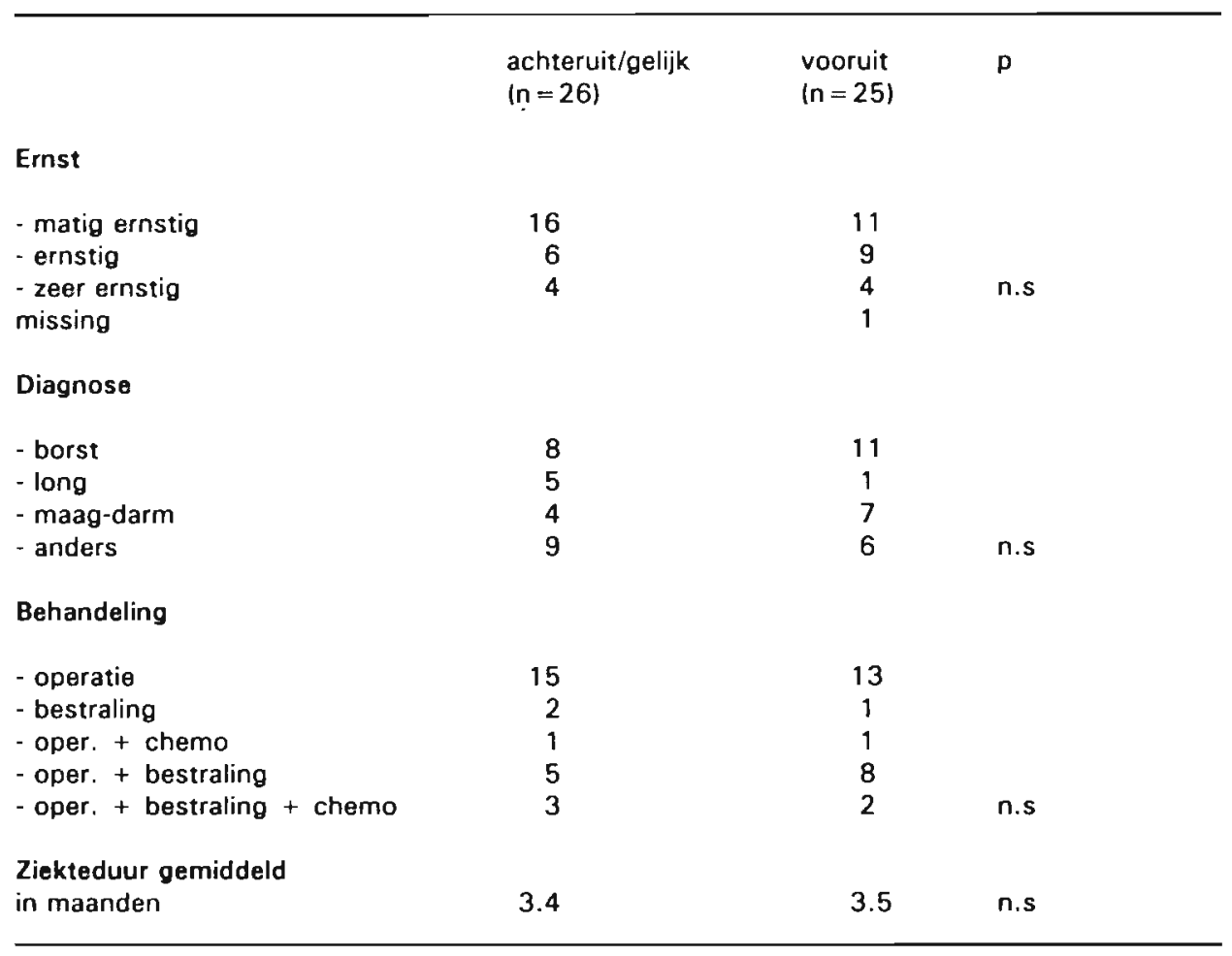

Het beloop van kwaliteit van leven zou verklaard kunnen worden door wijzigingen die zich hebben voorgedaan in de objectieve ziekte- of behandelingskenmerken; bijvoorbeeld door het optreden van metastasen of het ondergaan van een behandeling. Zoals al eerder in dit hoofdstuk is beschreven, beschikken we bij de tweede en derde meting niet over voldoende objectieve gegevens wat de ziektekenmerken betreft. Het aantal vragenlijsten dat door specialisten bij de twee vervolgmetingen is beantwoord, is te verwaarlozen $(n=17)$. Van de volledige responsgroep in Noord-Limburg $(n=51)$ hebben 45 huisartsen vragen met betrekking tot objectieve ziekte- en behandelingskenmerken op de tweede of derde meting beantwoord.

De oordelen over prognose en stadium van de ziekte blijken nauwelijks te veranderen in de tijd. Bij slechts twee patiënten vermelden de huisartsen bij de tweede of derde meting geen metastasen, terwijl dat zij bij de eerste meting wel metastasen rapporteerden bij die patiënten. Bij de derde meting blijkt dat bij één patiënt botmetastasen zijn opgetreden. Volgens de huisartsen verbetert de prognose voor drie patiënten en verslechtert de prognose voor twee patiënten.

De huisartsen geven ook een oordeel over de algemene toestand waarin de patiënt verkeert ten opzichte van de vorige meting. Met andere woorden zij beoordelen 
of de patiënten voor- of achteruit zijn gegaan ten opzichte van de vorige meting. De samenhang tussen deze oordelen en het beloop van de kwaliteit van leven van patiënten blijkt niet significant te zijn. In tabel 6.3 worden de oordelen van de huisartsen weergegeven voor de patiënten met een positief respectievelijk negatief/gelijk beloop van kwaliteit van leven.

Een klein aantal patiënten $(n=9)$ heeft tussen de eerste en tweede meting een medische behandeling ondergaan. Tussen de tweede en derde meting werden slechts zes patiënten behandeld. $\mathrm{Er}$ is geen significante samenhang gevonden tussen het ondergaan van deze behandelingen en het beloop van kwaliteit van leven.

Tabel 6.3 Oordeel van de huisartsen over de toestand van de patiënt t.o.v vorige meting bij patiënten die vooruit gaan of achteruit gaan/gelijk blijven in kwaliteit van leven $(n=51)$.

$\begin{array}{ll}\text { kwaliteit leven } & \text { kwaliteit leven } \\ \text { vooruit } & \text { achteruit/gelijk } \\ (n=25) & (n=26)\end{array}$

Oordeel huisarts t2

Toestand van de patiēnt:

- gaat goed vooruit 6

- gaat langzaam vooruit 5

-blijft hetzelfde

- verslechtert langzaam

- verslechtert snel

missing

$\begin{array}{rr}6 & 6 \\ 5 & 1 \\ 0 & 15 \\ - & 1 \\ - & 1 \\ 4 & 2\end{array}$

Oordeel huisarts t3:

Toestand van de patiënt

- gaat goed vooruit

$\begin{array}{rr}4 & 3 \\ 3 & 2 \\ 13 & 15 \\ - & 3 \\ - & 1 \\ 5 & 2\end{array}$

- gaat langzaam vooruit

-blijft hetzelfde

- verslechtert langzaam

- verslechtert snel

missing

5

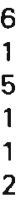

Omdat het gaat om de beoordeling van een beperkt aantal huisartsen, er maar in een klein aantal van de gevallen veranderingen optreden in de objectieve kenmerken en omdat er geen significant verband is gevonden tussen de beoordeling van de toestand van de patiënt door de huisarts en het beloop van kwaliteit van leven, worden alleen de gegevens over ziekte en behandeling van de eerste meting gebruikt in de verdere analyses.

\subsection{Sociale positie}

In hoofdstuk twee is beschreven hoe de sociale positie van mensen van invloed kan zijn op de kwaliteit van leven. Als indicatoren voor sociale positie zijn in het 
onderzoek opgenomen: geslacht, leeftijd, sociaal-economische status en burgerlijke staat. In hoofdstuk 4 zijn deze kenmerken beschreven.

Er bestaat een relatie tussen leeftijd en sociaal-economische status $(r=-.27, p<$ 0.10) : hoe hoger de leeftijd, hoe lager de sociaal-economische status. Burgerlijke staat kan verder niet meer worden meegenomen in de analyses omdat de veertien alleenstaanden op één respondent na, allen vrouwen zijn met borstkanker. Er is dus te weinig variatie in de groep alleenstaanden.

Om de relatie tussen de indicatoren voor sociale positie (leeftijd, ses en geslacht) en kwaliteit van leven te onderzoeken, zijn correlaties berekend en t-toetsen uitgevoerd. De resultaten hiervan zijn in tabel 6.4 a weergegeven.

De indicatoren voor sociale positie blijken geen samenhang te vertonen met kwaliteit van leven op het eerste en derde meetmoment.

Tabel 6.4a Samenhang tussen sociale positie en kwaliteit van leven $t 1, t 3$. Pearson correlaties en t-test $(n=51)$.

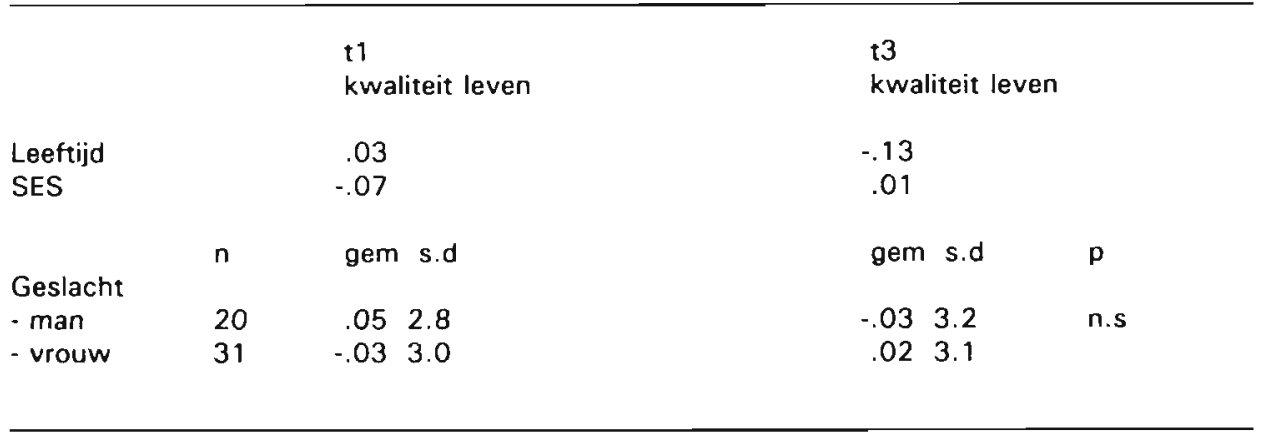

Door middel van t-toetsen en een chi $^{2}$-toets is vervolgens de relatie tussen sociale positie en het beloop van kwaliteit van leven bestudeerd.

Tabel 6.4b Samenhang tussen sociale positie en kwaliteit van leven bij patiēnten die vooruit gaan of achteruit gaan/gelijk blijven op kwaliteit van leven. t-test en $\operatorname{chi}^{2}(n=51)$.

\begin{tabular}{|c|c|c|c|c|c|}
\hline & \multicolumn{2}{|c|}{$\begin{array}{l}\text { kwaliteit leven } \\
\text { achteruit/gelijk( } n=26)\end{array}$} & \multicolumn{2}{|c|}{$\begin{array}{l}\text { kwaliteit leven } \\
\text { vooruit }(n=25 \text { ) }\end{array}$} & \multirow[b]{2}{*}{$p$} \\
\hline & gem & s.d & gem & s.d & \\
\hline Leeftijd & 64 & 9.6 & 58 & 13.3 & - \\
\hline SES & -.77 & 1.4 & .08 & 1.6 & $\cdots$ \\
\hline $\begin{array}{l}\text { Geslacht } \\
\text { - man } \\
\text { - vrouw }\end{array}$ & $\begin{array}{l}12 \\
14\end{array}$ & & $\begin{array}{c}8 \\
17\end{array}$ & & n.s \\
\hline
\end{tabular}


Wanneer we het beloop van kwaliteit van leven bezien, blijken leettijd en suciualeconomische status wél van belang te zijn (zie tabel 6.4.b.). Patiënten inet een negatief beloop van kwaliteit van leven zijn gemiddeld ouder en hebben een lagere sociaal-economische status dan de patiënten met ecn positief beloop van kwaliteit van leven. De sekse van de patiënt heeft geen invloed op het beloop.

\subsection{Beheersingsoriëntatie}

Bij de beheersingsoriëntatie zijn drie dimensies onderscheiden: een interne oriëntatie ten aanzien van het ontstaan van de ziekte, een religieuze oriëntatie en een oriëntatie die de beïnvloedbaarheid van het verloop van de ziekte genoemd is. In tabel 6.5 zijn de scores op deze dimensies weergegeven. Een aantal mensen had nogal wat problemen met het invullen van de vragenlijst. Hierdoor ontbreken veel waarden.

Tabel $6.5 \quad$ Vergelijking beheersingsoriëntatie op $\mathbf{t} 1$ en $\mathrm{t} 3$. $\mathrm{t}$-test-paren ( $\mathrm{n}=32-38$ ).

t1

n

Interne oriëntatie

t.a.v. ontstaan

Religieuze oriēntatie

Beinvloedbaarheid verloop gem s.d

$3.9 \quad 1.8$

7.4

22.6 t3

gem s.d p

$\begin{array}{lll}3.9 & 1.7 & \text { n.s }\end{array}$

$\begin{array}{lll}7.3 & 3.4 & \text { n.s }\end{array}$

$22.3 \quad 4.5 \quad$ n.s

De patiënten scoren gemiddeld laag (gerelateerd aan de theoretische range; tussen 3 en 12) op de dimensie interne oriëntatie met betrekking tot het ontstaan van de ziekte. Dat wil zeggen dat patiënten gemiddeld genomen, vinden dat zij geen invloed hebben gehad op het ontstaan van de ziekte. Op de religieuze oriëntatie is gemiddeld niet hoog gescoord (theoretische range 3-12). Gemiddeld genomen hebben patiënten niet het idee dat God of het geloof van invloed is op het ontstaan en het verloop van de ziekte. Een hoge gemiddelde score vinden we ten aanzien van de oriëntatie die we beïnvloedbaarheid van het verloop van de ziekte hebben genoemd. Blijkbaar hebben veel respondenten het idee dat ze zelf invloed kunnen uitoefenen op het verloop van de ziekte en dat personen uit de directe omgeving en artsen hierbij ook een belangrijke rol vervullen. De scores op de verschillende dimensies zijn goed vergelijkbaar met de resultaten uit het onderzoek van Pruyn (1988). Deze vindt bij 139 patiënten die behandeld zijn voor een hoofd-halscarcinoom de volgende gemiddelde scores: 5.6 voor interne oriëntatie ten aanzien van het ontstaan van de ziekte, 6.2 voor de religieuze oriëntatie en 20.2 voor hetgeen wij beïnvloedbaarheid van het verloop hebben genoemd. 
Er zijn in ons onderzoek, ten aanzien van de beheersingsoriëntatie, geen significante veranderingen in het groepsgemiddelde gevonden. Om na te gaan of de oriëntatie stabiel is in de onderzochte tijdsperiode zijn correlaties berekend tussen de scores op de drie meetmomenten. Stabiel wil hier zeggen dat respondenten die relatief laag scoren op het eerste meetmoment, ook bij de vervolgmetingen laag scoren en vice versa. De correlaties ten aanzien van de beïnvloedbaarheid van het verloop van de ziekte variëren tussen .60 en .77 , ten aanzien van de interne oriēntatie van het ontstaan tussen .70 en .77 en ten aanzien van de religieuze oriëntatie tussen .87 en .88 . Gezien de hoogte van de correlaties is besloten om de scores van de drie metingen te middelen. Daarmee is meteen het probleem ondervangen van de ontbrekende waarden. Op itemniveau zijn ontbrekende waarden vervangen door de score op een van de andere metingen of door het gemiddelde van scores op twee metingen. Zo zijn opnieuw scores op de drie dimensies gevormd.

De samenhang tussen de beheersingsoriëntatie en kwaliteit van leven is bepaald door het berekenen van correlaties. Voorts zijn met behulp van t-toetsen de patiënten met een negatief/gelijk beloop vergeleken met patiënten met een positief beloop van kwaliteit van leven (zie bijlage $E$ ). Uit deze analyses blijkt dat er geen samenhang bestaat tussen de beheersingsoriëntatie en de kwaliteit van leven of het beloop daarvan. We hebben besloten de variabele beheersingsoriëntatie verder niet meer mee te nemen in de analyses.

\subsection{Samenvatting en conclusies}

In dit hoofdstuk zijn een aantal kenmerken van de ziekte en behandeling, sociale positie en beheersingsoriëntatie beschreven en gerelateerd aan kwaliteit van leven en het beloop daarvan. In tabel 6.6 wordt samengevat welke variabelen significant correleren met de kwaliteit van leven op de drie meetmomenten en met het beloop van kwaliteit van leven.

De ernst van de ziekte blijkt samen te hangen met kwaliteit van leven en wel in de richting die verwacht werd. Patiënten die ernstiger ziek zijn, dat wil zeggen een slechtere overlevingsprognose en metastasen hebben, rapporteren een slechtere kwaliteit van leven dan mensen die minder ernstig ziek zijn. Bovendien blijken patiënten die chemotherapie hebben ondergaan, ook zoals verwacht, een slechtere kwaliteit van leven te hebben. Het gaat hier echter maar om zeven patiënten, zodat het niet zinvol is om deze variabele mee te nemen in de multivariate analyses die in hoofdstuk 9 worden beschreven. Er zijn geen verbanden gevonden tussen kwaliteit van leven en ziekteduur. Gezien de kleine aantallen kan over de relatie tussen diagnose en kwaliteit van leven niets geconcludeerd worden.

Tussen de ziekte- en behandelingskenmerken (zoals gemeten bij de eerste meting) en het beloop van kwaliteit van leven zijn geén significante relaties gevonden. Bij de tweede en derde meting hebben we, mede door de slechte respons van specialisten in de tweede meting, alleen de beschikking over objectieve gegevens met betrekking tot de ziektekenmerken van de huisartsen. De gegevens met betrekking tot ziektekenmerken, verzameld bij de huisartsen, laten zien dat er 
nauwelijks veranderingen optreden in de beoordeling van de prognose en het stadium van de ziekte. Slechts enkele patiënten ondergingen tijdens de follow-up periode nog een medische behandeling. Het is in ons onderzoek daarom niet zinvol om veranderingen in de objectieve medische gegevens te relateren aan het beloop van kwaliteit van leven.

Wat de indicatoren voor sociale positie betreft vonden we enkele interessante resultaten. De leeftijd en sociaal-economische status van de patiënt zijn gerelateerd aan het beloop van kwaliteit van leven. Mensen die een negatief beloop hebben van kwaliteit van leven of ongeveer gelijk blijven scoren, zijn gemiddeld ouder en hebben een lagere sociaal-economische status dan de patiënten met een positief beloop van kwaliteit van leven.

De verschillende dimensies van de beheersingsoriëntatie vertonen zowel bij de transversale als de longitudinale analyses geen samenhang met kwaliteit van leven. Dit is in strijd met onze verwachting dat een interne oriëntatie positief correleert met kwaliteit van leven. Het is echter wel consistent met een onderzoek van Ruf-Dirksen (1990) naar de relatie tussen beheersingsoriëntatie en kwaliteit van leven bij kankerpatiënten. Ook zij vindt weinig samenhang tussen interne beheersingsoriëntatie en kwaliteit van leven.

In de multivariate- analyses (zie hoofdstuk 9) worden de volgende variabelen gebruikt: ernst van de ziekte, leeftijd en sociaal-economische status. Als criterium is een significante samenhang met kwaliteit van leven bij de transversale en/of longitudinale analyses gehanteerd. De behandeling die de patiënt heeft ondergaan, wordt vanwege de zeer kleine aantallen niet meegenomen in vervolganalyses.

Tabel 6.6 Samenvatting van de bivariate verbanden tussen kwaliteit van leven en ziektekenmerken, sociale positie en beheersingsoriëntatie.

\begin{tabular}{|c|c|c|c|}
\hline & $\mathrm{t1}$ & t3 & beloop \\
\hline - ernst & + & + & 0 \\
\hline - duur & 0 & 0 & 0 \\
\hline - diagnose & 0 & 0 & 0 \\
\hline - behandeling & + & 0 & 0 \\
\hline - leeftijd & 0 & 0 & - \\
\hline - geslacht & 0 & 0 & 0 \\
\hline - ses & 0 & 0 & + \\
\hline - interne oriëntatie & 0 & 0 & 0 \\
\hline - religieuze oriëntatie & 0 & 0 & 0 \\
\hline - beïnvloedbaarheid verloop & 0 & 0 & 0 \\
\hline \multicolumn{4}{|c|}{$\begin{array}{l}0=\text { geen significant verband gevonden } \\
+=\text { significant verband gevonden in de verwachte richting } \\
\text { * = significant verband, geen specifieke verwachting geformuleerd. }\end{array}$} \\
\hline
\end{tabular}





\section{Continuïteit van de professionele zorgverlening}

In dit hoofdstuk worden de (gemiddelde) waarden van de indicatoren voor continuïteit van de professionele zorgverlening weergegeven. Per variabele is nagegaan of de waarden op de verschillende meetmomenten van elkaar afwijken. Op de eerste plaats zal een beschrijving worden gegeven van enkele structurele aspecten van het professionele zorgnetwerk (7.1). Ten tweede komt de taakovereenstemming tussen zorgverleners aan bod (7.2). Vervolgens zal worden ingegaan op tijds- en doelstellingsaspecten van continuiteit van de professionele zorgverlening (7.3, respectievelijk 7.4). In paragraaf 7.5 wordt aandacht besteed aan de onderlinge relatie tussen de indicatoren van continuïteit van de zorgverlening. De relatie tussen kenmerken van de ziekte en continuïteit van de zorgverlening wordt behandeld in paragraaf 7.6. Paragraaf 7.7 gaat over de onderlinge samenhang van de indicatoren van continuiteit van de zorgverlening en hun relatie met (het beloop van) kwaliteit van leven. In paragraaf $7.8 \mathrm{komt}$ het buffereffect van continuïteit van de professionele zorgverlening aan de orde.

\subsection{Structurele aspecten}

Structurele aspecten van het professionele netwerk hebben betrekking op de grootte van het netwerk en de onderlinge contacten van de professionele zorgverleners.

\subsubsection{Grootte van het professionele zorgnetwerk}

De grootte van het professionele netwerk wordt bepaald door het aantal professionele zorgverleners dat betrokken is bij de zorg voor de patiënt. In tabel 7.1 wordt het gemiddelde aantal betrokken zorgverleners bij de eerste en derde meting weergegeven. 
Tabel 7.1 Vergelijking van het aantal verschillende professionele zorgverleners op $\mathrm{t} 1$ en $\mathrm{t} 3$ meetmoment. t-test paren $(n=51)$.

t1

$\begin{array}{lllll}\text { gem } & \text { s.d } & \text { gem } & \text { s.d. } & p \\ 6.0 & 1.5 & 2.5 & 1.4 & \cdots \\ * \text { * } & <0.05 & & & \end{array}$

Bij de eerste meting hebben de patiënten in Noord-Limburg gemiddeld met zes verschillende zorgverleners te maken. Dit is te verklaren vanuit het gegeven dat alle patiënten zich bij de eerste meting aan het begin van het ziekteproces bevonden. Dit betreft een fase waarin diagnostiek, behandeling en ziekenhuisopnamen plaatsvinden. Hierdoor is het waarschijnlijk dat patiënten met veel verschillende zorgverleners te maken krijgen. Na verloop van tijd neemt het aantal zorgverleners, waarmee patiënten contact hebben, gemiddeld af.

In bijlage $\mathrm{F}$ worden de zorgverleners met wie de patiënten contact hebben alsmede de contactfrequenties vermeld. Zorgverleners waarmee de patiënten gedurende de hele meetperiode voornamelijk contact hebben, zijn de behandelend specialist, de huisarts en de radiotherapeut. De contactfrequentie met de verschillende zorgverleners neemt gemiddeld af in de loop der tijd. Opvallend is dat weinig patiënten zorg ontvangen van zorgverleners die gespecialiseerd zijn in psychosociale processen, zoals bijvoorbeeld een psycholoog of maatschappelijk werker.

\subsubsection{Onderlinge contacten}

De onderlinge contacten tussen betrokken zorgverleners vormen een indicator voor de mate van coördinatie van zorg (zie hoofdstuk 2). In het onderzoek hebben we ons beperkt tot bilaterale contacten. Om de onderlinge contacten te bepalen is het aantal betrokken zorgverleners vastgesteld. Vervolgens werden de onderlinge contacten tussen deze betrokken zorgverleners geteld. Als de patiënt géen contacten had met professionele zorgverleners of maar met één zorgverlener, zijn onderlinge contacten als niet van toepassing beschouwd. Contacten worden als relevant beschouwd als meer dan één professionele zorgverlener contact had met de patiënt.

Uit de tabel 7.2 blijkt dat de meeste onderlinge contacten tussen zorgverleners bij de eerste meting zijn gerapporteerd. Na verloop van tijd neemt het aantal onderlinge contacten af. 
Tabel 7.2 Onderlinge contacten tussen zorgverleners op het eerste en derde meetmoment, naar aantal casus $(n=51)$.

t1 13

Contacten niet van toepassing

Onderling contact relevant

Waarvan wél contact (minimaal 1)

Geen contact

Missing

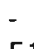

51

$44(86 \%$ van 51)

2
14

37

$13(34 \%$ van 37$)$

20

Op het eerste meetmoment blijken bij twee patiënten gén onderlinge contacten te bestaan. In 44 gevallen is er sprake van minimaal één contact. In totaal hebben bij de eerste meting, bij die 44 onderzoekseenheden, 82 contacten plaats gevonden tussen zorgverleners. Het merendeel daarvan bestaat uit contacten tussen huisartsen en specialisten, gevolgd door contacten tussen huisartsen en wijkverpleegkundigen c.q. specialisten en ziekenhuisverpleegkundigen (zie tabel 7.3).

Bij de derde meting neemt het aantal onderlinge contacten verder af. Bij veertien patiënten zijn onderlinge contacten niet van toepassing, bij twintig patiënten vinden geen onderlinge contacten plaats en bij dertien patiënten is er sprake van minimaal één contact tussen betrokken zorgverleners. In totaal vinden negentien verschillende contacten plaats, ook weer voor het grootste gedeelte tussen huisartsen en specialisten.

In tabel 7.3 wordt aangegeven welke zorgverleners met elkaar contacten hebben onderhouden. De meeste contacten die worden gerapporteerd zijn contacten tussen specialisten en huisartsen.

Tabel 7.3 Aantal 'paren' zorgverleners waarbij sprake is van onderling contact op t 1 en t3 ( $n=51)$.

\begin{tabular}{lrc}
\hline & $\mathrm{t} 1$ & $\mathrm{t} 3$ \\
\hline huisarts-specialist & 44 & 12 \\
huisarts-wijkverpleging & 10 & 3 \\
specialist-zhverpleging & 9 & - \\
specialist-radiotherapeut & 5 & - \\
huisarts-radiotherapeut & 4 & - \\
huisarts-zhverpleging & 4 & 4 \\
anderen & 6 & 19 \\
totaal & 82 & \\
\hline
\end{tabular}

Dat de meeste contacten plaatsvinden tussen huisartsen en specialisten is niet verwonderlijk. Zij zijn immers de disciplines met wie de meeste patiēnten met kanker het vaakst in aanraking komen. Daarnaast vormt het contact tussen huisarts en specialist een belangrijk middel om zorg over te dragen van de eerste naar de 
tweedelijns gezondheidszorg en vice versa. De onderlinge contacten tussen huisartsen en specialisten blijken voornamelijk plaats te vinden in het begin van het ziekteproces. Dit komt overeen met de resultaten van het onderzoek van Van der Wouden (1986) naar de samenwerking tussen huisartsen en specialisten. Uit dit onderzoek blijkt dat informatie voornamelijk wordt uitgewisseld bij afronding van de diagnose. In latere fasen van het ziekteproces, bijvoorbeeld bij nazorg, poliklinische behandeling en langdurige controle worden de onderlinge contacten minder (Van der Wouden, 1986).

Omdat de specialist en de huisarts belangrijke zorgverleners zijn in het zorgproces voor kankerpatiënten en omdat de onderlinge contacten tussen hen een verbinding vormen tussen eerste- en tweedelijns gezondheidszorg hebben we besloten om alleen onderlinge contacten tussen specialisten en huisartsen te gebruiken bij verdere analyses. Bij het bepalen van het aantal onderlinge contacten doet zich soms het probleem voor dat huisartsen en specialisten enkele malen wél onderlinge contacten rapporteren terwijl de patiënt in de onderzochte periode met één van beide geen contact had gehad. Besloten is om deze onderlinge contacten wel mee te rekenen. Er vinden op het eerste en derde meetmoment respectievelijk bij $44(86 \%)$ en 12 (24\%) eenheden onderlinge contacten plaats tussen specialist en huisarts.

Deze cijfers suggereren dat na de diagnose- en behandelingsfase weinig interprofessionele afstemming van zorg bestaat. Daarvoor zijn onderlinge contacten immers noodzakelijk.

\subsection{Het culturele aspect; taakovereenstemming}

Als tweede indicator voor continuïteit van zorg is gekozen voor de afstemming tussen professionele zorgverleners aangaande hun taakopvattingen. Met betrekking tot dit aspect beschikken we alleen over gegevens van de eerste meting. Ten aanzien van dertien taken gaven huisartsen, specialisten en verpleegkundigen hun mening over wie de primaire verantwoordelijkheid heeft bij die taken. Er zijn vijf antwoordmogelijkheden: de specialist, de huisarts, de wijkverpleegkundige, de ziekenhuisverpleegkundige en een andere zorgverlener. De antwoorden van wijk-en ziekenhuisverpleegkundigen zijn, gezien het geringe aantal, buiten beschouwing gelaten. Bij de volledige-responsgroep kunnen 39 paren 'huisarts - specialist' gevormd worden. Het aantal taken waarover, gemiddeld genomen, overeenstemming bestaat is laag, gemiddeld 7.1 (sd 1.9, min. 3, max 11). Nagegaan is hoe de score zou zijn als we uitgaan van de toevalskans. De toevalkans op overeenstemming is berekend aan de hand van randtotalen van de kruistabellen waarin de scores van huisarts en specialist werden weergegeven. De score op grond van het toeval zou 6.9 zijn. Dit betekent dat de gemiddelde score (7.1) nauwelijks hoger is dan op grond van het toeval verwacht zou mogen worden.

Binnen de paren komt het vaak voor dat zorgverleners zichzelf primair verantwoordelijk achten voor de genoemde taken. De huisartsen en specialisten zijn vaak niet in staat om én zorgverlener als primair verantwoordelijke aan te wijzen. Soms worden twee of zelfs drie zorgverleners als primair verantwoordelijk aangeduid. Dit gegeven vormt een aanwijzing dat taakafbakening een probleem vormt. Besloten werd om bij het berekenen van de overeenstemming 'soepel' te zijn en ook als er 
twee zorgverleners zijn genoemd, de overeenstemming te bekijken. Als bijvoorbeeld een huisarts de specialist ến zichzelf als verantwoordelijke noemt en de specialist alleen zichzelf, dan wordt dit wel als overeenstemming gescoord. Het aantal taken waarover overeenstemming bestaat is dus enigszins positief vertekend.

Het aantal taken waarover overeenstemming bestaat, wordt gebruikt als variabele in de verdere analyses, die in de volgende hoofdstukken aan bod komen.

$\mathrm{Er}$ is vervolgens nagegaan over welke taken wel en over welke taken geen overeenstemming bestaat.

Bij meer dan $75 \%$ van de 39 paren 'huisartsen en specialisten' blijkt overeenstemming te bestaan over de primaire verantwoordelijkheid bij de volgende taken:

- Het begeleiden van de patiënt tijdens opname.

(32 $\times$ overeenstemming : $12 \times \mathrm{sp}, 17 \times \mathrm{sp} / \mathrm{zhv}, 2 \times \mathrm{ha} / \mathrm{sp}, 1 \times \mathrm{zhv}$ ).

- Het verstrekken van medische informatie over de ziekte en de behandelingsmethoden.

(31 $\times$ overeenstemming: $4 \times$ sp, $27 \times$ ha/sp).

- Het begeleiden van gezinsleden ten aanzien van eventuele problemen ten gevolge van de ziekte van de patiënt.

(31 x overeenstemming : $25 \times$ ha, $3 \times$ ha/sp, $3 \times$ ha/wijk).

- Het bewaken van de totale zorgverlening en zonodig initiatief nemen om lacunes in de zorg op te vullen.

(30 x overeenstemming : $23 \times$ ha, 5 ha/wijk, 2 ha/sp).

$\mathrm{sp}=$ specialist, $\mathrm{ha}=$ huisarts, $\mathrm{zhv}=$ ziekenhuisverpleegkundige, wijk $=$ wijkverpleegkundige

Over het begeleiden van gezinsleden en het bewaken van het totale zorgpruces bestaat al met al nog de meeste duidelijkheid; dat is volgens beide partijen de taak van de huisarts. Bij het informeren over de ziekte en de behandeling, alsmede de begeleiding tijdens opname, speelt in ieder geval de specialist een belangrijke rol, in samenwerking met de huisarts en de ziekenhuisverpleegkundige.

Dit komt overeen met de resultaten van het onderzoek van Engelsman e.a.(1989) waarin de taakopvattingen van zorgverleners, bij patiënten die chemotherapie kregen, zijn bestudeerd. Huisartsen en specialisten zijn het in dat betreffende onderzoek er over eens dat de taken: het informeren naar de thuissituatie, het begeleiden van de gezinsleden en het regelen van de zorgverlening, tot die van de huisarts behoren. Het informeren over de behandeling en bijwerkingen daarvan, zijn taken die bij de specialist horen.

In ons onderzoek blijkt er ook een aantal taken te zijn waarover de meningen zeer verdeeld zijn. Bij slechts $30 \%$ of minder van de paren blijkt overeenstemming te bestaan over de taken:

- Het geven van voorlichting over en het toelichten van leefregels .

(10 x overeenstemming) 
- Het begeleiden bij ziekteverwerking en acceptatieproblemen.

(10 x overeenstemming)

- Het voorlichting geven uver het gebruik van hulpmiddelen, prothese.

$(6 \times$ overeenstemming)

Over slechts een beperkt aantal taken bestaat duidelijkheid met betrekking tot de primaire verantwoordelijkheid: het begeleiden van gezinsleden en het bewaken van de totale zorgverlening. Over het geven van voorlichting over hulpmiddelen en leefregels en de begeleiding bij ziekteverwerking blijkt weinig overeenstemming te bestaan. Bij deze, niet onbelangrijke onderdelen van de zorgverlening, is het dus blijkbaar niet duidelijk wie primair verantwoordelijk is.

\subsection{Het tijdsaspect}

Voor het aspect afstemming in de tijd zijn twee indicatoren gebruikt: het al dan niet geholpen worden door dezelfde specialist op de polikliniek en het ontvangen van zorg na het ontslag uit het ziekenhuis in de vorm van huisbezoeken van huisarts en/of wijkverpleegkundigen.

\subsubsection{Dezelfde specialist}

De meerderheid van de patiënten blijkt steeds door dezelfde specialist behandeld of gecontroleerd te worden. Op het eerste meetmoment heeft $81 \%$ te maken met een en dezelfde specialist, op het derde meetmoment $77 \%$ van de patiënten. Om én maat te creëren voor continuïteit in de zorg van de specialist is bepaald hoeveel patiënten gedurende de hele onderzoeksperiode contact hadden met én en dezelfde specialist. Dit blijkt bij 30 (59\%) patiënten het geval te zijn.

\subsubsection{Bezoek na ontslag}

Achtenveertig ( $94 \%$ ) patiënten zijn in het ziekenhuis opgenomen geweest in verband met kanker. Bij $42(88 \%)$ van deze patiënten is na het ontslag uit het ziekenhuis een professionele zorgverlener thuis geweest. Bij 32 patiënten hebben de huisarts en/of de wijkverpleegkundige de patiënt binnen én week na ontslag thuis bezocht.

Na verloop van tijd verminderen gemiddeld de contacten met de gezondheidswerkers in de eerste lijn. Bij de derde meting heeft nog maar $70 \%$ van de respondenten contact met de huisarts en $12 \%$ met een wijkverpleegkundige. De meeste van de contacten met de huisarts ontstaan op initiatief van de patiënt zelf.

Enkele huisartsen vertelden dat zij een min of meer afwachtende houding aannemen en zichzelf pas weer een actieve rol toebedelen als de patiënt in een terminale fase van het ziekteproces verkeert. Sommige huisartsen noemen het feit dat de patiënt particulier verzekerd is en het 'niet afhankelijk willen maken' als redenen om niet uit zichzelf bij de patiënt op bezoek te gaan. De meeste huisartsen hebben met de patiënt de afspraak gemaakt dat de patiënt zelf zal bellen als er iets is. 


\subsection{Het doelstellingsaspect}

Om inzicht te krijgen in de mate waarin de zorg is afgesternd op de zorgbehoeften van de patiënt zijn twee indicatoren gebruikt: tevredenheid met de zorgverlening en de overeenstemming tussen patiënten en zorgverleners met betrekking tot de zorgbehoeften.

\subsubsection{Tevredenheid met de zorgverlening}

Als indicatoren voor tevredenheid zijn behalve een globale score (tevredenheid over de totale zorgverlening) ook specifieke vragen over de huisarts en specialist gebruikt (zie hoofdstuk 3). Patiënten blijken gemiddeld genomen (zeer) tevreden te zijn over de zorgverlening. Toch zijn, bij een open vraag ten aanzien van onprettige ervaringen met de gezondheidszorg, regelmatig klachten geuit. Het vaakst zijn genoemd: gebrek aan aandacht en steun (18 keer), de diagnosegesprekken (11 keer), nalatigheden en fouten ( 10 keer), een onbehoorlijke bejegening ( 9 keer), gebrek aan informatie $(8 \mathrm{keer})$ en lange wachttijden $(8 \mathrm{keer})$. In tabel 7.4 zijn de scores met betrekking tot de globale tevredenheid en de tevredenheid over huisarts en specialist weergegeven.

\begin{tabular}{lllllll}
\hline & gem & sd & gem & sd & p \\
Globale tevredenheid $(n=50)$ & 4.3 & .58 & 4.2 & .50 & n.s \\
Tevredenheid Specialist $(n=51)$ & 4.1 & .80 & 3.9 & .74 & $\ldots$ \\
Tevredenheid Huisarts $(n=51)$ & 4.3 & .70 & 3.9 & .66 & $\ldots$ \\
$* \mathrm{p}<0.05$ & & & & & & \\
\hline
\end{tabular}

De meeste patiënten zijn, globaal bekeken, tevreden over de zorg die ze hebben ontvangen. Er treedt, in de loop van de tijd, weinig verandering op in de globale tevredenheid over de zorg.

De patiënten blijken in het algemeen tevreden te zijn over hun huisarts en specialist. De tevredenheid over de specialist $(\mathrm{t} 1-\mathrm{t} 3, \mathrm{t}=1.98, \mathrm{p}<0.05)$ en de huisarts nemen echter significant af tussen de eerste en de derde meting ( $t 1-\mathrm{t} 3, \mathrm{t}=3.16, \mathrm{p}<$ 0.05 ). Uit de interviews met de patiënten komt regelmatig naar voren dat patiënten vinden dat de specialist te weinig informatie geeft over de stand van zaken en dat hij tijdens de controles op de polikliniek te weinig tijd heeft voor vragen. 
Contacten met de huisarts worden in het algemeen minder frequent na verloop van tijd. Wellicht ligt hierin de verklaring voor de afnemende tevredenheid over de huisarts.

Tijdens de interviews is regelmatig naar voren gekomen dat patiënten het erg waarderen als de huisarts zomaar uit zichzelf langs komt voor een huisbezoek. Sommigen vinden het jammer dat de huisarts weinig belangstelling toont. Zo vertelde een patiënt met longkanker: "ik heb nog nooit iemand gezien die iets aan nazorg deed. Ik zou nog zoveel vragen willen stellen, maar aan wie ? Ook mijn vrouw wist niet wat we wel of niet moesten doen, het was een zware tijd. Als ik op de hele periode terugkijk dan hadden we meer begeleiding nodig, nu hebben we alles zelf moeten uitzoeken. Ik had meer interesse verwacht van de huisarts, die is nog nooit hier geweest".

Uiteraard zijn er ook veel patiënten waarbij er wel sprake is van begeleiding door de huisarts en is het algemene oordeel van de patiënt positief.

\subsubsection{Overeenstemming over zorgbehoeften}

De tweede indicator voor 'doelstellings-afstemming' is de mate van overeenstemming tussen patiënten en zorgverleners over de zorgbehoefte.

De volgende zorgbehoeften zijn beoordeeld door patiënten en zorgverleners: activiteiten van het dagelijks leven, huishoudelijke activiteiten, medicijngebruik, lichamelijke oefeningen naar aanleiding van de aandoening/behandeling en verwerken van de ziekte. Er zijn paren gevormd van huisartsen en patiënten, centrale verzorger en patiënten en specialisten en patiënten. De mate van overeenstemming is berekend met Cohen's Kappa. In bijlage $G$ worden de Kappa en de maximale Kappa op grond van de randtotalen weergegeven alsmede het aantal keren dat er overeenstemming bestaat en het aantal keren dat de zorgverlener de behoefte over- c.q. onderschat. De coëfficiënt Kappa is een maat voor de afstemming na correctie voor de toevalsovereenstemming. Een Kappawaarde van 0 duidt op toevalsovereenstemming, een waarde van 1 duidt op perfecte overeenstemming, -1 duidt op een systematisch gebrek aan overeenstemming.

Zowel bij de eerste als bij de derde meting is de overeenstemming tussen centrale verzorgers en patiënten met betrekking tot activiteiten van het dagelijks leven (ADL) en huishoudelijke activiteiten (HDL) groter dan de overeenstemming tussen (huis)artsen en patiënten. Met name bij de huishoudelijke activiteiten schatten artsen de zorgbehoefte vaak lager in dan de patiënten zelf. Mogelijkerwijs zijn verschillen in de mate van overeenstemming tussen artsen en centrale verzorgers deels te verklaren uit kennis van de centrale verzorger over de thuissituatie van de patiënt. $\mathrm{Bij}$ de eerste meting is de mate van overeenstemming ten aanzien van medicijngebruik bij centrale verzorgers en huisartsen ongeveer even groot. De overeenstemming tussen specialisten en patiënten berust op toeval. Op het derde meetmoment is er, aangaande deze zorgbehoefte, meer overeenstemming tussen centrale verzorgers en patiënten. Met betrekking tot behoefte aan zorg bij het doen van oefeningen is de overeenstemming matig, op het eerste meetmoment. Op het derde meetmoment is er redelijk wat overeenstemming, met name tussen huisartsen en patiënten. 
Ten aanzien van de behoefte aan zorg bij ziekteverwerking zien we een opmerkelijk verschijnsel. Op tl schatten met name de centrale verzorgers en de huisartsen de behoefte aan zorg in deze vaak hoger in dan de patiënten zelf. Bij de specialisten moet worden opgemerkt dat maar liefst 16 keer 'ik weet het niet' is geantwoord. Op het derde meetmoment is er meer overeenstemming tussen huisartsen en patiënten. Centrale verzorgers blijven de zorgbehoefte ten aanzien van ziekteverwerking echter hoger inschatten dan de patiënten zelf.

Enkele mogelijke verklaringen voor het hoger inschatten van deze behoefte aan zorg bij ziekteverwerking door professionele en niet-professionele zorgverleners zijn:

- Op het hebben van emotionele problemen rust een taboe. Wellicht vinden patiënten het moeilijk om over deze problemen te praten met een 'vreemde' interviewer. Er kan dus sprake van onderrapportage zijn wat deze zorgbehoefte betreft.

- De patiënten zijn in de eerste fase van het ziekteproces geïnterviewd. Een afweermechanisme dat vaak gebruikt wordt in deze fase is ontkenning. Het kan ook zijn dat patiënten in deze fase nog niet toe zijn aan de psychische verwerking van hun ziekte en veelal nog met de lichamelijke gevolgen en de behandeling bezig zijn.

- Er kan ook sprake zijn van een soort fixatie aan normen van professionele zorgverleners of proto-professionalisering van centrale verzorgers: "iemand met kanker moet wel psychische problemen hebben". Deze norm hoeft helemaal niet aan te sluiten bij de beleving van de patiënt.

- Patiënten zien hulp bij ziekteverwerking wellicht als iets dat alleen door professionals gedaan wordt bijvoorbeeld door het RIAGG. Een goed gesprek met de buurvrouw wordt door hen mogelijk niet als 'hulp bij ziekteverwerking' beschouwd.

De Kappawaarden zijn, vooral waar het de paren arts-patiënt betreft, aan de lage kant. Dat wil zeggen dat de overeenstemming die gevonden is voornamelijk op toeval berust. Bovendien wordt regelmatig, met name door de specialisten, aangegeven dat men niet weet of de patiënt zorgbehoeften heeft. Deze gegevens duiden er op dat de zorgverlening niet altijd zal zijn afgestemd op de behoeften van de patiënt.

Om één maat voor de overeenstemming te krijgen zijn de zorgbehoeften waarover overeenstemming bestaat tussen de zorgverleners en de patiënt bij elkaar opgeteld. Er zijn, indien mogelijk, steeds twee paren gevormd : 'patiënt-centrale verzorger' en 'patiënt-huisarts'. De scores van de specialisten zijn buiten beschouwing gelaten vanwege een groot aantal ontbrekende gegevens. De theoretische range varieert van 0 (over geen enkele zorgbehoefte overeenstemming) tot 5 (over alle zorgbehoeften overeenstemming). De resultaten worden in tabel 7.5 weergegeven. In de tabel zijn alleen de scores vermeld van zorgverleners die zowel op het eerste als op het derde meetmoment vragen over de zorgbehoeften hebben beantwoord. 
Tabel 7.5 Vergelijking aantal zorgbehoeften waarover overeenstemming bestaat (tussen patiëriten en centrale verzorgers c.q. huisartsen) op $\mathrm{t} 1$ en $\mathrm{t} 3$. (variatiebreedte 1-5). t-test paren $(n=40)$.

\begin{tabular}{|c|c|c|c|c|c|c|}
\hline & & $t 1$ & & t3 & & p \\
\hline & & gem & s.d & gem & s.d & \\
\hline centrale verzorger & $(n=39)$ & 4.3 & .87 & 4.3 & .89 & n.s \\
\hline huisarts & $(n=40)$ & 3.9 & .83 & 4.0 & 1.1 & n.s \\
\hline
\end{tabular}

Het gemiddelde (totaal) aantal zorgbehoeften waarover overeenstemming bestaat is hoog. De huisartsen scoren op het aantal zorgbehoeften waarover overeenstemming bestaat gemiddeld lager dan de centrale verzorgers, maar de verschillen zijn niet significant. Ook treden er geen significante veranderingen in de tijd op.

\subsection{Samenhang tussen de indicatoren}

Om tot reductie van het aantal variabelen te komen is nagegaan in hoeverre de verschillende indicatoren voor continuïteit van de zorgverlening met elkaar samenhangen. Wat het meeste opvalt in de correlatiematrices (zie bijlage $\mathrm{H}$ ) is dat de drie maten voor tevredenheid steeds met elkaar samenhangen evenals de maten voor overeenstemming over de zorgbehoeften. Besloten is om de drie maten voor tevredenheid samen te voegen, door ze bij elkaar op te tellen. Als maat voor overeenstemming met betrekking tot zorgbehoeften is gekozen voor de mate van overeenstemming tussen patiënt en huisarts. Uit de correlatiematrix van het gereduceerd aantal variabelen (zie bijlage I) blijkt dat de verschillende indicatoren voor continuïteit van de zorgverlening weinig onderlinge samenhang vertonen. Op het eerste meetmoment is een significante positieve samenhang gevonden $(r=.27)$ tussen de mate waarin men te maken heeft met steeds dezelfde specialist en de tevredenheid over de zorgverlening. Een negatief verband is gevonden tussen het ontvangen van bezoek na ontslag en het behandeld worden door dezelfde specialist $(r=-.23)$. Op het derde meetmoment vinden we een negatieve samenhang tussen de mate waarin er sprake is van zorgverlening door één en dezelfde specialist en het aantal zorgverleners $(\mathrm{r}=-.32)$. Positief is de relatie tussen de overeenstemming over de zorgbehoeften en de tevredenheid over de zorg $(r=.25)$.

\subsection{Samenhang tussen ziektekenmerken en continuïteit van de professionele zorgverlening}

In de inleiding van dit proefschrift hebben we aangegeven dat we een samenhang verwachten tussen de ernst van de ziekte en de mate van continuïteit van de zorgverlening. In welke richting die samenhang gaat, is nog niet duidelijk. Verwacht wordt dat naarmate patiënten ernstiger ziek zijn, dat wil zeggen een slechte overlevingsprognose en metastasen hebben, er meer zorgactiviteiten zullen plaats 
vinden en er meer professionele zorgverleners bij de zorg betrokken zijn. Het zal dan waarschijnlijk meer inspanning kosten om afstemming te bewerkstelligen. In ons onderzoek is getracht de relatie tussen kenmerken van de ziekte en de mate van continuïteit te onderzoeken. In tabel 7.6 wordt de samenhang tussen de ernst van de ziekte respectievelijk ziekteduur (tijd sinds het stellen van de diagnose) en de indicatoren voor continuiteit van zorg weergegeven.

Tabel 7.6

Samenhang tussen ernst c.q. ziekteduur en indicatoren voor continuïteit van zorg op $\mathrm{t} 1$ en $\mathrm{t} 3$. Pearson correlaties $(n=51)$

$\mathbf{t 1}$

aantal prof.zorgverleners

contact huisarts-specialist

overeenstemming taken

dezelfde specialist

bezoek na ontslag

tevredenheid over zorg

overeenstemming zorgbehoeften ha-pat

t3

aantal prof.zorgverleners

contact huisarts-specialist

tevredenheid over zorg

overeenstemming zorgbehoeften ha-pat

$\begin{array}{ll}\text { ernst t1 } & \text { ziekteduur } t 1 \\ -.11 & -.39 * \\ -.17 & -.19 \\ .08 & .04 \\ -.27^{*} & -.02 \\ .17 & -.23^{*} \\ -.32^{*} & -.03 \\ .06 & .15 \\ & \\ \text { ernst } t 1 & \text { ziekteduur } t 1 \\ .12 & -.02 \\ -.05 & .12 \\ -.32 * * & .03 \\ .11 & -.25 * \\ & \end{array}$

Zowel bij de eerste als bij de derde meting blijkt dat naarmate patiënten ernstiger ziek zijn, ze minder tevreden zijn over de zorg die ze ontvangen. Een mogelijke verklaring is dat naarmate patiënten ernstiger ziek zijn ze meer het gevoel hebben dat er geen behandeling meer mogelijk is. Zij hebben wellicht minder hoop dat de gezondheidszorg nog iets voor hen kan betekenen.

$\mathrm{Er}$ is geen samenhang gevonden tussen de 'objectieve' ernst van de ziekte en het aantal zorgverleners, het ontvangen van nazorg na ontslag uit het ziekenhuis, de contacten tussen huisartsen en specialisten, de taakovereenstemming tussen huisartsen en specialisten en overeenstemming tussen huisartsen en patiënten ten aanzien van de zorgbehoeften. Wel blijken ernstig zieke patiënten vaker met meer dan éen specialisten te maken hebben. Ernstig zieke patiēnten zijn wellicht op zoek naar een zogenaamde 'laatste strohalm'. Naarmate het probleem complexer en moeilijker te behandelen is worden meer specialisten geconsulteerd.

Bij de eerste meting is een samenhang gevonden tussen ziekteduur en het aantal contacten met professionele zorgverleners. Naarmate de diagnose langer geleden is gesteld, hebben patiënten met minder professionele zorgverleners te maken. Dit komt overeen met wat in paragraaf 7.1 al werd geconcludeerd, namelijk dat het aantal contacten met zorgverleners gemiddeld afneemt na verloop van tijd. Bovendien blijkt dat naarmate de diagnose langer geleden is gesteld, er minder bezoek van huisarts 
en/of wijkverpleegkundige na ontslag plaatsvindt. Op het derde meetmoment blijkt er een relatie te bestaan tussen het aantal zorgbehoeften waarover overeenstemming bestaat (tussen huisarts en patiënt) en de ziekteduur. Naarmate de diagnose langer geleden is gesteld, neemt deze overeenstemming af. Een verklaring kan zijn dat huisartsen na verloop van tijd minder contacten hebben met de patiënt, waardoor ze de zorgbehoeften minder goed kunnen inschatten. Tussen de ziekteduur en de andere indicatoren voor continuïteit van de zorgverlening zijn geen relaties gevonden.

Met behulp van één-weg variantieanalyses en chi-kwadraat toetsen is nagegaan in hoeverre de behandeling en de diagnose van invloed zijn op continuïteit van zorg. De verschillende behandelingen die de patiënten hebben ondergaan en de diagnoses, blijken niet van invloed te zijn op de indicatoren voor continuiteit van zorg. Dit is mogelijk te verklaren door de heterogeniteit van de groep en de kleine aantallen. Uit deze gegevens kunnen we concluderen dat ernstig ziek zijn, volgens objectieve maatstaven, niet automatisch leidt tot meer afstemming van zorg. Ook ziekteduur, diagnose en de behandeling blijken nauwelijks van invloed te zijn op de mate van continuïteit.

\subsection{Samenhang tussen de indicatoren van continuïteit van de professionele zorgverlening en kwaliteit van leven}

Tenslotte is nagegaan in hoeverre de verschillende indicatoren van continuiiteit van de zorgverlening samenhang vertonen met de maat voor kwaliteit van leven op het cerste en derde meetmoment. In tabel 7.7 staan de correlaties tussen de indicatoren voor continuïteit van de zorgverlening en kwaliteit van leven.

Uit deze correlatiematrix kan worden geconcludeerd dat (met name bij de derde meting) samenhang bestaat tussen het aantal professionele zorgverleners en kwaliteit van leven: naarmate patiënten een slechtere kwaliteit van leven rapporteren op het derde meetmoment, hebben ze met meer verschillende professionele zorgverleners te maken. Het contact met de huisarts op het derde meetmoment hangt negatief samen met de kwaliteit van leven $(r=-.32, p<0.05)$. Ook het contact met de wijkverpleegkundige hangt samen met een relatief slechte kwaliteit van leven op het derde meetmoment $(r=-.50, p<0.05)$. Contacten tussen huisarts en specialist, het steeds geholpen worden door dezelfde specialist en bezoek van een zorgverlener op het eerste meetmoment na ontslag uit het ziekenhuis zijn factoren die blijkbaar niet samenhangen met kwaliteit van leven. Wel wordt er een negatieve samenhang gevonden tussen de mate waarin er sprake is van overeenstemming over taken tussen huisarts en specialist en de kwaliteit van leven. Bij mensen met een relatief slechte kwaliteit van leven is er sprake van meer overeenstemming over de verantwoordelijkheid ten aanzien van de taken.

Met name bij de eerste meting is een positieve samenhang gevonden tussen tevredenheid over de zorg en kwaliteit van leven; hoe beter de kwaliteit van leven, hoe groter de tevredenheid met de zorgverlening. Wat de overeenstemming over de zorgbehoeften betreft, zien we een consistent positief verband met kwaliteit van leven. Hoe meer overeenstemming tussen huisarts en patiënt over zorgbehoeften, des te beter de kwaliteit van leven van de patiënt. De correlaties zijn echter niet significant (p-waarden zijn 0.12 , respectievelijk 0.11 ). 


\begin{tabular}{lcc}
\hline & kwaliteit leven $\mathrm{t} 1$ & kwaliteit leven $\mathrm{t} 3$ \\
aantal zorgverleners $\mathrm{t} 1, \mathrm{t} 3$ & .10 & $-.36 * *$ \\
contact huisarts-specialist $\mathrm{t} 1, \mathrm{t} 3$ & .02 & .09 \\
overeenstemming taken $\mathrm{t} 1$ & $-29^{*}$ & $-.53^{* *}$ \\
dezelfde specialist & .09 & .03 \\
bezoek na ontslag & .00 & $\mathrm{n} . \mathrm{v} \cdot \mathrm{t}$ \\
tevredenheid over zorg $\mathrm{t} 1, \mathrm{t} 3$ & $.29^{* *}$ & .00 \\
overeenstemming zorgbehoeften $\mathrm{t} 1, \mathrm{t} 3$ & .16 & .19 \\
& & \\
$* \mathrm{p}<0.10, * \mathrm{p}<0.05$ & & \\
\end{tabular}

Naast deze transversale analyses zijn ook longitudinale analyses gedaan waarbij het beloop van kwaliteit van leven als afhankelijke variabele is gebruikt. Zoals in hoofdstuk 5 is beschreven kunnen twee groepen worden gevormd. De eerste groep bestaat uit 26 patiënten die in de loop van de onderzoeksperiode achteruit zijn gegaan of gelijk zijn gebleven in kwaliteit van leven. De tweede groep ornvat 25 patiënten die vooruit zijn gegaan. Deze twee groepen zijn met elkaar vergeleken met betrekking tot de indicatoren voor continuïteit van de zorgverlening.

Uit de analyses van de relatie tussen de indicatoren voor continuïteit van de professionele zorgverlening en het beloop van kwaliteit van leven kan worden geconcludeerd dat er verschillen zijn ten aanzien van het aantal professionele zorgverleners met wie de patiënt te maken heeft, de taakafbakening en de tevredenheid over de zorgverlening. Deze resultaten staan in tabel 7.8 beschreven. De groep die na verloop van tijd achteruit gaat/gelijk blijft in kwaliteit van leven, heeft op de eerste meting met significant meer professionele zorgverleners te maken dan de patiënten die vooruit gaan na verloop van tijd. Bij de derde meting zijn er geen significante verschillen meer wat het aantal zorgverleners betreft.

Bij de patiënten die achteruit zijn gegaan in kwaliteit van leven is er over meer taken overeenstemming tussen huisarts en specialist dan bij patiënten die vooruit zijn gegaan. Op het derde meetmoment wordt er een significant verschil gevonden met betrekking tot de tevredenheid over de zorgverlening. Patiënten die achteruit zijn gegaan of gelijk zijn blijven scoren zijn tevredener over de zorg, op het derde meetmoment, dan patiënten die vooruit zijn gegaan in kwaliteit van leven. 


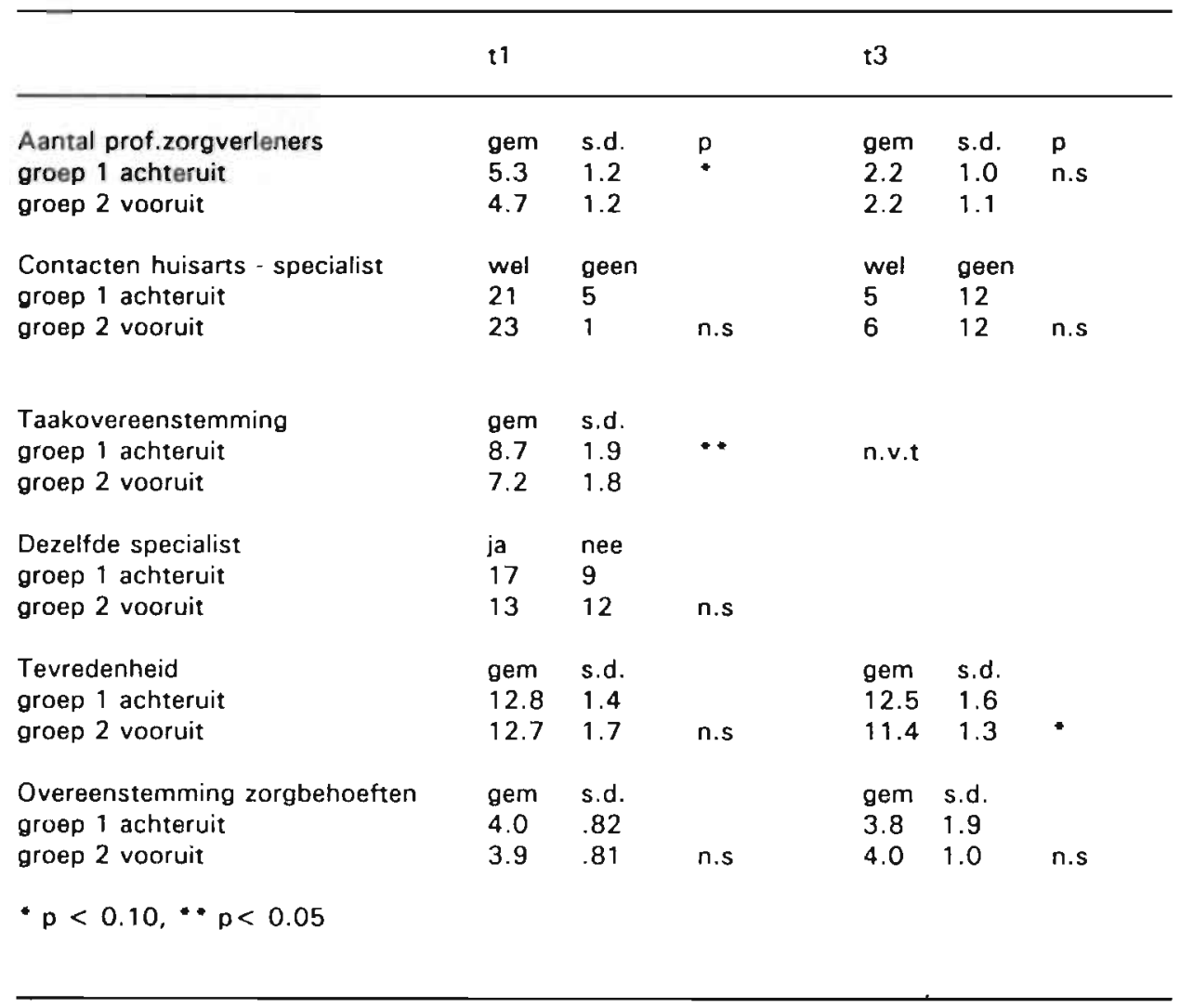

\subsection{Buffereffect van continuïteit van zorg}

In hoofdstuk 1 is beschreven dat continuïteit van de zorgverlening mogelijk een buffereffect heeft. Dat wil zeggen dat de mate van afstemming van de zorg een versterkende dan wel verzachtende invloed kan hebben op de effecten van ziekte en behandeling op kwaliteit van leven (pijl 4 in ons onderzoeksmodel). Met andere woorden we willen nagaan in hoeverre de mate van continuïteit van zorg een modererende invloed uitoefent op de relatie tussen ziekte en kwaliteit van leven. Het probleem hierbij is dat continuiteit van de professionele zorgverlening gemeten is met behulp van een aantal indicatoren die onderling weinig samenhang vertonen en waarvan slechts enkele samenhang vertonen met kwaliteit van leven. Besloten is om alleen bij de eerste meting een index te maken uit drie variabelen die samenhangen met kwaliteit van leven: taakovereenstemming, overeenstemming over de zorgbehoeften en tevredenheid over de zorg. Het aantal zorgverleners is niet opgenomen in de index omdat deze maat alleen iets zegt over de omvang van de zorgverlening en niet over de afstemming. 
De gebruikte maten zijn steeds gedichotomiseerd. Daarbij is de mediaan als criterium gebruikt. Ontbrekende waarden zijn gecodeerd als positief in die zin dat er dan wél sprake is van continuïteit van zorg. De scores op de drie variabelen zijn vervolgens opgeteld tot én score voor continuïteit van zorg. Op deze manier hebben we kunnen nagaan bij welke patiënten relatief weinig continuïteit van de zorgverlening bestaat en bij welke relatief veel. Bij de eerste meting scoren vier patiënten op geen enkele indicator positief, twaalf op één indicator, negentien patiënten scoren op twee indicatoren en zestien personen op alle drie de indicatoren positief. We onderscheiden een groep met een score lager dan twee op de index $(n=16)$ en een groep die twee of drie scoort $(n=35)$.

Vervolgens is voor beide groepen afzonderlijk de Pearson correlatic tussen ernst van de ziekte en kwaliteit van leven berekend. Deze blijkt voor de groep met een lage score op de continuïteit van zorgverlening-index $.56(p=0.02)$ te bedragen en voor de groep met een relatief hogere score $.26(p=0.14)$. Met de $z$-toets voor twee correlatiecoëfficiënten (Kleinbaum, 1988) is nagegaan of deze correlatiescoëfficiënten significant van elkaar verschillen. Dit blijkt niet het geval te zijn $(U=1.11, n . s)$. Op deze wijze kon dus een buffereffect van continuïteit van de zorgverlening niet aangetoond worden.

\subsection{Samenvatting en conclusies}

Over continuïteit van de professionele zorgverlening kan het volgende worden geconcludeerd. Patiënten hebben vooral in het begin van de ziekteperiode, maar ook in latere fasen, te maken met veel verschillende zorgverleners. Bij de eerste meting gemiddeld met zes verschillende beroepskrachten. Het aantal zorgverleners met wie patiënten contacten onderhouden nemen, zoals verwacht, af in de loop van het onderzochte jaar. Dat geldt ook voor de frequentie van de contacten met deze zorgverleners. Zeker als het om veel contacten gaat, vormen onderlinge contacten tussen zorgverleners een voorwaarde voor de afstemming van de zorgverlening. Die onderlinge contacten blijken voornamelijk plaats te vinden tussen huisartsen en specialisten, tijdens de periode waarin diagnostiek en behandeling plaatsvinden. $\mathrm{Na}$ verloop van tijd neemt het aantal onderlinge contacten drastisch af. Het ontbreken van deze onderlinge contacten kan een knelpunt in de continuiteit van de zorgverlening worden genoemd.

Een ander knelpunt wordt gevormd door de taakafbakening. Tussen huisartsen en specialisten blijkt weinig overeenstemming te bestaan. Over twee taken zijn zij het duidelijk met elkaar eens: het begeleiden van gezinsleden en het bewaken van de totale zorgverlening zijn taken voor de huisarts. Over een aantal andere wezenlijke taken in de zorgverlening, zoals het begeleiden bij ziekteverwerking en het informeren over hulpmiddelen en leefregels, bestaat echter weinig overeenstemming.

Wat het tijdsaspect betreft kan geconcludeerd worden dat het merendeel van de patiënten te maken heeft met één specialist op de polikliniek en dat de meerderheid van de patiënten is bezocht door de huisarts en/of wijkverpleegkundige na ontslag uit het ziekenhuis. Contacten met huisartsen en wijkverpleegkundigen nemen sterk af na verloop van tijd. 
Patiënten blijken in het algemeen tevreden te zijn over de zorg die zij hebben ontvangen. Tijdens de onderzoeksperiode is echter een significante afname van de tevredenheid over de specialist en over de huisarts waargenomen.

Wat de overeenstemming over de zorgbehoeften van de patiënt betreft, vinden we de meeste discrepantie bij de behoefte aan zorg bij huishoudelijke activiteiten en de behoefte aan zorg bij het verwerken van de ziekte. De behoefte aan huishoudelijke zorg wordt door artsen vaak lager ingeschat dan door de patiënten zelf. Bij ziekteverwerking schatten de zorgverleners, met name centrale verzorgers en huisartsen, de zorgbehoefte hoger in dan de patiënten zelf.

Er blijkt geen duidelijke samenhang te bestaan tussen objectieve kenmerken van de ziekte c.q. behandeling en de indicatoren voor continuiteit van zorg. De ernst van de ziekte, geïndiceerd door de overlevingsprognose en het stadium, leidt in ieder geval niet tot meer continuiteit van de zorg. Er is wel een samenhang gevonden tussen de ernst van de ziekte en de tevredenheid over de zorgverlening. Patiënten die ernstiger ziek zijn, zijn zowel op het eerste als op het derde meetmoment ontevredener over de zorgverlening dan patiënten die minder ernstig ziek zijn. Ook blijken ernstig zieke patiënten met meer specialisten te maken te hebben. Naarmate het tijdsverloop sinds de diagnose langer is, zijn er minder professionele zorgverleners bij de zorg betrokken en is er minder overeenstemming over de zorgbehoeften van de patiënt.

De relaties tussen de indicatoren voor continuïteit van de zorgverlening en kwaliteit van leven kunnen worden samengevat in tabel 7.9.

Er blijkt een verband te bestaan tussen kwaliteit van leven en het aantal professionele zorgverleners: hoe slechter de kwaliteit van leven, hoe meer zorgverleners op het eerste meetmoment bij de zorg betrokken zijn. Ook patiënten met een negatief beloop in kwaliteit van leven hebben bij de eerste meting te maken met meer zorgverleners. Het lijkt er op dat niet zozeer de objectieve ernst (prognose en stadium) maar de subjectief ervaren mate van disfunctioneren, klachten en globaal welbevinden leiden tot meer gebruik van professionele zorg.

Een andere factor die van belang blijkt te zijn is de takovereenstemming. We vinden zowel bij de transversale als de longitudinale analyse een verband dat tegengesteld is aan onze verwachting, namelijk hoe slechter de kwaliteit van leven hoe beter de taakovereenstemming is. Blijkbaar hangt een problematische situatie niet alleen samen meer zorgverlening, maar ook met een betere taakovereenstemming.

Daarnaast is een verband gevonden tussen tevredenheid over de zorgverlening en kwaliteit van leven. Bij de transversale analyses blijkt op de eerste meting een grotere tevredenheid samen te gaan met een betere kwaliteit van leven en vice versa. $\mathrm{Bij}$ bestudering van de relatie met het beloop van kwaliteit van leven is gebleken dat juist patiënten met een negatief beloop (een verslechterde kwaliteit van leven) tevredener zijn op het derde meetmoment.

Bestudering van de relatie tussen de indicatoren voor continuïteit van de zorgverlening en kwaliteit van leven toont geen buffereffect aan van continuiteit van de zorg. In de multivariate analyses die in hoofdstuk 9 zijn beschreven, worden de variabelen 'het aantal zorgverleners', 'taakafbakening', 'overeenstemming t.a.v. zorgbehoeften' 
en 'tevredenheid over de zorgverlening' gebruikt. Als criterium voor de keuze van de variabele is een significante samenhang met kwaliteit van leven gehanteerd. Overeenstemming ten aanzien van zorgbehoeften is meegenomen vanuit de theoretische overweging dat het kunnen inschatten van de zorgbehoeften van de patiënt medebepalend is voor de mate waarin het zorgaanbod aansluit bij de zorgbehoeften van de patiënt en daarmee de kwaliteit van leven beïnvloedt. Bovendien is er een consistente positieve samenhang gevonden tussen deze variabele en kwaliteit van leven op alle metingen.

Tabel 7.9

Samenvatting van de bivariate verbanden tussen indicatoren voor continuiteit van de zorgverlening en kwaliteit van leven.

t 1

t3

beloop

$\begin{array}{lccc}\text { aantal zorgverleners } & 0 & + & + \\ \text { contact ha - spe } & 0 & 0 & 0 \\ \text { taakovereenstemming } & - & - & 0 \\ \text { dezelfde specialist } & 0 & \text { n.v.t } \\ \text { bezoek na ontslag } & 0 & 0 & - \\ \text { tevredenheid } & + & 0 & 0 \\ \text { overeenstemming ha - pat } & 0 & \\ & \\ 0=\text { geen significant verband gevonden } & \\ +=\text { significant verband gevonden in de verwachte richting } & \\ -=\text { significant verband gevonden tegengesteld aan de verwachting. }\end{array}$


, 


\section{Sociale steun}

Behalve de kenmerken van professionele zorgverlening zijn ook structurele en functionele aspecten van sociale steun drie keer gemeten. In paragraaf 8.1 worden de structurele kenmerken beschreven. Van het sociale netwerk van patiënten zijn tijdens de drie meetmomenten de grootte van het netwerk, de samenstelling en de dichtheid van het netwerk onderzocht.

De functionele aspecten komen in paragraaf 8.2 aan bod. Ze betreffen de mate van ervaren emotionele en praktische steun alsmede de wederkerigheid van de steun. In paragraaf 8.3 wordt de relatie tussen ziektekenmerken en sociale steun beschreven. Tenslotte wordt de onderlinge samenhang van de variabelen in beschouwing genomen, alsmede de samenhang tussen indicatoren voor sociale steun en (het beloop van) kwaliteit van leven (8.4).

\subsection{De structurele kenmerken van het sociale netwerk}

In tabel 8.1 worden de grootte en de samenstelling van de netwerken weergegeven. De patiënten hebben gemiddeld een vrij klein netwerk (gemiddeld 8.5 personen), vergeleken met andere patiëntengroepen. Zo vindt De Witte (1991) bij patiënten met reumatoïde arthritis een gemiddelde netwerkgrootte van 11.0 en Bal (1992) bij dezelfde patiëntencategorie een gemiddelde van 9.9. De Witte rapporteert bij patiënten met een dwarslaesie een gemiddelde netwerkomvang van 12.3. Janssen (1992) vindt bij patiënten met de ziekte van Crohn een gemiddelde netwerkgrootte van 10.1, bij patiënten met de ziekte van Bechterew een gemiddelde van 7.9 en bij 'gezonden' een gemiddelde netwerkgrootte van 11.3. Feather (1989) constateert bij 681 kankerpatiënten een met onze gegevens vergelijkbare gemiddelde netwerkgrootte, namelijk 8.1.

De gemiddelde omvang van de sociale netwerken neemt significant af in de loop van de tijd ( $\mathrm{t} 1-\mathrm{t} 3, \mathrm{t}=2.4 ; \mathrm{p}<0.05)$. De gemiddeld afname is tamelijk klein: minder dan één netwerklid.

De gemiddelde afname van het aantal personen in het persoonlijke netwerk komt overeen met onze verwachtingen (zie hoofdstuk 2). 
In het begin van het ziekteproces krijgen de respondenten veelal aandacht van mensen uit de omgeving. Na verloop van tijd neemt die aandacht af. Zo vertelde een 50-jarige vrouw met borstkanker: "In het begin kreeg ik veel bezoek van kennissen en vrienden, mijn schoonfamilie niet, die vonden het eng. Mijn man bleef ook vaker thuis. Nu gaat hij weer weg en alles is weer in zijn gewone doen. I $\mathrm{k}$ mis de aandacht die ik kreeg".

Omdat de patiënt waarschijnlijk niet meer zo kan functioneren als voor dat hij ziek werd, nemen ook contacten met collega's, vrienden of kennissen uit het verenigingsleven af.

De meerderheid van de personen die patiënten noemen in hun netwerk zijn familieleden. Dit komt overeen met de resultaten van andere onderzoeken (De Witte, 1991 ; Janssen, 1992 ; Bal, 1992). Wat in tabel 8.1 opvalt is dat ondanks dat er sprake is van een gemiddelde afname de verhouding tussen familieleden en niet familieleden nagenoeg hetzelfde blijft. Dit impliceert dat het verlies van netwerkleden in beide categorieën even groot is. De verwachting was dat de afname juist bij de nietfamilieleden zou plaatsvinden.

Tabel 8.1 Vergelijking van de grootte van het sociale netwerk en het percentage familieleden op $t 1$ en 13 . t-test paren $(n=51)$.

t1

\begin{tabular}{|c|c|c|c|c|c|}
\hline & gem & sd. & gem. & sd. & $\mathrm{p}$ \\
\hline Netwerkgrootte & 8.5 & 4.6 & 7.7 & 4.2 & $\bullet$ \\
\hline Percentage familieleden & $81 \%$ & 21 & $82 \%$ & 21 & n.s \\
\hline$* p<0.05$ & & & & & \\
\hline
\end{tabular}

De scores op de variabele 'dichtheid van het netwerk' veranderen niet in de tijd. De meeste patiënten hebben een zeer dicht netwerk waarin iedereen elkaar kent en personen onderling veel contacten hebben. Op grond van de frequentieverdeling is een onderscheid gemaakt tussen patiënten met een zeer dicht netwerk en patiënten met een minder dicht netwerk. De meerderheid van de patiënten $(69 \%)$ heeft een zeer dicht netwerk. Het percentage familieleden en de dichtheid van het netwerk hangen positief met elkaar samen (zie bijlage J). De dichtheid van de netwerken kan ook verklaard worden vanuit het feit dat een groot deel van de patiënten op het platteland woont. De kans dat mensen uit een netwerk elkaar kennen is waarschijnlijk groter in een klein dorp dan in de stad.

\subsection{De functionele kenmerken van sociale steun}

Bij elke patiënt is op de verschillende meetmomenten de gemiddelde ervaren emotionele en praktische steun per netwerklid vastgesteld. In hoofdstuk drie is 
beschreven hoe deze variabelen berekend zijn. In tabel 8.2 staan de waarden voor het eerste en derde meetmoment.

Tabel 8.2 Vergelijking van ervaren emotionele en praktische steun op $t 1$ en $t 3$. $t$-test paren ( $n=51)$.

t1

t3

\begin{tabular}{lccccc} 
& gem & s.d & gem & s.d & $p$ \\
Emotionele steun per netwerklid & 4.0 & .74 & 3.8 & .67 & $\ldots$ \\
Praktische steun per netwerklid & 3.0 & 1.2 & 2.9 & 1.0 & n.s \\
$* \mathrm{p}<0.05$ & & & & & \\
\hline
\end{tabular}

De patiënten krijgen gemiddeld genomen redelijk veel emotionele steun (gerelateerd aan de minimum-maximum score). De scores op de variabele gemiddelde emotionele steun zijn vergelijkbaar met de scores van andere patiëntengroepen zoals patiënten met de ziekte van Crohn (4.0) en de ziekte van Bechterew (3.8) (Janssen, 1992). $\mathrm{Er}$ is een significante afname van de emotionele steun per netwerklid waarneembaar $(\mathrm{t} l-\mathrm{t} 3, \mathrm{t}=2.32, \mathrm{p}<0.05)$. De gemiddelde hoeveelheid praktische steun per netwerklid verandert niet significant in de loop der tijd, maar de tendens is dezelfde als bij emotionele steun: de ervaren steun neemt gemiddeld af na verloop van tijd. Tenslotte is de wederkerigheid van de steun bepaald door de totale hoeveelheid door de patiënt aan anderen gegeven emotionele c.q. praktische steun te delen door de totale hoeveelheid ervaren emotionele c.q. praktische steun. De scores (zie tabel 8.3) op deze maat voor wederkerigheid van de emotionele steun liggen gemiddeld rond de 1.0. Dat wil zeggen dat er een zeker evenwicht is. Patiënten geven ongeveer evenveel steun als dat ze krijgen. Hetzelfde geldt voor de wederkerigheid van de praktische steun. De mate van wederkerigheid van de emotionele en praktische steun vertoonden gemiddeld geen significante veranderingen in de loop van de tijd.

Tabel 8.3 Vergelijking van wederkerigheid van sociale steun (gegeven/ervaren steun) op $\mathbf{t} 1$ en t3. t-test paren $(n=51)$.

\begin{tabular}{lrrrrl} 
& gem & s.d & gem & s.d & p \\
emotioneel & .97 & .20 & .98 & .22 & n.s \\
praktisch & 1.10 & .71 & .96 & .54 & n.s \\
\hline
\end{tabular}




\subsection{Samenhang tussen ziekte/behandelingskenmerken en sociale steun}

In paragraaf 2.8 van deze dissertatie is aangegeven dat er een samenhang wordt verwacht tussen de ernst van de ziekte en sociale steun. Ernstig ziek-zijn zou kunnen leiden tot gevoelens van onmacht, onbehagen en verminderde interesse van mensen in de directe omgeving van de patiënt. Het is echter ook mogelijk dat de patiënt zelf zijn interesse in anderen verliest (Ros, 1990; Dunkel-Schetter en Wortman, 1982). Uitgaande van de 'ruiltheorie' die in hoofdstuk 2 is beschreven, kan dat op den duur leiden tot verlies van contacten. Onderzoek van Tempelaar (1989) daarentegen laat zien dat de hoeveelheid steun toeneemt naarmate het met de patiënt slechter gaat. In ons onderzoek zijn we nagegaan wat de relatie is tussen de ziektekenmerken en sociale steun. Zowel bij de eerste als bij derde meting zijn correlaties berekend tussen de ernst c.q. de ziekteduur (tijdsverloop sinds diagnose) en de netwerkgrootte, samenstelling, dichtheid, emotionele steun, praktische steun en wederkerigheid (zie tabel 8.4).

Tabel 8.4 Samenhang tussen ernst c.q ziekteduur en kenmerken van het netwerk/sociale steun op $\mathrm{t} 1$ en $\mathrm{t} 3$. Pearson correlaties $(n=51)$.

\begin{tabular}{lll}
\hline & ernst $\mathrm{t} 1$ & ziekteduur $\mathrm{t} 1$ \\
$\mathrm{t} 1$ & & \\
netwerkgrootte & .01 & -.12 \\
percentage familieleden & .04 & .17 \\
dichtheid & -.13 & .03 \\
emotionele steun & -.22 & .11 \\
praktische steun & -.07 & .10 \\
wederkerigheid emotioneel & .13 & .06 \\
wederkerigheid praktisch & .00 & .03 \\
& & \\
t3 & ernst t 1 & ziekteduur $\mathrm{t} 1$ \\
netwerkgrootte & .02 & -.05 \\
percentage familieleden & -.06 & .17 \\
emotionele steun & -.15 & .07 \\
praktische steun & -.15 & .13 \\
wederkerigheid emotioneel & .07 & .07 \\
wederkerigheid praktisch & -.06 & -.04 \\
& & \\
\hline
\end{tabular}

Er is geen enkele significante samenhang gevonden tussen de ernst respectievelijk tijd sinds diagnose en de indicatoren voor sociale steun. Er zit weinig variatie in de ziekteduur. De meesten van deze patiënten zijn drie tot vier maanden ziek. Dit verklaart waarschijnlijk waarom we geen significante correlaties hebben gevonden tussen de 'steun-variabelen' en tijd sinds diagnose.

Met behulp van éen-weg variantieanalyses is nagegaan of er verschillen zijn tussen diagnose- en behandelingsgroepen met betrekking tot bovengenoemde kenmerken. Er zijn geen significante verschillen gevonden. 


\subsection{De samenhang tussen de indicatoren van sociale steun en kwaliteit van leven}

Om de samenhang tussen de verschillende aspecten van sociale steun te bestuderen zijn correlatiematrices gemaakt (zie bijlage J). Uit de correlaties blijkt onder andere dat naarmate netwerken groter zijn, de dichtheid lager is en dat hoe groter het percentage familieleden is, hoe dichter het netwerk is. Opvallend is ook dat naarmate het netwerk groter is, de hoeveelheid ervaren steun per netwerklid minder is. Een verklaring hiervoor is dat patiënten waarschijnlijk een klein kernnetwerk hebben van mensen waarvan zij daadwerkelijk steun ervaren. Daarnaast noemen de patiënten soms nog mensen in het netwerk die iets verder afstaan, bijvoorbeeld kennissen of buren, waar zij voornamelijk 'gezelligheidscontacten' mee hebben, maar die geen daadwerkelijke steun bieden. Als patiënten deze personen noemen als netwerkleden, dan wordt de gemiddelde hoeveelheid steun per netwerklid kleiner dan wanneer men zich beperkt tot het kernnetwerk. Dezelfde verklaring zou kunnen gelden voor het feit dat een dicht netwerk samengaat met meer ervaren steun per netwerklid.

Er blijkt een positieve samenhang te bestaan tussen de gemiddelde hoeveelheid ervaren praktische steun en emotionele steun. De wederkerigheid van de steun blijkt steeds samen te hangen met de hoeveelheid steun per netwerklid; als patiënten veel steun krijgen, is de mate van wederkerigheid lager. Deze samenhang is zo sterk dat besloten is om alleen de 'zuivere maten' emotionele steun en praktische steun in verdere analyses te gebruiken.

Om de relatie tussen de verschillende indicatoren van sociale steun en kwaliteit van leven te bepalen zijn correlaties op de verschillende meetmomenten berekend. De correlaties worden in tabel 8.5 weergegeven. Uit deze tabel kan worden geconcludeerd dat de structurele kenmerken van het sociale netwerk, de grootte en de dichtheid van het netwerk en het percentage familieleden, geen significante samenhang vertonen met kwaliteit van leven. Bij de eerste meting blijkt er een significante samenhang te bestaan tussen de hoeveelheid emotionele steun per netwerklid en de kwaliteit van leven; hoe minder emotionele steun per netwerklid de patiënt ervaart, hoe slechter de kwaliteit van leven. Praktische steun vertoont een consistente, negatieve, doch niet significante samenhang met kwaliteit van leven.

Tabel 8.5 Samenhang tussen kenmerken van het sociale netwerk/sociale steun en kwaliteit van leven op $t 1$ en $\mathbf{t} 3$. Pearson correlaties $(n=51)$.

\begin{tabular}{lll}
\hline & kwaliteit leven t1 & kwaliteit leven t3 \\
& .04 & -.04 \\
grootte & -.03 & -.07 \\
percentage familieleden & .19 & -.04 \\
dichtheid & $.27^{*}$ & .08 \\
emotionele steun/p.netwerklid & -.11 & -.17 \\
praktische steun/p. netwerklid & & \\
& & \\
\hline
\end{tabular}


Opvallend is dat de samenhang tussen emotionele steun en kwaliteit van leven niet consistent is. In de tabel 8.6 worden de kenmerken van het sociale netwerk en de mate waarin er sprake is van steun, gerelateerd aan het beloop van kwaliteit van leven voor de patiënten. Met behulp van t-toetsen is nagegaan of de groepen (positief c.q. negatief/gelijk beloop van kwaliteit van leven) van elkaar verschillen.

Tabel 8.6. Kenmerken van het sociale netwerk en sociale steun bij patiënten die vooruit gaan of achteruit gaan/gelijk blijven op kwaliteit van leven op $t 1$ en $t 3$. $t$-test groep $(n=51)$.

\begin{tabular}{|c|c|c|c|c|c|c|}
\hline & 11 & & & t3 & & \\
\hline & gem & s.d & $p$ & gem & s.d & $p$ \\
\hline $\begin{array}{l}\text { Grootte netwerk } \\
\text { groep } 1 \text { achteruit } \\
\text { groep } 2 \text { vooruit }\end{array}$ & $\begin{array}{l}9.3 \\
7.5\end{array}$ & $\begin{array}{l}4.7 \\
4.5\end{array}$ & n.s & $\begin{array}{l}8.3 \\
7.1\end{array}$ & $\begin{array}{l}3.9 \\
4.5\end{array}$ & n.s \\
\hline $\begin{array}{l}\text { Percentage familie } \\
\text { groep } 1 \text { achteruit } \\
\text { groep } 2 \text { vooruit }\end{array}$ & $\begin{array}{l}83 \\
78\end{array}$ & $\begin{array}{l}20.5 \\
21.9\end{array}$ & n.s & $\begin{array}{l}86 \\
78\end{array}$ & $\begin{array}{l}18.5 \\
22.2\end{array}$ & n.s \\
\hline $\begin{array}{l}\text { Emotionele steun } \\
\text { groep } 1 \text { achteruit } \\
\text { groep } 2 \text { vooruit }\end{array}$ & $\begin{array}{l}3.9 \\
4.0\end{array}$ & $\begin{array}{l}.68 \\
.81\end{array}$ & n.s & $\begin{array}{l}3.6 \\
4.0\end{array}$ & $\begin{array}{l}.63 \\
.65\end{array}$ & $\cdots$ \\
\hline $\begin{array}{l}\text { Praktische steun } \\
\text { groep } 1 \text { achteruit } \\
\text { groep } 2 \text { vooruit }\end{array}$ & $\begin{array}{l}2.8 \\
3.3\end{array}$ & $\begin{array}{l}1.2 \\
1.1\end{array}$ & n.s & $\begin{array}{l}2.8 \\
3.1\end{array}$ & $\begin{array}{l}.93 \\
.99\end{array}$ & n.s \\
\hline$* p<0.05$ & & & & & & \\
\hline
\end{tabular}

Uit de tabel $8.6 \mathrm{kan}$ worden geconcludeerd dat patiënten met een positief beloop van kwaliteit van leven, met name bij de derde meting, meer emotionele steun per netwerklid ontvangen dan de patiënten met een negatief beloop. Met betrekking tot de grootte van het netwerk, het percentage familieleden, de dichtheid van de netwerken en praktische steun zijn geen significante verschillen tussen de twee groepen patiënten gevonden. Wat opvalt in de tabel is dat bij patiënten die achteruit gaan of hetzelfde blijven scoren op de maat voor kwaliteit van leven, in grotere mate sprake is van verkleining van het netwerk en afname van emotionele steun dan bij de groep patiënten die vooruit zijn gegaan. Bij de patiënten die vooruit zijn gegaan neemt de praktische steun gemiddeld meer af dan bij patiënten die achteruit zijn gegaan of gelijk blijven scoren.

Omdat er blijkbaar een relatie bestaat tussen de veranderingen in kwaliteit van leven en de veranderingen in steun zijn verschilscores $(\mathrm{t} 3-\mathrm{t} 1)$ berekend voor de variabelen grootte, emotionele steun per netwerklid en praktische steun per netwerklid. Als we de verschilscores van beide groepen, zoals in tabel 8.7 staat vermeld, met elkaar vergelijken blijkt er inderdaad een significant verschil te zijn in de verandering van de hoeveelheid emotionele steun $(p<0.10)$. Bij patiënten met een negatief beloop van kwaliteit van leven (of onveranderde scores) is de afname van emotionele steun 
groter dan bij patiënten met een positief beloop. Dit komt overeen met het onderzoek van De Witte (1991) waaruit blijkt dat een afname van de hoeveelheid steun een belangrijke voorspeller is van een relatief negatief beloop van het functioneren van revalidatiepatiënten.

Tabel 8.7 Veranderingsscores $(t 3-t 1)$ van netwerkgrootte/ervaren sociale steun bij patiënten die vooruit gaan of achteruit gaan/gelijk blijven op kwaliteit van leven. t-test groep $(n=51)$.

$\begin{array}{lrrr} & \text { gem } & \text { sd. } & \text { p } \\ \text { Verandering grootte netwerk } & & & \\ \text { groep } 1 \text { achteruit } & -1.10 & 2.7 & \text { n.s } \\ \text { groep } 2 \text { vooruit } & -0.40 & 1.6 & \\ & & & \\ \text { Verandering ervaren emotionele steun } & & & \\ \text { groep } 1 \text { achteruit } & -0.34 & .68 & * \\ \text { groep } 2 \text { vooruit } & -0.07 & .52 & \\ & & & \\ \text { Verandering ervaren praktische steun } & & & \\ \text { groep } 1 \text { achteruit } & -0.05 & .66 & \text { n.s } \\ \text { groep } 2 \text { vooruit } & -0.14 & .84 & \\ & & & \\ \text { - p }<0.10 & & & \end{array}$

Het is aannemelijk dat er een samenhang bestaat tussen de veranderingen in de emotionele steun en het beloop van kwaliteit van leven. Uitspraken over de causaliteit van deze relatie kunnen op basis van deze gegevens niet worden gedaan.

\subsection{Buffereffect van sociale steun}

In hoofdstuk 1 is beschreven dat sociale steun mogelijk een buffereffect heeft. Dat wil zeggen dat de mate van sociale steun een versterkende dan wel verzachtende werking kan hebben op de effecten van ziekte en behandeling op kwaliteit van leven (pijl 4 in het onderzoeksmodel). We willen onderzoeken of sociale steun een modererende invloed uitoefent op de relatie tussen ziekte en kwaliteit van leven.

Daartoe hebben we de groep patiënten verdeeld in diegenen die relatief hoog scoren op de variabele emotionele steun ( $t 1)$ en in degenen die relatief laag scoren op deze variabele. Hetzelfde is gedaan voor praktische steun. Als criterium voor de indeling is de mediaan gebruikt.

Op deze wijze komen 27 patiënten terecht in de groep die relatief hoog scoort op emotionele steun (dat wil zeggen vier of hoger) en 22 in de groep die lager dan vier scoort. Voor beide groepen apart is een Pearson correlatie berekend tussen de ernst van de ziekte en kwaliteit van leven op het eerste meetmoment. De correlatie bedraagt voor de patiënten met een hoge score op emotionele steun .22 en voor de patiënten met weinig steun .40. Met behulp van de $\mathrm{z}$-toets voor correlatiecoëffici- 
enten is berekend of deze correlaties significant van elkaar verschillen. Dit blijkt niet het geval te zijn ( $U=0.65$, n.s.).

Dezelfde procedure hebben we gevolgd om de effecten van praktische steun te bestuderen. Bij patiënten $(n=23)$ die relatief hoog scoren op praktische steun, dat wil zeggen 3.2 of hoger is de correlatie tussen ernst en kwaliteit van leven .48 en bij patiënten met relatief weinig praktische steun .32 . Ook deze correlaties verschillen niet significant van elkaar $(U=0.67$, n.s. $)$.

De correlatie tussen de ernst van de ziekte en kwaliteit van leven op het derde meetmoment bij mensen met een hoge score op emotionele steun is lager $(r=0.10)$ dan bij mensen met een relatief lage score op emotionele steun $(r=.25)$, maar dit verschil is niet significant. Bij praktische steun verschillen de correlaties nauwelijks; .24 voor mensen met relatief veel praktische steun en .27 voor patiënten met een relatief lage score op praktische steun.

Uit deze analyses komen geen aanwijzingen naar voren voor een buffereffect. Voorzover in het voorgaande relaties tussen steun en kwaliteit van leven zijn gevonden, kunnen deze blijkbaar als directe effecten geïnterpreteerd worden.

\subsection{Samenvatting en conclusies}

De patiënten blijken bij de eerste meting gemiddeld over een vrij klein sociaal netwerk te beschikken, gemiddeld 8.5 personen. Het merendeel van deze netwerkleden bestaat uit familie van de patiënt. De gemiddelde netwerkomvang neemt na verloop van tijd significant af, zoals ook verwacht werd. De netwerken hebben gemiddeld een hoge dichtheid; in de meeste gevallen kennen de netwerkleden elkaar en hebben onderling ook veel contact.

Met betrekking tot de ervaren steun kan het volgende worden geconcludeerd. Gemiddeld ervaren de patiënten bij de eerste meting redelijk veel emotionele steun. $\mathrm{Na}$ verloop van tijd vindt er een afname plaats van de hoeveelheid emotionele steun per netwerklid. De verwachtingen die in hoofdstuk 2 werden geformuleerd worden hiermee gedeeltelijk bevestigd.

De balans tussen gegeven en ervaren steun is gemiddeld genomen nagenoeg in evenwicht. Er is dus geen sprake van afname van de wederkerigheid van de steun zoals we verwacht hadden.

De bestudering van de samenhang tussen ziekte- en behandelingskenmerken en de indicatoren van sociale steun levert geen significante verbanden op.

Uit de correlaties tussen de indicatoren van sociale steun en kwaliteit van leven blijkt dat er een samenhang bestaat tussen emotionele steun per netwerklid en kwaliteit van leven, in de richting die werd verwacht. Weinig emotionele steun per netwerklid hangt samen met een slechte kwaliteit van leven en een negatief beloop van kwaliteit van leven. Tevens blijkt er een tendens te zijn dat bij patiënten met een negatief beloop van kwaliteit van leven, de afname van de hoeveelheid ervaren emotionele steun sterker is dan bij de patiënten met een positief beloop. Het blijft de vraag of een slechte kwaliteit van leven leidt tot minder emotionele steun vanuit het netwerk, of dat weinig steun leidt tot een slechte kwaliteit van leven. We kunnen alleen concluderen dat er een samenhang bestaat.

Een buffereffect van sociale steun hebben we niet kunnen aantonen. 
Tenslotte wordt in tabel 8.8 een samenvatting gegeven van de gevonden bivariate verbanden tussen indicatoren voor sociale steun en kwaliteit van leven in relatie tot de in hoofdstuk 2 geformuleerde verwachtingen. In de multivariate analyses die in het volgende hoofdstuk worden beschreven, zullen de variabelen emotionele en praktische steun per netwerklid worden gebruikt. Als criterium voor deze keuze is op de eerste plaats een significante samenhang met kwaliteit van leven gehanteerd. Tevens wordt de variabele ervaren praktische steun opgenomen in de analyses vanwege de consistente (negatieve) samenhang met kwaliteit van leven.

Tabel 8.8 Samenvatting van de bivariate verbanden tussen sociale steun en kwaliteit van leven.

\begin{tabular}{llll}
\hline & $\mathrm{t} 1$ & $\mathrm{t} 3$ & beloop \\
& & & \\
\hline & 0 & 0 & 0 \\
- grootte netwerk & 0 & 0 & 0 \\
- dichtheid & 0 & 0 & 0 \\
- \% familieleden & + & 0 & + \\
- emotionele steun p.netwerklid & + & 0 & 0 \\
- praktische steun p.netwerklid & 0 & & \\
$\begin{array}{l}\text { - geen significant verband gevonden } \\
+=\text { significant verband gevonden in de verwachte richting }\end{array}$ & \\
\end{tabular}




\section{Determinanten van kwaliteit van leven}

De probleemstelling van ons onderzoek betreft de vraag of er behalve invloed van ziekte en behandeling ook sprake is van invloed van continuïteit van de professionele zorgverlening, sociale steun, sociale positie en beheersingsoriëntatie op (het beloop van) kwaliteit van leven. In de hoofdstukken 6 tot en met 8 hebben we inzicht verkregen in de bivariate relaties tussen de genoemde variabelen en kwaliteit van leven. De relatie tussen de variabelen is eerst transversaal bestudeerd, voor de eerste en derde meting apart. Vervolgens is de groep patiënten met een positief beloop van kwaliteit van leven vergeleken met patiënten van wie de kwaliteit van leven ongeveer gelijk is gebleven of achteruit is gegaan.

Naar aanleiding van deze bivariate analyses zijn een aantal variabelen geselecteerd die samenhang vertonen met kwaliteit van leven. In dit hoofdstuk beschrijven we de multivariate analyses die uitgevoerd zijn met dit beperkte aantal (geselecteerde) variabelen. Hiermee wordt getracht te onderzoeken welke variabelen een onafhankelijke significante samenhang vertonen met kwaliteit van leven en na te gaan welke variabelen de variantie in het beloop van kwaliteit van leven verklaren.

In paragraaf 9.1 worden de geselecteerde variabelen en de correlaties tussen deze variabelen besproken. Paragraaf 9.2 gaat over de transversale analyses die zijn uitgevoerd om inzicht te krijgen in de relatie tussen de onafhankelijke variabelen en kwaliteit van leven op de verschillende meetmomenten. Hierbij is gebruik gemaakt van multiple regressie-analyses. In paragraaf 9.3 wordt ingegaan op de longitudinale analyses. Hierbij staat centraal: het verklaren van verschillen tussen de groep patiënten met een positief beloop van kwaliteit van leven en de groep patiënten die achteruit is gegaan dan wel gelijk is blijven scoren (in kwaliteit van leven). Hierbij is gebruik gemaakt van discriminantanalyses. In paragraaf 9.4 wordt de vergelijkingsgroep 'Maastricht' behandeld. 


\subsection{De geselecteerde onafhankelijke variabelen en hun onderlin- ge samenhang}

In deze paragraaf wordt nog eens weergegeven welke variabelen geselecteerd zijn voor de multivariate analyses. Het gaat om die variabelen die bij de bivariate transversale of bij de longitudinale analyses een significante samenhang vertonen met kwaliteit van leven. Daarnaast zijn de variabelen 'overeenstemming over de zorgbehoeften' en praktische steun opgenomen op grond van theoretische overwegingen en op grond van een consistente, weliswaar niet significante, samenhang met kwaliteit van leven. In tabel 9.1 wordt een schematische weergave van de variabelen en hun relatie tot kwaliteit van leven gepresenteerd.

Tabel 9.1 Schematische weergave van de bivariate verbanden van de geselecteerde onafhankelijke variabelen met kwaliteit van leven $(t 1, t 3$ en beloop)

Transversaal
$\mathrm{t} 1 \mathrm{t} 3$

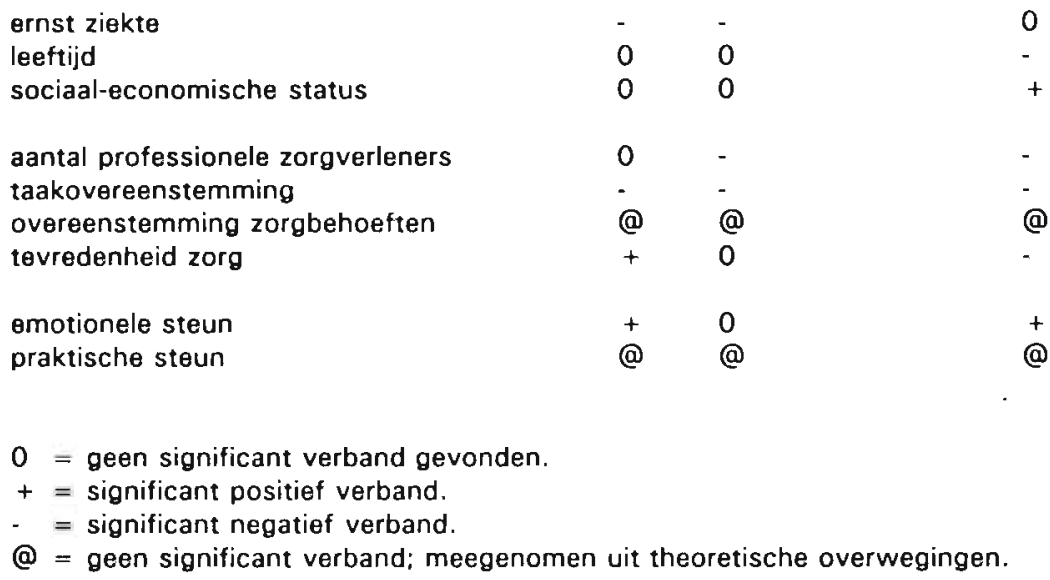

In de vorige hoofdstukken is gebleken dat naarmate patiënten volgens objectieve maatstaven (prognose en stadium van de ziekte) ernstiger ziek zijn, zij hun kwaliteit van leven negatiever beoordelen. De objectieve ernst bij het eerste meetmoment vertoont geen samenhang met het beloop van kwaliteit van leven.

Een hoge sociaal-economische status hangt samen met een positief beloop van kwaliteit van leven. Een hoge leeftijd beïnvloedt het beloop van kwaliteit van leven negatief.

Zowel bij de transversale ( 3 ) als de longitudinale analyse is gebleken dat patiënten met een relatief slechte kwaliteit van leven c.q. negatief beloop, met relatief veel verschillende professionele zorgverleners te maken hebben en dat er bij patiënten met een relatief lage kwaliteit van leven (t1) c.q. een negatief/gelijk 
beloop een relatief grote taakovereenstemming bestaat tussen huisarts en specialist. Op het eerste meetmoment is een positieve samenhang gevonden tussen kwaliteit van leven en de tevredenheid over de zorg. Een negatief beloop van kwaliteit van leven blijkt echter samen te gaan met meer tevredenheid over de zorg op het derde meetmoment.

Tenslotte werd een positief verband gevonden tussen emotionele steun en kwaliteit van leven, bij de transversale analyse op het eerste meetmoment. Bovendien werd bij de longitudinale analyses gevonden dat patiënten die meer emotionele steun ervaren, een positiever beloop hebben van kwaliteit van leven.

Naast deze significante verbanden zijn er ook enkele verbanden gevonden die niet significant waren maar toch het vermelden waard zijn: praktische steun correleert bij de transversale analyses negatief met kwaliteit van leven: een lage kwaliteit van leven hangt zowel op $t 1$ als op $t 3$ samen met meer praktische steun. Wat het beloop van kwaliteit van leven betreft, hangt een positief beloop samen met meer praktische steun.

Voorts zijn zowel bij de transversale als de longitudinale analyses positieve verbanden gevonden tussen de mate van overeenstemming over de zorgbehoeften en kwaliteit van leven.

Om inzicht te krijgen in de onderlinge samenhang tussen de onafhankelijke variabelen zijn correlaties berekend, voor de eerste en derde meting apart. In tabel 9.2 zijn de correlaties weergegeven. Bij iedere variabele wordt steeds op de eerste regel de correlatie op het eerste meetmoment weergegeven, op de tweede regel de correlatie op het derde meetmoment. Inzicht in de intercorrelaties van de onafhankelijke variabelen is van belang omdat we willen nagaan of er sprake is van multicollineariteit. Multicollineariteit ontstaat als twee variabelen in een matrix sterk correleren en tevens gelijke correlatiepatronen vertonen met andere variabelen. Een dergelijke nauwe samenhang tussen onafhankelijke variabelen beïnvloedt de regressiegewichten en correlaties in de multiple regressieanalyse en kan leiden tot redundante en misleidende informatie. Het is dan zinloos om beide variabelen op te nemen in de multivariate analyses. Een van de variabelen moet dan uit de analyses worden gelaten of de variabelen moeten worden samengevoegd.

Bij de bestudering van tabel 9.2 vallen enkele zaken op. Zo kan worden geconcludeerd dat er geen hoge correlaties voorkomen tussen de geselecteerde variabelen. De hoogste coëfficiënt bedraagt .49. Dit betekent dat bij de multivariate analyses weinig problemen zullen ontstaan wat collineariteit betreft.

Opvallend is dat er soms redelijk grote verschillen bestaan tussen de correlaties op t 1 en $\mathrm{t} 3$. De interpretatie van deze verschillen is problematisch, soms zijn de verschillen te begrijpen, soms ook niet.

Een opvallende inhoudelijke bevinding is dat behalve enst van de ziekte ook enkele andere variabelen met kwaliteit van leven samenhangen. Interessant is dat het aantal betrokken professionele zorgverleners en de mate van takovereenstemming nauwelijks samenhang te vertonen met de ernst van de ziekte, maar wel met kwaliteit van leven. Het inschakelen van professionele zorg en de taakovereen- 
stemming tussen de professionals worden kennelijk meer bepaald door hoe patiënten zich voelen en hoe zij functioneren dan door de objectieve ernst van de ziekte.

Tabel 9.2 Pearson correlaties tussen de onafhankelijke variabelen en tussen de onafhankelijke variabelen en kwaliteit van leven, op de eerste meting (regel 1 ) en de derde meting (regel 2$),(n=51)$.

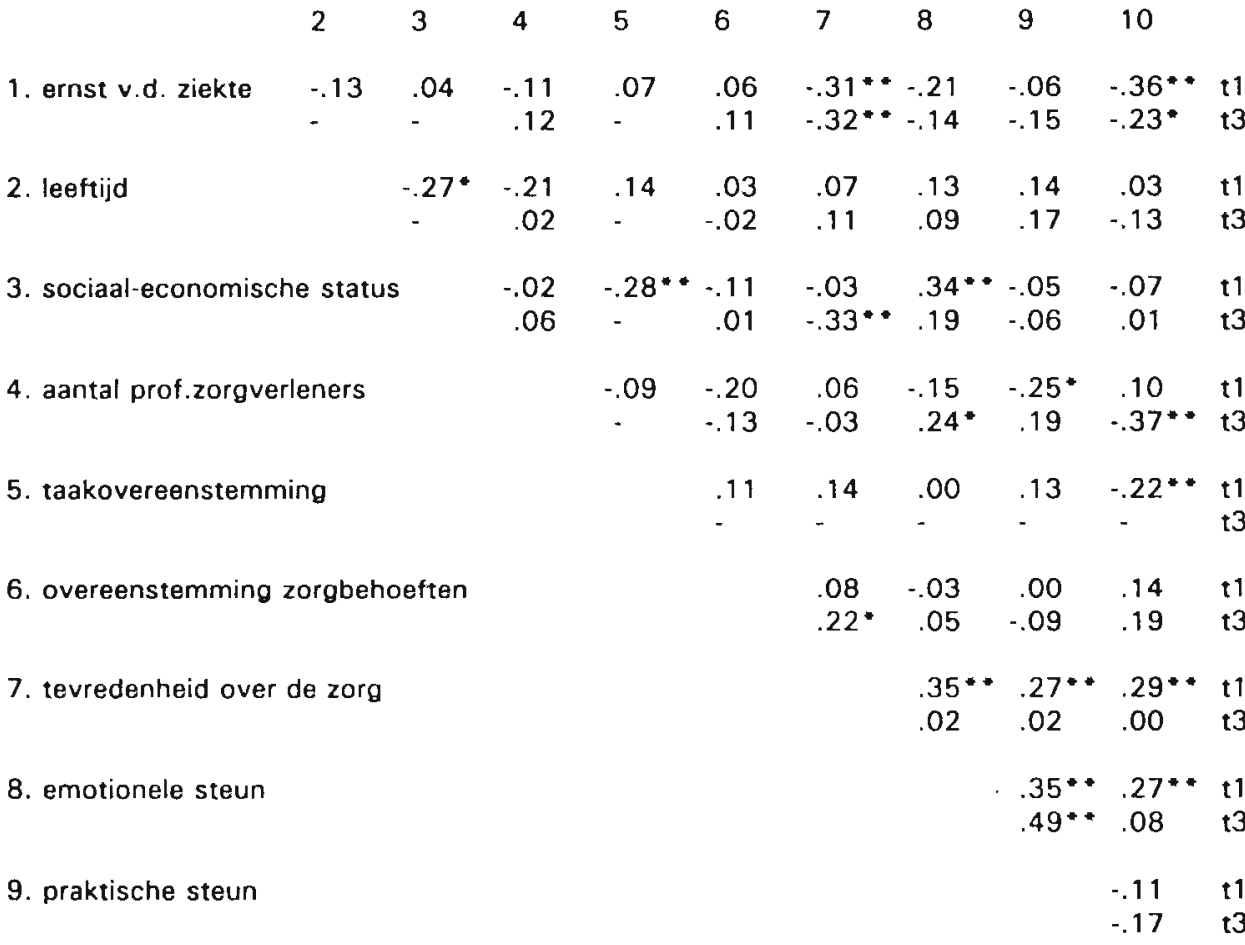

10.kwaliteit van leven

$* \mathbf{p}<0.10, \cdots p<0.05$

\subsection{De transversale analyses}

Om de determinanten van kwaliteit van leven te bepalen is een multiple regressie analyse uitgevoerd, voor de eerste en derde meting apart. De verhouding tussen het aantal onafhankelijke variabelen en onderzoekseenheden is $5: 1$. Deze verhouding is verre van ideaal, maar nog net toelaatbaar (Tabachnick, 1983). Een van de assumpties bij het uitvoeren van regressieanalyse met deze 'case to 
variable ratio' is dat de residuen (voorspellingsfouten) normaal verdeeld moeten zijn. Aan deze voorwaarde is voldaan.

Bij de regressieanalyses zijn alle variabelen tegelijk in de vergelijking opgenomen. Het probleem van de ontbrekende waarden is opgelost door deze te vervangen door de gemiddelde score op de variabelen. Dit blijkt vooral van belang te zijn bij de variabelen taakovereenstemming en overeenstemming over de zorgbehoeften.

In eerste instantie zijn alle onafhankelijke variabelen in de analyses gebruikt. Uit deze analyses blijkt dat sociaal-economische status een zogenaamde supressorvariabele is. Een supressor-variabele onderdrukt de variantie van andere onafhankelijke variabelen waarmee de supressor-variabele samenhangt. Een aanwijzing voor de veronderstelling dat sociaal-economische status een supressor-variabele is wordt gevormd door het feit dat de B - waarde bij sociaal-economische status aanzienlijk hoger is dan de nulde orde correlatie tussen sociaal-economische status en kwaliteit van leven, zowel bij de eerste als bij de derde meting. Uit tabel 9.2 is bovendien gebleken dat sociaal-economische status samenhangt met taakovereenstemming, leeftijd, emotionele steun en tevredenheid over de zorg. Sociaaleconomische status zal waarschijnlijk de variantie van deze variabelen onderdrukken. Duidelijk is dat sociaal-economische status een rol speelt in de verklaring van kwaliteit van leven. Door de samenhang met andere variabelen is het echter moeilijk te achterhalen op welke (indirecte) wijze sociaal-economische status kwaliteit van leven beïnvloedt. In de analyses die volgen, hebben we daarom sociaal-economische status steeds weggelaten.

Omdat de ontbrekende waarden bij de regressieanalyses vervangen zijn door gemiddelden is nagegaan of de structuur van de resultaten hetzelfde blijft als de variabele taakovereenstemming werd weggelaten uit de analyses. Er zijn geen wezenlijk andere resultaten gevonden zodat taakovereenstemming wel in de analyse kan worden opgenomen.

In tabel 9.3 worden de resultaten van de regressieanalyses vermeld. Daarbij worden de Beta's en nulde orde correlaties vermeld alsmede het percentage verklaarde variantie. Op het eerste meetmoment verklaren de onafhankelijke variabelen samen $18 \%$ van de variantie. Op het derde meetmoment verklaren ze $16 \%$ van de variantie.

Uit de Beta-coëfficiënten blijkt dat kwaliteit van leven op het eerste meetmoment vooral kan worden verklaard uit de variabelen ernst van de ziekte en taakovereenstemming. Naarmate patiënten ernstiger ziek zijn, ervaren zij een lagere kwaliteit van leven. Een relatief lage kwaliteit van leven gaat samen met veel takovereenstemming tussen huisarts en specialist. Daarnaast blijkt er een tendens te zijn dat een lage kwaliteit van leven samengaat met relatief weinig emotionele steun en relatief veel praktische steun.

Op het derde meetmoment blijkt een relatief lage kwaliteit van leven eveneens samenhang te vertonen met de ernst van de ziekte en met het aantal professionele zorgverleners. Ook bij de derde meting bestaat een niet significante relatie tussen 
emotionele c.q. praktische steun en kwaliteit van leven, die consistent is met de eerste meting.

Tabel 9.3 Resultaten regressie-analyse determinanten van 'kwaliteit van leven', $\mathbf{t 1}, \mathrm{t} 3$ $(n=51)$

$\mathrm{t} 1$

ernst $\mathrm{t} 1$

leeftijd

aantal prof. zorgverleners $\mathrm{t} 1$

takovereenstemming $\mathrm{t} 1$

tevredenheid zorg $\mathrm{t} 1$

overeenstemming zorgbehoeften $\mathrm{t} 1$

emotionele steun $\mathbf{t} 1$

praktische steun $\mathrm{t} 1$

$R^{2}=.31(\operatorname{adj} .18)$

t3

ernst t 1

leeftiid

aantal prof. zorgverleners $t 3$

tevredenheid zorg 13

overeenstemming zorgbehoeften t3

emotionele steun $\mathbf{t} 3$

praktische steun t3

$\mathrm{R}^{2}=.28($ adj. 16$)$

$\cdot p<0.10, \cdots p<0.05$ kwaliteit van leven

B

$\begin{array}{rc}-.36 & -.25^{*} \\ .03 & .02 \\ .10 & .06 \\ -.22 & -.22 \\ .29 & .20 \\ .14 & .18 \\ .27 & .23 \\ -.10 & -.22\end{array}$

kwaliteit van leven

$r \quad B$

$\begin{array}{ll}-.23 & -.26^{*} \\ -.13 & -.13 \\ -.36 & -.32 * * \\ .00 & -.11 \\ .19 & .16 \\ .08 & .23 \\ -.17 & -.22\end{array}$

De gevonden relatie tussen ernst van de ziekte en kwaliteit van leven komt overeen met onze verwachting. Uitgaande van de literatuur die in hoofdstuk 2 is beschreven, verwachten we dat naarmate de objectieve ernst van de ziekte groter is, dat wil zeggen wanneer er is sprake van metastasering en een slechte prognose, de kwaliteit van leven slechter is (De Haes, 1988; Linssen, 1979; Priestman, 1981). De negatieve correlatie tussen takovereenstemming en kwaliteit van leven is tegengesteld aan de door ons verwachte samenhang. Taakovereenstemming zou volgens ons kunnen leiden tot beter afgestemde zorg die de kwaliteit van leven positief beïnvloedt (zie hoofdstuk 2). De gevonden relatie, in tegengestelde richting, zou verklaard kunnen worden vanuit de gedachte dat als patiënten er daadwerkelijk slecht aan toe zijn, dat wil zeggen slecht functioneren, veel klachten hebben en ontevreden zijn over hun leven, de coördinatie van zorg vanzelf op gang komt en de betrokken zorgverleners beter weten wat hen te doen staat. Of anders gezegd, oorzaak en gevolg kunnen worden omgedraaid: taak- 
overeenstemming leidt niet tot een slechtere kwaliteit van leven, maar een slechtere kwaliteit van leven leidt tot meer taakovereenstemming.

In veel onderzoeken (Dunkel-Schetter, 1984; Funch, 1982; Meyerowitz,1980; Spiegel, 1984; Bloom, 1982) blijkt een positieve correlatie tussen emotionele steun en kwaliteit van leven te bestaan. De positieve samenhang wordt in ons onderzoek ook gevonden maar blijkt echter niet significant te zijn $(p=0.11)$. Blijkbaar is bij deze patiënten-categorie de ernst van de ziekte de belangrijkste determinant van kwaliteit van leven. De betekenis van andere variabelen wordt daardoor overheerst. De gevonden tendens (de positieve correlatie tussen emotionele steun en kwaliteit van leven) zou geïnterpreteerd kunnen worden als een causale relatie waarbij meer emotionele steun een beter welbevinden en functioneren veroorzaakt. Anderzijds is het mogelijk dat de gezondheidstoestand de hoeveelheid steun beïnvloedt: ernstig ziek-zijn kan leiden tot minder emotionele steun (Ros, 1990, Dunkel-Schetter, 1982).

In tegenstelling tot emotionele steun wordt er tussen praktische steun en kwaliteit van leven een consistente negatieve samenhang gevonden $(p=0.12)$. Het is onwaarschijnlijk dat veel ervaren praktische steun leidt tot een lagere kwaliteit van leven. Andersom kan worden beredeneerd dat een lagere kwaliteit van leven leidt tot meer praktische steun, simpelweg omdat de patiënt ook meer praktische steun nodig heeft. Het wordt duidelijk dat we over de relatie tussen 'sociale steun' en kwaliteit van leven geen uitspraken kunnen doen zonder de verschillende vormen van sociale steun te onderscheiden.

De positieve samenhang tussen het aantal zorgverleners en kwaliteit van leven bij het derde meetmoment komt overeen met onze verwachtingen. De voor de hand liggende verklaring hiervoor is dat een lagere kwaliteit van leven tot meer behoefte aan professionele zorg leidt.

$\mathrm{Bij}$ het eerste meetmoment is er geen relatie gevonden tussen het aantal professionele zorgverleners en kwaliteit van leven. Dit kan verklaard worden door de scheve verdeling met betrekking tot het aantal contacten. De meeste patiënten hadden bij de eerste meting net de ziekenhuisopname en de behandeling achter de rug zodat de meerderheid van de patiënten met veel zorgverleners contact heeft gehad, ongeacht de ernst van de ziekte of de kwaliteit van leven. Er is dus weinig variatie in het aantal professionele zorgverleners, waardoor een samenhang niet kan worden gevonden. Bij het derde meetmoment is er meer variatie in het aantal contacten met professionals. Patiënten met een lagere kwaliteit van leven onderscheiden zich van mensen met een positievere beoordeling van kwaliteit van leven door een groter aantal contacten met professionele zorgverleners.

Aan de hand van deze resultaten zijn de verschillende determinanten van kwaliteit van leven in een model (figuur 9.1) geplaatst. Daarbij werden variabelen gebruikt die een significante bijdrage leveren aan de verklaarde variantie en variabelen (emotionele steun en praktische steun) die een consistente samenhang vertonen met kwaliteit van leven en in de regressieanalyses relatief hoge Beta-waarden hebben. 


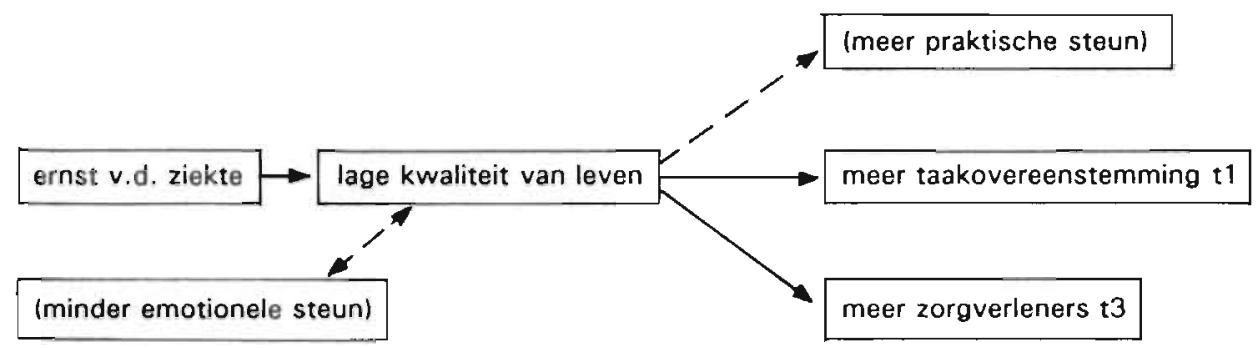

In hoofdstuk 5 is besloten de vier afzonderlijke maten van kwaliteit samen te voegen op grond van hun onderlinge samenhang. Om na te gaan of door die samenvoeging bepaalde verbanden over het hoofd zijn gezien, zijn nulde orde correlaties berekend tussen de geselecteerde onafhankelijke variabelen en disfunctioneren, psychische klachten, lichamelijke klachten en globaal onwelbevinden. In de onderstaande tabel wordt duidelijk welke relaties gevonden zijn. Alleen de significante correlaties $(p<0.10)$ zijn weergegeven.

Tabel 9.4 De relaties tussen de geselecteerde variabelen en de indicatoren voor kwaliteit van leven op $\mathrm{t} 1$ en $\mathrm{t} 3$. Pearson correlaties $(\mathrm{n}=51$ ).

\begin{tabular}{|c|c|c|c|c|c|c|c|c|}
\hline & \multirow{2}{*}{$\begin{array}{l}\text { SIP } \\
t 1\end{array}$} & \multirow[b]{2}{*}{ t3 } & \multicolumn{2}{|c|}{ klachten(lic) } & \multicolumn{2}{|c|}{ klachten(ps) } & \multicolumn{2}{|c|}{ onwelbevinden } \\
\hline & & & $\mathbf{t} 1$ & t3 & t1 & +3 & $\mathrm{t} 1$ & t3 \\
\hline ernst 11 & - & - & .39 & .25 & .24 & - & .51 & .24 \\
\hline leeftijd t1 & .23 & .27 & - & - & - & - & - & - \\
\hline prof.zorgverleners $t 1, t 3$ & . & - & .33 & - & .27 & - & .41 & - \\
\hline over.zorgbehoeften $t 1, t 3$ & - & -.28 & -.21 & - & - & - & - & -.24 \\
\hline taakovereen. $\mathrm{t} 1$ & .24 & - & - & - & .21 & - & - & .35 \\
\hline tevredenheid zorg $t 1, t 3$ & - & - & -.25 & - & -.27 & - & -.39 & - \\
\hline emotionele steun $t 1, t 3$ & - & - & -.42 & - & - & - & -.30 & - \\
\hline praktische steun $t 1, t 3$ & .29 & .32 & - & - & - & - & - & - \\
\hline
\end{tabular}

De gevonden correlaties zijn consistent met de verbanden tussen de geselecteerde onafhankelijke variabelen en de samengestelde maat voor kwaliteit van leven.

\subsection{De longitudinale analyses}

Om na te gaan welke van de onderzochte variabelen, onafhankelijk van elkaar, het onderscheid tussen de groep met een positief beloop van kwaliteit van leven $(n=25)$ en de groep met een negatief/gelijk beloop $(n=26)$ verklaren zijn 
discriminantanalyses uitgevoerd. Eerst is de discriminantanalyse uitgevoerd met de variabelen die op het eerste meetmoment zijn gemeten. Vervolgens is de analyse herhaald met de variabelen zoals ze op het derde meetmoment zijn gemeten.

Met een discriminantanalyse wordt geprobeerd de verschillen tussen deze twee groepen, mogelijk uit te drukken in een gewogen som van variabelen. De groepsgemiddelden van die gewogen som moeten zoveel mogelijk van elkaar verschillen in verhouding tot verschillen van die gewogen som binnen de groepen. Met andere woorden: bij een discriminantanalyse wordt berekend op welke manier de variabelen gecombineerd moeten worden om een maximaal discriminerend effect tussen de groepen te bereiken. De analyses zijn stapsgewijs uitgevoerd, waarbij de laagste waarde van Wilks Lambda als selectiecriterium is gebruikt. Hierdoor blijft een gereduceerd aantal variabelen over die het meest discrimineren. De variabele sociaal-economische status is vanwege het suppressor-effect, ook hier weggelaten (zie paragraaf 9.2). De ontbrekende waarden werden vervangen door de gemiddelde scores.

In bijlage K zijn de binnen-groeps structuurcoëfficiënten, de gestandaardiseerde discriminantfunctie coëfficiënten, de canonische correlatie, de eigenwaarde en het percentage juist geclassificeerde gevallen weergegeven, voor de discriminantanalyses op het eerste en op het derde meetmoment.

Om na te gaan hoe robuust deze analyses zijn, hebben we de best discriminerende variabelen van de eerste respectievelijk derde meting samengevoegd in een analyse.

$\mathrm{Na}$ samenvoeging van de best discriminerende variabelen van $\mathrm{tl}$ en $\mathrm{t} 3$ blijven de volgende variabelen over: taakovereenstemming, leeftijd, tevredenheid over zorg $(\mathrm{t} 3)$, het aantal professionals ( $\mathrm{t} 1$ ), emotionele steun ( $\mathrm{B}$ ) en praktische steun ( $\mathrm{t} 1$ ). Van alle gevallen is $76 \%$ juist geclassificeerd. De verklaarde variantie bedraagt $41 \%\left(0.64^{2}\right)$. In tabel 9.5 worden de resultaten van de discriminantanalyse weergegeven.

Uit de gemiddelde scores op de discriminerende variabelen blijkt dat patiënten die een negatief beloop van kwaliteit van leven hebben of patiënten van wie de kwaliteit van leven gelijk is gebleven, ouder zijn, meer contacten hebben met professionele zorgverleners op het eerste meetmoment en tevredener zijn over de zorgverlening op het derde meetmoment, dan patiënten met een positief beloop van kwaliteit van leven. Er bestaat bij patiënten met een negatief beloop bovendien meer taakovereenstemming tussen huisarts en specialist (t1) en zij ervaren minder emotionele ( $\mathrm{t} l$ ) en praktische steun ( $\mathrm{t} 3$ ) vanuit het sociale netwerk dan patiënten met een positief beloop. 
leeftijd

aantal prof.zorgverleners $t 1$

taakovereenstemming

praktische steun $\mathrm{t} 1$

emotionele steun $t 3$

tevredenheid $\mathrm{t} 3$

$\begin{array}{rr}.55 & .30 \\ .47 & .31 \\ .61 & .43 \\ -.31 & .26 \\ -.36 & -.26 \\ .51 & .34\end{array}$

.31

43

.26

45

can correlatie .64 , eigenwaarde .71 , juist geclassificeerd $76 \%$

De gemiddelde scores op de discriminerende variabelen worden in tabel 9.6 weergegeven.

Tabel 9.6 Gemiddelde scores op de discriminerende variabelen bij patiënten die vooruit gaan of patiënten die achteruit gaan/gelijk blijven op kwaliteit van leven. t-test groep $(n=51)$.

negatief beloop /gelijk

$(n=25)$ positief beloop

$(n=25)$ leeftijd

aantal prof.zorgverleners $t 1$

taakovereenstemming $t 1$

praktische steun $\mathbf{t}$

emotionele steun $\mathrm{t} 3$

tevredenheid over de zorg $t 3$

- $P<0.10, \cdots P<0.05$.

63.7
5.3
8.5
2.8
3.6
12.4

3.7
5.3

8.5

2.8

12.4

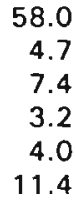

p

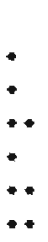

Leeftijd heeft een negatieve samenhang met het beloop van kwaliteit van leven. Ouderen hebben blijkbaar meer kans op een negatief beloop van kwaliteit van leven dan jongeren. Zoals uit tabel 9.2 blijkt hangt leeftijd negatief samen met sociaal-economische status. Dit kan verklaard worden vanuit het feit dat veel oudere patiënten in ons onderzoek alleen een lagere school opleiding hebben afgerond. Het betreft in veel gevallen dus patiënten met een relatief zwakke sociale positie in de maatschappij. Deze bevinding komt overeen met onze verwachtingen die in hoofdstuk 2 zijn omschreven. Patiënten met een zwakke positie hebben waarschijnlijk minder mogelijkheden om effectief met problemen ten gevolge van de ziekte om te gaan dan personen met een sterke sociale positie. Ouderen met een relatief lage opleiding hebben gemiddeld minder kennis over gezondheid en de gezondheidszorg, minder toegang tot informatiebronnen en 
minder vaardigheden om met werkers in de gezondheidszorg te communiceren (Visser, 1988). Met andere woorden, deze patiënten hebben minder mogelijkheden om effectief om te gaan met de gebeurtenissen die hen overkomen.

De groep patiënten met een negatief/gelijk beloop van kwaliteit van leven heeft reeds bij de eerste meting met meer verschillende professionele zorgverleners te maken dan de groep patiënten met een positiever beloop. Dit duidt erop dat al op het eerste moment patiënten veel problemen hebben waarbij ze afhankelijk zijn van professionals.

De grotere tevredenheid over de zorg op $\mathrm{t} 3$ bij de groep met een negatief beloop is niet gemakkelijk te verklaren. Bij de transversale analyses hebben we immers een positief verband tussen kwaliteit van leven en tevredenheid gevonden. Juist omdat de mensen met een negatief beloop meer afhankelijk zijn van professionele zorgverleners, zijn zij waarschijnlijk meer dankbaar voor en tevreden over de zorg die ze ontvangen. Het is echter ook mogelijk dat professionele zorgverleners, juist als het slechter gaat met de patiënt, meer hun best doen om een zo goed mogelijke zorg te leveren.

Dat een negatief beloop samengaat met meer taakovereenstemming tussen huisarts en specialist, is consistent met de bevindingen bij de transversale analyses en op dezelfde manier te verklaren. Als het slechter gaat met patiënten, komt de professionele zorg op gang en vindt er meer coördinatie plaats in de vorm van taakafstemming.

De patiënten met een positief beloop ervaren zowel meer praktische als meer emotionele steun dan de patiënten met een negatief beloop van kwaliteit van leven. Deze bevinding is consistent met onze verwachtingen die in hoofdstuk 2 zijn geformuleerd.

Een verklaring voor deze bevinding zou kunnen zijn dat veel steun vanuit het netwerk het gemakkelijker maakt om problemen ten gevolge van de ziekte op te lossen. Patiënten met een netwerk dat steun biedt hebben wellicht het gevoel nog steeds gewaardeerd te worden en ergens bij te horen. Andersom zou het zo kunnen zijn dat het achteruitgaan van de kwaliteit van leven leidt tot verlies van steun. Enerzijds omdat het voor mensen in de directe omgeving moeilijk kan zijn om om te gaan met iemand die steeds verder achteruit gaat of zieker wordt. Anderzijds kan de patiënt zelf, omdat hij achteruit gaat, minder terug doen voor de mensen in de directe omgeving. De wederkerigheid van de steun wordt kleiner. Dit kan, volgens de in hoofdstuk 2 beschreven ruiltheorie, leiden tot verlies van contacten en tot minder steun (Ormel, 1989, Janssen, 1992).

In figuur 9.2 worden de determinanten van een negatief/gelijk beloop weergegeven. 


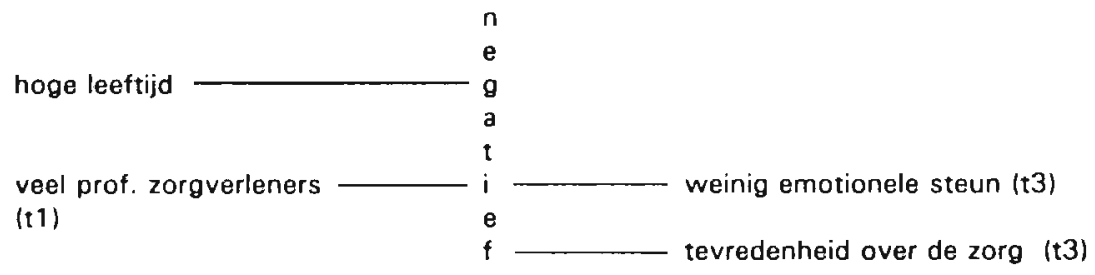

$\begin{array}{ll}\text { veel taakovereenstemming } & \text { b } \\ \text { weinig praktische } & \text { e } \\ \text { steun (t } 1) & 0 \\ & 0 \\ & \text { p }\end{array}$

\subsection{Toepassing van het model op de Maastrichtse groep}

In hoofdstuk 4 hebben we geconcludeerd dat de Maastrichtse onderzoeksgroep ( $\mathrm{n}$ $=16$ ) op een aantal punten significant verschilt van de Noord-Limburgse groep. Doordat de selectie van patiënten in Maastricht anders is verlopen dan in NoordLimburg zien de patiëntengroepen er verschillend uit. De Maastrichtse groep heeft gemiddeld een hogere sociaal-economische status, is jonger en is gemiddeld veel langer ziek dan de patiëntengroep in Noord-Limburg. Bovendien bevat de Maastrichtse groep meer patiënten met metastasen en relatief veel mensen die naast een operatieve behandeling chemotherapie en/of bestraling kregen. Ook de verschillende diagnosegroepen zijn niet gelijk vertegenwoordigd. In hoofdstuk 5 zijn ook wat de afhankelijke variabele (kwaliteit van leven) betreft, verschillen gevonden. Met name op de globale maat voor onwelbevinden en enkele aspecten van het functioneren rapporteert de Maastrichtse groep patiënten een slechtere kwaliteit van leven dan de Noord-Limburgse groep. Besloten is, gezien ook de kleine populatie in Maastricht, om alleen de analyses met betrekking tot NoordLimburg te presenteren en Maastricht als vergelijkingsgroep te gebruiken. In deze paragraaf zullen eerst de significante verschillen tussen Noord-Limburg en Maastricht wat de 'zorg-variabelen' betreft worden gepresenteerd. Vervolgens zal worden nagegaan of het gevonden model ook van toepassing is op de Maastrichtse situatie. 


\subsubsection{Continuïteit van de professionele zorgverlening in Maastricht}

Ook in Maastricht hebben patiënten met veel verschillende zorgverleners contact, zijn er tussen die zorgverleners weinig onderlinge contacten en is er nauwelijks overeenstemming over verantwoordelijkheid bij taken. De patiënten in Maastricht hebben op de eerste meting gemiddeld met minder verschillende zorgverleners contact (gem. 4.2), dan de patiënten in Noord-Limburg (gem. 6.0).

Dit verschil is waarschijnlijk te verklaren vanuit het feit dat alle patiënten in Noord-Limburg zich bij de eerste meting aan het begin van het ziekteproces bevonden. Dit betreft een fase waarin diagnostiek, behandeling en ziekenhuisopnamen plaatsvinden. Hierdoor is het waarschijnlijk dat patiënten met veel verschillende zorgverleners te maken krijgen. De Maastrichtse groep bevat enkele patienten die reeds langer dan een jaar ziek zijn. Bij deze patiënten heeft de afname in het aantal zorgverleners waarschijnlijk al eerder plaatsgevonden. Opvallend is dat in Maastricht geen enkele patiënt contact heeft gehad met een wijkverpleegkundige. Bovendien hebben in deze regio relatief weinig patiënten contact met hun huisarts.

Ten aanzien van het tijdsaspect is een significant verschil gevonden tussen NoordLimburg en Maastricht. In slechts $40 \%$ van de gevallen in Maastricht heeft de huisarts een bezoek afgelegd na ontslag uit het ziekenhuis, terwijl in NoordLimburg $88 \%$ bezoek heeft gekregen van de huisarts en/of wijkverpleegkundige. Een verklaring hiervoor is wellicht dat als patiënten zich reeds lange tijd in het 'ziekenhuis-circuit' bevinden, zoals in Maastricht vaak het geval is, de huisarts minder bemoeienis met de patiënt heeft dan in het begin van het ziekteproces.

Ten aanzien van de tevredenheid over de zorgverlening zijn er enkele significante verschillen met Noord-Limburg. Patiënten in Maastricht zijn op het derde meetmoment significant minder tevreden over de totale zorgverlening en gedurende de hele onderzoeksperiode minder tevreden over de huisarts. Een aantal patiënten in Maastricht bevindt zich in een latere fase van het ziekteproces. Enkele patiënten zijn immers al langer dan een jaar ziek. Bovendien is bij de meerderheid van de patiënten in Maastricht sprake van 'actieve' ziekte, terwijl veel patiënten in Noord-Limburg na verloop van tijd 'ziektevrij' zijn. Het zou zo kunnen zijn dat de patiënten in Maastricht het gevoel hebben dat de gezondheidszorg niets meer voor hen kan doen, dat ze uitbehandeld zijn. De grotere ontevredenheid over de huisarts zou verklaard kunnen worden door het gegeven dat in Maastricht minder huisartsen contacten onderhouden met hun patiënt dan in Noord-Limburg.

\subsubsection{Sociale steun bij patiënten in Maastricht}

Ook ten aanzien van de structurele- en doelstellingskenmerken van sociale steun zijn enkele significante verschillen met Noord-Limburg gevonden. Op het eerste meetmoment is de gemiddelde netwerkgrootte (6.7) kleiner dan in Noord- Limburg (8.5). Maastrichtse patiënten zijn gemiddeld al langer ziek, waardoor het verwachte verlies van contacten waarschijnlijk al eerder is opgetreden. Voorts 
hebben in Maastricht minder mensen een zeer dicht netwerk (40\%) dan in NoordLimburg (69\%).

Verschillen met betrekking tot de doelstellingskenmerken van sociale steun zijn gevonden bij wederkerigheid van de steun. De patiënten in Maastricht blijken gemiddeld meer praktische steun te krijgen dan dat ze zelf geven. Dit kan verklaard worden vanuit het feit dat de patiënten in Maastricht gemiddeld een slechtere kwaliteit van leven hebben dan de patiënten in Noord-Limburg, waardoor zij wellicht minder in staat zijn om netwerkleden in praktische zin te helpen. Dit zou overeen komen met resultaten van het onderzoek van Janssen (1992), waaruit blijkt dat disfunctioneren door ziekte, de wederkerigheid van de praktische steun meer aantast dan de wederkerigheid van de emotionele steun.

\subsubsection{Toepassing van het voor de Noord-Limburgse groep ontwikkelde model}

Omdat het gaat om een klein aantal respondenten zijn geen multivariate technieken gebruikt maar zijn op de eerste plaats correlaties berekend tussen de onafhankelijke variabelen die in dit hoofdstuk zijn geselecteerd en de kwaliteit van leven van patiënten uit Maastricht. Mede vanwege het kleine aantal respondenten zijn weinig correlaties significant. Alleen bij de variabele ernst van de ziekte is een significante negatieve samenhang gevonden met kwaliteit van leven, zowel op het eerste $(r=-.45)$ als op het derde meetmoment $(r=-.46, p<0.10)$. Vanwege de kleine $\mathrm{n}$ is tevens de rangcorrelatie berekend. Ook met behulp van de nonparametrische toets Spearman's rho zijn significante correlaties gevonden tussen ernst en kwaliteit van leven, namelijk -.48 bij de eerste meting en -.53 bij de derde meting.

Vervolgens zijn patiënten met een positief beloop van kwaliteit van leven ( $\mathrm{n}=$ 10) vergeleken met de patiënten met een negatief beloop of weinig verandering in kwaliteit van leven $(n=6)$. Met behulp van $t$-toetsen (en vanwege de kleine aantallen ook met de Mann-Whitney toets) is nagegaan of deze groepen van elkaar verschillen. De patiënten met een negatief beloop blijken significant ouder te zijn dan patiënten met een positief beloop $(p<0.05)$. $\mathrm{Zij}$ hebben bovendien een lagere sociaal-economische status $(p<0.10)$. Deze bevindingen sluiten aan bij de resultaten met betrekking tot de Noord-Limburgse groep. Consistent met de resultaten bij de Noord-Limburgse groep is ook de bevinding ten aanzien van de taakovereenstemming. Bij patiënten met een negatief/gelijk beloop bestaat er meer taakovereenstemming tussen de huisarts en de specialist $(p<0.10)$ dan bij patiënten met een positief beloop. Bij de andere variabelen zijn geen significante verschillen gevonden tussen de twee groepen.

\subsection{Samenvatting}

In dit hoofdstuk beschreven we de multivariate analyses die uitgevoerd zijn met de in hoofdstuk 6 tot en met 8 geselecteerde variabelen. Op deze wijze is getracht te onderzoeken welke variabelen een onafhankelijke significante samenhang vertonen met kwaliteit van leven en het beloop daarvan. 
Allereerst is de samenhang tussen de onafhankelijke variabelen beschreven. Vervolgens zijn, om de determinanten van kwaliteit van leven te bepalen, multiple regressie analyses uitgevoerd voor de eerste en derde meting (transversale analyses). Uit deze analyses blijkt dat zowel op het eerste als op het derde meetmoment 'ernst van de ziekte' een belangrijke determinant is van kwaliteit van leven. Naarmate patiënten volgens objectieve maatstaven (stadium, prognose) ernstiger ziek zijn, hebben zij een lagere kwaliteit van leven. Kwaliteit van leven op het eerste meetmoment blijkt bovendien samen te hangen met takovereenstemming tussen huisarts en specialist. Bij patiënten met een relatief lage kwaliteit van leven is er meer taakovereenstemming. Op het derde meetmoment blijkt een lage kwaliteit van leven samen te gaan met meer verschillende professionele zorgverleners. Op beide meetmomenten is dezelfde tendens gevonden; namelijk dat emotionele steun positief gerelateerd is aan kwaliteit van leven en praktische steun negatief.

Deze bevindingen leiden uiteindelijk tot een model van de determinanten en resultanten van kwaliteit van leven:

- naarmate patiënten ernstiger ziek zijn, is de kwaliteit van leven lager.

- een lagere kwaliteit van leven hangt samen met meer professionele zorg.

- $\quad$ er is een negatieve samenhang tussen kwaliteit van leven en overeenstemming over de taken in de zorgverlening.

- $\quad$ er is een tendens dat weinig emotionele steun samengaat met een lagere kwaliteit van leven.

- er is een tendens dat een lagere kwaliteit van leven leidt tot meer praktische steun vanuit het sociale netwerk .

Uit het onderzoek naar de determinanten van het beloop van kwaliteit van leven blijkt dat patiënten met een positief beloop van kwaliteit van leven gemiddeld jonger zijn, met minder professionele zorgverleners te maken hebben op het eerste meetmoment en meer praktische steun hebben ervaren op dat meetmoment dan patiënten met een negatief/gelijk beloop. Bovendien is er bij deze patiënten minder sprake van takkovereenstemming tussen huisarts en specialist. Patiënten met een positief beloop blijken tevens minder tevreden te zijn over de zorg en meer emotionele steun te ervaren op het derde meetmoment.

Tenslotte zijn enkele verschillen tussen de Noord-Limburgse en Maastrichtse groep beschreven en is nagegaan of het gevonden model ook van toepassing is op de Maastrichtse populatie. We hebben ons, gezien het kleine aantal onderzoekseenheden, beperkt tot correlaties en t-toetsen. Op de twee meetmomenten blijkt alleen 'ernst van de ziekte' een significante negatieve samenhang te vertonen met kwaliteit van leven. Ten aanzien van het beloop van kwaliteit van leven kan worden geconcludeerd dat, consistent met de Noord-Limburgse patiëntengroep, patiënten met een negatief/gelijk beloop ouder zijn, een lagere sociaal-economische status hebben en dat er bij deze patiënten meer sprake is van takovereenstemming. Deze resultaten zijn consistent met onze eerdere bevindingen in Noord-Limburg. 
De verbanden tussen het aantal professionele zorgverleners c.q. sociale steun en kwaliteit van leven zijn in de Maastrichtse groep niet gevonden. 


\section{Conclusies en discussie}

In dit hoofdstuk wordt een relatie gelegd tussen de gevonden resultaten, de theoretische overwegingen en de verwachtingen die in hoofdstuk 2 zijn geformuleerd (10.1). De paragrafen $10.2,10.3$ en 10.4 bevatten methodologische kanttekeningen, praktische aanbevelingen en aanbevelingen voor verder onderzoek.

\subsection{Evaluatie van het onderzoek}

De probleemstelling in ons onderzoek betreft de vraag of ervaren kwaliteit van leven en de veranderingen daarin, behalve door ziekte en behandeling ook worden beïnvloed door de mate van continuiteit van de professionele zorgverlening, door sociale steun, sociale positie en beheersingsoriëntatie. Bij het onderzoek naar deze relaties hebben we het onderstaande onderzoeksmodel gehanteerd.

Figuur 10.1 Het oorspronkelijke onderzoeksmodel

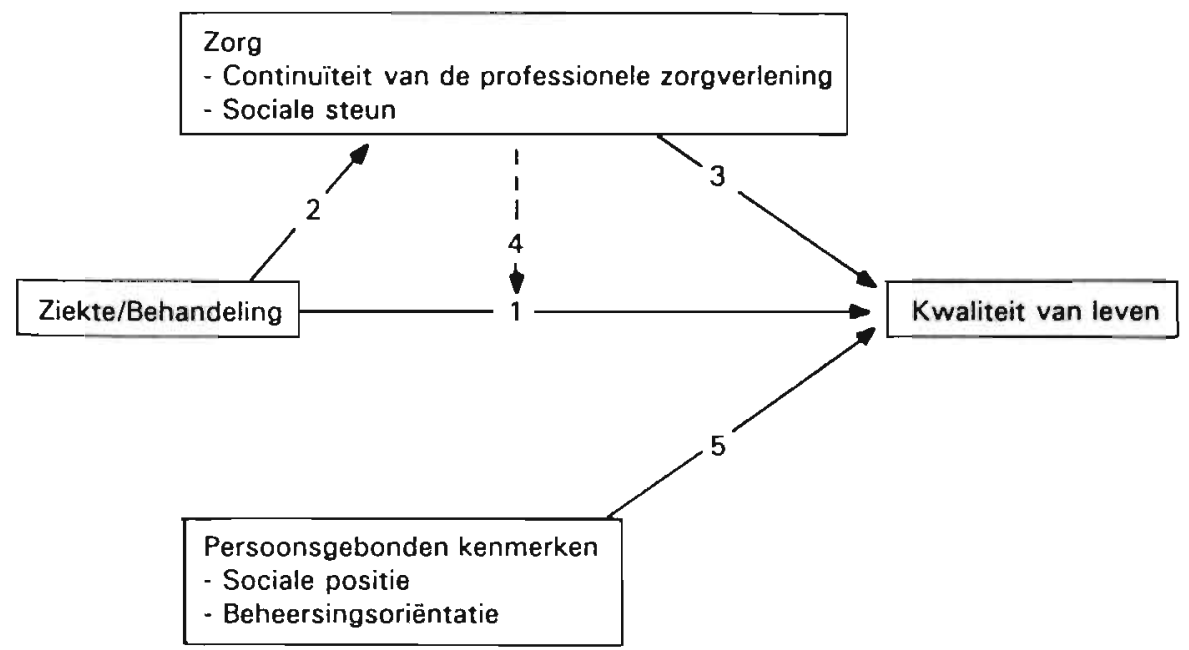


In deze paragraaf worden de onderzoeksresultaten met betrekking tot de in de paragrafen 2.10 geformuleerde vraagstellingen en verwachtingen beschreven. Omdat het onderzoek een explorerend karakter heeft, zijn niet altijd specifieke verwachtingen geformuleerd. Als eerste zal aandacht worden besteed aan de twee vraagstellingen die betrekking hebben op het beschrijvende gedeelte van het onderzoek. Daarna komen de verwachte verbanden tussen enerzijds zorgfactoren, sociale positie en de beheersingsoriëntatie en anderzijds kwaliteit van leven aan bod.

\subsubsection{Kwaliteit van leven}

Verondersteld werd dat voor patiënten in de eerste periode van diagnose en behandeling een crisissituatie ontstaat, waarbij het functioneren en het welbevinden worden aangetast. Patiënten ondergaan vaak belastende behandelingen die lichamelijke en psychische klachten met zich mee kunnen brengen en mensen kunnen beperken in het functioneren. Daarnaast kan de plotselinge confrontatie met de mogelijkheid dood te gaan, leiden tot angst, onzekerheid en andere problemen. Verwacht werd dat er na verloop van tijd weer een zeker evenwicht en een verbetering ontstaat. Enerzijds omdat mensen een zeker aanpassings- en probleemoplossend vermogen hebben, anderzijds omdat de effecten van de ziekte en behandeling waarschijnlijk minder groot worden. Zeker als het gaat om patiënten die een curatief bedoelde behandeling ondergaan en geen tekenen van ziekte meer vertonen verwachtten we een verbetering.

Deze verwachtingen worden door ons onderzoek ondersteund:

In het algemeen blijkt de kwaliteit van leven op een aantal aspecten aangetast te zijn bij het eerste meetmoment. De meeste beperkingen in het functioneren zijn gevonden bij huishoudelijke activiteiten, recreatie en vrije tijd, slapen en mobiliteit. Bovendien bestaan bij veel patiënten klachten over moeheid, pijnlijke spieren, zenuwachtigheid, gespannen zijn en slapeloosheid. Na verloop van tijd treedt er gemiddeld een verbetering op in het functioneren en een vermindering van de klachten. Toch blijven er tijdens de vervolgmetingen nog duidelijke beperkingen in het functioneren en klachten bestaan.

Het globale oordeel over het leven is bij de eerste meting gemiddeld positief (men is tevreden en voelt zich goed) en dat blijft gemiddeld zo. Dit aspect wordt kennelijk minder beïnvloed door ziekte en behandeling. Mogelijkerwijs wordt het globale oordeel gekleurd door het aanpassingsvermogen dat mensen hebben (De Haes, 1988). Het is ook mogelijk dat patiënten bij het globale oordeel over hun leven andere factoren laten meewegen die niet direct met het ziek-zijn te maken hebben, zoals bijvoorbeeld het hebben van een goede relatie met de partner en/of kinderen, de financiële- of werksituatie en het hebben van vrienden.

Vanuit theoretische overwegingen hadden we overigens verwacht dat er een onderscheid kan worden gemaakt tussen gevolgen van de ziekte op het dagelijkse functioneren van mensen, ofwel het sickness aspect, en het belevingsaspect van ziek-zijn (illness). Uit de principale componentenanalyse in dit onderzoek blijkt 
echter dat deze aspecten hoog laden op eén factor. Blijkbaar hangen beide aspecten sterk met elkaar samen.

Op individueel niveau zijn de veranderingen bekeken aan de hand van de verschilscores (t1-t3) op de vier maten voor kwaliteit van leven en is de stabiliteit van de scores onderzocht. In Noord-Limburg gaan 25 patiënten op drie of vier maten van kwaliteit van leven vooruit, tien patiënten blijven ongeveer gelijk scoren en zestien patiënten gaan achteruit. In Maastricht gaan tien patiënten vooruit, vier blijven ongeveer gelijk scoren en gaan twee patiënten achteruit.

\subsubsection{De mate van continuïteit van de professionele zorgverlening}

Ten aanzien van de continuïteit van de zorgverlening en de veranderingen daarvan zijn geen specifieke verwachtingen geformuleerd. Wel zijn we er van uit gegaan dat kankerpatiënten in het algemeen veel en langdurig contacten hebben met de gezondheidszorg en daardoor te maken krijgen met de constellatie van problemen die in paragraaf 2.5 zijn beschreven. Gebleken is dat er inderdaad een aantal knelpunten bestaat in de continuïteit van de zorgverlening.

\subsubsection{Structureel aspect}

- Patiënten ontvangen gemiddeld van zes verschillende professionals zorg, bij de eerste meting en een jaar later van gemiddeld twee zorgverleners.

Uit theoretisch oogpunt hadden we verwacht dat de zorg voor kankerpatiënten niet alleen zou bestaan uit zorg die gericht is op behandelingsbehoefte (gericht op genezing, regulering en verlichting van de aandoening) (Philipsen, 1992). Bij patiënten met een ernstige ziekte zoals kanker worden ook zorgaspecten van belang geacht die gericht zijn op de verzorgingsbehoefte (het aanvullen van tekorten in het vermogen om voor zichzelf te zorgen), ondersteuningsbehoefte (het bijdragen tot het leren omgaan met de ziekte) en mede-lijbehoefte (erbij zijn als iemand lijdt in het kader van een gezondheidsprobleem). Uit dit onderzoek blijkt echter dat er veel meer gebruik wordt gemaakt van professionele zorgverleners wiens voornaamste taak die van 'behandeling' is, namelijk medici, dan van professionele zorgverleners die meer gericht zijn op de verzorgings-, ondersteunings- en mee-lijbehoeften van de patiënt, zoals bijvoorbeeld wijkverpleegkundigen, maatschappelijke werkers en psychologen.

- Er blijken weinig onderlinge contacten tussen de zorgverleners te bestaan. De contacten die tussen (voornamelijk) huisarts en specialist bestaan, vinden plaats in de eerste fase van het ziek-zijn, na afronding van de diagnose en de behandeling. In de fase waarin er niet meer wordt behandeld en patiënten alleen nog op controle komen bij de specialist, vinden er nauwelijks onderlinge contacten plaats.

\subsubsection{Cultureel aspect}

Taakovereenstemming bestaat in het algemeen alleen over het begeleiden van gezinsleden en het coördineren van de zorg. Huisartsen en specialisten vinden dat 
een taak voor de huisarts. Begeleiding van de patiënt en het geven van voorlichting zijn taken waar weinig overeenstemming over bestaat. De verwachting is dan ook dat over deze zorgaspecten weinig afstemming is van de zorg. In dit verband zijn er twee mogelijkheden: of meerdere professionals houden zich met deze taken bezig en zij zijn gezien het geringe aantal onderlinge contacten niet op de hoogte van wat andere zorgverleners bieden, of niemand neemt deze taken voor zijn verantwoording.

\subsubsection{Tijdsaspect}

- De meeste patiënten hebben tijdens de gehele onderzoeksperiode te maken met én specialist; veertig procent heeft echter met meer dan één behandelaars te maken. Het hebben van slechts éen specialist blijkt positief te correleren met de tevredenheid over de zorg. Naar mate mensen ernstiger ziek zijn hebben ze vaker met meer dan één behandelaar te maken.

- Over nazorg kan worden geconcludeerd dat de meeste nieuw gediagnostiseerde patiënten bezoek krijgen van de huisarts en/of wijkverpleegkundige. Als de patiënten al langer klinisch worden behandeld of sprake is van heropnamen zoals bij patiënten in Maastricht het geval is, blijken deze bezoeken na ontslag niet meer zo vanzelfsprekend te zijn en minder vaak voor te komen.

De contacten met de huisarts nemen gemiddeld na verloop van tijd af. Het blijkt overigens dat het aantal contacten met de huisarts op de verschillende meetmomenten samenhangt met de tevredenheid over de zorg van de huisarts. Contacten tussen de huisarts en de patiënt blijken vaak plaats te vinden op initiatief van de patient zelf. De huisarts komt veelal op afroep in actie. Dit wijst op, wat men zou kunnen noemen, 'loketgeneeskunde': de gezondheidszorg reageert pas als de patiënt zich meldt. Professionele zorgverleners zijn veelal gericht op een beperkt aantal problematische momenten in het ziekteproces. Het volgen van de zieke en zijn naasten alsmede het kennen van de voorgeschiedenis en de leefwereld van de patiënt worden daardoor bemoeilijkt.

De rol van de wijkverpleegkundige is bij de onderzoeksgroep niet groot. Van de totale patiëntengroep in Noord-Limburg heeft $22 \%$ contact gehad met een wijkverpleegkundige na het ontslag uit het ziekenhuis. Slechts enkele patiënten hebben gedurende de gehele onderzoeksperiode contact met een wijkverpleegkundige. Dit is wellicht te verklaren vanuit de relatief gunstige toestand waarin de patiënten zich bevinden. Het is waarschijnlijk dat als patiënten in een terminale fase komen, de rol van de wijkverpleging groter wordt. Uit onderzoek van Gondrie e.a. (1987) blijkt dat in het eerste jaar na de diagnose kanker $40 \%$ van de patiënten een beroep doet op de kruisvereniging. Van de terminale patiënten is echter $66 \%$ bij de wijkverpleging bekend. Een andere mogelijke verklaring, voor het vaak ontbreken van de wijkverpleegkundige in het zorgproces, is op de eerste plaats het algemene probleem dat overdracht van zorg van de tweede naar de eerste lijn en vice versa nog steeds niet vlekkeloos verloopt. Ten tweede zijn patienten, maar ook professionele zorgverleners niet altijd op de hoogte van de 
mogelijkheden van andere disciplines, waardoor zij niet worden ingeschakeld bij de zorg (o.a Brasker, 1992; Noordhoek, 1986).

\subsubsection{Doe/stellingsaspect}

- Ondanks het feit dat patiënten en centrale verzorgers een aantal specifieke onderdelen van de zorgverlening, zoals de informatie, diagnosegesprekken en de bejegening negatief beoordelen, zijn patiënten en centrale verzorgers in het algemeen tevreden over de zorgverlening. Dit positieve beeld kan vertekend zijn door selectiebias. Het betreft in ons onderzoek immers een positieve selectie van patiënten met gemiddeld een gunstige prognose. Daarnaast zijn patiënten gemiddeld laag opgeleid. Tevredenheid over de zorg blijkt negatief samen te hangen met de ernst van de ziekte en met de sociaal-economische status van patiënten. De tevredenheidscores zullen daardoor relatief positief zijn vertekend. De tevredenheid over de zorgverlening neemt significant af na verloop van tijd, met name bij patiënten met een gunstig beloop van kwaliteit van leven. Dit kan mogelijk verklaard worden door de afnemende contacten met de zorgverleners.

- Tussen de meningen van huisarts en patiënt blijken wat de zorgbehoeften bij huishoudelijke activiteiten en ziekteverwerking betreft, discrepanties te bestaan. Dit is consistent met bevindingen in de literatuur (Nehemkis e.a., 1984; Patrick e.a., 1982; Jennings, 1981). Bovendien blijkt dat de overeenstemming die wordt gevonden, voor een deel op toeval berust.

Deze bevindingen maken duidelijk dat er inderdaad problemen zijn in de professionele zorgverlening voor deze patiëntencategorie. Deze kunnen als volgt worden samengevat: er is sprake van fragmentatie van de zorg (veel zorgverleners, weinig onderlinge contacten, de patiënt niet kunnen volgen in zijn ziekteproces) en culturele discontinuïteit (weinig overeenstemming over taken in de zorg). Voorts zijn er aanwijzingen dat bejegeningsaspecten in de gezondheidszorg knelpunten vormen (klachten over aandacht, informatievoorziening, bejegening en diagnosegesprekken en de discrepantie tussen de beoordeling van de zorgbehoeften volgens professionals en patiënten).

Continuïteit van de zorgverlening lijkt eerder af dan toe te nemen na verloop van tijd; er zijn minder onderlinge contacten tussen zorgverleners, minder contacten met zorgverleners in de eerste lijn, de tevredenheid over de zorg neemt af en naarmate de diagnose langer geleden gesteld is, is de overeenstemming tussen huisartsen en patiënten met betrekking tot zorgbehoeften minder.

\subsubsection{Sociale steun}

Verwacht werd dat de grootte van het sociale netwerk en de hoeveelheid emotionele en praktische steun na verloop van tijd afneemt en dat de wederkerigheid van de steun wordt aangetast.

De verwachting dat de gemiddelde netwerkgrootte en de ervaren emotionele steun afneemt wordt inderdaad ondersteund: 
- Gemiddeld neemt de netwerkgrootte bij de nieuw gediagnostiseerde patiënten in Noord-Limburg significant. af. Bij patiënten in Maastricht zijn de netwerken al kleiner en nemen niet meer verder af, waarschijnlijk omdat deze patiënten gemiddeld al langer ziek zijn en daardoor een aantal contacten al verloren hebben.

- Ook de ervaren emotionele steun neemt af na verloop van tijd bij patiënten in Noord-Limburg. Dit is in overeenstemming met de resultaten uit ander onderzoek bijvoorbeeld dat van Ros (1990) en suggesties uit de literatuur (Wortman, 1984; De Swaan, 1982).

- In tegenstelling tot onze verwachting blijkt de hoeveelheid ervaren praktische steun in de loop der tijd niet af te nemen.

- De wederkerighcid van de steun blijkt wat emotionele steun betreft, niet sterk te zijn aangetast. Patiënten geven in totaal ongeveer evenveel steun als ze krijgen vanuit het sociale netwerk. Bij patiënten met een relatief slechte kwaliteit van leven, zoals de patiënten in Maastricht, blijkt de wederkerigheid van de praktische steun wel aangetast te zijn. Deze patiënten krijgen meer steun dan dat ze zelf geven. Deze bevindingen zijn in overeenstemming met de resultaten van het onderzoek van Janssen (1992).

\subsubsection{Ziektekenmerken en kwaliteit van leven}

Verwacht werd, dat naarmate de ziekte ernstiger is, de kwaliteit van leven slechter is en het beloop negatiever. Deze verwachting wordt gedeeltelijk ondersteund.

- De ernst van de ziekte, die wordt bepaald door het oordeel van huisarts en specialist over de overlevingsprognose en het stadium van de ziekte, blijkt bij de transversale multivariate analyses inderdaad een belangrijke determinant van kwaliteit van leven te zijn. Zowel op het eerste als op het derde meetmoment rapporteren patiënten die 'ernstig' ziek zijn een slechtere kwaliteit van leven.

- De ernst van de ziekte, zoals gemeten op het eerste meetmoment, blijkt echter niet van invloed te zijn op het beloop van kwaliteit van leven.

Bij het bestuderen van de relatie tussen diagnose- en behandelingsgroepen en kwaliteit van leven deed zich het probleem voor dat het onderzoek betrekking heeft op een kleine, heterogeen samengestelde populatie. Daardoor zijn nauwelijks verschillen gevonden tussen de verschillende diagnose- en behandelingsgroepen.

Tussen de ziekteduur en kwaliteit van leven zijn geen verbanden gevonden. Dit is verklaarbaar vanuit het feit dat er te weinig differentiatie is in de tijdsduur sinds de diagnose. Bij de meeste patiënten is immers ongeveer drie tot vier maanden voor de eerste meting de diagnose kanker gesteld. Patiënten in Maastricht, die gemiddeld al langer ziek zijn en waarbij soms sprake is van 'recurrent disease' rapporteren in het algemeen een lagere kwaliteit van leven dan de nieuwe patiënten. 


\subsubsection{Sociale positie en kwaliteit van leven}

In hoofdstuk twee is de verwachting geformuleerd dat sekse en leeftijd geen invloed zullen hebben op kwaliteit van leven en op het beloop daarvan.

Verwacht werd dat met name de sociaal-economische status en het hebben van een partner wél van invloed zou zijn op de kwaliteit van leven en het beloop daarvan.

Deze verwachtingen worden gedeeltelijk ondersteund:

- Uit dit onderzoek blijkt geen invloed van sekse op kwaliteit van leven. Di invloed van het hebben van een partner hebben we niet kunnen onderzocken vanwege het geringe aantal alleenstaanden, die bovendien op een aantal kenmerken nauwelijks varieerden.

- Bij de transversale analyses is geen relatie gevonden tussen leeftijd en kwaliteit van leven. Wél blijkt leeftijd van invloed te zijn op het beloop van kwaliteit van leven. Jongere patiënten hebben gemiddeld een positiever beloop van kwaliteit van leven dan ouderen.

- $\mathrm{Bij}$ bestudering van de relatie tussen sociaal-economische status en kwaliteit van leven blijkt dat patiënten met een lage sociaal-economische status een negatiever beloop van kwaliteit van leven hebben dan patiënten met een hogere sociaal-economische status. Bij de transversale bivariate analyses is geen verband gevonden tussen sociaal-economische status en kwaliteit van leven. Sociaaleconomisch status blijkt wel belangrijk vanwege de samenhang met leeftijd, taakovereenstemming, tevredenheid over de zorg en ervaren emotionele steun. Een verklaring voor de negatieve samenhang tussen sociaal-economische status en leeftijd is dat veel ouderen alleen een lagere school opleiding hebben. De negatieve relatie tussen sociaal-economische status en tevredenheid over de zorg komt overeen met onderzoek van onder andere Visser (1988), waaruit blijkt dat mensen met een lagere sociaal-economische status minder klachten uiten, minder assertief zijn en zich meer machteloos voelen dan mensen met een hogere sociaaleconomische status. Ook de positieve relatie tussen sociaal-economische status en ervaren steun wordt door literatuur ondersteund. Het is waarschijnlijk dat mensen met een hogere sociaal-economische status meer informatieve en emotionele steun zoeken en krijgen dan mensen met een lagere sociaal-economische status (Oaklcy \& Rajan, 1991; Funch, 1982; Hanson, 1987; Kutner 1987).

Het feit dat patiënten die een negatief beloop van kwaliteit van leven hebben of ongeveer gelijk blijven scoren gemiddeld ouder zijn en een lagere sociaaleconomische status hebben komt overeen met resultaten van het onderzoek van de Witte (1991). De bevindingen kunnen mogelijk verklaard worden vanuit het feit dat jongere, hoog opgeleide mensen vooral meer adequaat gebruik maken van diensten uit de gezondheidszorg, een gezondere leefwijze hebben, meer kennis hebben over de gezondheidszorg, meer toegang hebben tot informatiebronnen en meer vaardigheden hebben om hun weg te vinden in de wereld van de gezondheidszorg (Deleeck, 1988). Daarnaast beschikken zij vaak over meer sociale steun. 
Samengevat luidt de conclusie dat mensen met een sterke sociale positie meer mogelijkheden hebben om met condities ten gevolge van de ziekte om te gaan, dan mensen met een zwakke sociale positie.

\subsubsection{Beheersingsoriëntatie en kwaliteit van leven}

Verwacht werd dat een interne beheersingsoriëntatie een positieve invloed heeft op de kwaliteit van leven en op het beloop diarvan.

Deze verwachting wordt niet ondersteund door dit onderzoek: er is geen enkel verband gevonden tussen de beheersingsoriëntatie en kwaliteit van leven of het beloop daarvan. In paragraaf 10.3 wordt hier verder op ingegaan.

\subsubsection{Continuïteit van de zorgverlening en kwaliteit van leven}

In hoofdstuk 2 is de verwachting geformuleerd dat patiënten bij wie meer sprake is van continuïteit van zorg, een betere kwaliteit van leven hebben en een positiever beloop van kwaliteit van leven dan patiënten bij wie weinig continuïteit van de zorgverlening bestaat. Deze verwachting wordt maar zeer ten dele bevestigd.

- Slechts drie indicatoren vertonen een significante samenhang met kwaliteit van leven: het aantal professionele zorgverleners, de taakovereenstemming tussen huisarts en specialist en de tevredenheid over de zorgverlening.

- Bij de transversale multivariate analyses blijkt een lagere kwaliteit van leven samen te hangen met meer taakovereenstemming en meer professionele zorgverleners. Opvallend is dat deze variabelen wél samenhangen met kwaliteit van leven maar nauwelijks met de ernst van de ziekte. Het inschakelen van professionele zorg en de taakovereenstemming tussen deze professionals wordt waarschijnlijk meer beïnvloed door hoe de patiënt zich voelt en hoe hij functioneert dan door de objectieve ernst van de ziekte.

- Uit de longitudinale analyses bleek een 'negatief/gelijk' beloop van kwaliteit van leven verband te houden met meer taakovereenstemming en meer zorgverleners. De transversale en longitudinale analyses leiden in deze dus tot consistente resultaten. Daarbij is het aannemelijk dat een groter aantal zorgverleners en meer takovereenstemming eerder gevolgen dan oorzaken van een verminderde kwaliteit van leven zijn.

- De richting van het verband tussen tevredenheid over de zorg en kwaliteit van leven is minder duidelijk. Gebleken is dat patiënten die minder ernstig ziek zijn volgens de objectieve maatstaven, tevredener zijn over de zorg. Consistent hiermee is de bevinding dat op het eerste meetmoment tevredenheid positief correleert met kwaliteit van leven. Uit de longitudinale analyses blijkt echter dat patiënten met een positief beloop van kwaliteit van leven op het derde meetmoment ontevredener zijn over de zorg, dan patiënten met een negatief beloop. Bij patiënten met een positief beloop nam de tevredenheid sterker af in de loop der tijd en was de stabiliteit van de scores op tevredenheid minder groot dan bij patiënten met een 'negatief/gelijk' beloop. Een verklaring voor de negatieve relatie tussen het beloop van kwaliteit van leven en tevredenheid is wellicht dat mensen met een 'negatief/gelijk' beloop zeer afhankelijk worden van de professi- 
onele zorg en daardoor dankbaar zijn. Dit laatste komt overeen met resultaten van onderzoek van Visser (1984). Anderzijds is het natuuriijk heel goed mogelijk dat, als patiënten achteruit gaan professionele zorgverleners meer zorg bieden.

- Een buffereffect van continuïteit van de zorgverlening kan niet worden aangetoond.

Dat er zo weinig verbanden zijn tussen continuiteit van de zorgverlening en kwaliteit van leven kan op de volgende wijze worden verklaard:

1. Er blijken problemen te bestaan op alle onderscheiden aspecten van continuitteit van de zorgverlening. Men kan zich zelfs afvragen of continuïteit van de zorgverlening zoals het in dit onderzoek wordt gedefinieerd, in de praktijk vaak voorkomt. Omdat er weinig variatie in de mate van continuitteit van de zorgverlening is, is het vinden van verbanden met kwaliteit van leven problematisch.

2. Een tweede mogelijke verklaring is dat mensen het gebrek aan continuiteit wellicht vanzelfsprekend vinden. Het gezondheidszorgsysteem maakt als het ware deel uit van de leefwereld. Wie ernstig ziek is, onderschikt zich als regel aan het regime van de functionele rationaliteit dat in de gezondheidszorg overheerst. Functionele rationaliteit berust op het kiezen van doeleinden en middelen, die op hun doelmatigheid kunnen worden beoordeeld. In de gezondheidszorg kenmerkt deze vorm van rationaliteit zich in de overheersing van 'cure' boven 'care', handelen volgens procedures, ontwikkeling van biomedische kennis, somatische interpretatie van ziekte en gezondheid en gefragmenteerde zorg. De patiënt is wellicht geneigd om dit regime te accepteren omdat het immers hoop op genezing of verbetering geeft. Met andere woorden de patiënt neemt de fragmentatie en projectmatigheid van de zorg voor lief omdat hij weet dat het vaak de enige manier is om zijn geval te behandelen (Philipsen 1985, 1988).

3 . In ons onderzoek hebben we te maken met een positieve selectie van patiënten van wie de kwaliteit van leven verbetert en het aantal contacten met professionele zorgverleners na verloop van tijd afneemt. De invloed van het systeem van de gezondheidszorg op het leven van de patiënt zal hierdoor ook kleiner worden.

\subsubsection{Sociale steun en kwaliteit van leven}

Verondersteld werd dat naarmate de kwaliteit van leven slechter is, het netwerk van de patiënt kleiner, dichter en minder gevarieerd van samenstelling is. Bovendien hadden we verwacht dat, bij een slechte kwaliteit van leven of een negatief beloop van kwaliteit van leven, de hoeveelheid ervaren emotionele- en praktische steun minder is dan bij een goede kwaliteit van leven en bij een positief beloop.

De verwachtingen met betrekking tot de structurele aspecten van het netwerk worden niet ondersteund:

- Er is geen verband tussen kwaliteit van leven en de grootte, de dichtheid en het percentage familieleden.

Het ontbreken van een verband tussen de dichtheid respectievelijk samenstelling van het netwerk en kwaliteit van leven kan mogelijk worden verklaard door de 
geringe differentiatie in de netwerken. De meerderheid van de patiënten heeft immers een zeer dicht netwerk dat voornamelijk bestaat uit familieleden. Een andere verklaring voor het niet vinden van verbanden is dat niet de structurele maar vooral de functionele kenmerken, zoals kwaliteit en intensiteit van de contacten, van invloed zijn op het functioneren en welbevinden.

De verwachting dat een goede kwaliteit van leven samenhangt met meer sociale steun kan door ons onderzoek gedeeltelijk worden ondersteund. Een onderscheid moet wat dit betreft worden gemaakt tussen emotionele steun en praktische steun.

- Bij de bivariate transversale analyses op het eerste meetmoment is een positief verband gevonden tussen kwaliteit van leven en ervaren emotionele steun. Ook bij de multivariate analyses is eenzelfde tendens gevonden, namelijk dat mensen met een goede kwaliteit van leven meer emotionele steun ervaren. Tevens ervaren mensen met een negatief beloop van kwaliteit van leven minder emotionele steun en een grotere afname van emotionele steun in de loop der tijd.

Het is dus duidelijk dat er een verband bestaat. Wat de richting van het verband is, is moeilijk te zeggen. Het feit dat de objectieve ernst van de ziekte negatief, doch niet significant, samenhangt met emotionele steun zou een aanwijzing kunnen zijn voor de interpretatie dat ernstig ziek-zijn en een slechte kwaliteit van leven leidt tot minder emotionele steun. Dit zou overeen komen met de resultaten van het onderzoek van Ros (1990), waarin is aangetoond dat minder emotionele steun eerder het gevolg dan de oorzaak is van minder welbevinden. Anderzijds kan de omgekeerde richting niet worden uitgesloten. Het is mogelijk dat de richting van het verband beide kanten opgaat. In de literatuur wordt de relatie meestal geïnterpreteerd als een positieve invloed van sociale steun op kwaliteit van leven (o.a. Wortman, 1984; Kutner, 1987; Lin, 1985). Om de richting van het verband te onderzoeken zouden lineair structurele analysetechnieken gebruikt kunnen worden. In ons onderzoek beschikken we echter over te weinig onderzoekseenheden om deze techniek toe te passen.

- Significante verbanden ten aanzien van praktische steun zijn bij de transversale analyses niet gevonden. Wel is de tendens gesignaleerd dat een slechte kwaliteit van leven samengaat met meer praktische steun. De longitudinale analyses laten zien dat een positieve verandering in kwaliteit van leven samenhangt met meer ervaren praktische steun op het eerste meetmoment.

\subsubsection{Ernst van de ziekte in relatie tot kenmerken van zorg}

In hoofdstuk 2 is een vraagstelling geformuleerd met betrekking tot de relatie tussen ziektegerelateerde factoren enerzijds en continuiteit van de zorgverlening en sociale steun anderzijds. Er zijn hierbij geen hypothesen geformuleerd.

Zowel bij de eerste als bij de derde meting is een negatief verband gevonden tussen ernst van de ziekte en de tevredenheid over de zorg. Daarnaast hebben ernstig zieken vaak met meerdere behandelaars te maken. Naarmate de diagnose langer geleden gesteld is, zijn minder professionele zorgverleners bij de zorg betrokken, wordt er minder vaak bezoek na ontslag uit het ziekenhuis gerapporteerd en bestaat er minder overeenstemming tussen huisarts en patiënt als het gaat 
om zorgbehoeften. Tussen de ernst c.q. ziekteduur en sociale steun is geen enkel significant verband gevonden.

\subsubsection{Een herzien onderzoeksmodel}

$\mathrm{Nu}$ we de beschikking hebben over de resultaten van het onderzoek zijn we genoodzaakt om ons onderzoeksmodel bij te stellen.

In figuur 10.2 vatten we de resultaten van het onderzoek samen in de vorm van een herzien onderzoeksmodel. De pijlen moeten worden geïnterpreteerd als de samenhang van het een met het ander. Het gaat dus niet om het aangeven van causaliteit van de relaties. De relaties die zijn weergegeven zullen in vervolgonderzoek getoetst moeten worden.

1. Zowel uit de bivariate als de multivariate analyses is gebleken dat ernst van de ziekte een negatieve invloed heeft op kwaliteit van leven.

2. De relatie tussen sociale steun en kwaliteit van leven heeft waarschijnlijk de aard van een functionele loop: de kwaliteit van leven heeft invloed op de ervaren steun, de ervaren steun beïnloedt de kwaliteit van leven.

3. Het beloop van kwaliteit van leven wordt mede beïnvloed door leeftijd en de sociaal-economische status van de patiënt.

4. Sociaal-economische status is van invloed op de ervaren steun.

5. Sociaal-economische status is van invloed op de taakovereenstemming en tevredenheid van de zorg. Uit de literatuur blijkt bovendien dat sociaal-economische status ook van invloed is op het aantal betrokken professionele zorgverleners.

6. De kwaliteit van leven hangt samen met taakovereenstemming, het aantal betrokken professionele zorgverleners en de tevredenheid over de zorg.

Figuur 10.2 Het herziene onderzoeksmodel.

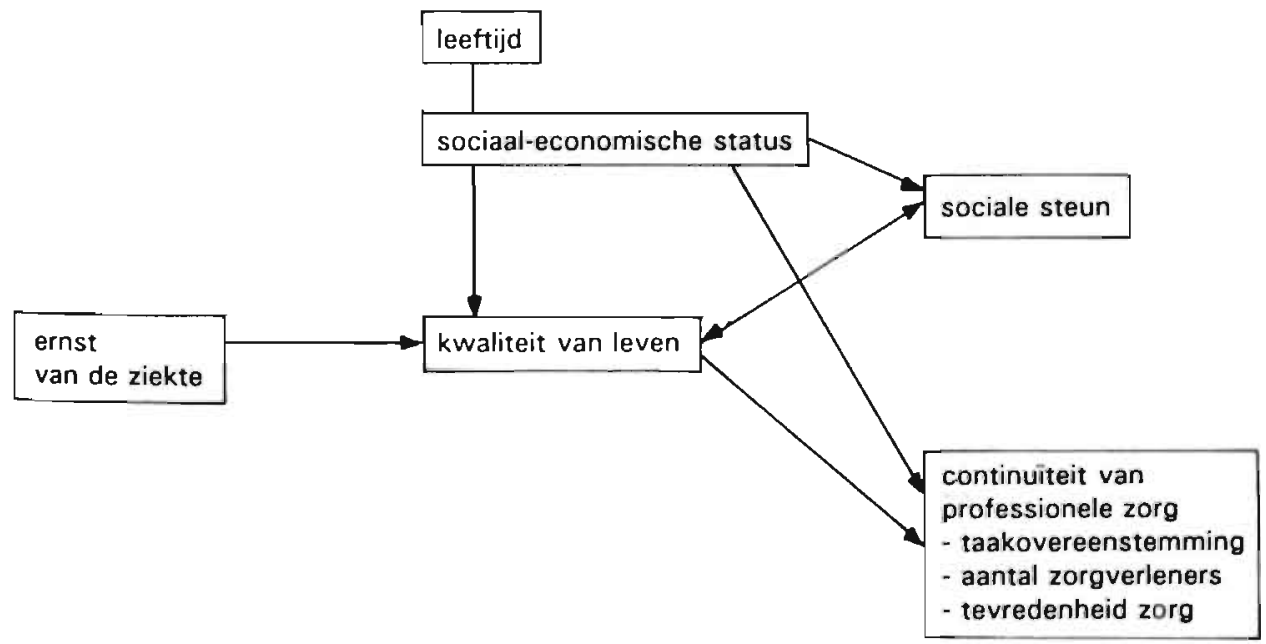




\subsection{Methodologische problemen}

In deze paragraaf worden enkele opmerkingen van methodologische aard gemaakt met betrekking tot de respondenten, de opzet van het onderzoek en de meetinstrumenten.

\subsubsection{De respondenten}

Eén van de problemen in dit onderzoek is de betrekkelijk kleine onderzoeksgroep. De bedoeling was zowel in Noord-limburg als in Maastricht 50 onderzoekseenheden te selecteren. Door de selectieproblemen in Maastricht hebben we hier slechts 38 eenheden kunnen formeren die voor een deel niet aan de inclusiecriteria voldeden.

Daarnaast is er sprake van uitval, dat voor het grootste gedeelte te wijten is aan overlijden en te ziek-zijn van patiënten. Uiteindelijk hielden we een groep over van 51 (nieuw gediagnostiseerde) patiënten in Noord-Limburg en 16 in Maastricht. Door de verschillen tussen deze twee groepen kunnen ze niet worden samengevoegd bij de analyses. Door het kleine aantal patiënten is het bijvoorbeeld niet mogelijk om aparte analyses voor de verschillende diagnose- en behandelingsgroepen uit te voeren en zijn we beperkt in het uitvoeren van multivariate analyses.

Door de non-respons van de medisch specialisten zijn niet alle onderzoekseenheden compleet, waardoor we bij sommige variabelen te maken hebben gekregen met ontbrekende waarden.

Niet alleen het kleine aantal maar ook de kenmerken van de patiënten in de categorie met volledige respons spelen een belangrijke rol. Het gaat immers om een positieve selectie van patiënten, die jonger en minder ernstig ziek zijn dan de groep uitvallers. De positieve selectie van patiënten zorgt hierbij waarschijnlijk voor een zekere selectiebias. Dit kan onder andere consequenties hebben voor de resultaten ten aanzien van kwaliteit van leven. Zo blijkt bijvoorbeeld dat de patienten in de volledige-respons groep gemiddeld vooruit gingen in kwaliteit van leven. Ook is het wellicht zo dat de resultaten met betrekking tot onderlinge contacten tussen zorgverleners, contacten van patiënten met huisartsen en wijkverpleegkundigen en tevredenheid over de zorg, worden beïnvloed door de positieve selectie.

De scores op een aantal belangrijke variabelen van de patiënten die na de eerste meting uitvielen door overlijden/te ziek-zijn $(n=36)$, zijn vergeleken met de scores van de volledige responsgroep van Noord Limburg. De uitvallers blijken gemiddeld significant hoger te scoren op de SIP, dus meer beperkt te zijn in hun functioneren en meer lichamelijke klachten te hebben $(p<0.05)$. Uitvallers verschillen echter niet van de volledige responsgroep wat het globale welbevinden en de psychische klachten betreft. Zij zijn wel ernstiger ziek: 26 van de 36 personen heeft metastasen en de meesten hebben een slechte prognose.

De scores betreffende het aantal professionele zorgverleners, de taakovereenstemming, de hoeveelheid ervaren emotionele en praktische steun verschillen niet 
significant van de scores van de volledige-responsgroep. De groep uitvallers blijkt wél significant minder tevreden te zijn over de zorgverlening en gemiddeld ouder te zijn. Deze laatste twee bevindingen zijn weer consistent met de veronderstellingen in ons model.

Uit de analyses die betrekking hebben op de volledige responsgroep uit Maastricht komen bovendien enkele resultaten die consistent zijn met de resultaten van de groep in Noord-Limburg. Ernst van de ziekte blijkt ook in deze groep negatief te correleren met kwaliteit van leven. Patiënten met een positief beloop van kwaliteit van leven zijn ook bij deze groep significant jonger en zij hebben een hogere sociaal-economische status dan de patiënten die gelijk bleven scoren of achteruit gingen. Tevens is er bij de 'positieve' groep minder taakovereenstemming tussen huisartsen en specialisten.

Op basis hiervan kan niet worden gesteld dat de resultaten van dit onderzoek generaliseerbaar zijn naar alle patiënten met kanker, maar wel dat de gevonden verbanden van toepassing kunnen zijn op anderen dan alleen maar relatief "gezonde patiënten". Het feit dat we te maken hebben met een zeer kleine onderzoekspopulatie in dit onderzoek, is daarom minder problematisch dan in eerste instantie wordt gedacht.

\subsubsection{Opzet van het onderzoek}

De onderzoeksopzet is complex. Het gaat om twee lokaties, drie meetmomenten en verscheidene respondenten per casus.

De longitudinale opzet heeft verschillende voordelen: het is mogelijk om tendensen en veranderingen te belichten, het geeft aanwijzingen voor causaliteit van verbanden en de relaties kunnen bestudeerd worden in de verschillende fasen van het ziekteproces. De beperking hierbij is dat in ons onderzoek patiënten slechts een jaar gevolgd worden. Hierdoor is minder inzicht verkregen in de situatie voor het ziek-zijn, in eventuele terugkeer van de ziekte en in de gevolgen van een terminale fase, dan wenselijk is. Een van de problemen die zijn ontstaan ten gevolge van de complexe opzet is de grote uitval in de patiëntenpopulatie. Dit is een bekend probleem bij longitudinaal onderzoek en wordt hier nog eens versterkt door de noodzaak om meerdere respondenten bij een casus te betrekken. We houden dus relatief weinig onderzoekseenheden over. Nadelen van de longitudinale opzet zijn bovendien, het vinden van verschillende resultaten op verschillende tijdstippen en het feit dat relaties bij de transversale analyses niet altijd consistent zijn met de bevindingen bij de longitudinale analyses. Dit betekent dat bij het formuleren van conclusies enige voorzichtigheid in acht moet worden genomen.

Een probleem dat een rol speelt bij longitudinaal onderzoek is het fenomeen regressie naar het gemiddelde, zoals beschreven werd in paragraaf 5.2. Dit probleem heeft verschillende aspecten. Op de eerste plaats is het een statistisch probleem. Dit betekent dat mensen die extreem scoren (zogenaamde uitbijters) op de eerste meting, gemiddeld minder extreem scoren op een andere meting, en dat onderzoekseenheden die bij de ene meting op of in de buurt van het gemiddelde scoren, bij een andere meting ten dele hoger of lager scoren. Op de tweede plaats 
is er een meetprobleem: iemand die op een 5-puntsschaal 'vijf scoort kan niet hoger scoren bij een vervolgmeting, iemand die 'een' scoort kan niet lager. De voor-of achteruitgang is dus vantevoren ten dele logisch begrensd. Voorts is er nog een psychologisch probleem; mensen zullen geneigd zijn om, wanneer ze de ene keer extreem scoren, de volgende keer minder extreem te scoren. Het regressie-effect doet zich sterker voor naarmate de correlatie tussen de verschillende metingen lager is. De correlaties tussen de verschillende metingen waren wat de afzonderlijke indicatoren voor kwaliteit van leven en de samengestelde score voor kwaliteit van leven betreft tamelijk hoog. Het regressie-effect zal dus in dit onderzoek niet extreem groot zijn.

In paragraaf 5.2. bleek dat er inderdaad een regressie-effect is; de verschilscores in kwaliteit van leven hangen negatief samen met de beginscores op kwaliteit van leven. Het is mogelijk dat dit de resultaten beïnvloedt. Omdat we in dit onderzoek te maken hebben met een kleine populatie is het niet mogelijk om in de multivariate analyses voor dit effect te corrigeren. Het is waarschijnlijk dat de veranderingen in kwaliteit van leven voor een deel ook werkelijke veranderingen zijn, die we, gesteund door ander onderzoek, ook hadden verwacht. Anderzijds zullen de veranderingen gedeeltelijk veroorzaakt worden door de constellatie van statistische en meetproblemen zoals hierboven benoemd.

Een andere opmerking die in dit kader gemaakt moet worden betreft de gehanteerde significantiegrens. Deze werd bij veel analyses op $p=0.10$ gesteld. De motivatie hiervoor is dat het gaat om een explorerend onderzoek met een kleine populatie, dat gericht is op het ontwikkelen van een nieuw model. Bij een significantiegrens van 0.05 zouden wellicht relevante variabelen voor het model worden uitgesloten. We realiseren ons echter dat de toevalskans bij deze grens toeneemt van één op twintig naar én op tien.

\subsubsection{Meetinstrumenten}

Met betrekking tot de meetinstrumenten die gebruikt zijn om kwaliteit van leven te operationaliseren kan worden geconcludeerd dat de globale maten alleen, onvoldoende inzicht bieden om de kwaliteit van leven en de veranderingen daarin te meten. De klachtenlijst voor kankerpatiënten en de SIP leveren meer gedetailleerde informatie op. Deze maten zijn blijkbaar ook sensitief genoeg om veranderingen in de gedragsmatige en belevingsaspecten van kwaliteit van leven te meten.

Om continuïteit van de professionele zorgverlening te meten hebben we gebruik gemaakt van enkele indicatoren. De daadwerkelijke inhoud van de zorg is buiten beschouwing gebleven. Het in kaart brengen van de inhoud van de zorg van professionele zorgverleners door middel van patiëntendagboeken en nauwkeurige registratie van de zorgactiviteiten van de verschillende zorgverleners, zou waarschijnlijk meer inhoudelijke informatie hebben opgeleverd en meer inzicht in de relatie tussen continuïteit van de zorgverlening en kwaliteit van leven. Aan de andere kant kunnen we er van uitgaan dat als de voorwaarden voor inhoudelijke 
overeenstemming, zoals onderlinge contacten en taakafbakening, niet aanwezig zijn, er inhoudelijk waarschijnlijk ook geen afstemming bestaat.

De taakovereenstemming is slechts én keer gemeten, namelijk bij het eerste meetmoment. Helaas zijn we er niet in geslaagd dit aspect op meerdere tijdstippen te meten. Het is mogelijk dat tijdens het ziekteproces bepaalde verantwoordelijkheden verschuiven van de specialist naar de huisarts en dat de taakovereenstemming verandert in de tijd.

Om de kenmerken van het sociale netwerk te meten hebben we gebruik gemaakt van enkele algemene vragen. Bij de grootte van het netwerk hebben we bijvoorbeeld gevraagd naar de namen van alle mensen waar de patiënt contact mee had en die belangrijk waren voor de patiënt. Men zou echter ook de netwerkomvang van verschillende groepen binnen dit algemene netwerk kunnen onderzoeken. Bijvoorbeeld de omvang van het netwerk van mensen waarmee patiënten wekelijks contact hebben, de omvang van het deelnetwerk van personen die dicht in de buurt wonen, de omvang van de deelnetwerken gedifferentieerd naar rollen (kinderen, vrienden, collega's) of de omvang van het netwerk van mensen waarbij wederkerigheid van de steun bestaat etc. Van Sonderen (1989) heeft een methode voor het meten van zulke specifieke maten voor sociale steun uitgewerkt. Het gebruik van meer specifieke maten zou in de toekomst toegepast kunnen worden bij de vragen over emotionele en praktische steun.

Ten slotte nog een opmerking over de gebruikte 'cancer locus of control schaal'. De scores op de subdimensies van deze schaal blijken, tegen de verwachtingen in, geen verband te vertonen met kwaliteit van leven. Dit kan voor een deel het gevolg zijn van het feit dat nogal wat mensen problemen hebben met het invullen van de lijst, omdat ze de vragen niet goed begrijpen. Maar het kan ook veroorzaakt worden door de constructie van de subdimensie beïnvloedbaarheid van het verloop van de ziekte. In deze dimensie zijn ook items opgenomen die betrekking hadden op de invloed van anderen zoals artsen, partner en vrienden. We kunnen daardoor niet spreken van de dimensie interne oriëntatie van het verloop. De cloc wijkt af van de oorspronkelijke health locus of control schaal. Dit is jammer omdat we juist geïnteresseerd waren in de relatie tussen interne oriëntatie en kwaliteit van leven.

\subsection{Praktische aanbevelingen}

Hoewel het onderzoek in eerste instantie niet is opgezet om praktische aanbevelingen te doen, geven de resultaten er toch aanleiding toe.

1. Uit het onderzoek blijkt dat continuïteit van de professionele zorgverlening beperkt aanwezig is. Ook andere onderzoekers signaleren problemen in de continuïteit van zorg (De Witte, 1991; Terpstra, 1990; Van den Bos 1989; Engelsman e.a. 1988). Ondanks het feit dat we in dit onderzoek niet hebben kunnen aantonen dat het ontbreken van continuïteit in de zorg een negatieve invloed heeft op kwaliteit van leven, willen we toch enkele aanbevelingen voor de praktijk 
doen. Continuïteit of afstemming van zorg kan namelijk voor de patiēnt én de zorgverleners van belang zijn orn de volgende redenen (Atis, 1988):

- Er kan zorg op maat, toegesneden op de individuele situatie, geleverd worden.

- Afstemming kan er voor zorgen dat de patiënten niet met te veel of te weinig zorgverleners te maken krijgt.

- Coördinatie door één persoon maakt dat de patiënt beschikt over een duidelijk aanspreekpunt voor vragen, klachten en opmerkingen. Er is dan iemand die op de hoogte is van de zorgbehoeften en de belangen van de patiënt behartigt.

- Afstemming van zorg kan verspilling van arbeidskracht, tijd en overbelasting van beschikbaar personeel voorkomen en is daardoor wellicht ook kostenbesparend.

- Als de zorg op organisatorisch gebied goed is afgestemd, is er meer tijd voor de uitvoering van inhoudelijke taken.

- Er bestaat meer inzicht in het totale zorgproces en eventuele tekortkomingen daarin.

Een van de mogelijke oplossingen voor discontinuïteit in de zorgverlening is de zorg te laten coördineren door een zorg-coördinator. Dit kan iemand zijn uit het sociale netwerk of een professionele zorgverlener die reeds betrokken is bij de zorgsituatie. De zorg-coördinator is de verbindende schakel tussen de zorgbehoeften en zorgvragen aan de ene kant en vormen van zorg en zorgverleners aan de andere kant. De coördinator heeft als taak het goed inschatten van de zorgbehoeften van de patiënt, het opstellen van en het aanbrengen van samenhang in een zorgplan, het bewaken van de uitvoering en evaluatie van het plan.

Een handig hulpmiddel, bij het coördineren van de zorgverlening door veel verschillende zorgverleners, kan het bijhouden van een logboek zijn. Daarin staat overzichtelijk vermeld wie welke taken op zich neemt en wanneer dat gebeurt. Tevens kan er door de zorgverleners in vermeld worden welke interventies hebben plaatsgevonden en bevat het logboek zogenaamde voortgangsrapportages. Zo blijven de verschillende zorgverleners op de hoogte van de zorg die door anderen wordt geboden.

Verschillende disciplines, zoals huisartsen en wijkverpleegkundigen, claimen coördinatie van zorg als hun taak. Uit dit onderzoek, maar ook uit andere onderzoeken, blijkt dat deze disciplines niet zo'n sterk coördinerende rol spelen als zou mogen worden aangenomen. Deze zorgverleners zouden niet alleen op afroep actief moeten worden maar gedurende het ziekteproces vaker op systematische wijze moeten nagaan welke zorgbehoeften er bij de patiënt bestaan. Een actievere houding bij het leggen van onderlinge contacten en het afstemmen van taken zou waarschijnlijk ook bijdragen aan een beter afgestemde zorg.

Uit de interviews blijkt dat redelijk veel patiënten moeite hebben met de bejegening van professionele zorgverleners. In de opleiding van professionele zorgverleners die omgaan met kankerpatiënten, zou meer aandacht besteed moeten worden aan communicatieve vaardigheden, het geven van informatie en het houden van 'slecht nieuws gesprekken'. 
2. Sociale steun blijkt een rol te spelen bij kwaliteit van leven en het beloop daarvan. Zorgverleners zouden systematisch moeten vragen naar het sociale netwerk van de patiënt en naar de hoeveelheid steun die de patiënt ervaart. Als zorgverleners merken dat de patiënt niet geneigd is steun te zoeken of zich eenzaam voelt kunnen ze de patiënt aanmoedigen om zijn gevoelens te tonen en steun te zoeken bij bijvoorbeeld lotgenoten of een patiëntenvereniging inschakelen. Anderzijds is het van belang alert te zijn op de wijze waarop de naasten van de patiënt reageren op de situatie. Een belangrijk aspect van de nazorg is bijvoorbeeld om patiënten en hun naasten te leren om problemen bespreekbaar te maken. Wijkverpleegkundigen, huisartsen, psychologen of maatschappelijk werkenden zouden hier een belangrijke taak in kunnen hebben.

Voorts dienen professionele zorgverleners ook te letten op de belastbaarheid van centrale verzorgers. Uit onderzoek van Jansen (1988) naar de situatie van centrale verzorgers van hulpbehoevende ouderen blijkt dat er bij centrale verzorgers regelmatig sprake is van zorgstress (fysieke klachten, psychische druk, gebondenheid aan huis, gemis aan ontspanning), relatiestress (de zorg van de een voor de ander, rolverandering, veranderingen op seksueel gebied), en netwerkstress (spanningen als gevolg van de teleurstelling dat andere netwerkleden geen steun geven en niet aan de verwachtingen voldoen). Deze constellatie van problemen kan er toe leiden dat centrale verzorgers zelf 'afknappen' en niet meer in staat zijn om adequate steun aan de patiënt te bieden. Professionele zorgverleners zoals wijkverpleegkundigen en huisartsen zouden aan de verzorgers duidelijk moeten maken dat zij een beroep kunnen doen op hulp en begeleiding.

3. Oudere patiënten, die als regel een relatief lage sociaal-economische status hebben, vormen een risicogroep als het gaat om het beloop van kwaliteit van leven. Zij lopen meer kans op een negatief beloop. Men kan veronderstellen dat deze groep patiënten minder thuis is in de gezondheidszorg, minder goed in staat is om de eigen zorg te coördineren of sociale steun te mobiliseren dan mensen die jonger zijn en een hogere status hebben. Professionals zouden extra aandacht moeten besteden aan deze groep patiënten.

\subsection{Aanbevelingen voor verder onderzoek}

De eerste aanbeveling voor verder onderzoek betreft het toetsen van de gevonden relaties in dit onderzoek bij nieuw gediagnostiseerde kankerpatiënten. Daarbij verdient het aanbeveling om slechts enkele diagnoses en/of behandelingscategorieën te kiezen. Hierbij is het van belang om meer inzicht te krijgen in de nu nog onduidelijke relatie tussen ernst van de ziekte, sociaal-economische status, sociale steun, tevredenheid over de zorg en kwaliteit van leven. Ook zouden andere factoren die kwaliteit van leven en de veranderingen daarbinnen kunnen verklaren in een nieuwe model moeten worden toegevoegd, zoals bijvoorbeeld copingstrategieën, co-morbiditeit en ziektelast in het gezin.

De onderzoeksperiode zou langer moeten zijn om de veranderingen in kwaliteit van leven en bijvoorbeeld sociale steun op lange termijn te kunnen vaststellen. In ons onderzoek hebben we nauwelijks inzicht gekregen in de situatie voordat de 
diagnose werd gesteld. Het verdient aanbeveling om zo kort mogelijk na de diagnose te starten met onderzoek. Een andere mogelijkheid om de veranderingen te bestuderen is om een prospectief cohortonderzoek te doen bij zeer veel, in beginsel gezonde respondenten die gedurende langere periode gevolgd moeten worden.

Uit dit onderzoek blijkt evenals uit vele andere onderzoeken dat continuïteit van de zorgverlening een probleem vormt. Nieuwe studies met betrekking tot dit onderwerp zouden meer in een experimentele richting moeten gaan waarbij bijvoorbeeld de invloed van zorg-management op de organisatiegerichte en patiëntgerichte afstemming wordt getoetst. Tevens zou meer aandacht moeten worden besteed aan de daadwerkelijke inhoud van de zorg en de afstemming daarvan.

Bij onderzoek naar de relatie tussen sociale steun en kwaliteit van leven zou meer aandacht besteed moeten worden aan de richting van de gevonden verbanden en het onderscheid tussen emotionele en praktische steun. Tevens zouden er meer specifieke maten met betrekking tot de aard van de steun en deelnetwerken gebruikt moeten worden.

\subsection{Slotbeschouwing}

Wat in dit onderzoek gevonden is, kan niet geformuleerd worden in definitieve conclusies. De waarde van dit onderzoek moet gezien worden in het licht van een exploratie van een 'ingewikkelde' veldsituatie.

Door dit onderzoek is meer inzicht verkregen in de kwaliteit van leven van patiënten met kanker en de veranderingen daarin, gedurende één jaar van het ziekteproces. Het is duidelijk geworden dat de kwaliteit van leven gemiddeld verbetert maar dat er bij een aantal patiënten beperkingen in het functioneren en klachten blijven bestaan. Ondanks de beperkingen in het functioneren en de klachten zijn patiënten in het algemeen tevreden over het leven en voelen zij zich goed.

Ook is door dit onderzoek inzichtelijker geworden hoe de organisatie van de professionele zorg verloopt bij deze patiëntencategorie en welke knelpunten daarin te onderscheiden zijn.

Het bestuderen van structurele en doelstellingsaspecten van sociale steun leverde interessante informatie op, over met name de veranderingen in de in netwerkgrootte en over de hoeveelheid ervaren steun.

Getracht is de samenhang tussen kenmerken van zorg, ziektekenmerken, sociale positie, beheersingsoriëntatie en kwaliteit van leven in kaart te brengen.

Sommige van de verwachte verbanden zijn inderdaad gevonden; de ernst van de ziekte blijkt negatief samen te hangen met kwaliteit van leven en een hogere sociaal-economische status beïnvloedt het beloop van kwaliteit van leven positief. Daarnaast blijkt ook leeftijd van invloed te zijn op het beloop van kwaliteit van leven.

De verwachte verbanden tussen continuïteit van de professionele zorgverlening en kwaliteit van leven worden slechts ten dele gevonden en zijn soms tegengesteld 
aan onze verwachting. Kwaliteit van leven hangt samen met takovereenstemming, met het aantal zorgverleners en met de tevredenheid over de zorg. Interessant is dat kwaliteit van leven niet alleen samenhangt met ernst van de ziekte. Het aantal betrokken professionele zorgverleners en de taakovereenstemming tussen specialist en huisarts blijken nauwelijks samenhang te vertonen met de ernst van de ziekte maar wél met kwaliteit van leven. Het inschakelen van de professionele zorg en de taakovereenstemming wordt waarschijnlijk meer beïnvloed door hoe patiënten zich voelen en hoe zij functioneren in het dagelijks leven dan door de objectieve ernst van de ziekte.

Er blijkt, zoals verwacht, een (zwakke) samenhang te bestaan tussen ervaren emotionele steun en kwaliteit van leven. Geen enkel verband is echter gevonden tussen de structurele aspecten van het sociale netwerk en kwaliteit van leven. Ook de beheersingsoriëntatie blijkt geen enkele rol te spelen.

Dat sommige van de verwachte verbanden niet gevonden zijn wordt waarschijnlijk voor een deel veroorzaakt door de methodologische problemen in dit onderzoek zoals een kleine positieve selectie van patiënten en het fenomeen regressie naar het gemiddelde. Het toetsen van de verbanden bij patiënten die niet aan alle drie de metingen meededen (de uitvallers) en de vergelijkingsgroep van patiënten in Maastricht leidt tot de conclusie dat de resultaten weliswaar niet generaliseerbaar zijn naar alle kankerpatiënten maar dat sommige van de verbanden ook bij een minder positieve selectie van patiënten van toepassing zijn.

De onderzoeksresultaten hebben geleid tot een herzien onderzoeksmodel dat in de toekomst op zijn waarde getoetst zal moeten worden. 


\section{.}




\section{Samenvatting}

Kanker is een ernstig en omvangrijk gezondheidsprobleem dat sociale processen, dagelijkse bezigheden en het psychische evenwicht zodanig kan ontregelen dat er sprake is van aantasting van de kwaliteit van leven. Het eerste doel van dit onderzoek is inzicht te krijgen in hoe (nieuw gediagnostiseerde) kankerpatiënten de kwaliteit van hun leven beoordelen en hoe deze beoordeling verandert in een jaar tijd. De tweede doelstelling is gericht op de vraag in hoeverre ervaren kwaliteit van leven en het beloop daarvan beïnvloed wordt door continuitteit van de professionele zorgverlening, door de mate van sociale steun en door enkele persoonsgebonden kenmerken van de patiënt. De veranderingen die plaatsvonden in de zorgfactoren (continuïteit van de professionele zorgverlening en sociale steun) zijn eveneens beschreven.

Het theoretisch raamwerk van het onderzoek is beschreven in hoofdstuk 2 .

Het is evident dat de ziekte kanker en de behandeling daarvan van invloed zijn op kwaliteit van leven. Kwaliteit van leven wordt in dit onderzoek beschouwd als een multidimensioneel subjectief oordeel van mensen over hun leven. We onderscheiden daarbij de dimensies: (dis)functioneren en (on)welbevinden.

Uit de literatuur blijkt dat de overlevingsprognose, het stadium van de ziekte en het tijdsverloop sinds de diagnose en behandeling factoren zijn die kwaliteit van leven beïnvloeden. Verwacht werd dat in de eerste fase van het ziek-zijn, bij een slechte prognose en bij metastasering de kwaliteit van leven sterker is aangetast dan bij een goede prognose en afwezigheid van metastasen. Bovendien werd aangenomen dat als de patiënt na verloop van tijd 'ziektevrij' is, de kwaliteit van leven zal toenemen.

In dit onderzoek zijn behalve een aantal kenmerken van de ziekte en de behandeling ook kenmerken van professionele zorgverlening bestudeerd die een indicatie vormen voor continuïteit van de zorgverlening. Het gaat daarbij om de afstemming van de zorg tussen betrokken zorgverleners onderling en om de afstemming van de zorg op behoeften van de patiënt. Verondersteld werd dat patiënten die langdurig, intensieve zorg ontvangen, te maken krijgen met fragmentatie, 
culturele discontinuïteit en projectmatigheid van de zorg. In dit onderzoek zijn we nagegaan in hoeverre deze kenmerken van de zorgverlening van invloed zijn op de kwaliteit van leven van patiënten. Verwacht werd dat bij een beter afgestemde zorg (organisatie- en patiëntgericht) minder hiaten en doublures in de zorg ontstaan, waardoor de kwaliteit van leven gunstig wordt beïnvloed.

Naast de kenmerken van professionele zorgverlening is ook sociale steun onderzocht. Uitgaande van de zogenaamde 'ruiltheorie' werd verondersteld dat als gevolg van de ernstige verstoring van de gezondheidstoestand veranderingen optreden in het sociale netwerk, in de hoeveelheid ervaren steun en in de wederkerigheid van die steun. Verwacht werd bovendien dat sociale steun vanuit een groot, open netwerk met een diverse samenstelling een positieve invloed heeft op kwaliteit van leven of een verzachtend effect heeft op de gevolgen van de ziekte en de behandeling.

Op basis van literatuurstudie hebben we ook enkele indicatoren voor sociale positie (geslacht, leeftijd, sociaal-economische status en burgerlijke staat) in het onderzoek opgenomen. Verwacht werd dat een relatief sterke sociale positie een gunstig effect heeft op de kwaliteit van leven.

Tenslotte werd ook de relatie tussen kwaliteit van leven en de beheersingsoriëntatie onderzocht omdat uit literatuur gebleken is dat deze oriëntatie van invloed kan zijn op het functioneren en welbevinden van mensen. Verwacht werd dat er een positieve relatie bestaat tussen een interne oriëntatie en kwaliteit van leven.

In hoofdstuk 3 zijn de onderzoeksopzet en de operationalisatie van de variabelen beschreven. Het onderzoek is uitgevoerd in de regio Noord-Limburg en in Maastricht en omgeving. De selectie van patiënten in Noord-Limburg heeft plaatsgevonden door de patholoog-anatoom van het ziekenhuis in Venlo, in samenwerking met huisartsen in de regio. In Maastricht heeft de selectie plaatsgevonden door specialisten van het Academisch Ziekenhuis. Van iedere patiënt is, indien mogelijk, de huisarts, de behandelend specialist, de wijk- of ziekenhuisverpleegkundige en de centrale verzorger geĩnterviewd. Deze onderzoekseenheden zijn én jaar lang gevolgd. In dat jaar vonden drie metingen plaats aan de hand van interviews en schriftelijke vragenlijsten.

Kwaliteit van leven is geoperationaliseerd door middel van de SIP, de klachtenlijst voor kankerpatiënten en twee globale evaluatie maten.

Continuiteit van de professionele zorgverlening is geoperationaliseerd met behulp van enkel indicatoren: onderlinge contacten tussen zorgverleners, taakovereenstemming tussen huisarts en specialist, contacten met steeds dezelfde zorgverleners gedurende de onderzoeksperiode, nazorg, tevredenheid met de zorg en overeenstemming tussen zorgverleners en patiënt met betrekking tot zorgbehoeften. Bij sociale steun hebben we twee soorten kenmerken onderscheiden: structurele kenmerken (grootte, dichtheid en samenstelling van het netwerk) en functionele kenmerken (ervaren en geboden emotionele en praktische steun, wederkerigheid van de steun). De beheersingsoriëntatie ten slotte is geoperationaliseerd door middel van de Cancer Locus of Control schaal. 
In hoofdstuk 4 is de selectie van de onderzoekseenheden beschreven. In NoordLimburg deden 79 patiënten mee aan de eerste meting. Tijdens de onderzoeksperiode was er sprake van uitval van patiënten door overlijden en weigering van verdere medewerking, in totaal $38 \%$. Uiteindelijk bleef een volledige responsgroep over van 51 patiënten. Het betreft een positieve selectie van patiënten: het gaat om personen met een relatief goede overlevingsprognose. Verder telt de groep minder patiënten met metastasen dan de groep uitvallers. De gemiddelde leeftijd bedroeg 61 jaar. De meeste patiënten woonden al dan niet gehuwd samen met een partner, waren vrij laag opgeleid en waren gemiddeld 3.5 maanden ziek. Vrouwen waren in de groep oververtegenwoordigd $(61 \%)$.

In Maastricht zijn bij de eerste meting 38 patiënten geïnterviewd. De uitval bedroeg hier $58 \%$. Een volledige responsgroep van zestien patiënten bleef over. Ook hier gaat het om een positieve selectie van patiënten. De Noord-Limburgse en Maastrichtse volledige responsgroepen verschillen van elkaar. De patiënten in Maastricht zijn gemiddeld jonger, veel langer ziek, hebben een hogere sociaaleconomische status, hebben vaker metastasen, kennen andere diagnoses en hebben vaak een uitgebreidere behandeling ondergaan, dan de patiënten in NoordLimburg. Dit betekende dat de twee groepen niet kunnen worden samengenomen in verdere analyses.

In Noord-Limburg is de respons van de centrale verzorgers goed: $43(84 \%)$ van hen zijn geïnterviewd. Ook de respons van de huisartsen is hoog te noemen: van 48 patiënten ( $94 \%$ ) zijn gegevens van de huisarts beschikbaar. De respons van de behandelend specialisten is bij de eerste meting nog acceptabel (67\%) maar neemt drastisch af bij de tweede meting. Op het derde meetmoment zijn geen vragen meer aan de specialisten gesteld. Omdat er zeer weinig wijkverpleegkundigen $(n=14)$ bij de zorg van deze patiënten betrokken zijn, zijn de gegevens over deze zorgverleners verder niet in dit proefschrift opgenomen.

In Maastricht varieert de respons van de centrale verzorgers van $63 \%$ tot $69 \%$. De respons van de specialisten is hoog ( $94 \%$ op tl en $88 \%$ op t3). De respons van de huisartsen is wisselend, variërend van $75 \%$ bij de eerste meting tot $44 \%$ bij de derde meting. Ook hier zijn de gegevens van de zes deelnemende verpleegkundigen niet verder geanalyseerd.

In hoofdstuk 5 is een beschrijving gegeven van de kwaliteit van leven van patiënten en de veranderingen daarin op groeps- en individueel niveau. Wat het functioneren betreft rapporteren patiënten gedurende de onderzoeksperiode de meeste problemen bij huishoudelijke activiteiten, recreatie en vrije tijd, slapen en mobiliteit. De meest genoemde lichamelijke en psychische klachten zijn moeheid, pijnlijke spieren, zenuwachtigheid, slapeloosheid en gespannen zijn. Patiënten blijken op de globale maten van kwaliteit van leven gemiddeld hoog te scoren. In het algemeen is men tevreden over het leven en voelt men zich goed. Gemiddeld rapporteren de patiënten uit Maastricht een slechtere kwaliteit van leven dan de patiënten in Noord-Limburg. Ten aanzien van het functioneren en ten aanzien van de klachten treedt, gedurende de onderzoeksperiode van een jaar, gemiddeld een 
verbetering op. De globale evaluatie over het leven verandert echter niet of nauwelijks. Omdat de indicatoren voor kwaliteit van leven onderlinge samenhang vertonen en om datareductie te bewerkstelligen zijn principale componentenanalyses uitgevoerd op de vier indicatoren van kwaliteit van leven. Alle indicatoren blijken hoog op één factor te laden; er blijft één afhankelijke variabele over. Vanwege het lineaire verloop van de veranderingen en met het oog op datareductie zijn alleen de eerste en derde meting geanalyseerd. Om de individuele veranderingen te bestuderen zijn patiënten, aan de hand van de veranderingen op de vier afzonderlijke maten voor kwaliteit van leven, ingedeeld in twee groepen: patiënten die vooruit zijn gegaan en patiënten die achteruit zijn gegaan of gelijk zijn blijven scoren.

Omdat de volledige responsgroepen van Noord-Limburg en Maastricht niet alleen op de onafhankelijke maar ook op de afhankelijke variabelen van elkaar verschillen werd besloten om alleen de analyses met betrekking tot de groep uit NoordLimburg te presenteren. De Maastrichtse patiëntengroep heeft verder als vergelijkingsgroep gediend.

In hoofdstuk 6 is een aantal kenmerken van de ziekte en van de behandeling beschreven. Ook de sociale positie en de beheersingsoriëntatie zijn aan de orde gekomen en gerelateerd aan kwaliteit van leven en het beloop daarvan.

Uit de bivariate transverale analyses blijkt dat naarmate patiënten ernstiger ziek zijn volgens objectieve maatstaven (een slechtere overlevingsprognose en metastasen hebben), ze een lagere kwaliteit van leven op het eerste en derde meetmoment rapporteren. Tussen de tijd die verlopen is sinds het vaststellen van de diagnose (ziekteduur) en kwaliteit van leven zijn geen verbanden gevonden. Over de diagnose en de behandeling in relatie tot kwaliteit van leven kan weinig gezegd te worden. Het gaat immers om een zeer heterogene en kleine groep van patienten waardoor eventuele verschillen niet gevonden zijn. Tussen de ziektekenmerken en het beloop van kwaliteit van leven zijn geen verbanden gevonden. Leeftijd en sociaal-economische status blijken geen relatie te vertonen met de kwaliteit van leven op het eerste en derde meetmoment maar wél met het beloop van kwaliteit van leven. Patiënten met een negatief/gelijk beloop zijn gemiddeld ouder en hebben een lagere sociaal-economische status. Tussen de beheersingsoriëntatie en kwaliteit van leven of het beloop daarvan is geen enkel verband gevonden.

Hoofdstuk 7 geeft een beschrijving van de mate van continuïteit van de professionele zorgverlening en van de verbanden tussen continuïteit van de zorgverlening en kwaliteit van leven. Kankerpatiënten krijgen in het algemeen met veel verschillende zorgverleners te maken. In het begin van het ziekteproces is het aantal verschillende zorgverleners groter dan in de latere fasen van het ziekteproces. Tussen deze zorgverleners bestaan er weinig onderlinge contacten en ook weinig overeenstemming over de verantwoordelijkheid bij taken. Een kleine meerderheid van de patiënten ontvangt zorg van én specialist tijdens de onderzoeksperiode; 
veertig procent van de patiënten heeft met meer dan één behandelaar te maken. Bij veel (nieuw gediagnostiseerde) patiënten komt de huisarts en/of wijkverpleegkundige op huisbezoek, nadat de patiënt is ontslagen uit het ziekenhuis. Na verloop van tijd nemen contacten met de huisarts en de wijkverpleegkundigen af. Ondanks het feit dat patiënten en centrale verzorgers klachten uiten over het gebrek aan steun en informatie, over onbehoorlijke bejegening en over de diagnosegesprekken, zijn ze in het algemeen tevreden over de zorgverlening. De tevredenheid over de zorgverlening neemt echter na verloop van tijd af.

Wat de overeenstemming over zorgbehoeften betreft blijken er, vooral bij de behoefte aan hulp bij huishoudelijke activiteiten en ziekteverwerking, discrepanties te bestaan tussen de mening van de patiënt en die van de zorgverleners.

Tussen de 'objectieve' ernst van de ziekte en continuïteit van de zorgverlening blijken er slechts enkele verbanden te bestaan: patiënten die ernstiger ziek zijn hebben met meer specialisten te maken en zijn ontevredener over de zorgverlening, dan patiënten die minder ernstig ziek-zijn.

Bij de transversale bivariate analyses zijn negatieve verbanden gevonden tussen taakovereenstemming en kwaliteit van leven alsmede tussen het aantal zorgverleners en kwaliteit van leven. Respondenten met een relatief lagere kwaliteit van leven krijgen van meer verschillende zorgverleners zorg en er is bij deze patienten meer taakovereenstemming tussen huisarts en specialist, dan bij patiënten met een relatief hoge kwaliteit van leven. Patiënten met een relatief hoge kwaliteit van leven blijken op het eerste meetmoment tevredener te zijn over de zorgverlening dan andere patiënten. Een negatief/gelijk beloop van kwaliteit van leven hangt samen met relatief veel contacten met professionele zorgverleners, een relatief hoge taakovereenstemming en een relatief grote tevredenheid met de zorgverlening. Een buffereffect van continuitteit van de zorgverlening is niet aangetoond.

In hoofdstuk 8 is aandacht besteed aan sociale steun. De patiënten hebben gemiddeld een klein, dicht netwerk, dat voor het grootste deel uit familieleden bestaat. De gemiddelde netwerkgrootte neemt iets af na verloop van tijd. Bij de eerste meting ervaren patiënten gemiddeld redelijk veel emotionele steun. Na verloop van tijd vindt er een significante afname van de hoeveelheid emotionele steun plaats. De gemiddelde hoeveelheid ervaren praktische steun verandert niet in de tijd. De balans bij emotionele steun en praktische steun is gemiddeld ongeveer in evenwicht. Er blijkt geen significante samenhang te bestaan tussen ernst, respectievelijk ziekteduur en de indicatoren voor sociale steun. Uit de bivariate analyses blijkt dat weinig emotionele steun samengaat met een slechtere kwaliteit van leven en een negatief beloop van kwaliteit van leven. Tevens blijkt dat bij patiënten met een negatief beloop van kwaliteit van leven de afname van de hoeveelheid emotionele steun, in de loop der tijd, groter is dan bij patiënten met een positief beloop. 
In hoofdstuk 9 zijn de resultaten van de multivariate analyses gepresenteerd. We hebben daarbij een onderscheid gemaakt tussen de transversale analyses en de longitudinale analyses. De transversale analyses leiden uiteindelijk tot een model van determinanten en resultanten van kwaliteit van leven:

- hoe ernstiger de ziekte, hoe lager de kwaliteit van leven.

- een relatief lage kwaliteit van leven leidt tot meer professionele zorg.

- naarmate patiënten een slechtere kwaliteit van leven hebben, bestaat er meer taakovereenstemming tussen huisarts en specialist.

- er is een tendens dat weinig emotionele steun samenhangt met een slechtere kwaliteit van leven

- er is een tendens dat een slechtere kwaliteit van leven samengaat met meer praktische steun.

Uit het onderzoek naar de determinanten van het beloop van kwaliteit van leven blijkt dat patiënten met een positief beloop gemiddeld jonger zijn, met minder professionele zorgverleners te maken hebben op het eerste meetmoment en meer praktische steun ervaren op eerste meetmoment, dan patiënten met een negatief beloop of gelijke score. Bovendien is er bij de patiënten met een positief beloop minder sprake van taakovereenstemming; zij blijken minder tevreden te zijn over de zorgverlening en meer emotionele steun te ervaren op het derde meetmoment.

In dit hoofdstuk is een vergelijking gemaakt tussen de Noord-Limburgse en de Maastrichtse groep wat betreft de kenmerken van zorg en is nagegaan of het gevonden model ook van toepassing is op de Maastrichtse situatie. Ook bij de Maastrichtse groep blijkt dat de ernst van de ziekte negatief samenhangt met kwaliteit van leven en dat ouderen en mensen met een lagere ses een negatiever beloop van kwaliteit van leven hebben dan jongeren en personen met een hogere ses. Eveneens in overeenstemming met het gevonden model is dat ook bij de Maastrichtse patiënten met een negatief beloop sprake is van meer taakovereenstemming tussen huisarts en specialist, dan bij patiënten met een positief beloop. De andere geselecteerde variabelen vertonen geen significante samenhang met kwaliteit van leven, bij deze groep.

In hoofdstuk 10 zijn de resultaten van het onderzoek geëvalueerd aan de hand van de in hoofdstuk 2 geformuleerde vraagstellingen en verwachtingen. Daarnaast komen er enkele methodologische problemen aan de orde zoals het geringe aantal respondenten, de selectieve uitval, regressie naar het gemiddelde en tekortkomingen van de meetinstrumenten. Vanwege de methodologische kanttekeningen moeten de onderzoeksresultaten met enige voorzichtigheid worden gehanteerd. Het is daarom noodzakelijk om gevonden verbanden in verder onderzoek opnieuw te toetsen. Hoofdstuk 10 bevat verder nog enkele aanbevelingen voor de praktijk. Zo worden voorstellen gedaan om de continuïteit van de professionele zorgverlening te verbeteren. Het zou verder wenselijk zijn als professionele zorgverleners meer aandacht besteden aan de ervaren sociale steun en de centrale verzorgers 
van patiënten, alsmede aan risicogroepen; te weten ouderen en patiënten met een lage sociaal-economische status. Het hoofdstuk eindigt met enkele aanbevelingen voor verder onderzoek en een slotbeschouwing. 



\section{Summary}

Cancer is a serious and extensive health problem. It can disorganize social processes, daily functioning and mental stability in such a way that one may speak of an adverse effect on quality of life.

The first purpose of this study was to get insight into the way recently diagnosed cancer patients judge their quality of life and in what way this judgement changes over a year.

Secondly the study was aimed at the question to what extent the experienced quality of life and its course are being influenced by the continuity of professional care, the amount of social support and some personal characteristics. The changes that took place in the aspects of care (continuity of professional care and social support) have also been described.

The theoretical framework of the study is described in chapter 2.

It is evident that cancer and its treatment influence quality of life. In this study quality of life was considered as a multidimensional, subjective opinion of people on their lives. Functioning and well-being were distinguished as dimensions of quality of life.

It appears from the literature that the prognosis for survival, the stage of the disease and the period of time since the diagnosis and treatment, were established as factors that influence quality of life.

It was expected that in the first stage of the disease, in case of metastases and a bad prognosis, quality of life would be affected more than in case of a favorable prognosis and the absence of metastases. Moreover it was assumed that when after a period of time the patient was disease-free, the quality of life would improve.

Besides aspects of the disease and treatment, indicators of continuity of professional care, were taken into consideration. The issue here was the co-ordination of care between care providers involved and the tuning of care on the needs of the patient. 
We assumed that patients receiving long-term, intensive care would meet with fragmentation and cultural dyscontinuity of care and a health care system that is oriented more on 'projects' than on the personal experiences of patients.

In this study we worked out to what extent these characteristics of professional care influence the quality of life of patients. It was expected that with a more harmonised care (aimed at organization and patient), less gaps and duplications would arise. This could have a favourable influence on quality of life.

In addition to the characteristics of professional care, social support was examined. In accordance to the 'exchange theory', it was expected that changes would occur in the size of the social network, the amount of percieved support and the reciprocity of support, due to the serious disturbance of health. It was also expected that social support from an extensive, open network of divers compostition would have a positive influence on quality of life or would have a buffereffect on the consequences of the disease and its treatment.

Several indicators for social position (sex, age, socio-economic status and marital status) were included in the study. The expectation was that a relatively strong social position would have a favourable effect on quality of life. Finally, also the relation between quality of life and the locus of control was examined because it appeared from the literature that it may influence the functioning and well-being of people and the changes in this. A positive relation between internal orientation and quality of life was expected.

In chapter 3 , the research design and the operationalisation of the variables are presented. The study was being conducted in the North of Limburg and in the 'Maastricht' area. The selection of patients in North-Limburg was done by the pathologist of the general hospital of Venlo; in Maastricht it was done by the medical specialists of the university hospital. Whenever possible, the general practitioner, the specialist, the community nurse or hospital nurse and the central caretaker of every patient were interviewed. These cases have been followed for one year. In this year three measurements took place by means of interviews and questionnaires.

Quality of life was operationalised by means of the Sickness Impact Profile, the Rotterdam Symptoms list and two global evaluation measures.

Continuity of professional care was operationalised by means of several indicators: mutual contacts between professional careproviders, 'job' accordance between g.p and specialist, contacts with the same careproviders during the research period, aftercare, satisfaction with care and accordance between careproviders and patients concerning patient needs.

In case of social support we distinguish between two kinds of characteristics: structural characteristics (size, density and composition of the network) and functional characteristcs (experienced and offered emotional and practical support, reciprocity of support).

Finally, the locus of control was operationalised by means of the Cancer Locus of Control scale. 
In chapter 4, the selection of the cases is described. In North-Limburg, 79 patients participated in the first measurement. During the research-period we had to deal with drop out caused by death, serious illness and refusal for further cooperation, $38 \%$ in total. Eventually a complete response group of 51 patients remained. It is a positive selection of patients: persons with a relatively good prognosis. This group also contained less patients with metastases than the group of drop-outs. The average age was 61 . Most patients lived together with a partner, married or not married, were relatively low educated and they were ill for 3.5 months, on average. Women were overrepresented (61\%).

In Maastricht 38 patients were present at the first measurement. The drop-out percentage was $58 \%$. A complete response-group of 16 patients remained. It appeared to be a positive selection of patients. The response groups of NorthLimburg and Maastricht were completely different. The patients in Maastricht were on average younger, ill for a longer period, had a higher socio-economic status, more metastases, other diagnosis and were treated more extensively. This implied that the two groups could not be combined in further analyses. In North Limburg the response of the central careproviders was high: 43 (84\%) were interviewed. Also the response of the general practitioners was high: data of 48 patients $(95 \%)$ were available. The response of the specialists was acceptable $(67 \%)$ at the first measurement, but it reduced drastically at the second one. At the third measurement the specialists were excluded from the study. Because very few community nurses were involved $(n=14)$, the data concerning these careproviders have not been included in this theses. In Maastricht the response of the central careproviders varied between $63 \%$ and $69 \%$. The response of the specialists was high ( $94 \%$ on $\mathrm{t} 1$ and $88 \%$ on $\mathrm{t} 3$ ) and that of the g.p's varied from $75 \%$ at the first measuring to $44 \%$ at the third. Because only six hospital nurses participated, the data concerning nurses were not analysed either.

In chapter 5 a description is given of the quality of life of patients and the changes at group or individual level. In relation to functioning, patients reported during the research period problems with household acitivities, recreation and pastime, sleeping and mobility. The physical and mental symptoms that occured most often were tiredness, painful muscles, nervousness, sleeplessness and feeling tense. It appeared that patients scored positive on the global measures of quality of life. In general people were satisfied with their lives and they were feeling well. Patients from Maastricht on average reported a worse quality of life than those in North-Limburg. With regard to the functioning and the symptoms we found an average improvement during the follow-up period of one year. The global evaluation on life however, hardly changed at all. Because the indicators for quality of life showed a correlation and in order to realize datareduction, a principal component analyses was conducted on the four indicators of quality of life. All indicators appeared to load on one factor; one dependent variable remained. Due to the linear course of the changes and because of the need for datareduction, only the first and the third measurement were analysed. In order to study the individual changes, the patients were divided into two groups on the basis of changes in the four indicators of quality of life: the patients improving and the 
patients having a relapse or remaining equal. We decided to use only the complete North-Limburg response group in the correlational parts. The patient group from Maastricht was used as a comparative group.

In chapter 6 we described a number of characteristics of the disease and the treatment, the social position and locus of control and we related these factors to quality of life and its course.

It appeared from the bivariate transversal analyses that when patients were more seriously ill according to objective standards (having metastases and a bad prognosis), they reported a lower quality of life at the first and the third measurement. No relation was found between the time elapsed since the diagnosis was set and quality of life. Little could be said about the diagnosis and the treatment in relation to quality of life. After all, we are dealing with a very small and heterogeneous group of patients which made it impossible to guide any differences on diagnosis and treatment.

No relations were found between disease related characteristics and the course of quality of life.

Age and socio-economic status showed no relation to quality of life on the first and third measurement, but these variables were related to the course of quality of life. Patients with a negative course and patients with an equal quality of life were on the average older and had a lower socio-economic status. No correlation was found between the locus of control and the quality of life, or the course of it.

Chapter 7 deals with a description of continuity of professional care and the relation between continuity of care and quality of life. In general, cancer patients had to deal with a lot of different care providers. At the beginning of the disease course, the number of different care providers was larger than in the later stages of the disease course. Between these careproviders there was little contact and hardly any agreement on responsibility of tasks. A small majority of the patients was taken care of by one specialist during the follow-up period; $40 \%$ of the patients had to deal with more than one doctor. With many (recently diagnosed) patients, the g.p and/or the community nurse made home visits, after the patients had been discharged from hospital. Between the first and the third measurement the contacts with the general practitioner and nurses decreased. Despite of the fact that patients and central careproviders complained about the lack of support and information, about improper treatment and about diagnosis discussions, in general they were satisfied with the care. This satisfaction, however, decreased between the first and third measurement. With regard to the accordance on care needs, it appeared that, especially with care in household activities and coping with the disease, discrepancies occured between the patients' opinion and that of care providers.

Only a few relations existed between the objective seriousness of the disease and the continuity of care: patients who were seriously ill had to deal with more specialists and were more dissatified with the care.

In the transversal bivariate analyses, negative relations were found between agreement on tasks and quality of life, as well as between the number of care 
providers and the quality of life. Respondents with a relatively lower quality had more careproviders and in these cases there was more job accordance between specialists and general practitioners. Patients with a relatively low quality of life appeared to be more satisfied with the care provided at the first measurement. Considering the changes in quality of life we found that a negative course was related to more contacts with professionals, more agreement on tasks and more satisfaction about care providing. A buffer-effect of continuity of care could not be found.

In chapter 8 attention was paid to social support. The patients were supported by small, dense networks consisting mostly of family members. The size of the networks decreased after some time. At the first measurement, patients experienced relatively much emotional support. Between the first and third measurement there was a significant decrease in the amount of emotional support. The average amount of experienced instrumental support did not change much over time. The reciprocity with regard to support was not affected. On average, emotional as well as instrumental support were balanced. There appeared to be no significant correlation between seriousness of illness, time since diagnosis and the indicators for social support, respectively. In the bivariate analyses it appeared that less emotional support was related to a lower quality of life as well as to a negative course of quality of life. It also appeared that patients with a negative course of quality of life, experienced a larger decrease in the amount of emotional support than patients with a positive course.

In chapter 9 the results of the multivariate analyses were presented. We distinguished between transversal and longitudinal analyses. The transversal analyses eventually lead to a model of determinants and resultants of quality of life:

- the more seriously ill, the lower the quality of life.

- a relatively low quality of care leads to more professional care.

- the more patients experience a lower quality of life, the more 'task-agreement' there is between specialist and general practitioner.

- there is a tendency that little emotional support is related to a lower quality of life.

- there is a tendecy that a lower quality of life is related to more practical support.

In the exploration of the determinants of the course of quality of life, it appeared that patients with a positive course were younger on average, they had to deal with less professional careproviders ( $\mathrm{t} 1$ ) and they had experienced more practical support at $\mathrm{tl}$ than patients with a negative or unchanging course of quality of life. Besides these results there was less 'task-agreement' with patients having a positive course; they appeared to be less satisfied with received care and to experience more emotional support at $\mathrm{t} 3$.

In this chapter we also compared the 'Maastricht' group with the 'North-Limburg' group. Relations between 'seriousness' of disease, age, ses, task-agreement 
and quality of life seem to develop in the same direction as in the North-Limburg group.

In chapter 10 the results of the study have been evaluated with regard to questions and expectations formulated in chapter 2 . The findings have already been discussed in this summary. In addition to this, several methodological problems have been dealt with, for example the small number of respondents, concerning the selective drop-out, regression to the mean and the shortcomings in the instruments.

Chapter 10 furthermore contains some recommendations for practical applications. These are suggestions with regard the improvement of continuity of care, some attention of professional care providers for the social network of patients and also attention for high-risk groups: elderly people and persons with a low socio-economic status. The conclusion of the chapter contains some recommendations for further research and some concluding observations. 


\section{Literatuurlijst}

Achterberg, Th. van, F.C.J. Stevens, F.L.T. Theunissen, Coördinatie van zorg in de eerste lijn. Eerste ervaringen met een experiment in de thuiszorg, Rijksuniversiteit Limburg. Maastricht, 1992.

Anderson, J.M., H. Elfert, Managing chronic illness in the family; women as caretakers. Journal of advanced Nursing, 14, 735-743, 1989.

Atis, Coördinatie van zorg, niet opeisen maar aanpakken, 1988.

Bachrach, L.L., Continuity of care for chronic mental patients; a conceptual analysis. Am. J. Psychiatry, 138, 1449-1456, 1981.

Bal, R.M., Health deviation and daily functioning in elderly rheumotoid arthritis patients. Proefschrift Rijksuniversiteit Limburg, Maastricht, 1992.

Bard, M., A.M Sutherland, Adaptation to radical mastectomy. In: The psychologocal impact of cancer. The Am cancer society, 1977.

Becker, M.H., R.H. Drachman, J.P. Kirscht, A field experiment to evaluate various outcomes of continuity of physician Care. Am. J. Public Health, 64/11, 1062-1070, 1974.

Beek, M. van, J.van Eyk, G.van Rutten, Huisartsen en specialisten over hun onderlinge taakafbakening. Medisch Contact, nr.39, 1247-1251, 1984.

Ben-Sira, Z., Lay evaluation of medical treatment and competence development of a model of the function of the physician's affective behavior, Soc.Sci.Med., 16, 1013-1019, 1982.

Ben-Sira, Z., Disability, stress and readjustment: the function of the professional's latent goals and affective behavior in rehabilitation, Soc.Sci. Med., 23/1, 43-55, 1986.

Bergner M., B.S. Gilson, The Sickness Impact Profile; the relevance of social science for medicine. Reidel publishing company, 135-150, 1980.

Bergner,M., R.A. Bobbitt, W.B Carter, B.S. Gilson, The Sickness Impact Profile; development and final revision of a health status measure. Medical Care, 19, 787-805, 1981.

Bloom, J.R., Social support system and cancer. A conceptual view. In Cohen, H.: Psychological aspects of cancer, Raven Press, 1982.

Bloom, J.R. Spiegel, The relationship of two dimensions of social support to the psychological well-being and social functioning in women with advanced breast cancer. Soc.Sci. Med., 19(8), 831-837, 1984

Blythe, J.G., T.P. Wahl, Debulking surgery, does it increase the quality of survival ? Gynaecology Oncology, 14, 396-408,1982.

Borne, H.W. van den, J.F.A. Pruyn, Lotgenotencontact bij kankerpatienten. Van Gorcum, Assen 1985.

Bos, G.A.M. van den, Zorgen van en voor chronisch zieken. Bohn, Scheltema en Holkema, Utrecht/Antwerpen, 1989.

Bruin, A.F. de, L.P de Witte, F.C.J. Stevens, J.P.M. Diederiks, De bruikbaarheid van de sickness impact profile als generieke maat voor functionele toestand. Tijdschrift voor sociale geneeskunde, 70, 160-170, 1992.

Caplan, G., Support systems and community mental health, lectures on concept development. Behavioral publications. New York, 1974.

Carter, W.B, R.A. Bobbitt, M. Bergner, B.S. Gilson, Validation of an interval scaling: the sickness impact profile. Health services research, 516-517, 1976.

Cassileth, B.R., E.J. Lusk, T.B. Strouse, Psychosocial status in chronic illness- a comparative analysis of six diagnostic groups. New England Journal of Medicine, no 8, 506-511, 1984.

Cassileth, B.R, E.J Lusk, D.S.Miller, Psychosocial correlates of survival in advanced malignant disease, New England Journal of Medicine, 312 (24), 1551-1555, 1985.

Centraal Bureau voor de statistiek, De leefsituatie van de Nederlands bevolking, 1977. Staats uitgeverij, Den Haag, 1981.

Clark, A., L.J. Fallowfield, Quality of life measurements in patients with malignant disease: a review. Jour. of the royal soc. of medicine, 79, 165-169, 1986.

Cohen S., T.A. Wills. Stress, social support and the buffering hypothesis. Psychological Bulletin. 98 (2), 310-357, 1985. 
Cohen,J., Statistical power analysis for the behavioral sciences. Ac.Press, New York/London, 1977.

Cobb, S., Social support as a moderator of life stress. Psychosomatic Medicine, 38 (5), 300-314, 1976.

Cookfair, D.L., C. Mettlin, Quality of life among cancer patients. In: P.F. Engstrom, Advances in cancer control: research and development, New York, 445-453, 1983.

Coolen, J.A., De integratie van een voorzieningensysteem. Een onderzoek naar coordinatie en integratie in de gezondheids- en welzijnszorg voor oude mensen. Proefschrift Twente, 1986.

Cox, J., B.J. Roosenschoon, Belangrijke taak voor case-manager bij oplossing doorstroomproble matiek. Het Ziekenhuis, 16 (4), 112-115, 1986.

Cuisinier, M., J. van Eyk, De konfrontatie met kanker in de huisartsenpraktijk. Knelpunten in de zorg. Metamedica, 5 \& 6. 388-397, 406-417, 1984.

Cuisinier, M.C.J, M.H. van Venrooij, J.Th.M. van Eyck, Huisarts en kankerpatient 1: de voorlichting, Medisch Contact, 36,1059-1062, 1988.

Curtis, P., J. Rogers, Continuity of Care in a Family Practice Residency Program. The Jour. of Family Practice, 8 (5), 975-980, 1979.

Dakof, G.A., S.E. Taylor, Victims' perception of social support: what is helpful from whom?, Jour. of personality and social psychology, 5 (1), 80-89, 1990.

Dam, F.S.A.M. van, A.C.G. Linssen, A.L. Couzijn, Evaluating quality of life in cancer clinical tria/s. In: Buyse, Cancer clinical trials methods and practice. Oxford University Press, Oxford 1983.

Deleeck, H., Het Mattheuseffect in de gezondheidszorg. Een voorstel tot verklaring van sociale ongelijkheden, Tijdschrift voor sociale geneeskunde, 66, 325-328, 1988.

Diederiks, J.P.M., Kwaliteit van het leven als criterium voor de kwaliteit van de gezondheidszorg bij chronisch zieken en gehandicapten. Paper presented on Marktdag Sociologen,Groningen, 1987.

Diener, E., Subjective well-being. Psychological Bulletin, 95 (3), 542-575, 1984.

Dobkin, P.L., G.R. Morrow, Long-term side effects in patients who have been treated succesfully for cancer. Journal of psychosocial oncology, 3, 23-52, 1985.

Doorn, C. van, Zeldenrust, M., Beleving en verwerking van zwaar ziek-zijn. Gesprekken met patienten en artsen. De Haan, Weesp, 1984.

Dorrepaal, K.L, Pijn bij patienten met kanker, Proefschrift, VU, Amsterdam, 1989.

Dunkel-Schetter, C. Social support and cancer:findings based on patient interviews and their implications, Journal of social issues, 40 (4), 77-98, 1984.

Dunkel-Schetter, C., C.B. Wortman, The interpersonal dynamics of cancer: problems in social relationships and their impact on the patient. In: Friedman, H.S., Interpersonal issues in health care. Academic Press, New York, 1982.

Engelsman, C., Th.P.B.M. Suurmeyer, M.Riewald, Polikinische chemotherapie en continuiteit in de zorg. Huisarts en Wetenschap, 32 (4), 130-133,1989.

Engelsman, C. M.Riewald, Continuiteit van zorg bij poliklinische chemotherapie, Med.Contact, 43, 1377-1380, 1988.

Eyk, J.Th. van, De verwerking van enkele levensgebeurtenissen en steun uit sociale netwerken. Gezondheid en samenleving, 1, 83-99, 1980.

Feather, B.L, J.M. Wainstock, Perceptions of postmastectomy patients. Part 1. The relationship between social support and network providers, Cancer Nursing, 12 (5), 293-300, 1989.

Flap, H.D., De theorie van het sociale kapitaal. Antropologische verkenningen, 6, 14-27, 1987.

Fletcher, A.E., B. Hunt, C. Bulpitt, Evaluation of OL in clinical trials of cardio vascular disease. J. Chronic Disease, 40 (6) 557-566, 1987.

Frederiks, C.M.A., P.F. Bisscheroux, Thuiszorg belemmerende factoren bij ouderen. Tijdschrift voor sociale gezondheidszorg, 63, 557-558, 1985.

Funch, D.P., C. Mettlin, The role of support in relation to recovery from breast surgery, Soc. Sci. Med., 16, 91-98, 1982. 
Geelen, K.R.J., J.F.A. Pruyn, H.W. van den Borne, C.J.M. Brunschot, Het verwerken van levensbedriegende ziekten: aangrijpingspunten voor patientenvoorlichting en ondersteun. ing, I.V.A, Katholieke Hogeschool, Tilburg, 1984.

Giel, R., W. Frankenberg. J. Oldhoff, B. Otten, E. Van der Ploeg, De chirurg-oncoloog en de kwaliteit van leven van zijn patienten. Ned.T.Geneeskunde, 121 (34), 1987.

Ginniken, I.K.S., van, W.F. van der Vlist, Kankersterfte in Nederland laatste 30 jaar verdubbeld. Tijdschrift kanker, 9, 4-10, 1985.

GGD Noord-Limburg, Kankercijfers Noord-Limburg, Venlo, 1990.

Glaser, B.G, A.L. Strauss, Besef van de naderende dood. Samson, Alphen aan de Rijn, 1973.

Gondrie, P.C.F.M., J.W.W. Coebergh, G.Hendrix, M.A. Crommelin, Wijkverpleegkundige thuiszorg voor de patient met kanker in Noord-Limburg, Tijdschrift voor sociale gezondheidszorg 65(1), 19-22,1987.

Gordon, W.A., I. Freidenbergs, Efficacy of psychosocial intervention with cancer patients. J. of consulting and clinical psychology, 48, 743-759, 1980.

Goodman, M., Managing the side effects of chemotherapy. Seminars in Oncology nursing, 5 (2), suppl 1, 29-52, 1989.

Gottschalk, L.A., Measurement of mood and affect in cancer patients. Cancer, Supplement 15, may 1984.

Granovetter, M.S., The strength of weak ties. Am.Jour. of Sociology، 78, 1360-1380, 1973.

Greenwald, H.P., S.J. Dirks, E.G. Borgatta, R. McCorckle, Work disability among cancer patients. Soc. sci. and med., 29 (11), 1253-1259, 1989.

Grol, R.A., A.S mits, H. Fransen, C.van Weel, Continuilteit in de huisartsgeneeskunde. Huisarts en Wetenschap, 30, 275-279, 1987.

Groot, A.D. de, De bevordering van welzijn. In Baerends, G.P, J.J. Groen, A.D. de Groot, Over welzijn, van Loghum, Slaterus, Deventer, 1978.

Grypdonck, M., Van continuiteit van zorg naar zorg voor continuiteit. T.V.Z, 43, nr.15, 487 492, 1989.

Haes, J.C.J.M. de, Kwaliteit van leven van kankerpatienten. Swets en Zeitlinger, Amsterdam/Lisse, 1988.

Haes, J.C.J.M. de, M.A. van Oosterom, K. Welvaart, The effect of radical and conserving surgery on the quality of life of early breast cancer patients. Eur. J. of surgical oncology, 12, 337-342, 1986.

Haes، J.C.J.M. de, J.Pruyn, F. Knippenberg, Klachtenlijst voor kankerpatienten. Eerste ervarin gen. Ned. Tijdschrift voor de Psychologie, 38, 403-422, 1983.

Haes, J.C.J.M. de., F. Knippenberg. The quality of life of cancer patients. A review of the literature. Soc.Sci. and Med., 20 (8),809-817, 1985.

Haggmark, C. T. Theorell, Coping and social activity patterns among relatives of cancer patients. Soc.Sci.and Med., 25 (9), 1021-1025, 1987.

Halfens, R., Locus of control; de beheersingsorientatie in relatie tot ziekte en gezondheidsge drag. Proefschrift Rijksuniversiteit Limburg, Maastricht, 1985.

Hall, A., B.Wellman, Social networks and social support. In: S. Cohen; Social support and health, Ac.Press, New York, $23-41,1985$.

Hansen, M.F., Continuity of care in family practice. Measurement and evaluation of continuity of care. J.of Family Practice, 2 (6),439-444, 1975.

Hanson, B.S., P.O. Ostergen, Different Social Network and Social Support Characteristics. Nervous Problems and Insomnia: Theoretical and methodological aspects on some results from the population study men born in 1914 Malmo Sweden. Soc. Sci. and Med., 25 (7), 849-859, 1987.

Harwood, A.R., E. Rawkinson, The quality of life of patients following treatment for laryngeal cancer. Int. jour. Radiation oncology biology ohysics, 9 (3), 335-338, 1983.

Heyting-v.d.Meulengraaf, J., Laat de partner van de kankerpatient niet in de kou staan. T.V.Z, 3, 77-80, 1990 .

Hill, C.E., Differential perceptions of the rehabilitation process: a comparison of client and personnel incongruit in two categories of chronic illness. Soc. Sci. and Med., vol.12, 57-63, 1978. 
Hinds C.. The needs of families who care for patients with cancer at home; are we meeting them. Jour. of advanced nursing, 10,575-581, 1985.

Hislop, T., The prognostic signifigance of psychosocial factores in women with Breast Cancer. J.Chronic Disease, 4 (7), 729-735, 1987.

Holland, J.F, E. Frei, Cancer medicine. second edition, Lea and Febiger, Phil., 1982.

Holmes, S., E.Eburs, Patients and nurses perceptions of symptom distress in cancer. Jour. of advanced Nursing, 14, 840-846, 1989.

Holmes, S., J. Dickerson, The QL : design and evaluation of a self assessment instrument for use with cancer patients. Int. J.Nursing Stud, 24 (1), 1987.

House, H.S, Work, stress and social support. Massachussets, USA, Addison Wesley, 1981.

Hughes, J.E., Emotional reactions to the diagnosis and treatment of early breast cancer. Journal of psychosomatic research, 26/2, 277-283, 1982.

Hurley, R.E., Toward a behavioral model of the physician as case-manager. Soc. Sci. and Med. $23(1), 75-82,1986$

Jansen, H.F.A., C.P.C. Breemer ter Stege, F.Doeleman, Samenhang in de zorgverlening: afstemming binnen het primaire proces van de gezondheidszorg. $M$. en 0. , 339-355, 1985.

Janssen, T., Zorg om mantelzorg, T.V.Z., nr 6, 169-174,1988.

Janssen, M., Personal networks of chronic patients. Proefschrift Rijksuniversiteit Limburg Maastricht, 1992.

Jennings, B.M., A.F. Muhlenkamp, Systematic misperception; oncology patient's self-reported affective states and their caregivers' perceptions. Cancer Nursing, 4 (12), 485-489, 1981.

Jongens A.P, Knelpunten in de kontinuiteit van zorg, een inventarisatie naar de beleving van kankerpatiënten, IKW Leiden, 1989.

Kazem, I., Inleiding in de oncologie. Dekker en v.d. Vegt, Nijmegen, 1983.

Kemper, P., The evaluation of the national long term care demonstration, Health Services Research, 23, 1988.

Knippenberg, F.C.E., Neveneffecten van radiotherapie. Studiecentrum Soc.Oncologie, K.W.F, Rotterdam, 1983.

Knipscheer, C.P.M., Oude mensen en hun sociale omgeving. Een studie van het primaire sociale netwerk. Vuga, Den Haag, 1980.

Knottnerus, J.A., A. Volovics, Overeenstemming tussen beoordelaars. Huisarts en wetenschap, $32(2), 1989$.

Kutner,N., Social ties, social support and percieved health status among chronically disabled people. Soc. Sci. and Med., 25 (1), 29-34, 1987.

Landelijk overlegorgaan kankercentra, Progress Dutch cancer registry, 1989.

Leiber, L., M.M. Plumb, The communication of affection between cancer patients and their spouses. Psychosomatic Medicine, 38, 379-389, 1976.

Levine, S., The changing terrains in medical sociology. Emergent concern with quality of life. J. Health and Social Behavior, 28, 1-6, 1987.

Lin, N., M.W. Woelfel, S.C. Light, The buffering effect of social support subsequent to an important life event. J. of Health and Social Behavior, 26, 247-263, 1985.

Linssen, A.C.G., F.S van Dam, Leven met cytostatica. Pharmaceutisch weekb/ad, 114, 501 $515,1979$.

Linssen, A.C.G., G.J. Hanewald, S. Huisman, F.S.A.M. van Dam, The development of a wellbeing questionnnaire at the Netherland Cancer Institute, Proceedings EORTC, Paris, 1982

Luttik, A., H.M. Jacobs, L.P de Witte, De sickness impact profile: een meetinstrument waarmee de invloed van ziekte en/of gezondheidsklachten op het dagelijks functioneren kan worden vastgesteld. Nederlands versie. Vakgroep huisartsgeneeskunde, Rijksuniversiteit Utrecht, 1985.

Mack, R.M., Lessons from living with cancer. New England Jour.Med., 311 (25), 1640-1644, 1984. 
Mages, N. L, G. A. Mendelsohn, Effects of cancer on patients lives: a personalogical approach. In G. C. Stone, Health Psychology, San Fransisco, Jossey- Bass, 1979.

Magill, M. K, J. Senf, A new method for measuring continuity of care in family practice residencies. Jour. of family practice, 24 (2), 1165-168, 1987.

Maguire, G. P., Psychiatric problems in the first year after mastectomy. British Medical Journal, 1, 963-965, 1978.

McDowell,I., C. Nevell, Measuring health, a guide to rating scales and questionnaires. Oxford University Press, New York, 1987.

Meagher, D. M., F. Gregor, Dyadic social support for cardiac surgery patients. A Canadian Approach. Soc. Sci. and med., 25 (7), 833 - 837, 1987.

Melker, R.A. de, De begeleiding van ziekenhuispatienten door een huisarts. Huisarts en Wetenschap, no.16, 457-464, 1973.

Meyer, O.G., T. van Kampen, Kijk op Kanker. Van Gorcum, Assen, 1984.

Melker, R.A. de, Ziekenhuispatient, huisarts, huisgezin. Een exploratief inventariserend onderzoek. Dekker en v.d.Vegt. Nijmegen, 1973.

Meyerowitz, B.E., F.C. Sparks, I.K. Spears, Adjuvant chemotherapy for breast carcinoma, psychosocial implications. Cancer, 43, 1613-1618, 1979.

Meyerowitz, B.E., I.K. Watkins, F.C. Sparks, Quality of life for breast cancer patients, receiving adjuvant chemotherapy, Am. Journal of Nursing, 2, 232-235, 1983.

Meyerowitz, B.E, Psychological correlates of breast cancer and its treatments. Psychological Bulletin, 87 (1), 108-131, 1980.

Mohlzahn, A.E., H.C. Northcott, The social bases of discrepancies in health/illness perceptions, Jour. of advanced Nursing, 24 (14), $132-140,1989$.

Mootz, M. De patient en zijn naasten; de invloed van houdingen in het persoonlijk netwerk van de patient op zijn medische consumptie. Pasmans, Den Haag, 1981.

Mor, V., Cancer patients' Quality of Life over the disease course; lessons from the real world. J. Chron. Disease, 40 (6), 535-544, 1987.

Morris, J., S. Sherwood, Quality of life of cancer patients at different stages in the disease trajectory. J.Chron. Disease, 40 (6), 545-533,1987.

Najman, J.N., Levine S., Evaluating the impact of medical care and technologies on the quality of life: a review and critique, Soc. Sci. and Med., 15, 107-115, 1981.

Nationale Kruisvereniging, Inventarisatie continuiteit van de verpleegkundige zorg, Bunnik, 1985.

Nehemkis, A., K.E. Gerber, R.A. Charter, The cancer ward: patients perceptions-staff misper ceptions. Psychotherapy and psychosomatics, 41, 42-47, 1984.

Nocross-Weintraub F., G.H.Hagopian, The effect of nursing consulation on anxiety side effects and self care of patients receiving radiation therapy. Oncology Nursing Forum, 17 (3), suppl, $31-35,1990$.

Noordhoek,M., Continuiteit van zorg, T.V.Z., 39 (17), 513-516, 1986.

Norbeck, J.S., A.M. Lindsey, V.L. Carreieri, The development of an instrument to measure social support. Nursing Research, 30, 264-269, 1981.

Northouse L.L., Social support in patients' and husbands' adjustment to breast cancer. Nursing research, 37, 91-95, 1988.

Oakley, A., L.Rajan, Social class and social support: the same or different. Sociology, 25 (1), 31-59, 1991.

Oberst, L., Patients Perceptions of Care. Measurement of Quality and Satisfaction. Cancer supp/., 15 May 1984.

Oleske, D.M., S.Heinze, D.M Otte, The diary as a means of understanding the quality of life of persons with cancer receiving home nursing care. Cancer Nursing, 13 (3), 158-166, 1990.

Orem, D.E., Nursing: concepts of practice, McGraw-Hill, New York, 1985.

Ormel, J. Een moeilijk leven ? In Veenhoven, R. Betere wereld, gelukkiger mensen?, Swets \& Zeitlinger, Lisse, 1984.

Ormel, J., H.D. Flap, Onderzoeksvoorstel NWO. Stabiliteit van persoonlijke sociale netwerken, 1989. 
Orth-Gomer, K., A.L. Unde, The measurement of social support in population surveys. Soc. Sci. and Med., 24 (1) 83-94, 1987.

Padilla, G.V., B. Ferrell, M.M. Grant, M. Rhinen, Defining the content domain of quality of life for cancer patients with pain. Cancer Nursing, 13 (2), 108-115, 1990.

Parsons. T., The social system. London: Routledge and Kegan, 1951.

Patrick, D.L, H. Peach, I. Gregg, Disablement and care: a comparison of patient view and general practitioner knowledge. Jour. of the royal college of gen.practitioners, 32, 429434, 1982 .

Philipsen, H., Het Deelproject Continuiteit van Zorg. Interne publicatie Rijksuniversiteit Limburg, Maastricht, 1986.

Philipsen, H., Rationaliteit en ons oordeel over de verdwijnende patient. Gezondheid en Samen leving, no.3. jrg.6., 142-151, 1985.

Philipsen, H., Afwezigheid wegens ziekte. Ned.Inst. voor praeventieve geneeskunde- T.N.O., Wolters-Noordhoff, Groningen, 1969.

Philipsen, H., Gezondheidszorg als project en bejegening. Waarden ten aan zien van ziekte. gezondheid en samenleving, Rijksuniversiteit Limburg, Maastricht, 1988.

Philipsen, H., Maatschappelijke criteria voor de zorg voor langdurig zieken en zorgbehoeftigen. In: Zorgvisies Prijs \& Kwaliteit, Ontwikkelingen in de gezondheidszorg, deel 15, Stichting Sympoz, 7-14, 1992.

Picauly, C., Moeten, willen, vragen, krijgen. Zorgbehoeften van ouderen onderzocht, 19821987. Ned Instituut voor gerontologie, Nijmegen, 1987.

Presant, C.A., Quality of Life in cancer patients: who measures what. Am. Joun of clin. oncologr, 7, 571-573, 1984.

Priestman, T.J., Baum, M. The quality of life in breast cancer patients. Proceedings of the first EORTC quality of life workshop, Amsterdam, 1981.

Pruyn, J.F.A, C.J.M. van Brinschot, H.M.J. Verbunt, H.W. van den Borne, De rol en betekenis van de huisarts voor kankerpatienten. Tijdschrift voor sociale gezondeheidszorg. 62 (20), 806-808, 1984.

Pruyn, J.F.A., H.W. van den Borne, R.S.M. de Reuver, De Locus of control-schaal voor kankerpatienten, Tijdschrift voor sociale gezondheidszorg, 66, 404-408, 1988.

Rijken, P.M., I.M.C.M. Plagge, De voorlichting aan oudere kankerpatiënten op de polikliniek. Doctoraalscriptie, Rijksuniversiteit Limburg, 1988.

Ris, B.G.M., J.P.M. Diederiks, Een kritische analyse van interdisciplinaire samenwerking in de hulpverlening. Tijdschrift Soc. Geneeskunde, 52, 553 - 560, 1974.

Ros, W.J.G., Sociale steun bij kankerpatienten. Proefschrift, Rijksuniversiteit Utrecht, 1990.

Ros, W.J. G., A.L. Couzijn, Social support and cancer. Paper presented at the ECCO -4Conference, Madrid Spain 1987.

Ruf-Dirksen, S.R., Perceived well-being in malignant melanoma survivors. Oncology Nursing Forum, 16 (3), 353-358, 1989.

Ruf-Dirksen, S.R., Theoretical model to predict subjective well-being. Western Journal of Nursing Research, 12 15), 629-643, 1990.

Saunders, J., R. McCorkle, Social support and coping with lung cancer. Western Journal of Nursing Research, vol. 9, 29-42, 1982.

Schag, C.C., R.L. Heinrich, The impact of cancer on daily living; A comparison with cardian patients and healthy controls. Rehabilitation Psychology, 31 (3), 1986.

Schmale, A.H., G.R.Morrow, M.H. Schmitt, L.M. Adler, Well-being of cancer survivors. Psychosomatic Medicine, 45 (2), 163-169, 1983.

Schuessler, K.F. G.A.,Fisher, Quality of life research and sociology. Am.Rev.Sociol.,11,129. $149,1985$.

Shortell, S.M. Continuity of medical care. Conceptualization and measurement. Medical Care, 14 (5), 377-391, 1976.

Shumaker, S.A., Brownell, A., Toward a theory of social support: closing conceptual gaps. Jour of soc.issues, 40,11-36, 1984.

Sie, B., Het zit in het bloed. Werkstuk universiteit van Amsterdam, 1980. 
Silberfarb, P.M., D. Philibert, P.M. Levine, Psychosocial aspects of neoplastic disease: affective and cognitive effects of chemotherapy in cancer patients. Am. Journal of Psychiatry. 137 (5), 597-601, 1980.

Slevin, M.L., H. Plant, D. Lynch, Who should measure quality of life, the doctor or the patient, Br.J.Cancer, 57(1), 109-112, 1988.

Sonderen, E. van, J. Ormel, The relationship between social network characteristics and social support. Paper presented at the Euopean conference on social network analysis, Groningen, 1989.

Spector, W.D., S. Katz, The hierachical relationship between activities of daily living and instrumental activities of daily living. J. Chronic Disease, 40 (6), 481-489, 1987.

Spinetta,J., Measurement of family function communication and cultural effects. Cancer, May 15 Suppl, 1984.

Spitzer, W.O., A.J. Dobson, I. Hall, E. Chesteman, J. Levi, Measuring the quality of life of cancer patients. A Concise QL-index for use by physicians. J. Chron.disease, vol. 34, 585-597, 1981.

Spitzer, W.O., State of Science 1986; QL and functional status as target variables for research. J.Chronic Disease, 40 (6), 465-471, 1987.

Sprangers, M.A.G., N.K. Aaronson, F.S.A.M. van Dam, Kwaliteit van leven bij therapie-evaluatie in de oncologie. Ned T. Geneesk. 134 (15), 740-743, 1990.

Staps.T. De kankerpatiënt en levenskwaliteit. Metamedica, 65, 28-41, 1986.

Starfield, B.H., D.W. Simborg, S.D. Horn, S.A. Hourtee, Continuity and coordination in primary care; their achievement and utility. Medical Care. 7, 625-636, 1976.

Stichting Toekomstscenario's Gezondheidszorg, Kanker in Nederland. Bohn, Scheltema, Holkema, Utrecht, 1987.

Strauss, A.L., Chronic illness and the quality of life. Cv mosby, St.Louis, 1975.

Sugarbaker, P.H., I. Barnofsky, S.A. Rosenburg, F.J. Gianola, Quality of life assessment of patients in extremity sarcoma clinical trials. Surgery, $91(1), 17-23,1982$.

Swaan, A. de, De mens is de mens een zorg, opstellen 1971-1981. Meulenhoff, Amsterdam, 1982.

Tabachnick, B.G., F.S. Fidell, Using multivariate statistics. Harper and Row, New York, 1983.

Taylor, S.E., R.R. Lichtman, J.V. Wood, Attributions, beliefs about control and adjustment to breast cancer. J Pers. Soc. Psychlogv, 46(3), 489-502, 1984.

Taylor, S.E., R.R. Lichtman, J.V. Wood, A.Z. Bluming, G.M. Dosik, R.L. Leibowitz.llness-related and treatment-related factors in psychosocial adjustment to breast cancer. Cancer, 55, 2506-2513, 1985.

Taylor, S.E., Adjustment to threathening events, a theory of cognitive adaptation. American Psychologist, 1161-1173, 1983.

Tempelaar, R., J.C.J.M de Haes, W.J.A. van de Heuvel, Een meetinstrument voor positieve en negatieve ervaringen van (kanker)patienten. Tijdschrift voor Sociale Geneeskunde, 65. no. $20648-653,1987$.

Tempelaar,R., J.C.J.M. de Haes, H.de Ruiter, D.Bakker, W. van den Heuvel, M.G. van Nieuwenhuijzen, The social experiences of cancer patients under treatment: a comparative study. Soc. Sci. Med., 29 (5), 635-642, 1989.

Terpstra, S.J., L.P. de Witte, F. van der Horst, D.J.P. Tilli, Leven met een neuromusculaire aandoening (1); een onderzoek bij leden van de V.S.N. Instituut voor revalidatievraagstukken, Hoensbroek, 1990.

Thoits, P.A., Conceptual, methodological and theoretical problems in studying social support as a buffer against life stress. Journal of health and social behavior, 23, 145-149, 1982.

Trimbos, K., Mensen met kanker. v. Loghum Slaterus b.v. Deventer, 1978.

Veenhoven, R., Conditions of happiness, Reidel,Dordrecht, 1984.

Visser, A.Ph., De beleving van het verblijf in het algemeen ziekenhuis: tevredenheid, kennis en emotionele toestand van ziekenhuispatienten, meting, inhoud en determinanten. Van Gorcum Assen, 1984. 
Visser, A.Ph, F.H. Menko, Samenwerking tussen echelons bij de zorg voor patienten met kanker. De visie van polimedewerkers. Med.contact, nr.39, 1239-1242, 1987.

Visser, A.Ph., Onderzoek naar tevredenheid van ziekenhuispatiënten. Doel, Methode en Be/eid. Lochem, 1988.

Vliert, E., van den, F. de Boer, Sociale steun als determinant van gezondheid: suggesties voor verder onderzoek. Gezondheid en Samenleving, 1, 2-10, 1984.

Waltz, M., Marital context and post-infarction quality of life: is it social support or something more ? Soc. sci. and med., 22 (8), 791-805, 1986.

Weinberger, M., S.L. Hiner, Assessing social support in elderly adults. Soc. Sci. and Med., 25 (9), 1049-1055, 1987.

Weisman, A.D., J.W. Worden, Psychological analysis of cancer death. Omega, 6/1, 61-75, 1975.

Weisman, A.D., A model for psychosocial phasing. General hospital psychiatry, 1, 187-195, 1979.

Wellman, B., The community question; the intimate networks of east-Yorkers. Am.Jour. of Sociologr, 84, 1201-1231, 1979.

Wilkin, D., Conceptual problems in dependency research. Soc.Sci.Med, 24 (10), 867-873, 1987.

Williams, N.S., D.Johnston, The quality of life after rectal excision for low rectal cancer. British Journal of surgery, 70, 460-462, 1983.

Wills L.A.M., Continuity of care for paatients with malignant disease. Postgraduate Med.Journ, $54,391-394,1978$.

Winnubst, J.A.M, W.J.G. Ros, A.L. Couzijn, Social support en kanker: Hoofdthema's en theoretische aanknopingspunten. Nederlands Tijdschrift voor psychologie, 42, 193-201, 1987.

Winnubst, J.A.M., Kankerpatiënten en sociale ondersteuning. Mogelijkheden en ambivalenties. Medisch contact, $\mathrm{nr} .26,885-886,1989$.

Witte, L.P. de, After the rehabilitation centre. A study into the course of functioning after discharge from rehabilitation. Proefschrift Rijksuniversiteit Limburg, Maastricht, 1991.

Witte, L.P. de, D.J.P. Tilli, A.J.G. Ticheler, B.A.C. Winants, F. van der Horst, Sj. van der Linden, Leven met een reumatische aandoening. I.R.V., Hoensbroek, 1988.

Witte, L.P. de, F. van der Horst, Continuiteit van zorg na ontslag uit een revalidatiecentrum. Tijdschrift voor sociale geneeskunde, 64 (17),566-572, 1986.

Witte, L.P. de, F.van der Horst, De waarde van de Sickness Impact Profile als maat voor het functioneren van de patient. Gezondheid en Samenleving, jrg.8.no.2, 120-127, 1987.

Witte, L.P. de, F. van der Horst, J. Joosten, Herstel van revalidatiepatienten en continuiteit van zorg. Verslag van een onderzoek en hoofdlijnen van een vervolgonderzoek. Tijdschrift voor sociale geneeskunde 63 (14) 627-629, 1985.

Wood-Dauphine, S., J.T. Williams, Reintegration to normal living as proxy the Ql. J.Chronic Disease. 40 (6), pp.491-499, 1987.

Wortman, C.B., C. Dunkel-Schetter, Interpersonal relationships and cancer. A theoretical analysis. J. of Social /ssues. 35 (1), 120-155, 1979.

Wortman, C.B., Social support and the cancer patient. Cancer, May 15 suppl.2339-2360,1984.

Wouden J.C. van der, Samenwerking van specialisten en huisartsen bij mensen die lijden aan kanker. Rotterdams Universitair Huisartsen Instituut, 1985.

Wouden J.C. van der, De opinie van huisartsen en specialisten over hun samenwerking bij bij kankerpatienten in de regio Gouda/Rotterdam. Rotterdams Universitair Huisartsen Instituut, 1986.

Zijderveld, A.C., De samenleving als schouwspel. Een sociologisch leer- en leesboek, Vuga, Den Haag, 1987. 


\section{BIJLAGE A: Categorieën van de SIP en enkele voorbeelden van items}

\section{Slapen en rusten}

- Ik breng een groot deel van de dag liggend door.

- Ik slaap of dut meer overdag.

2. Emotioneel functioneren

- Ik kan zomaar in lachen of huilen uitbarsten.

- Ik doe nerveus of ben rusteloos.

3. Lichaamsverzorging

- Ik was mezelf niet helemaal, dat doet iemand anders.

- Ik kleed mezelf wel aan maar het gaat erg langzaam.

4. Huishoudelijke activiteiten

- Ik werk wel in en bij het huis, maar korte tijd achtereen en ik rust vaak uit.

- Ik doe geen boodschappen die ik anders wel zou doen.

5. Mobiliteit

- Ik zit de meeste tijd thuis.

- Ik lig meer in bed.

6. Sociale interactie

- Ik ga minder op visite.

- Ik doe onaangenaam tegen mijn naaste familieleden/gezinsleden/huisgenoten.

7. Lopen

- Ik loop helemaal geen trappen.

- Ik loop kleine afstanden of sta vaak stil om te rusten.

8. Alertheid

- Ik maak dingen waaraan ik begin niet af.

- Ik houd mijn aandacht nergens lang bij.

9. Communicatie

- Ik heb moeite met schrijven of typen.

- Ik ben moeilijk te verstaan.

10. Recreatie

- Ik besteed meer tijd aan passief tijdsverdrijf in plaats van actief met iets bezig te zijn.

- Ik ga minder vaak uit, bijvoorbeeld naar een concert, schouwburg, film, dansen, het cafe.

11. Eten

- Ik eet veel minder dan gewoonlijk.

- Ik eet met lange tanden. 
BULLAGE B : Principale componentenanalyse Klachtenlijst

Principale Componenten analyse van de Klachtenlijst (27 items) op 11 . Factorladingen $(>.30)$, na varimax rotatie $(n=117)$.

factor $1 \quad$ factor 2

gebrek aan eetlust(1)

prikkelbaarheid $(p)$

moeheid (I)

.56

piekeren (p)

.43

pijnlijke spieren (I)

.70

neerslachtigheid (p)

.39

.76

futloosheid (I)

.33

pijn onder in rug (I)

zenuwachtigheid ( $p$ )

.60

wanhopig over toekomst(p) $\quad .75$

slapeloosheid (p)

.50

hoofdpijn (p)

duizeligheid (I)

mond of slikpijn (I)

angst ( $p$ )

.68

verminderde sex.belangs.(I)

.49

maagzuur/oprispingen (I)

.31

rillerigheid (I)

tintelingen (I)

buikpijn (I)

gespannen (p)

haaruitval (I)

brandende ogen (I)

moeilijk concentreren $(p)$

kortademigheid (I)

droge mond (I)

.46

76

$I=$ lichamelijk, $p=$ psychisch 
BIJLAGE C: Taken die werden voorgelegd aan professionele zorgverleners m.b.t. taakovereenstemming

1. Het informeren van de patiënt omtrent de diagnose.

2. De begeleiding van de patiënt tijdens opname.

3. De begeleiding van het gezin tijdens opname.

4. Het geven van medische informatie over de ziekte en behandelingsmogelijkheden.

5. Het geven van voorlichting over en het toelichten van leefregels.

6. Het voorbereiden op en informatie verstrekken over opname.

7. Begeleiding bij ziekteverwerking en acceptatieproblemen.

8. Begeleiding van gezinsleden t.a.v. eventuele problemen t.g.v. de aandoening van de patiënt.

9. Het voorbereiden van de patiënt op het ontslag en het thuiskomen na opname.

10. De coördinatie van de hulp na ontslag.

11. Voorlichting geven over het gebruik van hulpmiddelen en protheses.

12. Het bewaken van de totale zorgverlening en zonodig initiatief nemen om lacunes in de zorg op te vullen.

13. Het wegwijs maken in de voor de patiënt belangrijke instanties en regelingen. 


\section{BLJLAGE D: Principale componentenanalyse Cancer Locus of Control}

Principale componentenanalyse van de Cloc (21 items) op tl. Factorladingen $(>.30)$, na varimax rotatie $(n=87)$.

\$1 $\$ 2$

2. Ik oefen zelf een sterke invloed

uit op het verloop van mijn ziekte

17. Door gezond te leven oefen ik

invloed uit op het verloop van mijn ziekte.

20. Door te vechten tegen mijn ziekte kan

$.69^{*}$

$i k$ het verloop ervan beïnvloeden.

5. Mijn partner oefent een sterke invloed vit op het verloop van mijn ziekte.

14. Door ervoor te zorgen dat ik lichamelijk

blijf kan ik het verloop van mijn ziekte

beïnvloeden.

19. Als ik de voorschriften van mijn dokter opvolg beïnvloed ik het verloop van de ziekte.

4. Mijn arts oefent een sterke invloed uit op het verloop van mijn ziekte.

7. Vrienden en kennissen oefenen een sterke invloed uit op het verloop van mijn ziekte.

3. Dat ik ziek ben geworden komt deels doordat

God dat zo heeft beschikt.

9. God oefent een sterke invloed uit op het verloop van mijn ziekte.

16. Mijn geloof heeft invloed op het verloop van mijn ziekte.

18. Dat ik ziek ben geworden heeft te maken met mijn karakter.

21. Dat ik ziek geworden ben ligt voornamelijk aan mezelf.

6. Dat ik ziek ben geworden heeft te maken met mijn leefpatroon.

12. Dat ik ziek ben geworden is gedeeltelijk mijn schuld.

11. Dat ik ziek ben geworden is vooral veroorzaakt door vervuiling van het leefmilieu.

15. Ingrijpende gebeurtenissen in mijn leven hebben ertoe bijgedragen dat ik ziek ben geworden.

1. Dat ik ziek ben geworden is zonder twijfel een een kwestie van toeval.

10. Het zijn vooral de medische behandelingen

die het verloop van mijn ziekte bepalen.

8 . Hoe mijn ziekte zal verlopen wordt vooral door het toeval bepaald.

13. Door het Moerman dieet kan ik het verloop van ziekte verbeteren.

- Items die door Pruyn e.a. zijn gebruikt om de somscores op de dimensies te berekenen. 
BLJLAGE E: Samenhang tussen beheersingsoriëntatie en kwaliteit van leven

Samenhang tussen de beheersingsoriëntatie en kwaliteit van leven op t1 en t3. Pearson correlaties $(n=50)$

$\mathrm{t} 1$

t3

interne oriëntatie

$-.10$

$-.04$

ontstaan

religieuze oriëntatie

.06

.06

beïnvloedbaarheid

verloop

.09

$-.00$

Samenhang beheersingsoriëntatie en het beloop van kwaliteit van leven t-test ( $n=50$ ).

$\begin{array}{ll}\text { achteruit/gelijk } & \text { vooruit } \\ (n=25) & (n=25)\end{array}$

\begin{tabular}{lrrrrr}
\hline & gem & s.d. & gem & s.d & \\
interne oriëntatie & 4.1 & 1.5 & 3.8 & 1.5 & n.s \\
ontstaan & 6.5 & 3.5 & 7.4 & 3.1 & n.s \\
religieuze oriëntatie & 18.9 & 4.4 & 18.4 & 4.4 & n.s \\
beïnvloedbaarheid verloop & 18.9 & & & & \\
\hline
\end{tabular}


BLJLAGE F: Professionele zorgverleners op de drie meetmomenten. Noord-Limburg $(n=51)$ en Maastricht $(n=16)$.

\begin{tabular}{|c|c|c|c|c|c|c|}
\hline & \multicolumn{3}{|c|}{ Noord-Limburg $(n=51)$} & \multicolumn{3}{|c|}{ Maastricht $(n=16)$} \\
\hline & $\mathrm{t} 1$ & t2 & $\mathrm{t} 3$ & $\mathrm{t} 1$ & t2 & t3 \\
\hline special & $50(98 \%)$ & $48(94 \%)$ & $46(90 \%)$ & $16(100 \%)$ & $16(100 \%)$ & $15(94 \%)$ \\
\hline hsarts & $50(98 \%)$ & $41(80 \%)$ & $35(69 \%)$ & $9(56 \%)$ & $9(56 \%)$ & $9(56 \%)$ \\
\hline a.assis. & $41(80 \%)$ & $10(20 \%)$ & - & $4(25 \%)$ & $2(13 \%)$ & - \\
\hline zhverpl & $43(84 \%)$ & $6(12 \%)$ & $2(4 \%)$ & $3(14 \%)$ & - & - \\
\hline radioth & $21(41 \%)$ & $8(16 \%)$ & $7(14 \%)$ & $6(38 \%)$ & $6(38 \%)$ & $5(31 \%)$ \\
\hline wijkvk. & $14(27 \%)$ & $11(22 \%)$ & $6(12 \%)$ & - & - & \\
\hline fysioth & $8(16 \%)$ & $6(12 \%)$ & $7(14 \%)$ & $1(6 \%)$ & $1(6 \%)$ & $2(13 \%)$ \\
\hline pastor & $23(45 \%)$ & $2(4 \%)$ & $3(6 \%)$ & $4(25 \%)$ & $2(13 \%)$ & $2(13 \%)$ \\
\hline gezinsz & $9(18 \%)$ & $5(10 \%)$ & $4(8 \%)$ & $2(13 \%)$ & $2(13 \%)$ & $1 \quad(6 \%)$ \\
\hline alt.gen & $4(8 \%)$ & $6(12 \%)$ & $8(16 \%)$ & $5(31 \%)$ & $4(25 \%)$ & $2(13 \%)$ \\
\hline psychol & - & - & - & $2(13 \%)$ & - & - \\
\hline maatscw & $2(4 \%)$ & - & & & $1(6 \%)$ & - \\
\hline
\end{tabular}

Gemiddelde contactfrequentie met betrokken zorgverleners.

Noord-Limburg (wisselende n, zie boven)

$\begin{array}{llll} & \mathrm{t} 1 & \mathrm{t} 2 & \mathrm{t} 3 \\ \text { special } & 6.7 & 2.2 & 1.8 \\ \text { hsarts } & 5.1 & 4.3 & 3.8 \\ \text { a.assis. } & 12.9 & 5.2 & - \\ \text { zhverpl } & 15.5 & 10.3 & 4.0 \\ \text { radioth } & 6.3 & 1.8 & 1.1 \\ \text { wijkvk. } & 5.2 & 5.2 & 12.3 \\ \text { fysioth } & 10.5 & 20.0 & 14.9 \\ \text { pastor } & 2.7 & 0.5 & 1.7 \\ \text { gezinsz } & 10.4 & 12.6 & 11.2 \\ \text { alt.gen } & 2.1 & 2.8 & 2.5 \\ \text { psychol. } & - & - & - \\ \text { maatsc } & 2 & - & -\end{array}$

Maastricht (wisselende $n$, zie boven)

t1 t2

$\begin{array}{lll}5.0 & 2.4 & 1.7 \\ 2.7 & 2.2 & 2.4 \\ 10.8 & 1.5 & - \\ 13.3 & - & - \\ 4.3 & 3.5 & 1.4 \\ - & - & - \\ 36.0 & 36.0 & 22.0 \\ 1.8 & .50 & 1.0 \\ 48.0 & 15.0 & 48.0 \\ 3.2 & 1.9 & 1.5 \\ 1.0 & - & - \\ - & 1 & -\end{array}$


BLJLAGE G: Overeenstemming met betrekking tot zorgbehoeften, tussen patienten en centrale verzorgers, huisartsen en specialisten

$(n=48)$.

\begin{tabular}{|c|c|c|c|}
\hline kappa & kmax & $\begin{array}{l}\text { aantal } \\
\text { malen } \\
\text { overeen- } \\
\text { stemming }\end{array}$ & $\begin{array}{l}\text { inschatting } \\
\text { zorgverlener } \\
\text { hoger/laget dan } \\
\text { patient }\end{array}$ \\
\hline
\end{tabular}

A.D.L

t 1

cv - pat $(n=43)$

ha - pat $(n=48)$

sp - pat $(n=34)$

t 3

cv - pat $(n=42)$

ha - pat $(n=45)$

$\begin{array}{lll}1.0 & 1.0 & 43100 \%\end{array}$

$0.49 \quad 0.49 \quad 4696 \%$

$0.00 \quad 0.00 \quad 2779 \%$

2 lager

1 lager

6

$\begin{array}{llll}0.84 & 0.84 & 4198 \% & 1 \text { lager }\end{array}$

$0.39 \quad 0.73 \quad 4193 \% \quad 3$ tager

1

H.D.L

t 1

cv - pat $(n=43)$

$0.62 \quad 1.00 \quad 3581 \%$

$0.28 \quad 0.38 \quad 3061 \%$

$0.00 \quad 0.00 \quad 1338 \%$

4 hoger/4 lager

1 hoger/14 lager

12 lager

9

sp - pat $(n=34)$

$0.48 \quad 0.90 \quad 3176 \%$

6 hoger $/ 4$ lager

$0.19 \quad 0.42 \quad 2760 \% \quad 2$ hoger/12 lager

4

Medicijn

11

cv - pat $(n=43)$

$0.35 \quad 0.78 \quad 4093 \%$

$0.30 \quad 0.65 \quad 4492 \%$

$0.00 \quad 0.00 \quad 2779 \%$

2 hoger/1 lager

2 hoger/2 lager

3 lager

4

t 3

$1.00 \quad 1.00 \quad 42100 \%$

$0.15 \quad 0.63 \quad 3782 \% \quad 2$ hoger/5 lager

1

Oefeningen

t 1

cv - pat $\{n=43$ )

0.35

$0.78 \quad 4093 \%$

$0.23 \quad 0.85 \quad 4289 \%$

1 hoger/2 lager

3 hoger/2 lager

1 noger/2 lager

6

sp - pat $(n=34$

0.03

$0.66 \quad 2574 \%$

3 hoger/1 lager

$0.45 \quad 0.73 \quad 3890 \%$

$0.65 \quad 0.65 \quad 4293 \%$

2 lager

1

Ziekteverwerking

t 1

cv - pat $(n=43)$

ha - pat $(n=48)$

$\begin{array}{lll}0.33 & 0.44 \quad 3070 \%\end{array}$

$0.04 \quad 0.67 \quad 2450 \%$

sp - pat $(n=34)$

0.25

$0.251441 \%$

11 hoger/2 lager

14 hoger/7 lager

4 hoger

3

13

$0.08 \quad 0.57 \quad 2764 \%$

11 hoger/4 lager

$0.48 \quad 0.92 \quad 3067 \%$

4 hoger /3 lager 


\begin{tabular}{|c|c|c|c|c|c|c|c|c|c|c|c|}
\hline & zrg & chs & zspe & bez & cha & laak & ovh & ovcr & $g t$ & teh & tes \\
\hline $\mathrm{zrg}$ & 1.0 & & & & & & & & & & \\
\hline chs & -.15 & 1.0 & & & & & & & & & \\
\hline zspe &.$\infty$ & .06 & 1.0 & & & & & & & & \\
\hline bez & .16 & -.15 & $-.23 *$ & 1.0 & & & & & & & \\
\hline cha & .14 & -.03 & .05 & $.22^{*}$ & 1.0 & & & & & & \\
\hline taak & -.09 & .08 & .19 & .01 & .12 & 1.0 & & & & & \\
\hline ovh & -.21 & -.01 & -.08 & -.17 & .06 & .14 & 1.0 & & & & \\
\hline ovcr & -.02 & .07 & .21 & $-.26^{*}$ & .17 & -.02 & .13 & 1.0 & & & \\
\hline$g t$ & -.01 & .12 & $.49 * *$ & $-.25 *$ & $.28 *$ & .18 & .04 & .23 & 1.0 & & \\
\hline teh & -.14 & -.03 & -.05 & .03 & $.25 *$ & .19 & .21 & .03 & $.26 *$ & 1.0 & \\
\hline tes & $.25^{*}$ & -.08 & .21 & -.14 & .14 & .02 & -.05 & $.28^{*}$ & $.54 * *$ & $.26^{*}$ & 1.0 \\
\hline
\end{tabular}

derde meting $(\mathbf{n}=51)$

zrg chs zspe cha taak ovh ovcr gt teh tes

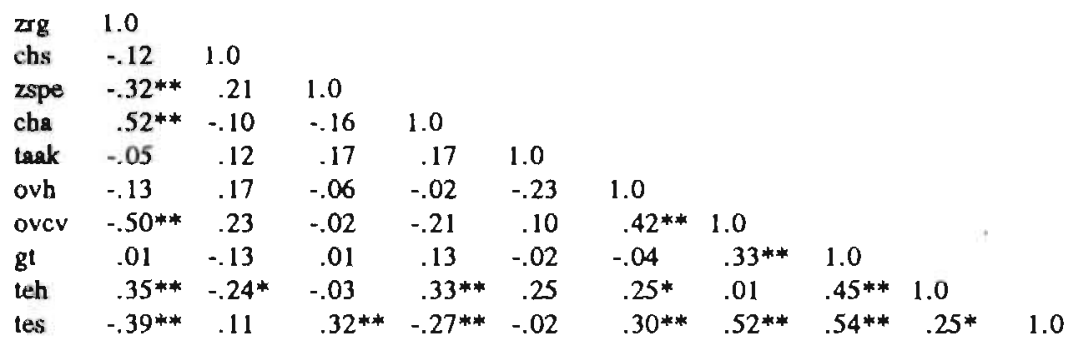

$* \mathrm{p}<0.10, * \mathrm{p}<0.05$

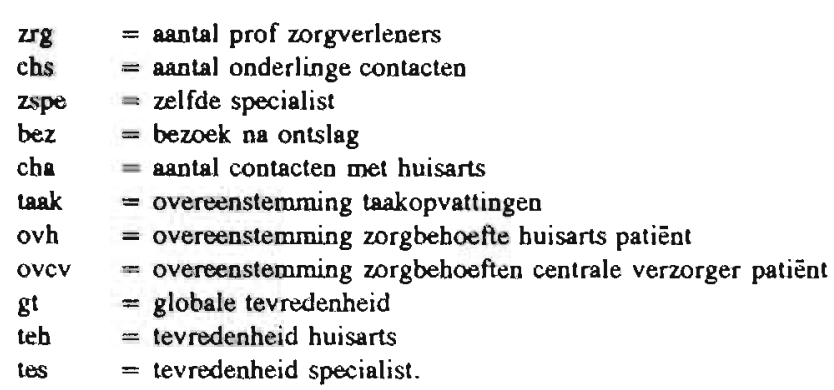




\section{Eerste meting}

$\begin{array}{lccccccc} & \begin{array}{c}\text { zrg } \\ \text { zrg }\end{array} & \text { chs } & \text { zspe } & \text { bez } & \text { taak } & \text { ovh } & \text { tevr } \\ \text { chs } & -.15 & 1.0 & & & & & \\ \text { spe } & .00 & .06 & 1.0 & & & & \\ \text { bez@ } & .16 & -.15 & -.23 * & 1.0 & & & \\ \text { taak@ } & -.09 & .08 & .17 & .01 & 1.0 & & \\ \text { ovh } & -.21 & -.01 & -.08 & -.17 & .14 & 1.0 & \\ \text { tevr } & .06 & -.01 & .27 * & -.15 & .17 & .08 & 1.0\end{array}$

Derde meting

$\begin{array}{lllllll} & \begin{array}{c}\mathrm{zrg} \\ \mathrm{zrg}\end{array} & \mathrm{chs} & \text { spe } & \text { taak } & \text { ovh } & \text { tevr } \\ \text { chs } & -.12 & 1.0 & & & & \\ \text { spe } & -.32^{* *} & .21 & 1.0 & & & \\ \text { taak@ } & -.05 & .12 & .19 & 1.0 & & \\ \text { ovh } & -.13 & .17 & -.06 & -.23 & 1.0 & \\ \text { tevr } & -.03 & .05 & .15 & .09 & .25^{*} & 1.0\end{array}$

$* \mathrm{p}<0.10, * * \mathrm{p}<0.05$

(1) alleen eerste meting beschikbaar

$\begin{array}{ll}\text { zrg } & =\text { aantal prof zorgverleners } \\ \text { chs } & =\text { contact tussen huisarts en specialist } \\ \text { spe } & =\text { zelfde specialist } \\ \text { taak } & =\text { overeenstemming taakopvattingen } \\ \text { ovh } & =\text { overeenstemming zorgbehoefte huisarts patiënt } \\ \text { bez } & =\text { bezoek na ontslag } \\ \text { tevr } & =\text { tevredenheid over de zorgverlening }\end{array}$


eerste meting

\begin{tabular}{|c|c|c|c|c|c|c|c|}
\hline & grt & pfam & dicht & erno & pra & wedern & wedpr \\
\hline grt & 1.0 & & & & & & \\
\hline pfam & -.10 & 1.0 & & & & & \\
\hline dicht & $-.29 * *$ & $.25^{*}$ & 1.0 & & & & \\
\hline emo & $-.25^{*}$ & .04 & $.25 *$ & 1.0 & & & \\
\hline pra & $-.49 * *$ & .04 & .21 & $.35^{* *}$ & 1.0 & & \\
\hline wedem & -.03 & .17 & .05 & $-.35 * *$ & -.06 & 1.0 & \\
\hline wedpr & .11 & $.27 * *$ & *. .02 & -.14 & $-.60 * *$ & .17 & 1.0 \\
\hline
\end{tabular}

derde meting

grt pfam dicht emo pra wedem wedpr

grt $\quad 1.0$

pfam $\quad-.07 \quad 1.0$

dicht $\quad-.28 * * 23 * 1.0$

$\begin{array}{lllll}\text { ermo } & -.26 * & .07 & .21 & 1.0\end{array}$

pra $\quad-.27 * * .15 \quad .41^{* *} \quad .49 * * 1.0$

wedem $\quad .25 * \quad .00 \quad-.17 \quad-.53 * * \quad-.24 * \quad 1.0$

$\begin{array}{lllllllll}\text { wedpr } & .04 & .02 & -.20 & -.25 * & -.67 * * & .19 & 1.0\end{array}$

${ }^{*} \mathrm{p}<0.10,{ }^{* *} \mathrm{p}<0.05$

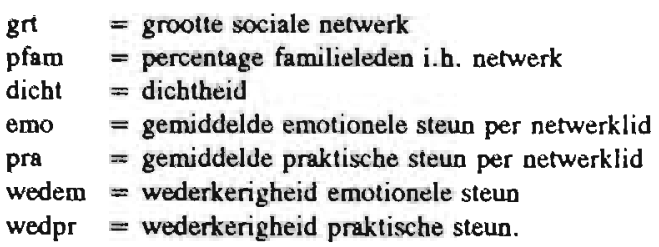


BLJLAGE K: Discriminantanalyses m.b.t. het beloop van kwaliteit van leven, eerste en derde meting. Noord-Limburg $(n=51)$

Eerste meting

verklarende variabelen gest. dis.functie coëff. binnen-groeps structuurcoeff.

ernst van de ziekte

leeftijd

.01

aantal prof.zorgverleners $\mathrm{t} 1$

$.66 \quad .40$

$.66 \quad .38$

takovereenstemming

tevredenheid zorg $\mathrm{tl}$

$.72 \quad .53$

overeenstemming zorgbehoeften $\mathrm{tl} \quad-.09$

emotionele steun $\mathrm{t} 1$

praktische steun $t 1$

-.13
-.39
-.27

can. correlatie $=.57$, eigenwaarde $=.47$, juist geclassificeerd $=78 \%$

Derde meting

verklarende variabelen

gest. dis. functie coëff. binnen-groeps structuurcoëff.

ernst van de ziekte

$-.16$

leeftijd

.57

.49

aantal prof.zorgverleners $t 3$

$-.17$

tevredenheid zorg $\mathrm{t} 3$

.72

.65

overeenstemming zorgbehoefte $t 3$

.16

emotionele steun $t 3$

$-.61$

$-.42$

praktische steun $\mathrm{t} 3$

$-.06$

can. correlatie $=.51$, eigenwaarde $=.35$, juist geclassificeerd $=78 \%$ 
. 


\section{Dankwoord}

Aan dit onderzoek werkten patiënten, centrale verzorgers, huisartsen, specialisten en verpleegkundigen mee. Hun bijdrage bestond uit het meermalen deelnemen aan interviews en het invullen van enquêtes. Zonder hun medewerking zou dit verslag nooit geschreven zijn. Daarnaast vormden vele anderen een bron van hulp bij het tot stand komen van dit proefschrift.

Om te beginnen is dat mijn promotor Prof. dr. Hans Philipsen. Hans, mijn oprechte dank voor je geduldige en inspirerende begeleiding. Jouw heldere kijk op het onderzoek maakte dat we er bij problemen steeds weer uit kwamen. Ik heb veel van je geleerd.

Mijn co-promotor Dr. Fred Stevens wil ik danken voor het meedenken en zijn adviezen gedurende het hele traject.

Promotor Prof. dr. Harry Crebolder en co-promotor Dr. Remy van der Grinten ben ik zeer erkentelijk voor hun hulp bij de dataverzameling in Noord-Limburg en de nauwgezetheid waarmee ze het manuscript steeds hebben gelezen.

Een bijzonder woord van dank ben ik verschuldigd aan Dr. L. de Witte. Luc, veel dank voor het steeds meedenken, het nauwkeurig lezen en het samen doorploeteren van de vele 'uitdraaien'. Je stond altijd voor mij klaar, ook buiten gewone werktijden. Elk beginnend onderzoeker zou zich zo'n begeleider wensen.

De leden van de 'projectgroep', bestaande uit medewerkers van het azM, het I.K.L., de provinciale kruisvereniging, de vakgroep verplegingswetenschap en het Withuis dank ik voor hun adviezen in de beginfase van het project.

Het onderzoek was zeer veldintensief. De patholoog van het St.Maartens Gasthuis en de specialisten van het azM hebben geholpen bij de selectie van de patiënten. Hiervoor mijn dank. Zonder het nimmer aflatende enthousiasme van de interviewers hadden we de dataverzameling niet in dit tijdsbestek afgekregen. Marijke Claessens, Truus Kusters, Marly Schlooz, Wim Elferink, Tiny Engelhard, Neeltje Mosterd en Mevrouw Meerts, veel dank voor het afnemen van de vraaggesprekken. Vonca Schaffers wil ik danken voor het uittypen van de interviewteksten.

Bij de vakgroep medische sociologie vormden enkele mensen een nimmer aflatende bron van steun, zowel op emotioneel als op praktisch vlak. Mijn vrienden Ate en Theo waren er gewoon altijd. Het plezier dat we samen hebben gehad vormde een welkome afwisseling voor het serieuze werk.

Ton Hameleers heeft in de slotfase het manuscript op tekstuele fouten nagekeken, daank uuch. Paul Lucassen was zo vriendelijk om mij te helpen bij de summary. Hiervoor mijn dank.

Als besluit wil ik twee personen uit mijn primaire netwerk bedanken. Mijn moeder, omdat zij mij altijd gestimuleerd heeft in mijn studie en werk.

Tenslotte ben ik de meeste dank verschuldigd aan Harrie. Getrouwd zijn met een promovenda is niet gemakkelijk. Je liet echter nooit na mij te stimuleren om door te gaan. Je optimisme en relativerende opmerkingen deden vaak wonderen. 


\section{Curriculum Vitae}

Annemie Courtens werd op 3 februari 1962, in Maastricht geboren. Ze volgde haar VWO-opleiding aan het Stedelijk Lyceum te Maastricht, waar zij in 1980 het eindexamen Atheneum-A behaalde. Van 1980 tot 1984 studeerde zij verpleegkunde aan de H.B.O.-V., Gezondheidszorgacademie, te Sittard. In 1984 begon zij aan de Rijksuniversiteit Limburg met de studie Gezondheidswetenschappen. De studie combineerde zij met werkzaamheden als verpleegkundige bij het psycho-medisch streekcentrum Vijverdal, te Maastricht. In 1987 behaalde ze het doctoraal examen met als afstudeerrichting verplegingswetenschap.

Vanaf oktober 1987 werd zij aangesteld als a.i.o bij de faculteit der geneeskunde, vakgroep medische sociologie, Rijksuniversiteit Limburg. Van oktober 1991 tot mei 1992 werkte zij bij deze vakgroep als 'vrijwilliger' verder aan haar proefschrift.

In de periode van december 1991 tot mei 1992 was zij werkzaam als docent verpleegkunde aan de Hogeschool te Sittard.

Sinds mei 1992 werkt zij part-time als universitair docent bij de vakgroep verplegingswetenschap en part-time als staffunctionaris bij het stafburo zorgmanagement in het Academisch Ziekenhuis Maastricht. 
DATAWYSE I Universitaire Pers Maastricht ISBN 9052780625

NUGI $756 / 735$ 